\title{
An Indirect Route for Ethanol Production
}

Submitted to:

U.S. Department of Energy

Office of Industrial Technologies

Inventions and Innovation Program

Grant: DE-FG36-03G013010

April 29, 2005

by

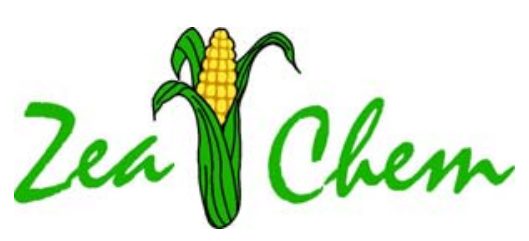

ZeaChem Inc.

$2319 \mathrm{~S}$. Ellis Ct.

Lakewood, CO 80228

Principal Investigator: Tim Eggeman, Ph.D., P.E.

Phone: 303-358-6390

E-mail: time@zeachem.com

Dan Verser, Ph.D.

Phone: $303-489-7480$

E-mail: danver@zeachem.com

Eric Weber, Ph.D.

Phone: 970-218-6269 


\section{Executive Summary}

The ZeaChem indirect method is a radically new approach to producing fuel ethanol from renewable resources. Sugar and syngas processing platforms are combined in a novel way that allows all fractions of biomass feedstocks (e.g. carbohydrates, lignins, etc.) to contribute their energy directly into the ethanol product via fermentation and hydrogen based chemical process technologies.

The goals of this project were: 1) Collect engineering data necessary for scale-up of the indirect route for ethanol production, and 2) Produce process and economic models to guide the development effort. Both goals were successfully accomplished.

The projected economics of the Base Case developed in this work are comparable to today's corn based ethanol technology. Sensitivity analysis shows that significant improvements in economics for the indirect route would result if a biomass feedstock rather that starch hydrolyzate were used as the carbohydrate source.

The energy ratio, defined as the ratio of green energy produced divided by the amount of fossil energy consumed, is projected to be 3.11 to 12.32 for the indirect route depending upon the details of implementation. Conventional technology has an energy ratio of 1.34, thus the indirect route will have a significant environmental advantage over today's technology. Energy savings of 7.48 trillion Btu/yr will result when $100 \mathrm{MMgal} / \mathrm{yr}$ (neat) of ethanol capacity via the indirect route is placed on-line by the year 2010 . 


\section{Table of Contents}

Executive Summary $\quad$ i

$\begin{array}{ll}\text { Project Description } & 1\end{array}$

Project Goals and Objectives

Tasks

Task 1 - Fermentation Step

Background

Methods and Materials

Results

Discussion

Sub-Task Review

References

Figures and Tables

Task 2 - Esterification Step

Background

Methods and Materials

Results

Discussion

Sub-Task Review

References

Figures and Tables

Task 3 - Modeling

Process Model

Economic Model

Energy Savings Metrics

Sub-Task Review

References

Figures and Tables

Task 4 - Reporting

Sub-Task Review 
Appendices

Appendix A Final Task Schedule

Appendix B Final Spending Schedule $\quad 70$

Appendix C Final Cost Share Contributions $\quad 71$

Appendix D Energy Savings Metrics

Supplemental Information

Appendix E Detailed Description of Base Case Process Model 


\section{Project Description}

Existing technologies for fuel ethanol production all rely on direct fermentation of carbohydrates derived from corn, sugar cane and other sources. All direct fermentation routes suffer from low carbon efficiency. For example, when the fermentable sugar is dextrose:

\section{Direct Fermentation:}

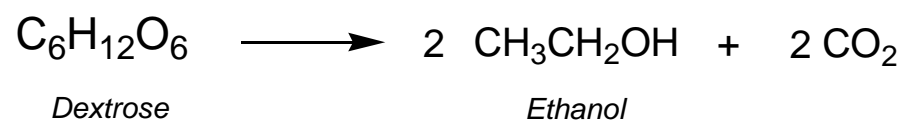

two of the six carbon atoms in the substrate are converted into carbon dioxide, giving a maximum carbon efficiency of only 67\%. From a chemical energy perspective, direct fermentation is actually quite efficient. The ratio of higher heating values for ethanol and dextrose is $(2 \times 1369 \mathrm{~kJ} / \mathrm{mol}) /(2807 \mathrm{~kJ} / \mathrm{mol}) * 100=98 \%$, which means that most of the chemical energy stored in the starting dextrose is preserved in the final product. However, throwing away carbon in the form of $\mathrm{CO}_{2}$ restricts the ability of direct fermentation processes to derive chemical energy from sources other than fermentable carbohydrates.

What are the consequences of this limitation? Consider processing a typical lignocellulosic biomass such as corn stover into ethanol. Roughly one-third of the energy content of the feed is present in the form of cellulose, which can be converted into dextrose with appropriate pretreatment and hydrolysis of the feedstock and then fermented with traditional direct fermentation yeasts or similar micro-organisms. Lignin and other non-fermentable materials account for approximately $40 \%$ of the energy content of the feedstock. None of this energy can be used directly for ethanol production; it can only be burned and the heat released used to generate steam and power for the plant. The balance of the feedstock is in the form of hemicellulose, which produces a mixture of five and six carbon sugars upon pretreatment and hydrolysis of the biomass feedstock. Genetically engineered micro-organisms that produce ethanol from both five and six carbon sugars must be utilized to obtain high yield from the hemicellulose derived sugars since no wild type micro-organisms exist that are capable of converting mixed sugars. Thus $40-60 \%$ of the chemical energy of the starting material (i.e. all of the lignin plus any unfermented materials from the cellulose and hemicellulose fractions of the biomass) is not available for ethanol production via direct fermentation. Designs for lignocellulosic based ethanol plants are usually net exporters of electrical power because of inherent limitations of their process chemistry.

The ZeaChem indirect method is a radically new approach to producing fuel ethanol from renewable resources. Sugar and syngas processing platforms are combined in a novel way to preserve carbohydrate carbon in the ethanol product, allowing lignin and other non-fermented fractions to contribute their energy directly into the ethanol product via hydrogen based chemical process technologies. Our core chemistry can be broken down into three steps, as illustrated for the case of dextrose as the fermentable carbohydrate: 


\section{Indirect Ethanol Production Route}

Fermentation:

Esterification:

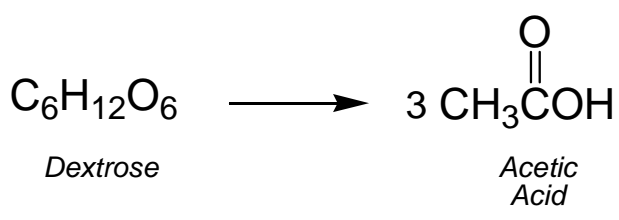

$3 \mathrm{CH}$

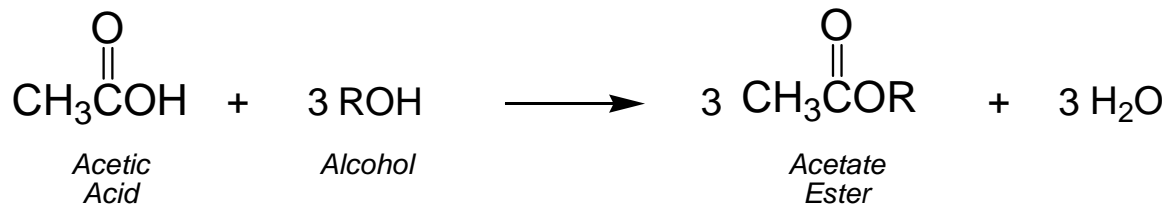

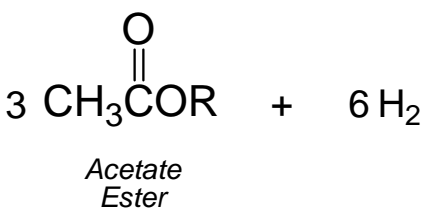

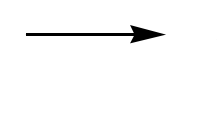
$3 \mathrm{CH}_{3} \mathrm{CH}_{2} \mathrm{OH}+3 \mathrm{ROH}$
Ethanol
Alcohol

In the first step, a homoacetogenic fermentation is used to produce acetic acid from carbohydrates at near $100 \%$ carbon yield. The homoacetogens are well studied micro-organisms and many wild-type strains are known to ferment both five and six carbon sugars. In the second step, the acetic acid is esterified with an alcohol to produce an ester. Esterification is a widely practiced chemical process technology. For example, Eastman Chemical produces over $400 \mathrm{MM}$ $\mathrm{lb} / \mathrm{yr}$ of methyl acetate using methanol and acetic acid as feedstocks. In the third step, the ester undergoes hydrogenoloysis to produce the desired ethanol product and the recycle alcohol for the esterification step. Like esterification, hydrogenolysis of esters is a well-known chemical process technology. For example, the majority of new plants built in the last twenty years for the production of 1,4-butanediol (a monomer used mostly in automotive plastics) utilized a route based on the hydrogenolysis of dimethyl maleate or a similar ester.

The net result of the indirect route for ethanol production is a 50\% improvement in molar yield compared to conventional direct fermentation technologies (i.e. 3 moles of ethanol per mole of six carbon sugar versus 2 moles ethanol per mole of six carbon sugar). The energy for the third mole of ethanol is supplied by hydrogen. Biomass gasification is a particularly attractive means of hydrogen production since it converts the chemical energy stored in lignin 
and other non-fermentables into hydrogen, which in turn can be converted into the chemical energy stored in the ethanol product. This, combined with the fact that many homoacetogens metabolize both five and six carbon sugars, means that the chemical energy of all three major biomass fractions can be converted into ethanol at high overall energy efficiency with the indirect route.

\section{Project Goals and Objectives}

The goal of this project is to collect engineering data necessary for scale-up of the indirect route for ethanol production. A significant portion of this grant was spent on laboratory scale experiments necessary to support scale-up to pilot operations. By necessity, the scope of the project was narrowed to consider a specific application: integration of the indirect ethanol route with an existing corn wet milling facility, though much of what was learned is directly transferable to other potential applications such as corn dry milling, sugar cane processing and lignocellulosic feedstock facilities.

Figure 1 is a simplified block flow diagram for the base case considered in this grant. A portion of the starch hydrolyzate and light steep water streams from an existing corn wet mill are used as carbohydrate and nutrient sources for the fermentation step. The acetate is recovered from the broth and an acetate ester is produced by esterification with the recycle alcohol. This ester then undergoes hydrogenolysis to produce the desired ethanol product plus the recycle alcohol. Hydrogen is provided by gasification of corn stover. A portion of the syngas produced by the gasifier is diverted to the cogeneration unit to produce steam and power.

The experimental program was limited to work on the fermentation and recovery sections of the proposed flowsheet. Modeling efforts cover all of the units shown in Figure 1 except for the corn wet mill. Development of a detailed process and economic model for a corn wet milling operation was placed outside the scope of work. Starch hydrolyzate and light steep water are assumed to be supplied to the ethanol facility at a negotiated transfer price.

\section{Tasks}

Task 1 is the experimental program for the fermentation step. A homoacetogenic bacteria strain was adapted to use glucose as the main carbon and energy source and light steep water as the main nutrient source. Performance of the adapted strain was compared with performance on a traditional yeast extract based media. No strain selection or other media development work was included in the scope of work for this task.

Task 2 is the experimental program for the esterification recovery step. The sub-tasks are concerned with the details of acidification via formation of the amine complex with concurrent precipitation of calcium carbonate, extraction of the amine complex from aqueous solution, and formation of the ester directly from the extract.

Task 3 is the computer modeling task. A process model was generated for the indirect route represented in Figure 1. Results from the process model were used to support the energy 
savings metrics given in Appendix D. The economic model, derived from the process model, was used to make economic projections for the indirect route.

Task 4 covers the reporting requirements for the grant.

To simplify presentation, the report is divided into stand-alone sections for each task. Reference lists, supporting figures and tables, etc. for each task are presented at the end of each section. 


\section{Figure 1 - Base Case Block Flow Diagram}

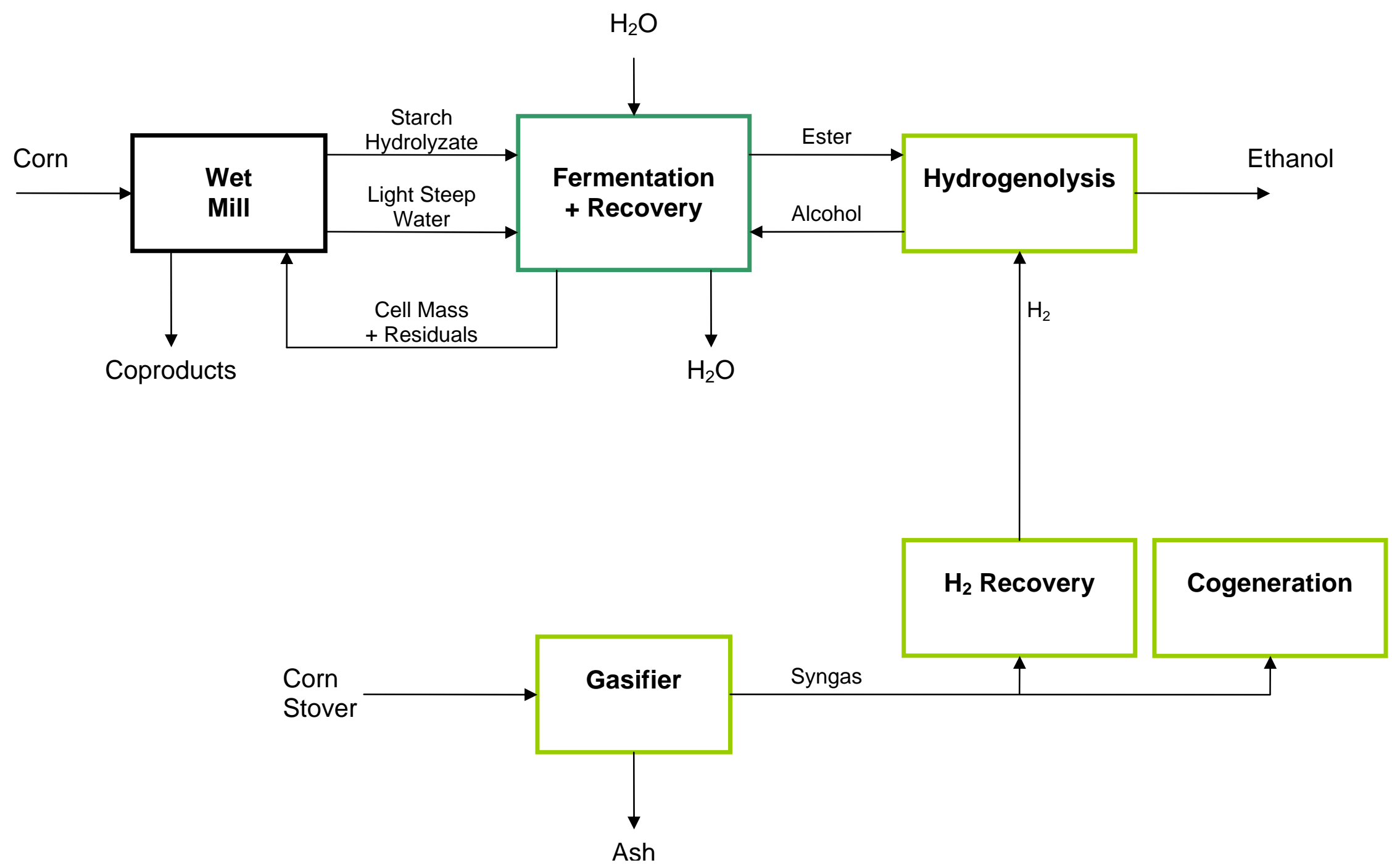




\section{Task 1 - Fermentation Step}

\section{Background}

Acetogens and methanogens are two types of bacteria capable of fixing carbon dioxide and incorporating it into either cell mass or potentially useful primary metabolic products. Our interest lies with the acetogens, and more specifically with the homoacetogens. Drake (1) defines the acetogens as follows:

Acetogens are obligately anaerobic bacteria that can use the acetyl-CoA pathway as their predominant:

(i) mechanism for the reductive synthesis of acetyl-CoA from $\mathrm{CO}_{2}$,

(ii) terminal electron-accepting, energy-conserving process, and

(iii) mechanism for the synthesis of cell carbon from $\mathrm{CO}_{2}$.

Homoacetogens are acetogens that form acetate as the major reduced metabolic product.

Homoacetogens have found competitive niches in many anaerobic environments such as freshwater and marine sediments, deep subsurface sediments associated with oil fields, sewers, anaerobic digesters, and the gastrointestinal tracts of termites, cockroaches, ruminants, and monogastric animals including humans. The acetate produced by the acetogen is a key intermediate in these environments. It is often utilized directly as an energy source by the host animal or further converted into methane by methanogenic bacteria.

Acetogens compete in these environments because of the remarkably diverse range of substrates they consume. Sugars (both six carbon sugars like glucose, and five carbon sugars like xylose), carbon monoxide, $\mathrm{H}_{2} / \mathrm{CO}_{2}$ mixtures, alcohols (methanol, ethanol, 2,3-butanediol, glycerol), organic acids (formate, lactate, citrate, malate), and lignin breakdown products (methoxylated aromatics, syringate, vanillate) are among the substrates frequently metabolized.

Figure 1.1a is a simplified sketch of the pathways used by homoacetogenic bacteria for the catabolism of glucose and lactate. Glucose is converted to pyruvate using the EmbdenMeyerhof glycolytic pathway. Lactic acid is also metabolized by first converting it back to pyruvate. Pyruvate is decarboxylated and then oxidized to acetate with the concurrent production of ATP. The main distinguishing feature of acetogenic bacteria is that $\mathrm{CO}_{2}$, either from the $\mathrm{CO}_{2}$ released in the decarboxylation step or from the environment, is fixed via the acetyl-CoA pathway and is used to produce an additional mole of acetic acid. In contrast, nonacetogenic micro-organisms that produce acetic acid are only capable of producing a maximum of two moles of acetate per mole of glucose consumed

Figure $1.1 \mathrm{~b}$ is a simplified sketch of the pentose phosphate pathway used by acetogens to metabolize five carbon sugars such as xylose. The skeletons of the five carbon sugars are rearranged into either three or six carbon sugar intermediates which are then fed to glycolysis and further converted into acetate as shown previously in Figure 1.1a. Mixotrophic growth (i.e. the concurrent consumption of two or more substrates) among acetogens is common. This feature is 
particularly important when considering fermentation of mixed sugar substrates such as lignocellulose hydrolyzates.

The potential for very high carbon utilization is the driving force behind much of the interest in acetogenic metabolism. The net stoichiometry for the three substrates shown in Figure 1.1 is:

$$
\begin{gathered}
\text { Glucose } \rightarrow 3 \text { Acetic Acid } \\
2 \text { Lactic Acid } \rightarrow \text { 3Acetic Acid } \\
3 \text { Xylose } \rightarrow 5 \text { Acetic Acid }
\end{gathered}
$$

Notice in all three reactions there is no net production of carbon dioxide. All of the feedstock carbon is converted into acetate. Ignoring the effects of cell mass production, homoacetogens are capable of converting these substrates into acetic acid at 100\% theoretical mass yield. In practice, fermentation yields have exceeded $85 \%$ in many studies.

The acetogenic bacteria include members in the Clostridium, Acetobacterium, Peptostreptococcus, Sporomusa and a couple of other lesser known species. Drake (1) lists at least 60 strains of homoacetogens. Many of the homoacetogens were originally classified in the genus Clostridium. However, the genus Clostridium has recently been reorganized based on modern genetic understanding and many acetogens have been renamed (2).

By far the most work to date has been done with Moorella thermoacetica, formerly Clostridium thermoaceticum. M. thermacetica is a gram variable, spore forming, thermophilic homoacetogen originally isolated from horse manure. $M$. thermoacetica has a temperature growth optimum around $58{ }^{\circ} \mathrm{C}$ and an optimal $\mathrm{pH}$ for growth around 7.0 (see Figure 1.2). This acetogen is sensitive to product inhibition and requires a low redox potential for growth. Maximum acetate tolerance for growth is about 30-50 g/l in batch fermentation. Typically, a reduced medium is prepared by including a reducing agent in the formulation (e.g. $\mathrm{Na}_{2} \mathrm{~S}$, $\mathrm{Na}_{2} \mathrm{SO}_{3}$, cystiene, or thioglycolate) and purging the medium of all oxygen by using an inert gas. Although the acetogens are classified as strict or obligate anaerobes, previous work shows some oxygen tolerance and that many strains are capable of lowering the redox potential of their medium once growth is initiated (4).

Several kinetic studies have been conducted to examine the effects of $\mathrm{pH}$ and acetate levels on both cell growth and acid production for $M$. thermoacetica and related homoacetogens (5-9). In general, these studies have shown that acetate production is mostly growth associated, with a relatively small amount of acetate production occurring during cell maintenance. Quite a bit of work has focused on the development of low $\mathrm{pH}$ tolerant acetogens, perhaps best illustrated by the work at Union Carbide and later at CPC International (10-13). These researchers used classical mutagenesis and selection techniques to obtain an isolate of $M$. thermoacetica capable of growth at $\mathrm{pH}$ 4.5. However, growth completely ceased at acetate levels above $2.2 \mathrm{~g} / \mathrm{l}$ (as acetate). In contrast, Wang and Wang (6) showed that $M$. thermoacetica is capable of growth at $\mathrm{pH} 7$ at acetate levels up to $45 \mathrm{~g} / \mathrm{l}$ (as acetate). These results suggest that industrially useful final concentrations of acetate in the fermentation broth can only be obtained at near neutral $\mathrm{pH}$ with the current state of the art, although it does not exclude the possible 
future development of an acid tolerant acetogen. More advanced genetic engineering methods may prove to be more useful should future work be pursued along these lines.

The literature is replete with experimental trials of acetogenic fermentations with various fermentor configurations. Batch, fed-batch, continuous, various configurations using membrane based cell recycle, and immobilized cell configurations have all been tested. Table 1.1 compares selected results from the literature. To date, the best results have been obtained using either a fed-batch or fed-batch with cell recycle configuration. In both of these configurations the fermentable sugar, usually glucose, is kept at 5-10 g/l by periodic addition of substrate and nutrients. This suggests that the strain displays substrate inhibition, however as discussed later, a poorly formulated medium may also play a role.

Most previous fermentation trials have used either glucose or starch hydrolyzate as the primary carbon and energy source. These materials are relatively easy to handle since they are completely soluble at the substrate concentration levels of interest and contain high concentrations of a single monomeric sugar (i.e. glucose) that is readily fermented. A few researchers have examined “dirtier” feedstocks such as biomass hydrolyzates (21-22). These materials have additional complicating factors such as the need to pretreat and enzymatically digest the feedstock, resulting in a mixed sugar product from the starting feedstock. Both Sequential Hydrolysis and Fermentation (SHF) and Simultaneous Saccharification and Fermentation (SSF) methods have been tired with favorable results; yields range from 70-100\% of theoretical depending upon the details of the experimental trial. SSF is a particularly attractive option since there appears to be a good match between the working ranges of temperature and $\mathrm{pH}$ between the enzymes and the fermentation organism, plus the metabolic versatility of acetogens results in high yield of acetate from the mixed sugar substrate.

The identity of the base used for $\mathrm{pH}$ control affects both fermentation performance and downstream recovery operations. When the desired final product is a salt, it makes sense to choose the base so that the salt is made directly in the fermentor. For example, when producing calcium magnesium acetate (CMA - a de-icing agent used for environmentally sensitive applications), it makes sense to neutralize the fermentation with dolomite $\left(\mathrm{CaCO}_{3} \cdot \mathrm{MgCO}_{3}\right)$ or dolime $\left(\mathrm{Ca}(\mathrm{OH})_{2} \cdot \mathrm{Mg}(\mathrm{OH})_{2}\right)$. When acetic acid or another acidified derivative (e.g. acetate esters) is the desired product, an industrially viable processing scheme has to regenerate the base after recovery of the relevant cation from the broth. The alternative, stoichiometric production of a salt coproduct, is not practical at the projected production scale.

Sodium hydroxide has been a popular choice of base by previous investigators since it provides for good fermentation performance. However, downstream recovery operations are faced with the task of having to recover sodium acetate and regenerate sodium hydroxide from the broth. Sodium salts are very soluble in water and there are a limited number of technical options available for recovery and regeneration. Bipolar electrodialysis could potentially be used, but the electricity cost required for regenerating sodium hydroxide would contribute $\sim$ \$0.20-\$0.25 per gallon of ethanol, leading to questionable economics for biocommodity production if $\mathrm{NaOH}$ is selected as the base. 
As shown in Figure 1.3, Wang and Wang (6) found that both potassium and ammonium cations are inhibitory to $M$. thermoacetica. Other research has shown good fermentation performance using calcium carbonate, dolomite or related derivatives for $\mathrm{pH}$ control. For example, Parekh and Cheryan (23) were able to achieve final broth concentrations of $102 \mathrm{~g} / \mathrm{l}$ (as HAc) with 93\% conversion of the glucose feedstock using dolime for $\mathrm{pH}$ control in a fed batch fermentation with cell recycle provided by cross-flow membrane filtration. As will be discussed later in Task 2, it is relatively easy to regenerate calcium carbonate in the downstream recovery operation. Unfortunately a calcium based system suffers from the need to handle solid slurries, which is difficult for laboratory experiments, but could be handled in an industrial scale operation. Our initial laboratory work focused on sodium hydroxide as the base, but we also showed that good fermentation performance and adequate $\mathrm{pH}$ control could be maintained using calcium carbonate as the neutralizing base.

This grant considers integration of an acetogenic fermentation with a corn wet milling operation. Glucose, in the form of starch hydrolyzate, is the primary carbon and energy source. The primary nutrient source is assumed to be either light steep water or corn steep liquor. Light steep water is the aqueous product of the steeping operation used to soften the kernels prior to grinding. It typically contains $\sim 6 \mathrm{wt} \%$ solids. Corn steep liquor is light steep water that has been evaporated to $\sim 50 \mathrm{wt} \%$ solids. The normal outlet for corn steep liquor in a wet milling operation is corn gluten feed (i.e. a mixture of the fiber fraction of the corn, corn germ meal when oil recovery is practiced on-site, plus corn steep liquor - an animal feed ingredient for cattle and other ruminants) although corn steep liquor is also sold in relatively small quantities as a nutrient source for industrial fermentations such as penicillin production.

Several previous researchers $(14,16-18)$ have shown that corn steep liquor can provide nutrients for an acetogenic fermentation. The experimental work in this grant builds upon the previous work of others to show potential integration issues for an acetogenic fermentation with a host corn wet milling operation. As will be discussed later, the strain and media formulation used in the experimental portion of this work still results in a broth that is too rich in nutrients to be considered viable for an industrial fermentation. The results of this study suggest that $R \& D$ activities in strain selection and media development are prerequisites for any future development work.

\section{Methods and Materials}

Moorella thermoacetica ATCC 39073 (previously Clostridium thermoaceticum ATCC 39073) was acquired from the American Type Culture Collection (Manassas, VA) and successfully revived and cultured in shake flasks using the medium and conditions recommended by the American Type Culture Collection.

The maintenance media was a modification of that used by Wang et. al. (5). The composition of the modified base medium, in $\mathrm{g} / \mathrm{L}$, was as follows: Bacto yeast extract, 10.0; glucose, 20; $\mathrm{KH}_{2} \mathrm{PO}_{4}, 1.0 ; \mathrm{MgCl}_{2}-6 \mathrm{H}_{2} \mathrm{O}, 0.33$; $\mathrm{CaCl}_{2}-2 \mathrm{H}_{2} \mathrm{O}, 0.05$; sodium thioglycolate (a reductant), 0.5; resazurin (a redox potential indicator), 0.05. A trace mineral mixture known as Wolfe's mineral solution (Table 1.2) was added at $1 \mathrm{~g} / \mathrm{l}$. The $\mathrm{pH}$ of the media was adjusted to 7.25 using $\mathrm{NaHCO}_{3}$. This required the addition of approximately $7 \mathrm{~g} / \mathrm{L} \mathrm{NaHCO}_{3}$. 
Following preparation, $40 \mathrm{ml}$ of the media was added into $50 \mathrm{ml}$ Wheaton bottles, sealed with a butyl rubber septum and aluminum crimp retainer, and autoclaved for 30 minutes at 20 psi $\left(121^{\circ} \mathrm{C}\right)$. After cooling, the bottles were flushed with instrument grade $\mathrm{CO}_{2}\left(\mathrm{O}_{2}<10 \mathrm{ppm}\right.$, Airgas Corp.) supplied from a cylinder and gas regulator, through Tygon by using a needle inserted through the septum and vented with a second needle in order to remove oxygen and fully reduce the medium. After flushing, the bottles were pressured to 15 psia by removing the vent needle. Under these conditions, the final $\mathrm{pH}$ of the media was approximately 6.85. The bottles were inoculated with $10 \% \mathrm{vol} / \mathrm{vol}$ of a 3 day culture. Maintenance cultures were grown unshaken at $58{ }^{\circ} \mathrm{C}$ by placing the bottles in an incubator. Cultures were passed every 3 days.

A series of batch fermentations was done using either yeast extract or corn steep liquor (Sigma) as a nutrient source. Corn steep liquor is a very complex mixture containing complex ammonia, organic nitrogen, minerals, vitamins, lactic acid and sugars. It is produced from light steep water by evaporation to about $50 \mathrm{wt} \%$ total solids, during which some solids precipitate from the solution. Some of the precipitated solids are not soluble upon dilution. In the cases where corn steep liquor-based media was used, the solids were removed by diluting the nutrient to the desired concentration and then centrifugation at $3000 \mathrm{x}$ g prior to the addition of salts or glucose. About $90 \%$ of the raw corn steep liquor is soluble. Correction was made for the solids removal in media formulation.

The $\mathrm{pH}$ of corn steep liquor is about 4.5, so the $\mathrm{pH}$ was brought to 6.25 with $10 \mathrm{~N} \mathrm{NaOH}$ prior to adjusting the $\mathrm{pH}$ to 7.25 with $\mathrm{NaHCO}_{3}$ for culture adaptation and maintenance. Cultures were adapted over several weeks to grow at increasing concentrations of both nutrients. In the cases where medium was prepared in Wheaton bottles, we were unable to control $\mathrm{pH}$ and it was necessary to add significantly more $\mathrm{NaHCO}_{3}$ to buffer the effects of the lactic acid present in the corn-based media.

Fermentation was carried out in a modified 3L Bellco spinner flask. The flask was modified to permit the addition and venting of $\mathrm{CO}_{2}$, and the addition of base for $\mathrm{pH}$ control. Sampling of fermentation broth was carried out via a septum cap and syringe. $\mathrm{CO}_{2}$ (instrument grade with $\mathrm{O}_{2}<10 \mathrm{ppm}$ ) was added to the fermentor continuously to maintain the medium in a reduced state and to exclude oxygen. $\mathrm{CO}_{2}$ was provided from a cylinder with a gas regulator, a needle valve for fine control and was measured with a rotameter. Prior to inoculation, the fermentor was sparged with $\mathrm{CO}_{2}$, at $1 \mathrm{~L} / \mathrm{min}$, for $2-4 \mathrm{hr}$, to fully reduce the media. During the run the $\mathrm{CO}_{2}$ flow rate was reduced to about $0.1 \mathrm{vol} / \mathrm{vol} / \mathrm{min}$.

The $\mathrm{pH}$ of the fermentation was maintained at 6.90 by the controlled addition of $10 \mathrm{~N}$ $\mathrm{NaOH}$. A pH probe (Hanna Instruments $\mathrm{pH}$ 500) was inserted into the fermentor. The probe was connected to a $\mathrm{pH}$ controller that controlled an on/off peristaltic pump (Cole-Parmer Masterflex L/S). The pump delivered $\mathrm{NaOH}$ solution from a sterile media bottle with sterile vent filter through Teflon tubing to the fermentor. $\mathrm{pH}$ was controlled to within +/- 0.05 units.

The entire flask was placed in an incubator held at $58{ }^{\circ} \mathrm{C}$ to maintain temperature control during the runs. Figure 1.4 contains photos of the incubator and fermentor flask. The gas 
cylinder to the left of the incubator provided carbon dioxide. The $\mathrm{pH}$ control system is on top of the incubator. The small bottles to the left of the fermentor are the maintenance cultures.

The base media was prepared as described above, however, the yeast extract (or corn steep liquor), glucose, and salts were each autoclaved separately and then combined in the fermentor. In addition, trace mineral salts $(1 \mathrm{ml} / \mathrm{L})$ were added by syringe through the sample septum. Each fermentation was inoculated with $200 \mathrm{ml}(10 \% \mathrm{v} / \mathrm{v})$ of a 32-40 hr culture grown in $50 \mathrm{ml}$ Wheaton bottles, as described above.

Acetate and glucose in the culture supernatant were analyzed by Waters HPLC. The Waters 2690 separation module was fitted with both a Waters 2410 refractive index detector for sugars, and a Waters 996 photodiode array detector for organic acids. The column was a BioRad Aminex HPX-87H column. Samples were injected and eluted in an isocratic mode using 10mM $\mathrm{H}_{2} \mathrm{SO}_{4}$ as the mobile phase, at a flow rate of $0.6 \mathrm{ml} / \mathrm{min}$, at $35^{\circ} \mathrm{C}$. Both acetate concentration and glucose concentration were determined from standard curves prepared by running samples of known concentration.

Optical density measurements of the fermentation broths were made by spectrophotometry (Beckman DU 640) at $600 \mathrm{~nm}$.

\section{Results}

We found it was necessary to adapt the strain to the medium prior to attempting a batch fermentation run. Even for yeast extract, several passes were required. Strain adaptation was even slower for the corn steep liquor based media; sometimes several weeks were required. Table 1.3 lists all of the fermentation runs attempted with either yeast extract or corn steep liquor media. Comments are included in the table to indicate some of the key observations including the troublesome and aborted runs.

\section{Fermentation Runs with Yeast Extract Media Neutralized with $\mathrm{NaOH}$}

Figure 1.5 displays the batch fermentation results using yeast extract (10 g/l) media. The lag period for this run was slightly less than one day, after which the glucose concentration fell and the acetate concentration rose. The sum of the glucose and acetate concentrations is relatively constant over the course of the fermentation, indicating a good material balance.

\section{Fermentation Runs with Corn Steep Liquor Media Neutralized with $\mathrm{NaOH}$}

The objective for these runs was to demonstrate that a corn-based medium could be used to obtain a final acetate concentration and fermentation rate that was comparable to the yeast extract medium. Figure 1.6 displays the batch fermentation results for a run with corn steep liquor (100 g/l wet) media. As expected, the glucose concentration fell over time while the acetate concentration rose. Unfortunately, all our batch fermentations with corn steep liquor media produced precipitates, so cell density could not be readily monitored by spectrometry. 
Another difference we observed with the corn steep liquor media was that the sum of the concentration of glucose+acetate was not constant over time. Rather than being an issue with the fermentation procedure or analytical method, we believe the cause of the apparent non-closure in the material balance was the fact that the organism was synthesizing acetate from other components in the corn steep liquor (e.g. sugars other than glucose, lactate, etc.)

Figures 1.7 and 1.8 compares chromatograms for sugars and organic acid analyses of batch fermentation runs using both the yeast extract and corn steep liquor media. The figures are arranged to allow qualitative comparisons between start of run and end of run for each media, plus comparison between the two media. Several observations can be made:

1) The lactic acid peak (Figure 1.8, retention time $=12.9 \mathrm{~min}$ ) is much smaller at the end of the CSL media run than at the beginning, suggesting that lactate was being consumed. We established a calibration curve for lactate and tracked its concentration over the course of the fermentation. Lactate levels generally decreased over the course of the fermentations, however there were periods were the lactate levels actually increased. There are several possible explanations. One likely reason is that corn steep liquor contains both lactic acid/lactate and higher internal esters of lactic acid (i.e. lactolylactic acid and higher oligomers) which are formed during the evaporation of light steep water:
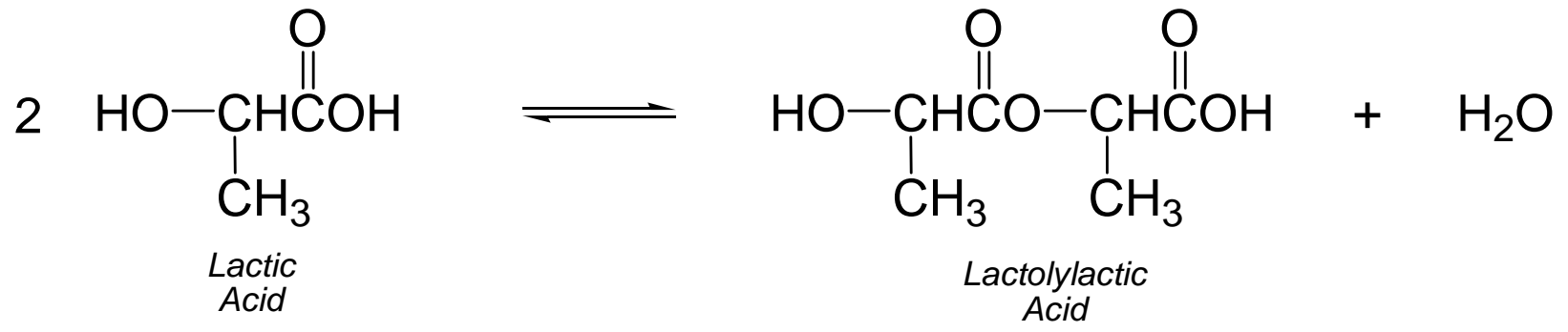

In a dilute aqueous solution at near neutral $\mathrm{pH}$, the lactolylactic acid and higher oligomers will slowly hydrolyze back to monomeric lactate. A temporary increase in the amount of lactate present in the broth would be observed if the oligomer hydrolysis reaction is faster than the rate at which the organism consumes lactate. If true, this complicates the material balance since lactate and all associated oligomers have to be measured and accounted. Yeast extract does not contain a significant amount of lactic acid, so material balances for runs with yeast extract media are much less complicated.

2) The sugar chromatograms (Figure 1.7) at the end of run for both the yeast extract and corn steep liquor media showed a significant peak at a retention time of 16 minutes that was not present at the start of either fermentation. Previous investigators $(14,16)$ have suggested that that batch fermentations of glucose using non-adapted library strains begin to accumulate fructose once the cells stop growing. Fructose does not elute at 16 minutes with our HPLC method, so the identity of this compound is still unknown. Nonetheless, this undesirable trait can probably be eliminated by strain development or handled by a fermentation design that maintains the cells in log phase growth. 
Figure 1.9 compares acetate production curves for batch fermentations at various corn steep liquor concentrations. The starting medium in all cases was formulated at a constant initial glucose concentration of $50 \mathrm{~g} / \mathrm{l}$, without correction for the additional glucose contained in the corn steep liquor. The data shown in Figure 1.9 have had the lag time removed to facilitate comparisons. The initial log phase volumetric productivity ranged from $0.025-0.75 \mathrm{~g} / \mathrm{l} / \mathrm{hr}$; final acetate concentration ranged from 2.5 - $38 \mathrm{~g} / \mathrm{l}$ (as HAc). Both volumetric productivity and final acetate concentrations increased with increasing corn steep liquor concentration in the media.

Figure 1.10 compares acetate production for the yeast extract and corn steep liquor media. The performance of the $40 \mathrm{~g} / \mathrm{l}$ (wet) corn steep liquor ( $20 \mathrm{~g} / \mathrm{l}$ dry basis) medium was about the same as the performance of the $10 \mathrm{~g} / \mathrm{l}$ yeast extract medium. This suggests that, on a per mass basis, yeast extract is twice as effective as a nutrient source when compared to corn steep liquor.

\section{Use of $\mathrm{CaCO}_{3}$ for Neutralization}

One of the goals of the study was to show that $\mathrm{CaCO}_{3}$ could be used as the neutralizing base for the fermentation. We conducted a series of bottle cultures using the yeast extract media augmented with various levels of $\mathrm{CaCO}_{3}$. As shown in Figure 1.11, higher levels of $\mathrm{CaCO}_{3}$ resulted in higher concentrations of acetate in the bottle culture. Several reasons for improved performance with $\mathrm{CaCO}_{3}$ could be postulated. For example, the $\mathrm{pH}$ of the bottle cultures is not controlled; higher levels of $\mathrm{CaCO}_{3}$ could just be increasing the buffering capacity of the media. Nonetheless, the data of Figure 1.11 suggests there is no need for adaptation of the strain when switching from sodium to calcium as the neutralizing base cation.

Unfortunately, our batch fermentation equipment was not designed for sterile addition of solid or slurried $\mathrm{CaCO}_{3}$. For purposes of demonstrating $\mathrm{pH}$ control with a calcium based system, we decided to conduct a simplified experiment to show that the $\mathrm{pH}$ of an aqueous solution containing acetic acid and calcium carbonate could be controlled by manipulating the partial pressure of $\mathrm{CO}_{2}$ in the headspace.

Prior to any experimental work, we set-up an aqueous electrolyte model that related $\mathrm{pH}$ of the solution to variations in the total acetate concentration and $\mathrm{CO}_{2}$ partial pressure at $25{ }^{\circ} \mathrm{C}$ (see Figure 1.12). The resulting set of non-linear algebraic equations was then solved, producing the curves shown in Figure 1.13. Although this simplified model does not take into account the buffering effects of other media components or temperature, the curves in Figure 1.13 show that $\mathrm{pH}$ can be controlled by manipulating the $\mathrm{CO}_{2}$ partial pressure in the headspace.

We experimentally tested $\mathrm{pH}$ control of an aqueous calcium acetate/calcium carbonate slurry by varying the composition of the headspace gas. Approximately 30 grams of calcium carbonate were added to $710 \mathrm{ml}$ of a $0.0117 \mathrm{~g} / \mathrm{l}$ (as acetate) calcium acetate solution. The flask was initially gassed with pure $\mathrm{CO}_{2}$ at about $0.5 \mathrm{lpm}$. The $\mathrm{pH}$ reached an equilibrium value of 6.01, which agrees with the prediction in Figure 1.13 after accounting for the fact that atmospheric pressure at our lab in Colorado is about $0.83 \mathrm{~atm}$. The flask was then gassed with pure nitrogen. The $\mathrm{pH}$ increased quickly at first followed by a slower asymptotic rise. After two hours, the $\mathrm{pH}$ of the solution was 8.07, again in agreement with the prediction of Figure 1.13. 
We found that by varying the ratio of $\mathrm{CO}_{2}$ to $\mathrm{N}_{2}$ in the gas mixture, the $\mathrm{pH}$ could be set at any desired level between these two limits and could be controlled to within +/- 0.05 units.

The gas ratio was then set to give a $\mathrm{pH}$ of 6.95. To simulate a fermentation, we continuously added to the flask a dilute aqueous solution of acetic acid at a rate equivalent to 1 $\mathrm{g} / \mathrm{l} / \mathrm{hr}$, roughly corresponding to the volumetric productivity of an acetogenic fermentation. The gas ratio was manually adjusted with needle valves and the $\mathrm{pH}$ of the solution was successfully controlled between 6.84 and 6.95 over a period of 1 hour, thus demonstrating $\mathrm{pH}$ control in the simplified experimental apparatus.

\section{Discussion}

The fermentation results presented here are in qualitative agreement with the prior literature. We found the strain was quite adaptable to new fermentation conditions and capable of metabolizing a variety of substrates. As in the literature, using the depository type strains and standard media formulations without extensive adaptation/selection procedures results in batch fermentations that give reasonable final acetate concentrations but often fail to extinguish fermentable sugars in the media. Two critical issues need to be addressed in future work: strain adaptation/selection and media formulation. Parallel development has to be done because of interaction between the strain and its media. Furthermore, additional constraints arise because of integration issues with downstream recovery operations and overall process economics.

Prior work in the literature has recognized the importance of strain adaptation and selection. The paper by Parekh and Cheryan (15) is especially good at pointing out the need for strain adaptation/selection. They showed incomplete batch fermentations result when using four different depository strains in a medium with $20 \mathrm{~g} / \mathrm{l}$ of glucose and a yeast extract+tryptone nutrient source. But, by applying adaptation and selection procedures, they were able to produce a strain that completely converted a $35 \mathrm{~g} / \mathrm{l}$ glucose medium, producing a final broth concentration of $29 \mathrm{~g} / \mathrm{l}$ of acetate. Classical mutagenesis methods have also been used by several researchers to produce improved strains $(10,19)$.

We feel that inadequate attention has been paid in the literature to the impact of media formulation on downstream recovery operations and overall process economics. No truly industrial media formulations have been developed for an acetogenic fermentation. Most prior studies use a complex undefined media containing yeast extract or a combination of yeast extract and a proteolyzed protein source such as tryptone (proteolyzed casein protein from milk). A typical formulation contains $10-50 \mathrm{~g} / \mathrm{l}$ of glucose plus $10 \mathrm{~g} / \mathrm{l}$ of the undefined nutrient source. The cost of just the undefined media component alone would contribute $\$ 9.20$ per gallon of ethanol (denatured) at a typical bulk price of $\$ 10$ per kg for yeast extract.

Just as importantly, the high nutrient loading leads to problems in downstream recovery operations - an issue that has been nearly universally ignored in the prior literature work on acetogenic fermentations. Frankly, based on our laboratory experience the fermented broth is so dark from the high nutrient loadings that it is difficult to conceive of a recovery system capable of producing a high purity product. We initially approached media formulation from the point of view that the economics could be improved just by switching the complex nitrogen source from 
yeast extract or yeast extract+tyrptone to corn steep liquor. As will be shown in Task 3, this switch does bring the economics in-line with the needs of an industrial fermentation. However, switching the media from high concentrations of one complex nitrogen source to high concentrations of a different complex nitrogen source does nothing to improve integration of the fermentation and recovery steps.

We recommend future work should start with a defined media containing a simple nitrogen source (e.g. ammonia). Combining strain adaptation/selection with a defined media should result in both an improvement in process economics and improved integration with downstream recovery operations. Eliminating undefined media components will also simplify laboratory analytical methods and make it easier to separate the effects of media limitations from substrate/product inhibition.

There is some precedent for believing a defined media is technically feasible. Lundie and Drake (27) developed a minimally defined growth media for $M$. thermoacetica that contains

glucose as the carbon and energy source, ammonium sulfate as the nitrogen source, nicotinic acid as the sole essential vitamin, plus other components such as a reductant, trace minerals, inorganic buffers and $\mathrm{CO}_{2}$ in the headspace. While the minimal media was capable of supporting growth, the performance was much better when the organism was grown on an undefined media containing yeast extract as illustrated in Figure 1.14. A later report (28) states that when the minimal medium is supplemented with biotin (a vitamin) the fermentation performance is essentially identical to the performance of undefined media. A similar study was carried out to find a minimally defined medium for another acetogen, $C$. thermoautotrophicum (28). The results of this study, displayed in Figure 1.15, also show that growth could occur using only ammonium sulfate as the nitrogen source and nicotinic acid as the sole essential vitamin, but in this case the vitamin biotin was stimulatory. The economics of our proposed recommendation are explored later in Task 3.

\section{Sub-Task Review}

The description of the sub-tasks, taken from Appendix B Statement of Work in the original proposal, is repeated below:

Task 1.1 Analytical Method Validation - Published HPLC analytical protocols for measuring sugars, especially dextrose, in aqueous solutions will be implemented and validated on our equipment. Likewise, published HPLC analytical protocols for measuring organic acids, especially lactate and acetate, will be implemented and validated. The outcome of this task will be the ability to accurately measure sugars and organic acid content of starch hydrolyzate, corn steep liquor and fermentation broth.

Task 1.2 Construction - Two fully instrumented, temperature and pH controlled, 1 liter batch fermentors will be assembled. Cell mass will be measured off-line by optical density. Fermentation protocols will be established and the ability to generate reproducible runs with good mass balance closure will be demonstrated prior to entering Task 1.4. The media formula given in (17), based on starch hydrolyzate and corn steep liquor provided by our contacts within the wet milling industry, will be used for the shakedown runs. Clostridium thermoaceticum 
ATCC 39073, C. thermoaceticum ATCC 49707, or similar, will be used as the test strain. The outcome of this task will be the assembly and shakedown of the equipment needed to support the testing in Task 1.4.

Task 1.3 Testing - A series of batch fermentation runs designed to obtain the data necessary for creating a kinetic model of the fermentation will be conducted. The effects of temperature, $\mathrm{pH}$, substrate inhibition for both starch hydrolyzate and corn steep liquor, and the effects of product inhibition will be examined. Runs that do not exhibit good mass balance closure will be discarded and the conditions repeated with another run. The outcome of this task will be a set of high quality experimental data that can be used for model development.

Task 1.4 Data Analysis - The data from Task 1.4 will be processed into a kinetic model for cell growth and acetate production. The outcome of this task will be used for further modeling efforts in Task 3.1.

The following discussion compares the work actually accomplished against the original proposal subtasks:

Task 1.1 Analytical Method Validation - Complete.

Task 1.2 Construction - Complete.

Task 1.3 Testing - Complete.

Task 1.4 Data Analysis - Complete.

\section{References}

1) Drake, H.L., (editor), Acetogenesis, Chapman \& Hall, 1994.

2) Collins, M.D., Lawson, P.A., Williams, A., Cordoba, J.J., Fernandez-Garayzabal, J., Garcia, P., Cai, J., Hippe, H. Farrow, J.A., “The Phylogeny of the Genus Clostridium: Proposal of Five New Genera and Eleven New Species Combinations”, International Journal of Systematic Bacteriology, Vol. 44, No. 4, p. 812 - 826, 1994.

3) Wiegel, J., Carreira, L.H., Garrison, R.J., Rabek, N.E., Ljungdahl, L.G., “Calcium Magnesium Acetate (CMA) Manufacture from Glucose by Fermentation with Thermophilic Homoacetogenic Bacteria”, Chapter 16 in: Wise, D.L., Levendis, Y.A., Metghalchi, M. (editors), Calcium Magnesium Acetate: An Emerging Bulk Chemical for Environmental Applications, Elsevier, New York, 1991.

4) Karnholz, A., Kusel, K., Grossner, A., Schramm, A., Drake, H.L., “Tolerance and Metabolic Response of Acetogenic Bacteria Toward Oxygen”, Applied and Environmental Microbiology, Vol. 68, No. 2, p. 1005 - 1009, 2002. 
5) Wang, D.I., Fleishchaker, R.J., Wang, G.Y., “A Novel Route to the Production of Acetic Acid by Fermentation”, AIChE Symp. Ser. No. 181, 74, p. 105-110, 1978.

6) Wang, G., Wang, D.I. “Elucidation of Growth Inhibition and Acetic Acid Production by Clostridium thermoaceticum”, Applied and Environmental Microbiology, Vol. 47, No. 2, p. 294298, 1984.

7) Sugaya, K., Tuse, D., Jones, J.L., "Production of Acetic Acid by Clostridium thermoaceticum in Batch and Continuous Fermentations”, Biotechnology and Bioengineering, Vol. 28, p. 678683, 1986.

8) Yang, S.T., Tang, I.C., Okos, M.R., "Kinetics and Mathematical Modeling of Homoacetic Fermentation of Lactate by Clostridium formicoaceticum”, Biotechnology and Bioengineering, Vol. 32, p. 797-802, 1988.

9) Tang, I.C, Yang, S.T., Okos, “Acetic Acid Production from Whey Lactose by the Co-Culture of Streptococcus lactis and Clostridium formicoaceticum”, Applied Microbiology and Biotechnology, Vol. 28, p. 138-143, 1988.

10) Schwartz, R.D., Keller Jr., F.A., "Isolation of a Strain of Clostridium thermoaceticum Capable of Growth and Acetic Acid Production at pH 4.5”, Applied and Environmental Microbiology, Vol. 43, No. 1, p. 117-123, 1982.

11) Schwartz, R.D., Keller Jr., F.A., “Acetic Acid Production by Clostridium thermoaceticum in pH Controlled Batch Fermentations at Acid pH”, Applied and Environmental Microbiology, Vol. 43, No. 6, p. 1385-1392, 1982.

12) Schwartz, R.D., Keller Jr., F.A., “Acetic Acid by Fermentation”, US Patent 4,371,619, Feb. 1, 1983. Assignee: Union Carbide Corporation.

13) Keller Jr., F.A., Ganoung, J.S, Luenser, S.J., "Mutant Strain of Clostrium thermoaceticum Useful for the Preparation of Acetic Acid”, US Patent 4,513,084, Apr. 1, 1985. Assignee: CPC International, Inc.

14) Shah, M.M., Cheryan, M., “Acetate Production by Clostridium thermoaceticum in Corn Steep Liquor Media”, Journal of Industrial Microbiology, Vol. 15, p. 424-428, 1995.

15) Parekh, S.R., Cheryan, M., “Acetate Production from Glucose by Clostridium thermoaceticum”, Process Biochemistry International, p. 117-121, August, 1990.

16) Witjitra, K., Shah, M.M, Cheryan, M., "Effect of Nutrient Sources on Growth and Acetate Production by Clostridium thermoaceticum”, Enzyme and Microbial Technology, 19, p. 322327, 1996. 
17) Bock, S.A. Fox, S.L. Gibbons, W.R., "Development of a Low-Cost, Industrially Suitable Medium for the Production of Acetic Acid from Clostridium thermoaceticum", Biotechnology and Applied Biochemistry, Vol. 25, p. 117-125, 1997.

18) Balasubramanian, N., Kim, J.S., Lee, Y.Y., "Fermentation of Xylose into Acetic Acid by Clostridium thermoaceticum", Applied Biochemistry and Biotechnology, Vol. 91-93, p. 367376, 2001.

19) Parekh, S.R., Cheryan, M., "Production of Acetate by Mutant Strains of Clostridium thermoaceticum”, Applied Microbiology and Biotechnology, Vol. 36, p. 384-387, 1991.

20) Parekh, S., Cheryan, M., "Fed-Batch Fermentation of Glucose to Acetate by an Improved Strain of Clostridium thermoaceticum", Biotechnology Letters, Vol. 12, No. 11, p. 861-864, 1990.

21) Brownell, J.E., Nakas, J.P., "Bioconversion of Acid-Hydrolyzed Poplar Hemicellulose to Acetic Acid by Clostridium thermoaceticum”, Journal of Industrial Microbiology, Vol. 7, p. 1-6, 1991.

22) Borden, J.R., Lee, Y.Y., Yoon, H.H., "Simultaneous Saccharification and Fermentation of Cellulosic Biomass to Acetic Acid”, Applied Biochemistry and Biotechnology, Vol. 84-86, p. 963-970, 2000.

23) Parekh, S.R., Cheryan, M., "High Concentrations of Acetate with a Mutant Strain of $C$. thermoaceticum”, Biotechnology Letters, Vol. 16, No. 2, p. 139-142, 1994.

24) Shah, M.M., Cheryan, M., "Improvement of Productivity in Acetic Acid Fermentation with Clostridium thermoaceticum”, Applied Biochemistry and Biotechnology, Vol. 51/52, p. 413-422, 1995.

25) Parekh, S.R., Cheryan, M., "Continuous Production of Acetate by Clostridium thermoaceticum in a Cell-Recycle Membrane Bioreactor", Enzyme and Microbiology Technology, Vol. 16, p. 104-109, 1994.

26) Wang, G., Wang, D.I.C., "Production of Acetic Acid by Immobilized Whole Cells of Clostridium thermoaceticum”, Applied Biochemistry and Biotechnology, Vol. 8, p. 491-503, 1983.

27) Lundie Jr., L.L., Drake, H.L., “Development of a Minimally Defined Medium for the Acetogen Clostrium thermoacticum", Journal of Bacteriology, Vol. 159, No. 2, p. 700 - 703, 1984.

28) Savage, M.D, Drake, H.L., "Adaptation of the Acetogen Clostridium thermoautotrophicum to Minimal Medium”, Journal of Bacteriology, Vol. 165, No. 1, p. 315-318, 1986. 


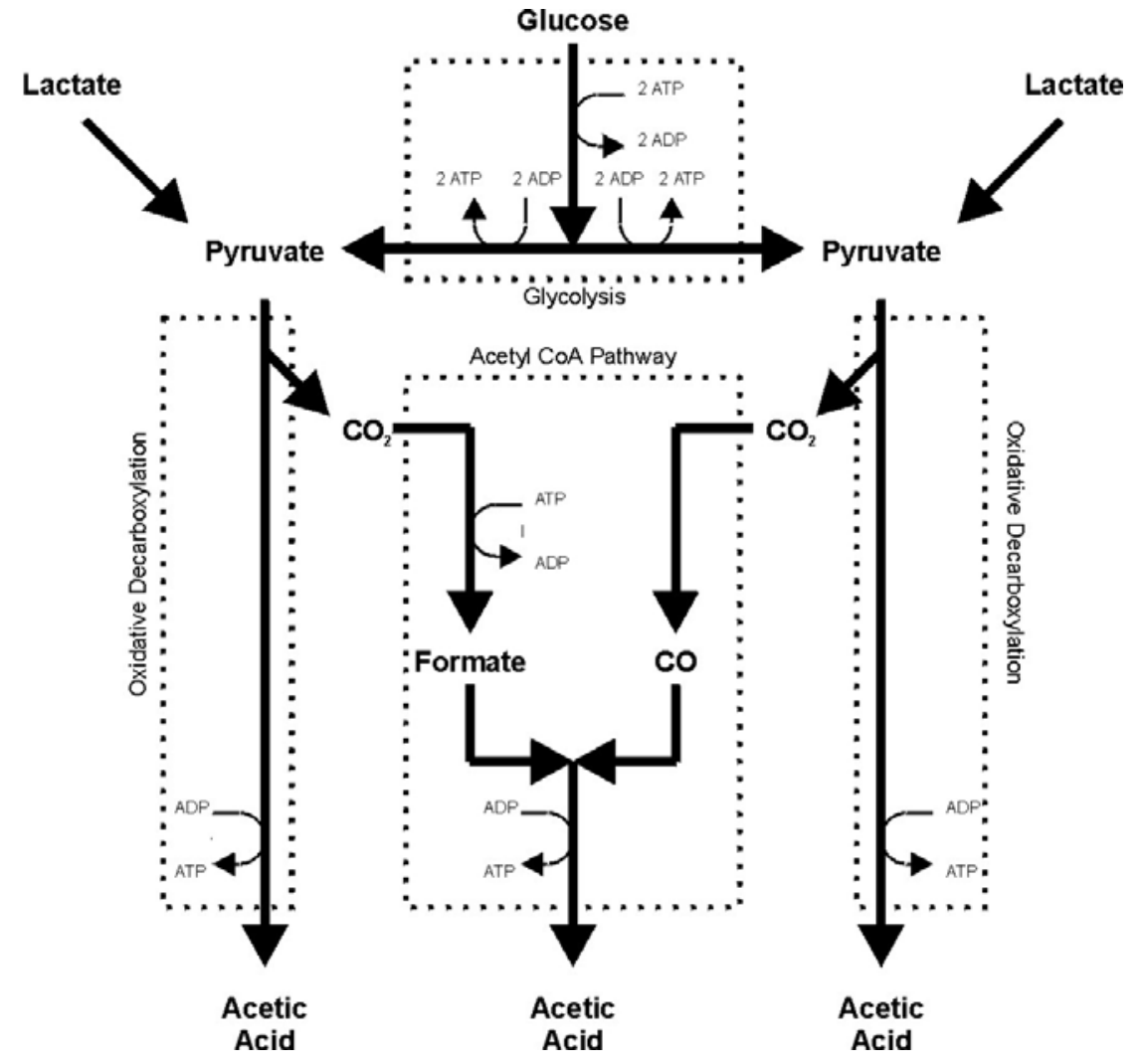

a) $C_{6}$ Sugars and Lactate

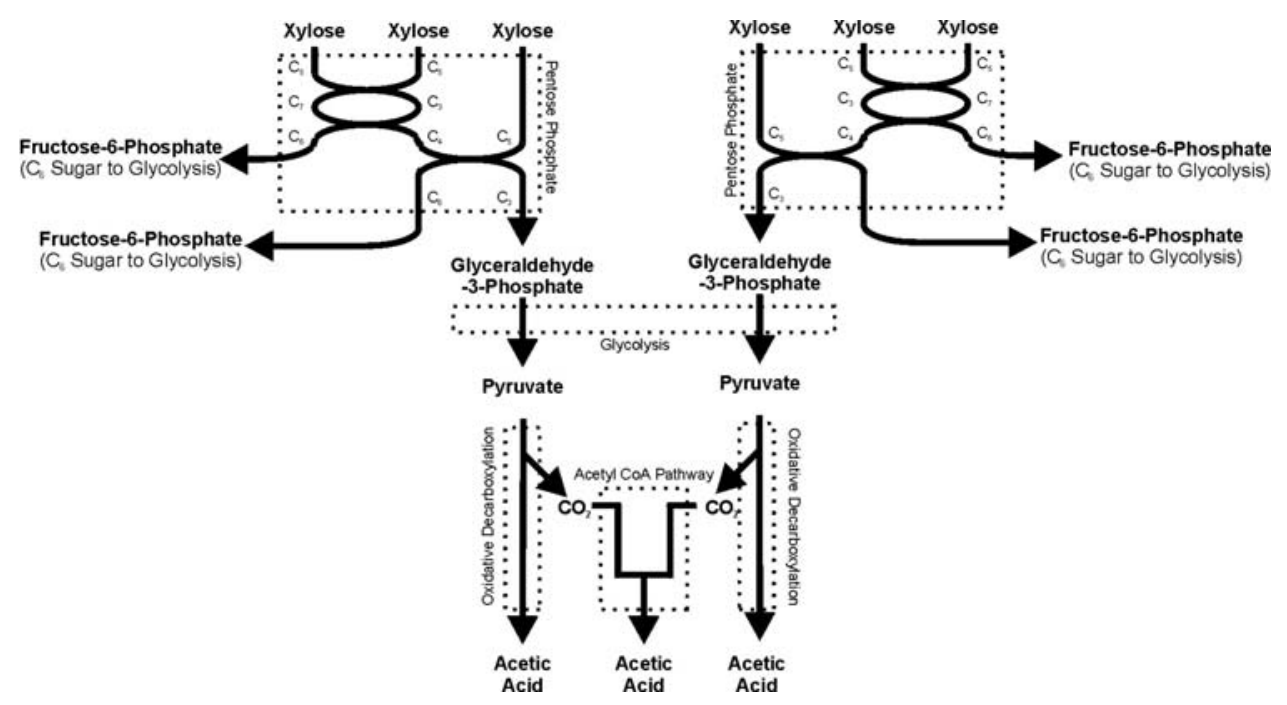

b) $\mathrm{C}_{5}$ Sugars

Figure 1.1 - Simplified Catabolic Pathways Used by Acetogens 

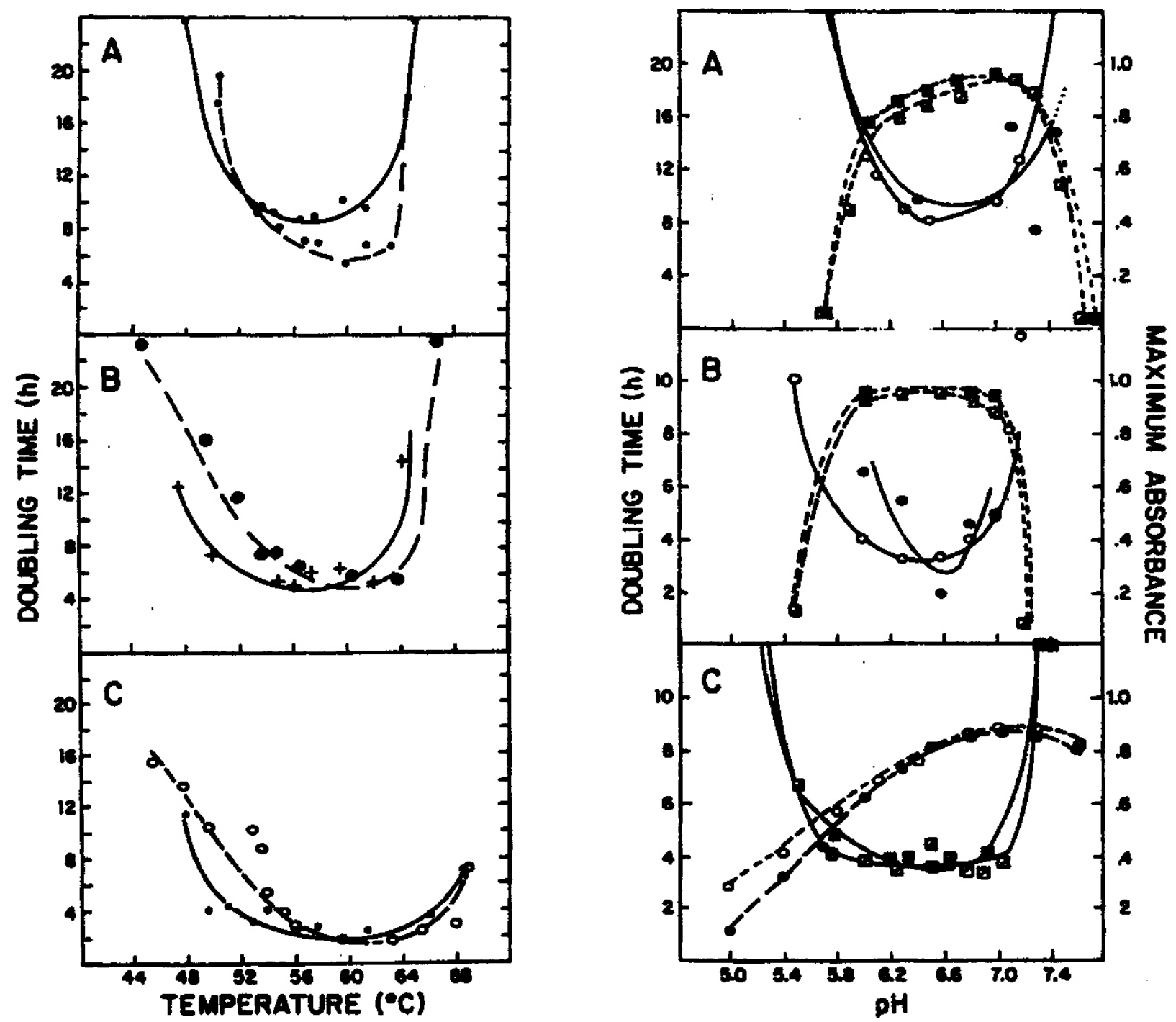

Figure 1.2 - Effect of Temperature and pH on Growth of A) $M$. thermoacetica, B) $M$. thermoautotrophicum and C) Thermoanaerobacter kivui (formerly Acetogenium kivui)

Taken from (3) 


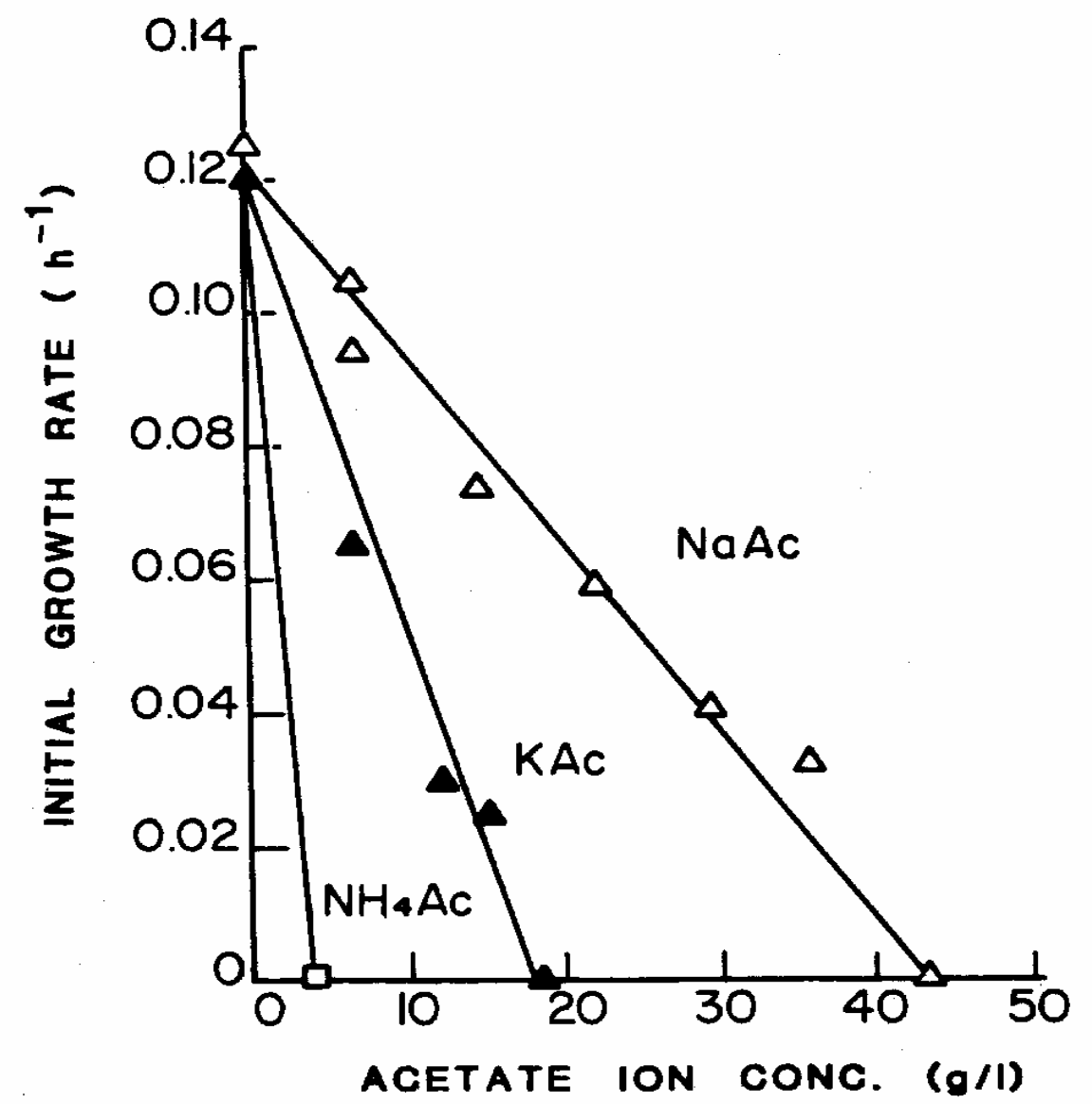

FIG. 6. Comparison of the initial growth rates of $C$. thermoaceticum at different acetate ion concentrations (in grams per liter). Symbols: $\square$, ammonium acetate; $\Delta$, potassium acetate; $\Delta$, sodium acetate.

Figure 1.3 - Inhibitory Effect of Ammonium and Potassium Cations Taken from (6) 


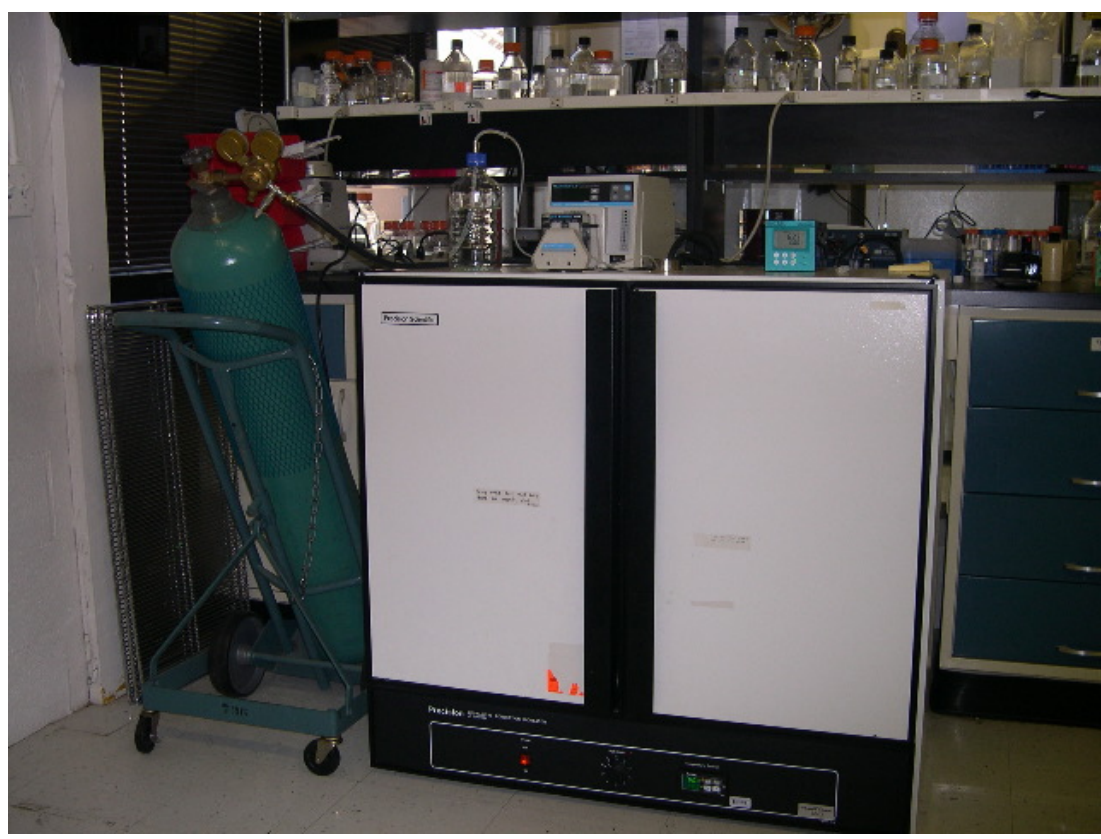

a) External View of Incubator, $\mathrm{CO}_{2}$ Supply and pH Control System

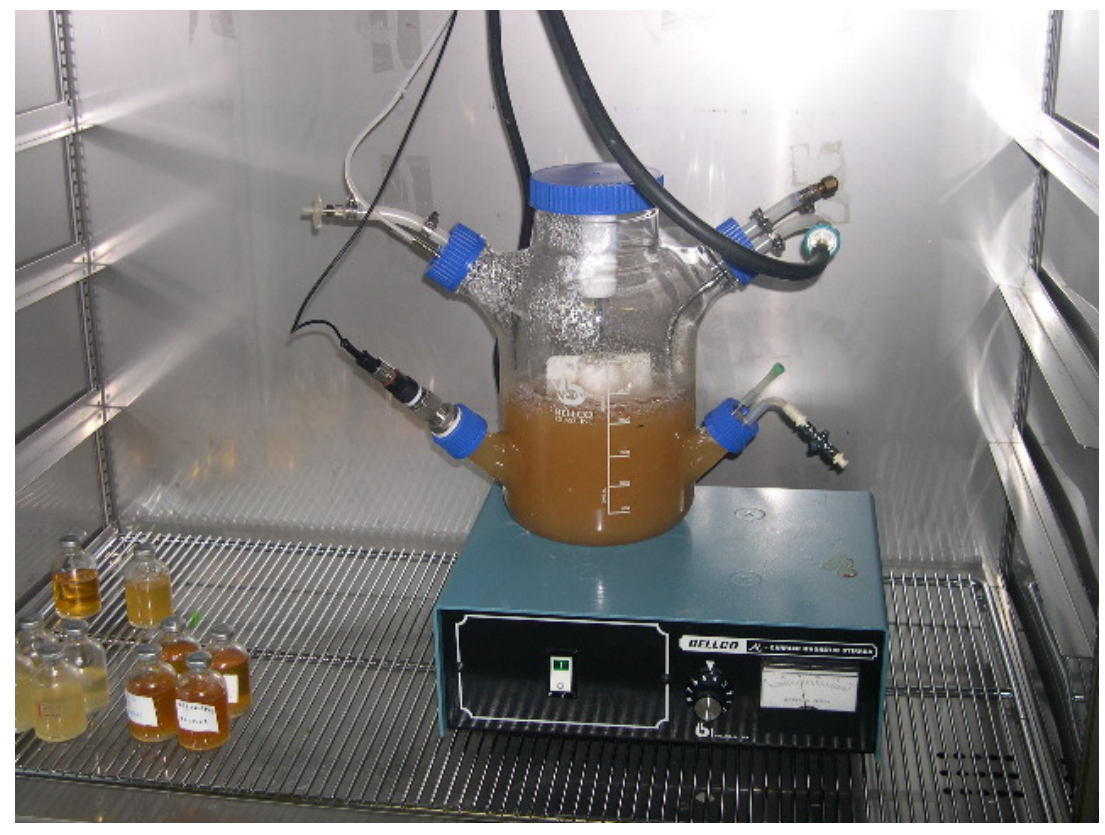

b) Modified 3 L Spin Flask, Stirrer, and Maintenance Cultures

Figure 1.4 - Fermentation Apparatus 
Figure 1.5 - Batch Fermenation using Yeast Extract (10 g/l) Media

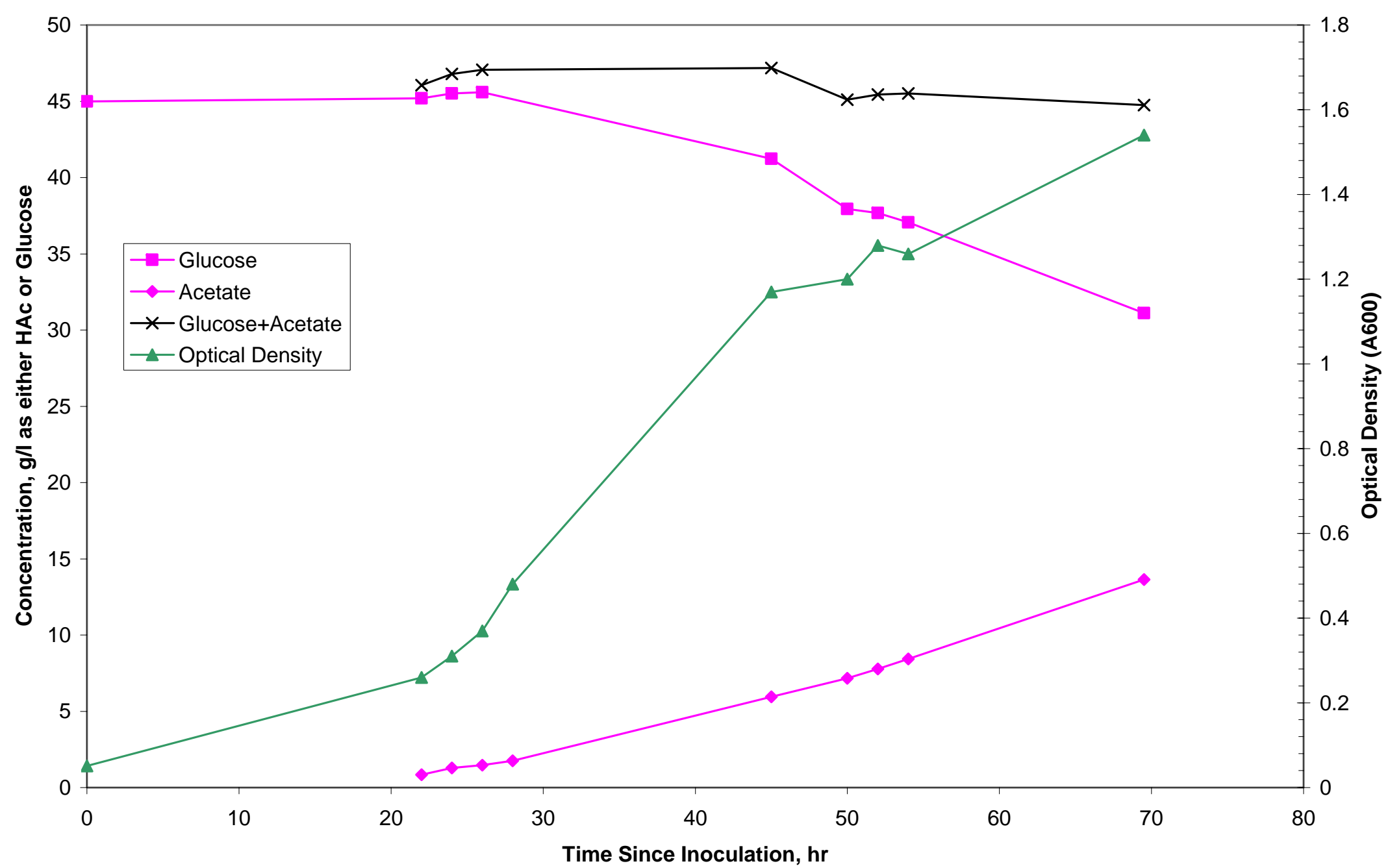


Figure 1.6 - Batch Fermentation Using Corn Steep Liquor (100 g/l) Media

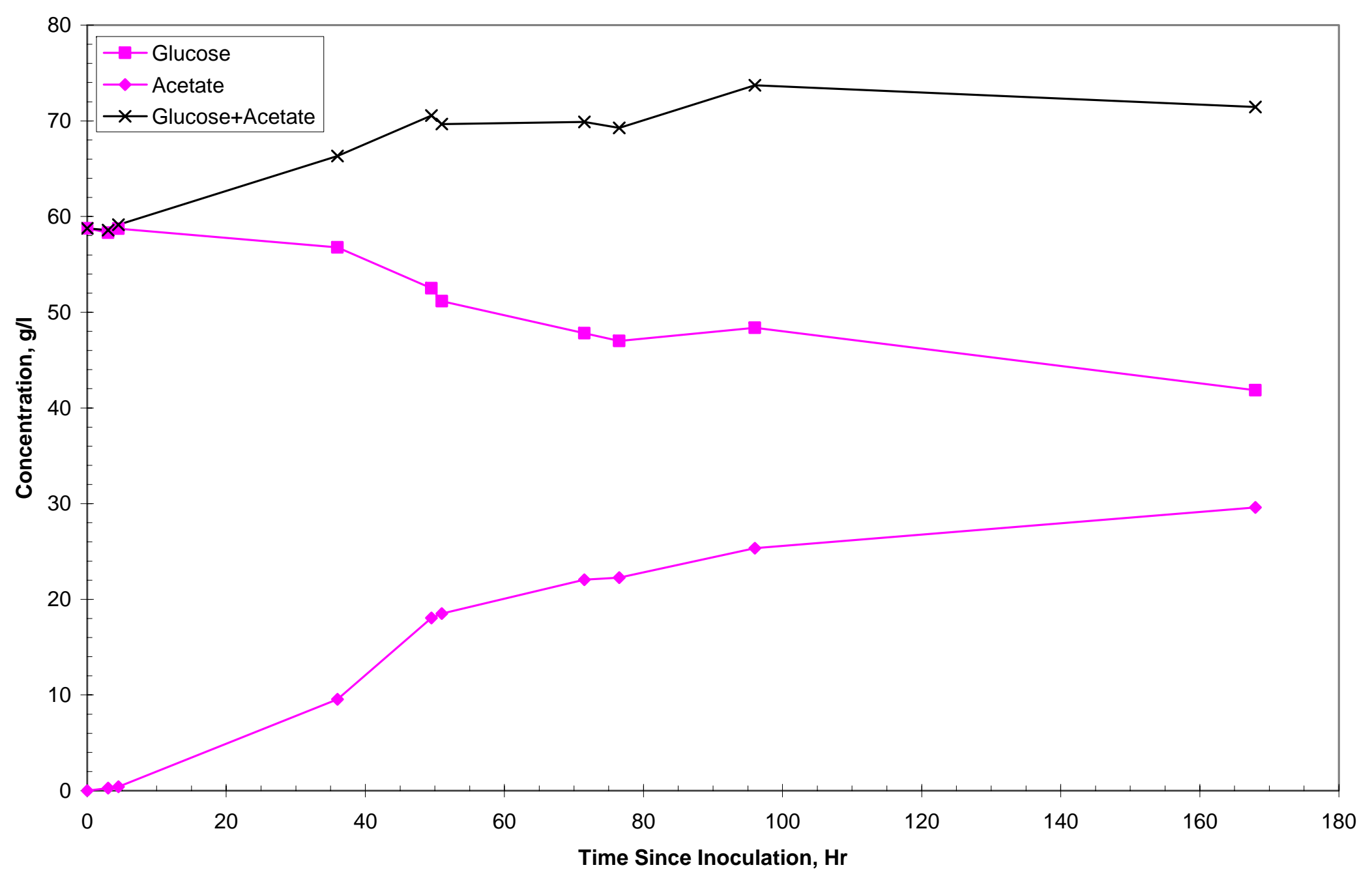


Figure 1.7 - Example Chromatograms for Sugars Analyses

a) YE Media at $\mathrm{T}=0 \mathrm{hr}$

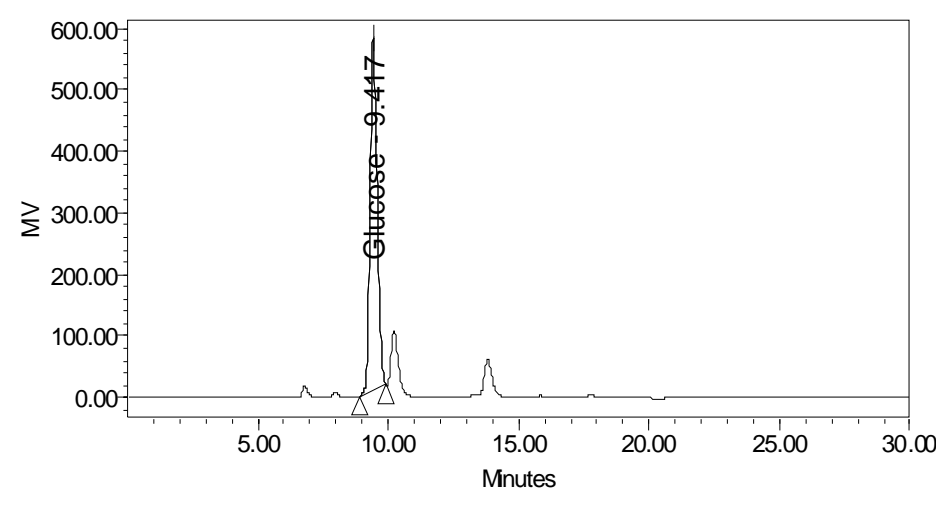

b) YE Media at $\mathrm{T}=69.5 \mathrm{hr}$

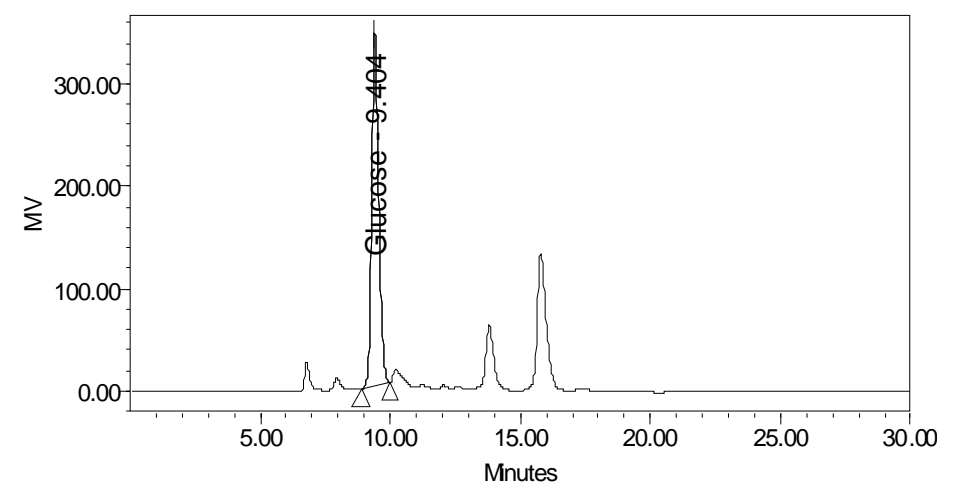

c) CSL Media (100 g/l) at $\mathrm{T}=0 \mathrm{hr}$

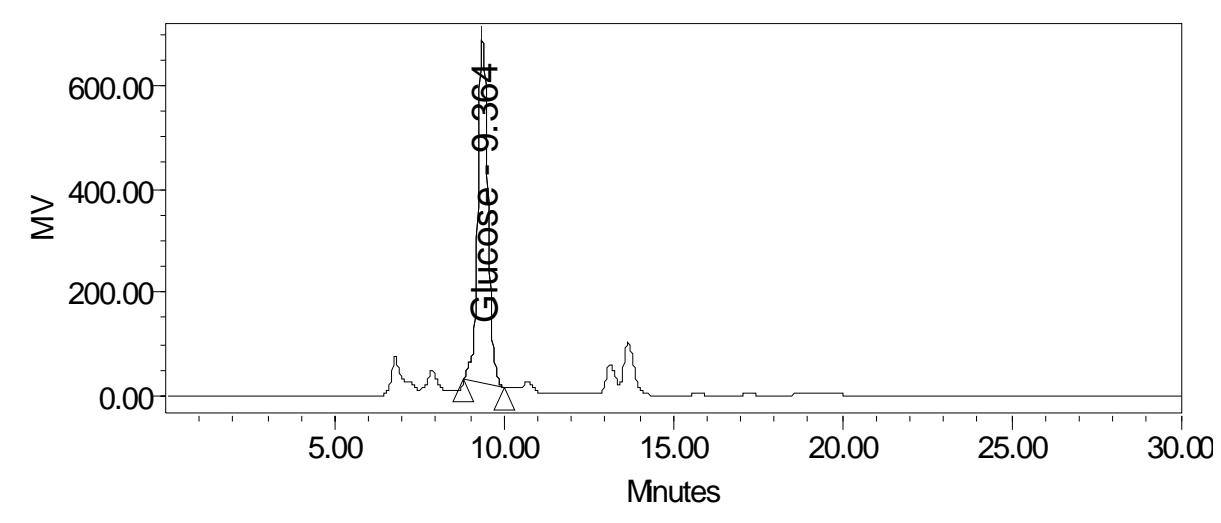

d) CSL Media (100 g/l) at T $=168 \mathrm{hr}$

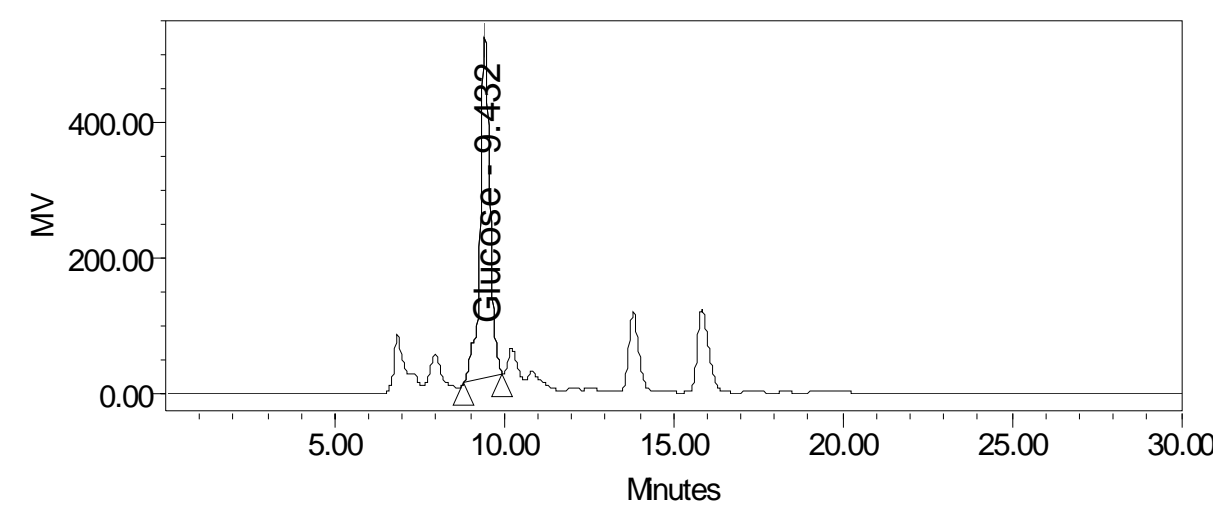




\section{Figure 1.8 - Example Chromatograms for Organic Acid Analyses}

a) YE Media at $\mathrm{T}=0 \mathrm{hr}$

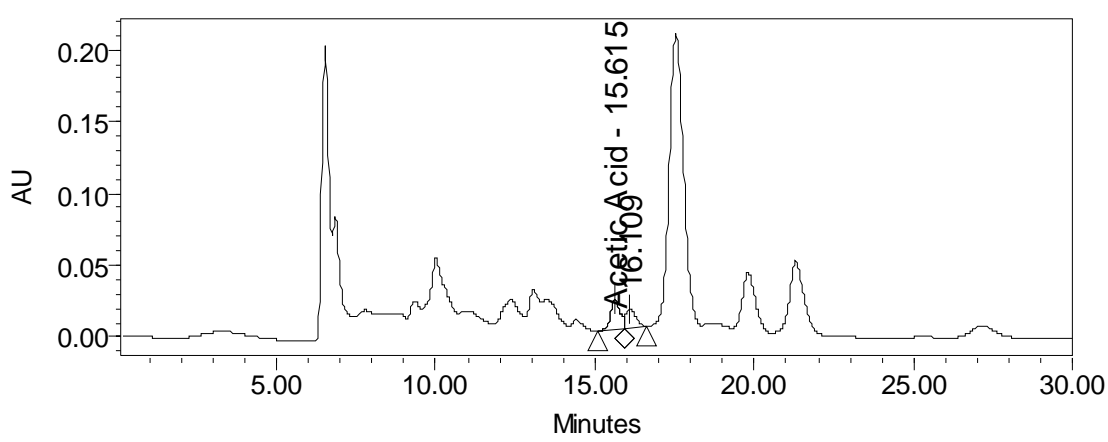

c) CSL Media (100 g/l) at $\mathrm{T}=0 \mathrm{hr}$

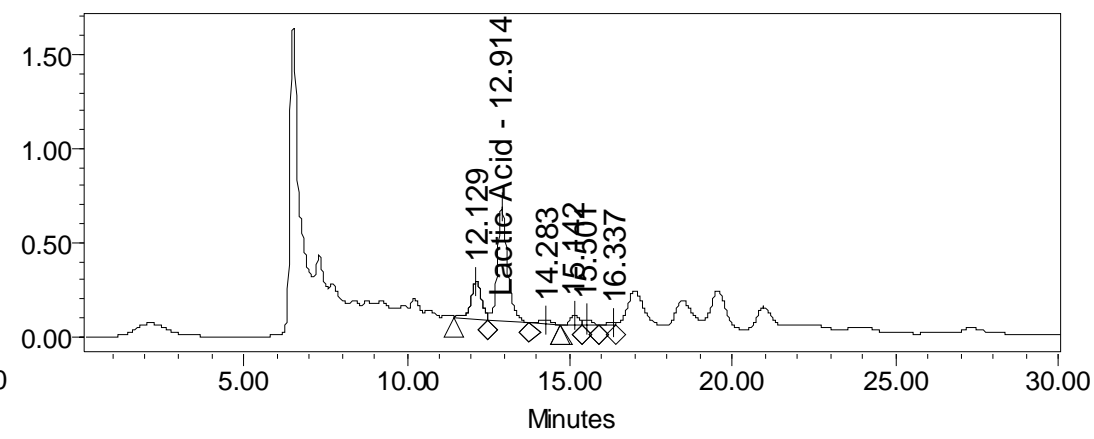

b) YE Media at $\mathrm{T}=69.5 \mathrm{hr}$

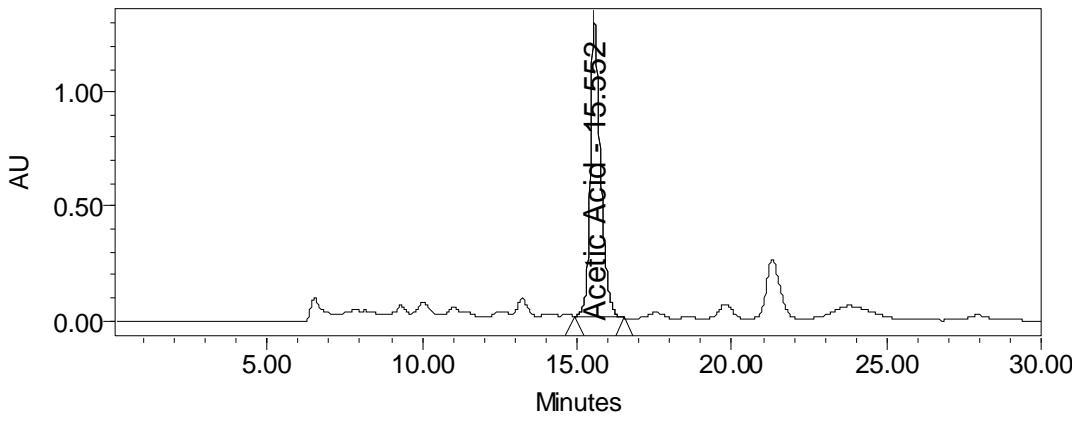

d) CSL Media (100 g/l) at T $=168 \mathrm{hr}$

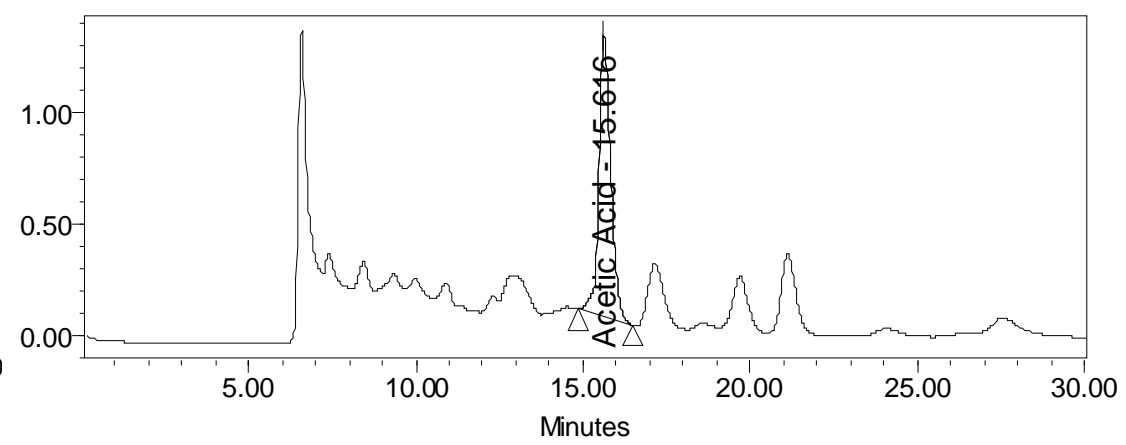


Figure 1.9 - Effect of Corn Steep Liquor on Acetate Production

Corn Steep Liquor (CSL) Concentrations Reported on Wet Basis

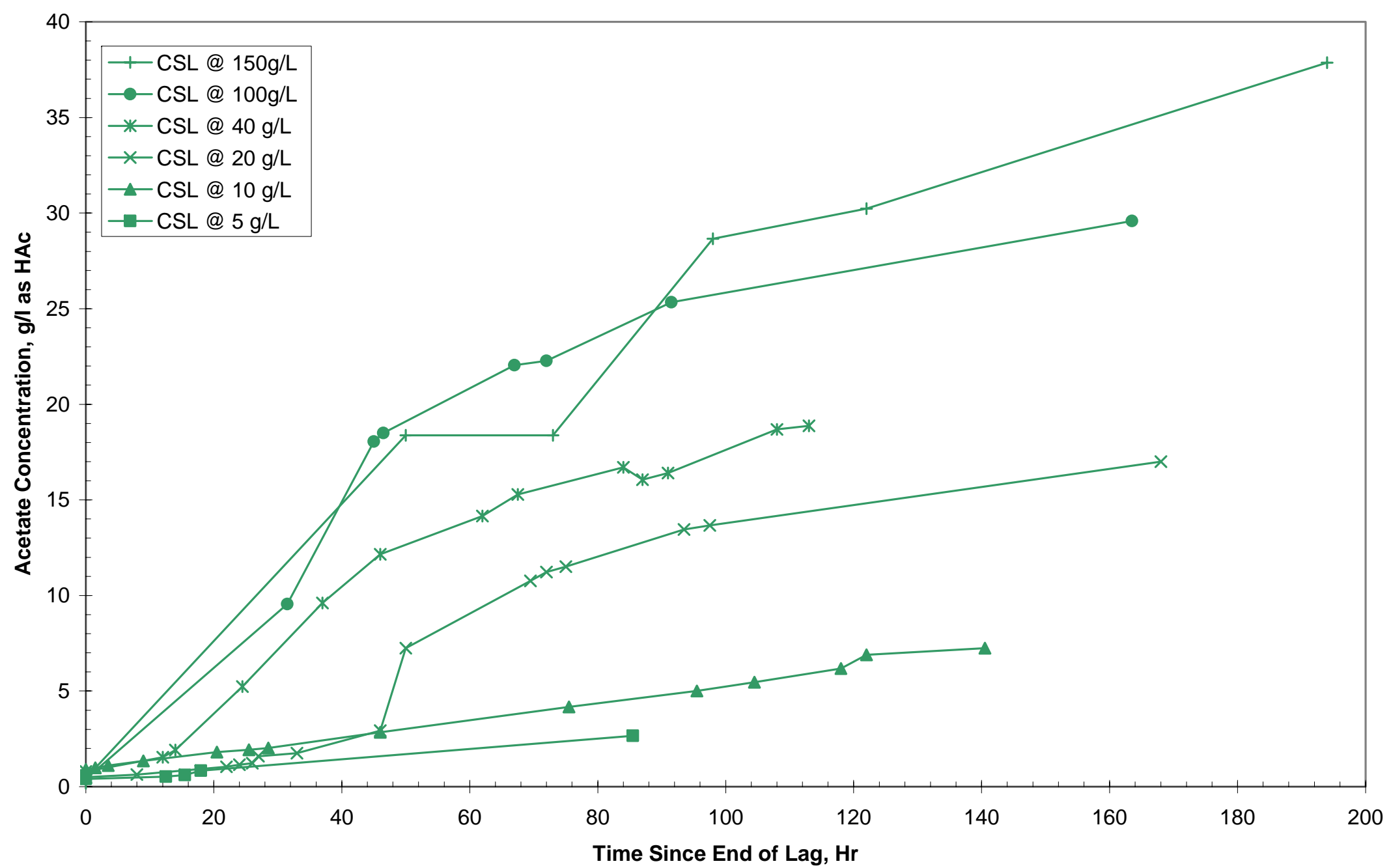


Figure 1.10 - Comparison of Yeast Extract (YE) and Corn Steep Liquor (CSL) Media Corn Steep Liquor Concentrations Reported on Wet Basis

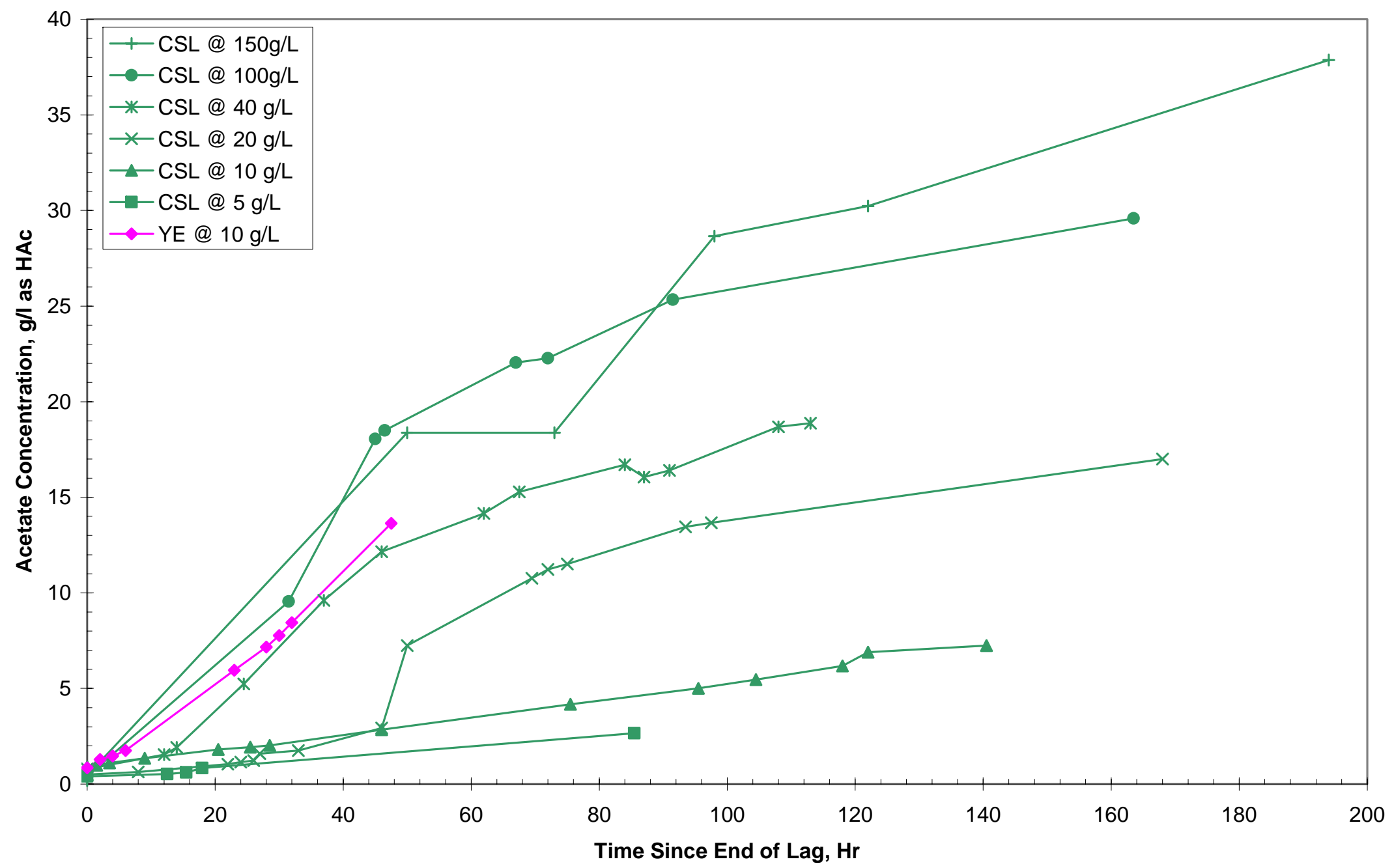


Figure 1.11 - Effect of $\mathrm{CaCO}_{3}$ on Acetate Production in Bottle Cultures

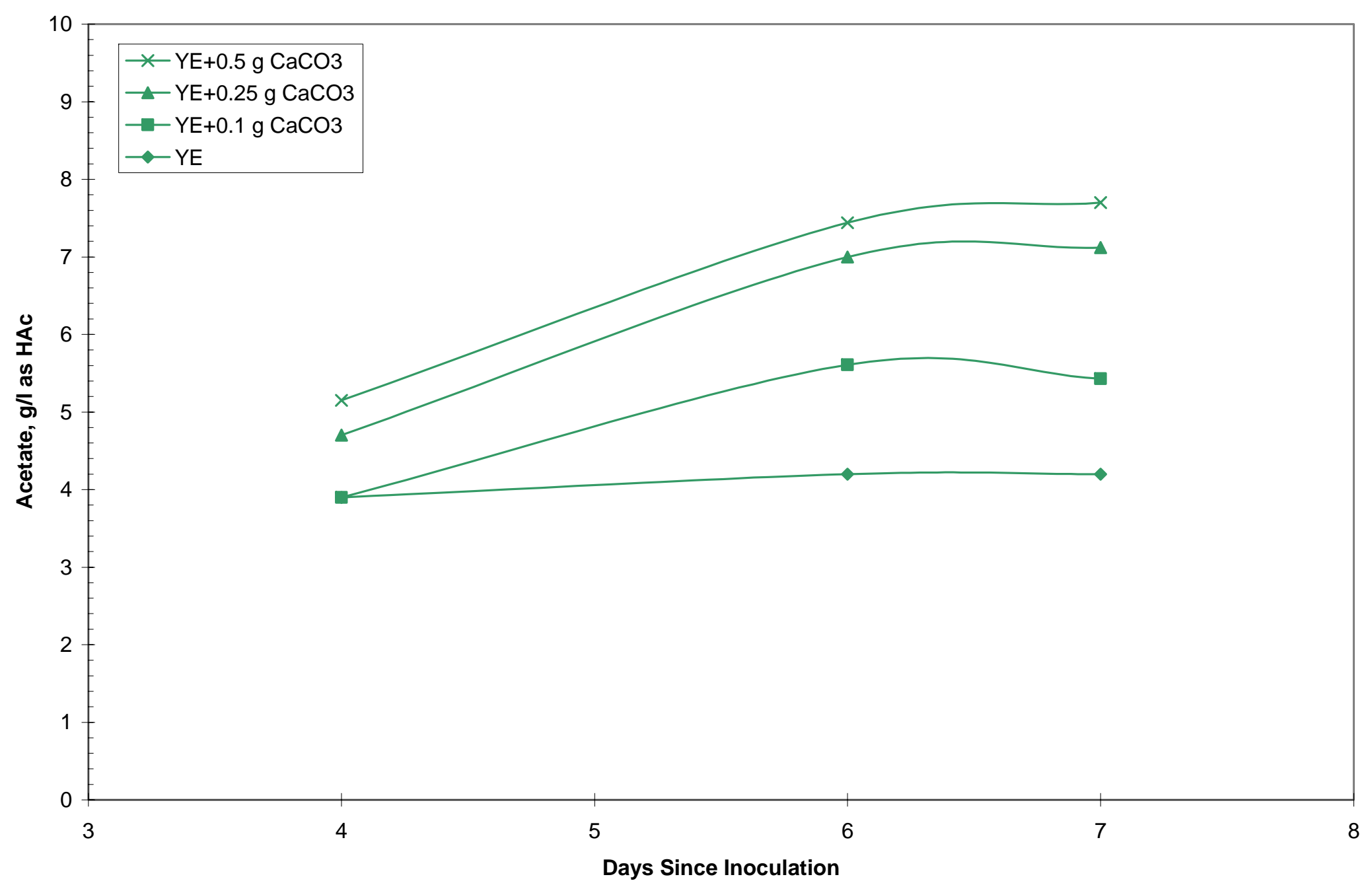




\section{Figure 1.12 - Electrolyte Model for $\mathrm{CO}_{2}+$ Acetic Acid $+\mathrm{CaCO}_{3}$ System}

\section{Equilibrium Relationships:}

Use the relation: $\Delta G=-R T \ln K_{e q}$ and the free energy values in Wagman, D.D., et. al., The NBS Tables of Chemical Thermodynamic Properties, J Phys Ref Data, Vol. II, Supplement No. 2, 1982. Assume $25^{\circ} \mathrm{C}$, presence of a solid $\mathrm{CaCO}_{3}$ phase, and ignore activity coefficient corrections.

1) $\mathrm{H}_{2} \mathrm{O} \Leftrightarrow \mathrm{H}^{+}+\mathrm{OH}^{-}$

$$
\therefore\left[H^{+}\right]\left[\mathrm{OH}^{-}\right]=10^{-14}
$$

2) $\mathrm{CO}_{2}(g)+\mathrm{H}_{2} \mathrm{O} \Leftrightarrow \mathrm{HCO}_{3}^{-}+\mathrm{H}^{+}$

$$
\therefore \log _{10}\left[\mathrm{HCO}_{3}^{-}\right]=-\log _{10}\left[H^{+}\right]-7.8343+\log _{10}\left(P_{\mathrm{CO} 2}\right)
$$

3) $\mathrm{CO}_{2}(g)+\mathrm{H}_{2} \mathrm{O} \Leftrightarrow \mathrm{CO}_{3}{ }^{2-}+2 \mathrm{H}^{+}$

$$
\therefore \log _{10}\left[\mathrm{CO}_{3}{ }^{2-}\right]=-2 \log _{10}\left[H^{+}\right]-18.1638+\log _{10}\left(P_{\mathrm{CO} 2}\right)
$$

4) $\mathrm{Ca}^{2+}+\mathrm{CO}_{3}^{2-} \Leftrightarrow \mathrm{CaCO}_{3}(\mathrm{~s})$

$$
\therefore-8.3042=\log _{10}\left[\mathrm{Ca}^{2+}\right]+\log _{10}\left[\mathrm{CO}_{3}^{2-}\right]
$$

5) $\mathrm{Ca}(\mathrm{OH})^{+}+\mathrm{HCO}_{3}^{-} \Leftrightarrow \mathrm{CaCO}_{3}(\mathrm{~s})+\mathrm{H}_{2} \mathrm{O}$

$$
\therefore-10.6429=\log _{10}\left[\mathrm{Ca}(\mathrm{OH})^{+}\right]+\log _{10}\left[\mathrm{HCO}_{3}^{-}\right]
$$

6) $H A c \Leftrightarrow H^{+}+A c^{-}$

$$
\therefore \log _{10}\left(\frac{\left[A c^{-}\right]}{[H A c]}\right)=-4.7565-\log _{10}\left[H^{+}\right]
$$

7) $\mathrm{Ca}^{2+}+\mathrm{Ac}^{-} \Leftrightarrow \mathrm{CaAc}^{+}$

$$
\therefore 1.1055=\log _{10}\left(\frac{\left[C a A c^{+}\right]}{\left[C a^{2+}\right]\left[A c^{-}\right]}\right)
$$

\section{Acetate Balance:}

8) $C_{t}=[H A c]+\left[A c^{-}\right]+\left[\mathrm{CaAc}^{-}\right]$

\section{Charge Balance:}

9) $2\left[\mathrm{Ca}^{2+}\right]+\left[\mathrm{CaOH}^{+}\right]+\left[\mathrm{CaAc}^{+}\right]+\left[\mathrm{H}^{+}\right]=\left[\mathrm{OH}^{-}\right]+\left[\mathrm{HCO}_{3}{ }^{-}\right]+2\left[\mathrm{CO}_{3}{ }^{2-}\right]+\left[\mathrm{Ac}^{-}\right]$ 
Figure 1.13 - Predicted Effect of Headspace $\mathrm{CO}_{2}$ Partial Pressure on $\mathrm{pH}$

Assumes Presence of Solid $\mathrm{CaCO}_{3}$, Ignores effect of phosphate salts and yeast extract

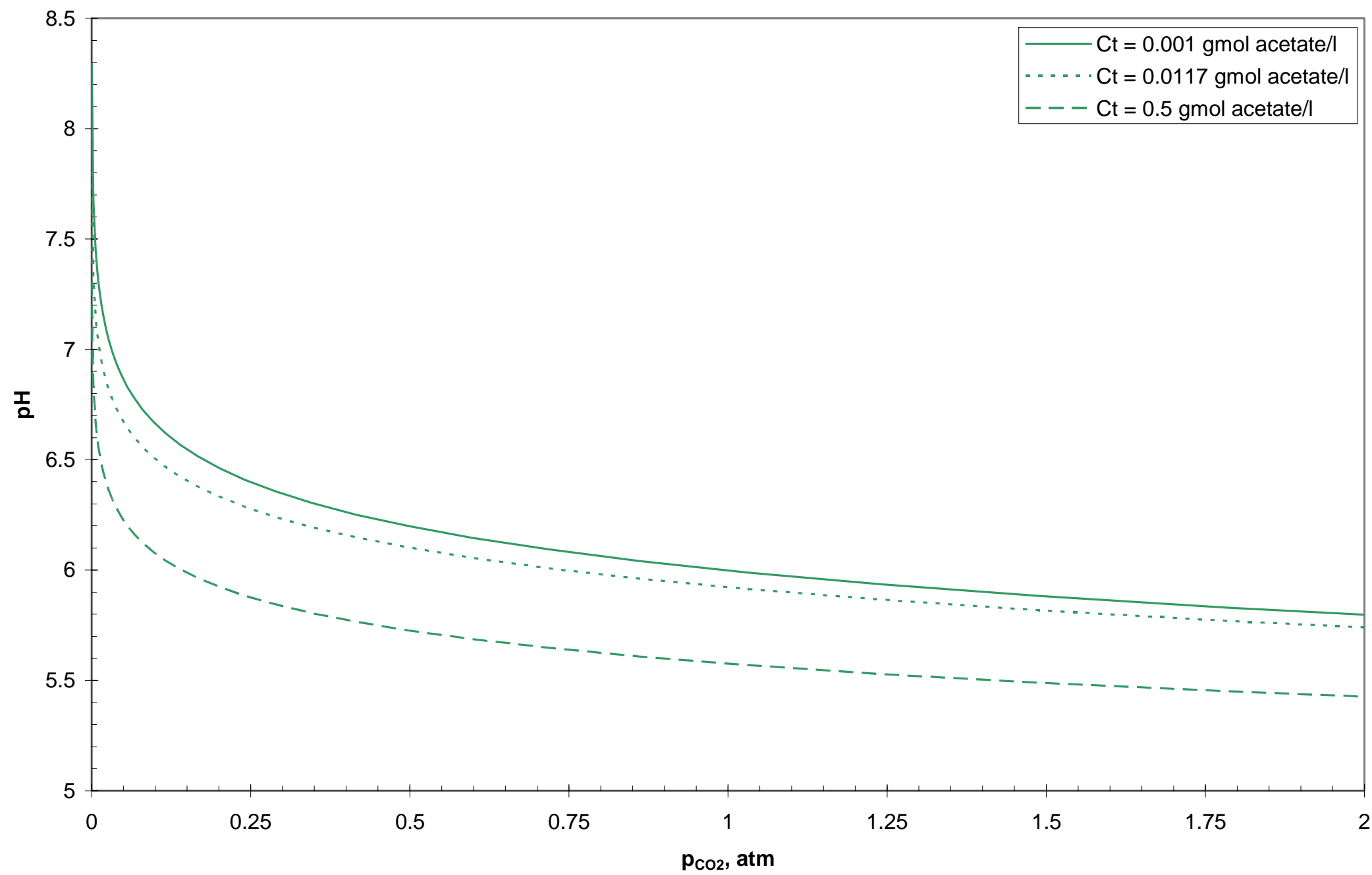



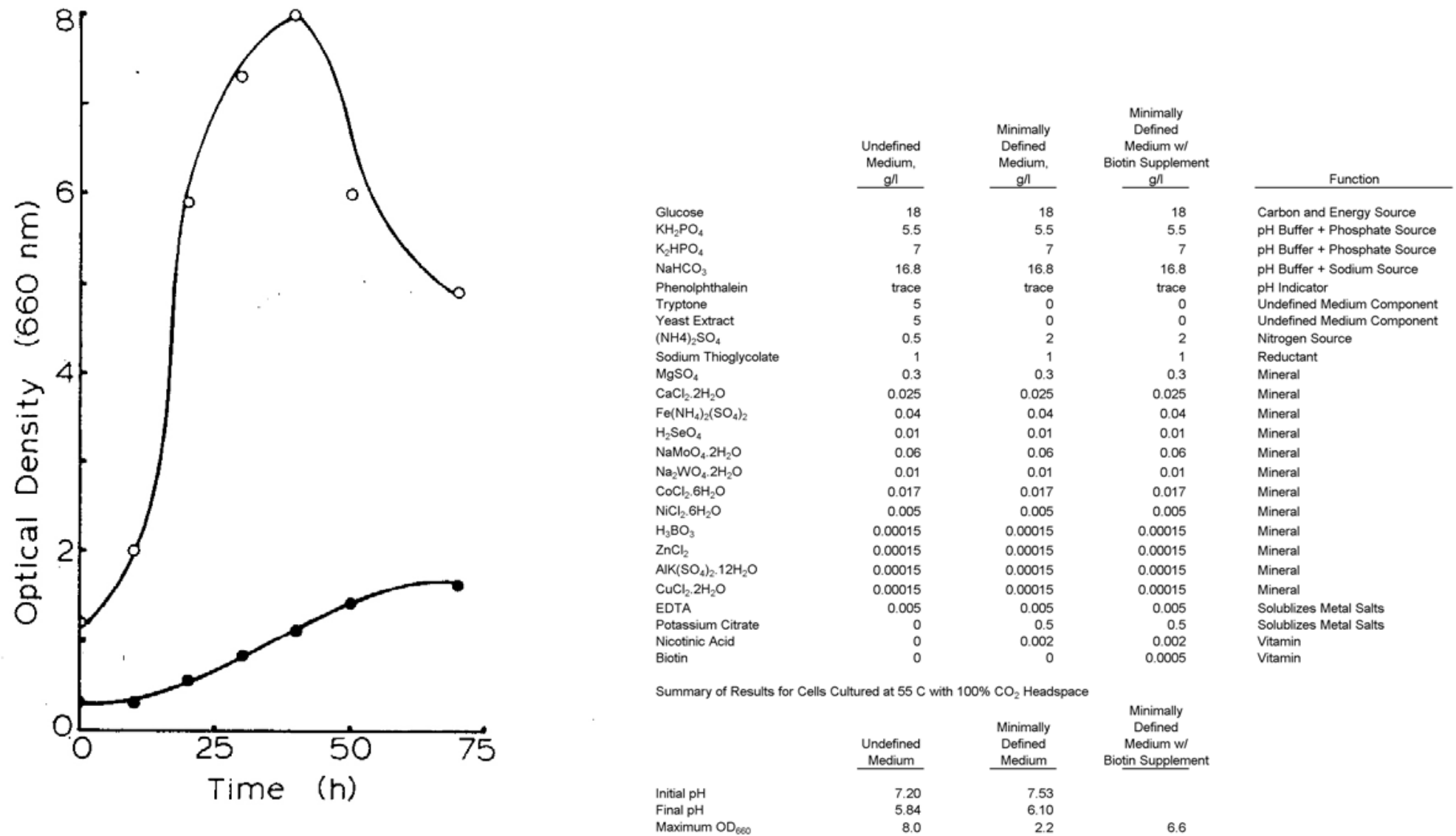

FIG. 2. Growth of UM-maintained cells on UM $(O)$ and MDMmaintained cells on MDM (๑).

Figure 1.14 - Growth Curves for Yeast Extract and Minimally Defined Media for $M$. thermoacetica

Taken from $(27,28)$ 


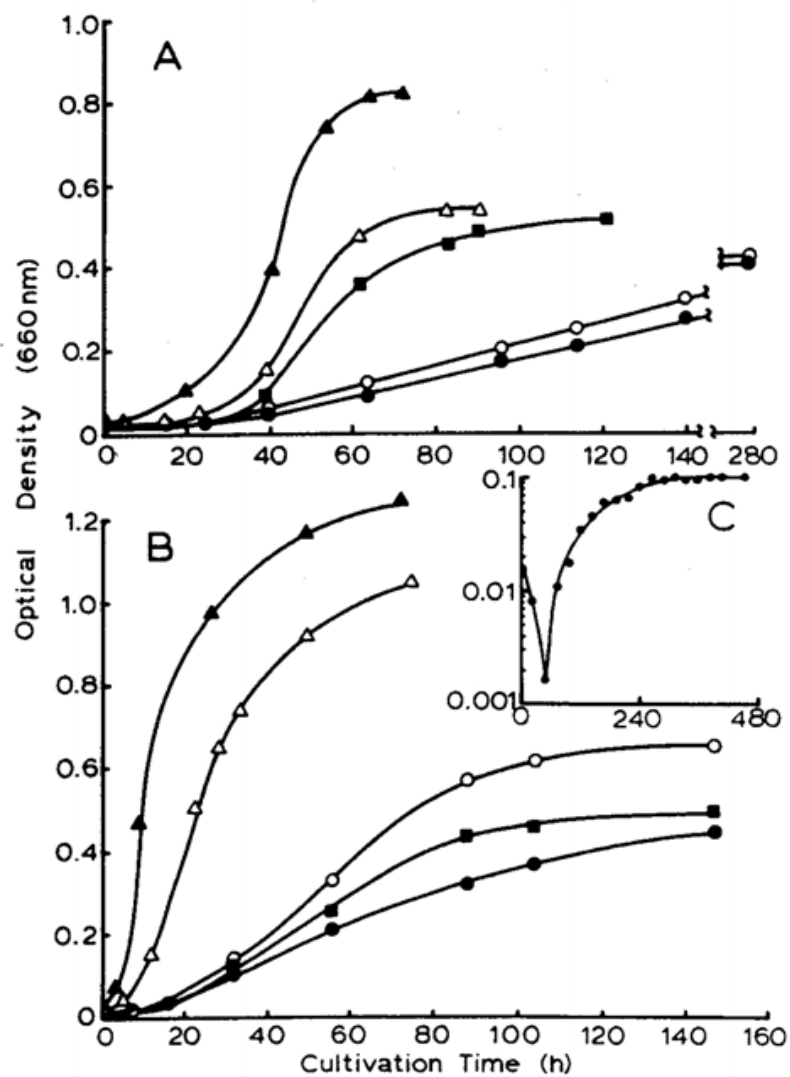

FIG. 1. Growth of C. thermoautotrophicum in UM, DM, and MM. Substrates: methanol. A: glucose. B; $\mathrm{H}_{2}-\mathrm{CO}_{2}$, C. (A and B) Symbols: $\triangle$. UM: $\triangle$. DM: M. MM; . MM minus cysteine: $O$. MM minus cysteine plus biotin (1 mg/iter). Growh profiles are of cultures maintained in each medium for a minimum of 10 sequential transfers, except for the biotin cultures, which were the firs transfers from MM minus cysteine. (C) Growth profile of cultures maintained in $\mathrm{H}_{2}-\mathrm{CO}_{2}-\mathrm{MM}$ for four sequential transfers; no growth was observed in such cultures in the absence of $\mathrm{H}_{2}$.

Figure 1.15 - Growth Curves for M. thermoautotrophicum Taken from (28) 
DE-FG36-03GO13010

ZeaChem, Inc.

Table 1.1 - Selected Literature Results for Acetogenic Fermentations

(Fermentations with M. thermoacetica Unless Otherwise Noted)

\begin{tabular}{|c|c|c|c|c|c|c|c|c|c|}
\hline Configuration & $\begin{array}{l}\text { Primary } \\
\text { Carbon } \\
\text { Source } \\
\end{array}$ & $\begin{array}{l}\text { Primary } \\
\text { Nutrient }\end{array}$ & $\begin{array}{c}\mathrm{pH} \text { and } \\
\text { Base }\end{array}$ & $\begin{array}{c}\text { Initial } \\
\text { Fermentables, } \\
\text { gll }\end{array}$ & $\begin{array}{c}\begin{array}{c}\text { Residual } \\
\text { Fermentables, } \\
\mathrm{g} / 1\end{array} \\
\end{array}$ & $\begin{array}{c}\text { Conversion, } \\
\%\end{array}$ & $\begin{array}{l}\text { Final Acetate } \\
\text { Concentration, } \\
\text { gll (as } H A C) \\
\end{array}$ & References & Comments \\
\hline Batch & $\begin{array}{l}\text { Glucose } \\
\text { Gluose } \\
\text { Glucose } \\
\text { Gluose } \\
\text { Gluosee } \\
\text { Glucose } \\
\text { Gluose } \\
\text { Glucose } \\
\text { Gluosee } \\
\text { Gluose } \\
\text { lylose } \\
\text { Lactate }\end{array}$ & $\begin{array}{l}\text { Yeast Extract+Tryptone } \\
\text { Corn Steeep Liquor } \\
\text { Yeast Extract+ryptone } \\
\text { Yeast Extract+ryptone } \\
\text { Yeast Extract } \\
\text { Hydrolyzed Corn Gluten } \\
\text { Hydrolyzed Soy Flour } \\
\text { Corn Steep Liquor } \\
\text { Ethanol Plant Stillage } \\
\text { Condensed Corm Solubles } \\
\text { Yeast Extract } \\
\text { Yeast Extract+Trypticase }\end{array}$ & $\begin{array}{l}7.0 \mathrm{NaOH} \\
6.9, \mathrm{NaOH} \\
6.6, \mathrm{NaOH} \\
7.1, \mathrm{NaOH} \\
6.5, \mathrm{NaOH} \\
6.5, \mathrm{NaOH} \\
6.5, \mathrm{NaOH} \\
6.5, \mathrm{NaOH} \\
6.5, \mathrm{NaOH} \\
6.5 \mathrm{NaOH} \\
6.8 \mathrm{NaOH} \\
7.0 \mathrm{NaOH}\end{array}$ & $\begin{array}{r}35 \\
46 \\
35 \\
19.6 \\
50 \\
50 \\
50 \\
45 \\
47 \\
15 \\
10.1\end{array}$ & $\begin{array}{r}-0 \\
6 \\
-0 \\
0 \\
0 \\
5 \\
2 \\
5 \\
15 \\
0 \\
0 \\
0\end{array}$ & $\begin{array}{r}100 \\
87 \\
100 \\
100 \\
-90 \\
>90 \\
-90 \\
-70 \\
100 \\
100\end{array}$ & $\begin{array}{r}30 \\
31 \\
29 \\
29 \\
13.1 \\
-37 \\
22 \\
30 \\
30 \\
35 \\
17 \\
15.2 \\
10.1\end{array}$ & 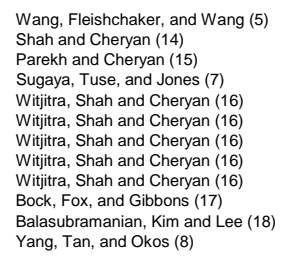 & $\begin{array}{l}\text { Kinetic Study with M. thermoaceticica, Displayed Both Growth and Non-Growth Associated Acetate Production } \\
\text { Fructose AAcculumation OObserved } \\
\text { Improved Strain Also Showed Tolerance for Calcium and Magnesium Salts } \\
\text { Poor Material Balance Closure, Possible Problems with Sugar Carmelization }\end{array}$ \\
\hline Fed Batch & $\begin{array}{l}\text { Glucose } \\
\text { Glucose } \\
\text { Gluose } \\
\text { Glucose } \\
\text { Gluose } \\
\text { xylose } \\
\text { ylose } \\
\text { Gluose } \\
\text { Glucose } \\
\text { Glucose }\end{array}$ & $\begin{array}{l}\text { Yeast Extract+Tryptone } \\
\text { Yeast Extract+ryptonene } \\
\text { Yeast Extract+ryptone } \\
\text { Yeast Extract+Typtone } \\
\text { Condensed Corn Solubles } \\
\text { Yeast Extract } \\
\text { Corn Steep Liquor } \\
\text { Corn Steep Liquor } \\
\text { Yeast Extract } \\
\text { Yeast Extract }\end{array}$ & 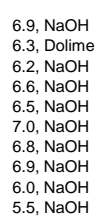 & $\begin{array}{l}20 \\
20\end{array}$ & $\begin{array}{r}5 \\
-5\end{array}$ & -90 & $\begin{array}{l}56 \\
55 \\
53 \\
42 \\
32 \\
42 \\
15 \\
38 \\
30 \\
10\end{array}$ & 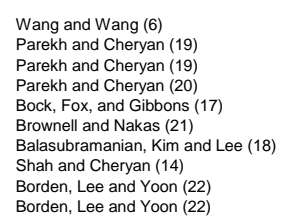 & 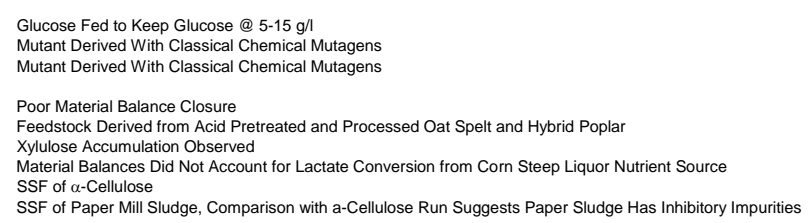 \\
\hline Continuous & Glucose & Yeast Extract+Tryptone & 7.1, $\mathrm{NaOH}$ & 19.6 & -2 & -90 & -12 & Sugaya, Tuse, and Jones (7) & 65 Day Run w/o Contamination \\
\hline Fed Batch w/ Cell Recycle & $\begin{array}{l}\text { Glucose } \\
\text { Glucose } \\
\text { Glucose }\end{array}$ & $\begin{array}{l}\text { Yeast Extract+Tryptone } \\
\text { Yeast Extract+Tryptone } \\
\text { Yeast Extract+Tryptone }\end{array}$ & $\begin{array}{l}\text { 6.8. Dolime } \\
6.8, \mathrm{NaOH} \\
6.1, \mathrm{NaOH}\end{array}$ & 45 & $<5$ & -90 & $\begin{array}{r}102 \\
83 \\
38\end{array}$ & $\begin{array}{l}\text { Parekh and Cheryan (23) } \\
\text { Parekh and Cheryanan (23) } \\
\text { Shah and Cheryan (24) }\end{array}$ & \\
\hline Continuous w/ Cell Recycle & $\begin{array}{l}\text { Glucose } \\
\text { Glucose }\end{array}$ & $\begin{array}{l}\text { Yeast Extract+Tryptone } \\
\text { Yeast Extract+Tryptone }\end{array}$ & $\begin{array}{l}6.8 \mathrm{NaOH} \\
6.1, \mathrm{NaOH}\end{array}$ & $\begin{array}{l}58 \\
45\end{array}$ & $\begin{array}{r}-0 \\
5\end{array}$ & $\begin{array}{r}-100 \\
-90\end{array}$ & $\begin{array}{r}44 \\
37.5\end{array}$ & $\begin{array}{l}\text { Parekh and Cheryan (25) } \\
\text { Shah and Cheryan (24) }\end{array}$ & $\begin{array}{l}\text { Demonstrated } 54 \text { Days of Continuous Operation } \\
\text { Two Stage CSTR with Membrane for Cell Recycle }\end{array}$ \\
\hline Immobilized Cells & $\begin{array}{l}\text { Glucose } \\
\text { Glucose }\end{array}$ & $\begin{array}{l}\text { Yeast Extract } \\
\text { Yeast Extract }\end{array}$ & $\begin{array}{l}\text { 6.95, NaOH } \\
5.0 \text {, Buffered }\end{array}$ & 40 & & & $\begin{array}{r}19 \\
6\end{array}$ & $\begin{array}{l}\text { Wang and Wang (26) } \\
\text { Wiegel et. al. (3) }\end{array}$ & $\begin{array}{l}\text { Also Proved Non-Growth Associated Acetate Production with Chloramphenicol Experiment } \\
\text { Rotary Fermentor }\end{array}$ \\
\hline
\end{tabular}




\section{Table 1.2 - Trace Mineral Solution}

\begin{tabular}{|c|c|}
\hline Component & g/liter \\
\hline EDTA & 0.500 \\
\hline $\mathrm{MgSO}_{4} \cdot 7 \mathrm{H}_{2} \mathrm{O}$ & 3.000 \\
\hline $\mathrm{MnSO}_{4} \cdot \mathrm{H}_{2} \mathrm{O}$ & 0.500 \\
\hline $\mathrm{NaCl}$ & 1.000 \\
\hline $\mathrm{FeSO}_{4} \cdot 7 \mathrm{H}_{2} \mathrm{O}$ & 0.100 \\
\hline $\mathrm{Co}\left(\mathrm{NO}_{3}\right)_{2} \cdot 6 \mathrm{H}_{2} \mathrm{O}$ & 0.100 \\
\hline $\mathrm{CaCl}_{2}$ (anhydrous) & 0.100 \\
\hline $\mathrm{ZnSO}_{4} \cdot 7 \mathrm{H}_{2} \mathrm{O}$ & 0.100 \\
\hline $\mathrm{CuSO}_{4} \cdot 5 \mathrm{H}_{2} \mathrm{O}$ & 0.010 \\
\hline AlK $\left(\mathrm{SO}_{4}\right)_{2}$ (anhydrous) & 0.010 \\
\hline $\mathrm{H}_{3} \mathrm{BO}_{3}$ & 0.010 \\
\hline $\mathrm{Na}_{2} \mathrm{MoO}_{4} \cdot 2 \mathrm{H}_{2} \mathrm{O}$ & 0.010 \\
\hline $\mathrm{Na}_{2} \mathrm{SeO}_{3}$ (anhydrous) & 0.001 \\
\hline $\mathrm{Na}_{2} \mathrm{WO}_{4} \cdot 2 \mathrm{H}_{2} \mathrm{O}$ & 0.010 \\
\hline $\mathrm{NiCl}_{2} \cdot 6 \mathrm{H}_{2} \mathrm{O}$ & 0.020 \\
\hline
\end{tabular}




\section{Table 1.3 - Description of Fermentation Runs}

All fermentations were carried out at an initial [glucose] of $50 \mathrm{~g} / \mathrm{L}$.

\section{Fermentation Run}

1

2

3

4

5

7

8

9

10

11
Initial [Nitrogen]

Ru

5g/L Y.E.

5g/L CSL (Sigma)

$168 \mathrm{~h}$

96h

10g/L CSL (Sigma)

$168 \mathrm{~h}$

20g/L CSL (Sigma)

$168 \mathrm{~h}$

40g/L CSL (Sigma)

$70 \mathrm{~h}$

40g/L CSL (Sigma) 119h

80g/L CSL (Sigma)

$168 \mathrm{~h}$

80g/L CSL (Sigma)

40g/L CSL (CP)

$118 \mathrm{~h}$

10g/L Y.E.

$10 \mathrm{~g} / \mathrm{L}$ Y.E.

$11 \mathrm{~g} / \mathrm{L}$ YE

10g/L Y.E.

10g/L Y.E.

10g/L Y.E.

10g/L Y.E.

10g/L Y.E.

$100 \mathrm{~g} / \mathrm{L} \mathrm{CSL}$

$150 \mathrm{~g} / \mathrm{L} \mathrm{CSL}$

240

150g/L CSL

$91 \mathrm{~h}$

\section{Final [Acetate]}

$28 \mathrm{~g} / \mathrm{L}$

Maximum rate $=0.25 \mathrm{~g} / \mathrm{L}-\mathrm{h}$

$2.5 \mathrm{~g} / \mathrm{L}$

This run never took off. Low nitrogen availability/concentration (?)

$7.5 \mathrm{~g} / \mathrm{L}$

$17 \mathrm{~g} / \mathrm{L}$

$10 \mathrm{~g} / \mathrm{L}$

$19 \mathrm{~g} / \mathrm{L}$ $2 \mathrm{~g}$ phosphate. The rate of Acetate production increased following addition of the CSL, however, the Hlac peak increased also. Shutdown run-contaminated $\mathrm{w} / \mathrm{lab}(?)$.

$21.5 \mathrm{~g} / \mathrm{L}$

At $124 \mathrm{~h}$, added $10 \mathrm{~g} / \mathrm{YE}$ in water. The rate of acetate production increased from the prior $12 \mathrm{~h}(0)$ to $\sim 0.1 \mathrm{~g} / \mathrm{L}-\mathrm{h}$.

Run terminated after $36 \mathrm{~h}$ due to mechanical malfunction; $\mathrm{pH}$ controller/pump problem.

$12.7 \mathrm{~g} / \mathrm{L}$

$19 \mathrm{~g} / \mathrm{L}$

9g/L $23 \mathrm{~g} / \mathrm{L}$

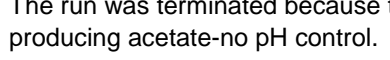

Contaminated. Determined that neck of fermentor was cracked. Sent back for repair.

Contaminated run.

$600 \mathrm{ml}$ run in small fermentor, utilizing $\mathrm{CaCO} 3$.

Poor pH control. pH went to 7.8 after $24 \mathrm{~h}$.

Run terminated

$600 \mathrm{ml}$ run in small fermentor.

Poor $\mathrm{pH}$ control. pH went to 7.8 after $24 \mathrm{~h}$.

Run terminated

$22 \mathrm{~g} / \mathrm{L}$

This was the first run following repair of the fermentor. At $46 \mathrm{~h}, 97 \%$ conversion efficiency.

$10 \mathrm{~g} / \mathrm{L}$

Terminated after $44 \mathrm{~h}$ after fermenter prove to be running o.k. At $44 \mathrm{~h}$, acetate production $\sim=$ to $44 \mathrm{~h}$ on $40 \mathrm{~g} / \mathrm{L} \mathrm{CSL}$.

Best run recorded. Between T30 and T70 the rate of acetate production was $\sim 0.5 \mathrm{~g} / \mathrm{L}-\mathrm{h}$. At one point, acetate production was $\sim 0.7 \mathrm{~g} / \mathrm{L}-\mathrm{h}$.

$38 \mathrm{~g} / \mathrm{L}$

The lag period was $\sim 72 \mathrm{~h}$. If you back out the 72 hour lag, it puts the run at $168 \mathrm{~h}$.

13g/L The lag period was $\sim 72 \mathrm{~h}$. Ran out of $\mathrm{CO} 2$. 


\section{Task 2 - Esterification Step}

\section{Background}

A wide range of organic acids can potentially be produced by fermentation using known micro-organisms, yet today nearly all organic acids are produced by synthetic means. Some reasons why fermentation based routes have not been competitive with synthetic routes are related to the technical difficulties associated with recovery of organic acids from fermentation broths. Three common technical issues:

i) High purity specifications for the final product.

ii) Energy efficient means of handling the dilute broths.

iii) Avoidance of the co-production of stoichiometric amounts of salts and other wastes.

have to be addressed to enable commodity scale production of organic acids via fermentation.

Micro-organisms capable of producing organic acids are often product inhibited and inhibited by low $\mathrm{pH}$. In order to achieve high yields, the $\mathrm{pH}$ of the fermentation step has to be kept near neutral by the addition of a base such as ammonia, sodium hydroxide/carbonate or calcium hydroxide/carbonate. Thus fermentation routes typically produce a dilute aqueous solution of the organic acid salt rather than the organic acid in its protonated form. The salts are highly water soluble, have a negligible vapor pressure and carbonyl group is unreactive. These properties make recovery of the salt difficult since distillation, extraction, crystallization and other common industrial separation methods for large scale production are either technically or economically infeasible.

One way to ease the recovery of organic acid salts is to add a mineral acid to lower the $\mathrm{pH}$ of the broth, thereby converting the organic acid into its protonated form. In its protonated form the organic acid can be more easily recovered by known means such as distillation, extraction or reactive separation processes. Direct acidification with a mineral acid is usually regarded as a troublesome option for recovery of organic acid salts because a salt byproduct is inevitably formed. This byproduct is often of very low value. For example, calcium sulfate in the form of gypsum is historically the salt co-produced during lactic acid recovery (1).

$$
\text { Calcium Lactate + Sulfuric Acid } \rightarrow \text { Lactic Acid + Calcium Sulfate }
$$

Gypsum markets either have to be found or an environmentally responsible disposal method has to be identified. Because of these limitations, much research has gone into alternative methods to recover lactic acid including: 1) careful selection of cations and anions to give a more desirable salt co-product such as ammonium sulfate (2), 2) recovery schemes that include the use of weakly acidic ion exchange resins to reduce the amount of salt co-product $(3,4), 3)$ recovery schemes based on the thermal decomposition of the ammonium organic acid salt $(5,6) 4$ ) the use of bipolar electrodialysis (7), and 5) use of carbon dioxide as an acidulant along with the formation of an amine complex in a reactive extraction process (8). 
Recovery of fermentation derived acetate has been summarized by Busche and coworkers at Du Pont $(9,10)$, Partin and Heise (11) and Eggeman and Verser (12). Here we focus on the work of Urbas at CPC International $(13,14)$. Urbas used carbon dioxide for acidification and amine complexes for the recovery of acetic acid. Tributylamine (TBA) is normally immiscible with water, but the tributyl amine:acetic acid complex (TBA:HAc) is water soluble. When a dilute aqueous solution of calcium acetate at near neutral $\mathrm{pH}$ is mixed with tributyl amine, and then carbon dioxide is bubbled through the mixture, the following reaction occurs at near ambient temperatures:

$$
\mathrm{Ca}(\mathrm{Ac})_{2}+\mathrm{H}_{2} \mathrm{O}+\mathrm{CO}_{2}+2 \mathrm{TBA} \rightarrow 2 \mathrm{TBA}: \mathrm{HAc}+\mathrm{CaCO}_{3}
$$

Use of a stoichiometric amount of tributyl amine produces a single liquid phase containing the tributyl amine:acetic acid complex. The reaction is driven to the right since calcium carbonate precipitates upon formation.

In one embodiment of the Urbas patents, the aqueous amine complex is extracted into an organic solvent, the solvent is stripped off, and the complex is thermally split apart giving the acetic acid product and regenerating both the solvent and amine for recycle. Urbas preferred the use of low boiling, non-reactive solvents that do not azeotrope with acetic acid, with preference for chloroform because of a favorable distribution coefficient for the extraction step. We have found the thermal regeneration reaction is difficult in practice, leading to a viscous intractable residue and low yield of acetic acid. Furthermore, use of chlorinated solvents such as chloroform, would be problematic at industrial scale.

The work of this grant covers a new scheme for recovery of the amine complex from the aqueous solution. The amine complex is extracted with an alcoholic solvent followed by esterification and distillation of the organic extract. During esterification, the reaction:

$$
T B A: H A c+R O H \rightarrow T B A+R A c+H_{2} \mathrm{O}
$$

produces the ester directly from the amine complex. The reaction is pulled to the right by continuous removal of water. After completion of the esterification step, the ester is isolated by distillation and the excess alcohol and amine are recycled. The acetate ester can either be sold as a final product or undergo further chemical transformations such as hydrogenolysis to produce ethanol.

\section{Methods and Materials}

Materials - Laboratory de-ionized water was used for creating all aqueous feed stocks. Instrument grade $\mathrm{CO}_{2}$ was used for acidification. All other materials were ACS reagent or standard commercial grades.

Analytical Methods - Concentrations of the amine complex in both aqueous and organic solutions were determined by potentiometric titration of $10-20 \mathrm{ml}$ samples diluted with $30 \mathrm{ml}$ of methanol and titrated with standardized $\mathrm{KOH}$ in methanol following the method of Ricker, et. al. 
(15). For the solvent screening experiments, the water content of the organic phase was determined by addition of excess toluene to a weighed sample of the organic phase. The resultant water phase was recovered, weighed, and water content of the original sample calculated by mass balance.

For the more detailed phase diagram experiments, careful measurements were made of the phase volumes and phase densities and these values were used in the calculations for data analysis. The density of each phase was determined by weighing a known volume of each phase determined using a volumetric pipette. Concentration of the complex in the organic phase was again determined by titration. The water content of the solvents and organic extracts were measured by Karl Fischer analysis at an outside lab. Residual alcohol in the water phase was estimated using the solubility of the pure alcohol in pure water as the basis. Binary liquid-liquid equilibrium data for alcohols and water are given in (16).

Acidification Experiments - $500 \mathrm{ml}$ of an aqueous calcium acetate solution (50 g/l as acetate) were added to a 1 liter graduated cylinder and the $\mathrm{pH}$ was adjusted to 6.9-7.0 using acetic acid. A 5\% molar excess of TBA was added, then the solution was sparged with $\mathrm{CO}_{2}$ for 30 minutes at ambient pressure. The solution was filtered, the $\mathrm{CaCO}_{3}$ cake was washed once with water, washed again with acetone, dried and then weighed.

Extraction Experiments - All extraction experiments were conducted at room temperature (25 ${ }^{\circ} \mathrm{C}$ ). For solvent screening with TBA as the amine, $100 \mathrm{~g}$ of an aqueous mixture containing 4.08 $\mathrm{g}$ of acetic acid (HAc) and $12.56 \mathrm{~g}$ of TBA were mixed in a separatory funnel with $100 \mathrm{~g}$ of organic solvent. The mixture was shaken by hand and then allowed to separate. Each phase was recovered and weighed. Samples were taken and analyzed for TBA:HAc and water. A similar procedure was used for the tie-line experiments with n-pentanol or n-hexanol as the extractant except the starting concentration of TBA:HAc was varied to generate several tie-lines.

The solvent screening experiments with N,N-diisopropylethylamine started with an aqueous solution made from $200 \mathrm{~g}$ of water, $9.95 \mathrm{~g}$ of acetic acid, and $20.85 \mathrm{~g}$ of the amine. An equal weight of the aqueous mixture and organic solvent were added to a separatory funnel, the solutions were gently shaken, settled, separated and analyzed.

Esterification Experiments - The esterification reactions were conducted at atmospheric pressure ( 630 $\mathrm{mm} \mathrm{Hg}$ at our lab in Colorado) in a glass still consisting of a electric heating mantle, a 1 liter round bottom flask, a vacuum jacketed $30 \mathrm{~cm}$ distillation column packed with $4 \mathrm{~mm} \times 4 \mathrm{~mm}$ glass rings, and an overhead condenser and product splitter allowing the removal of a variable amount of distillate and return of reflux to the column. Figure 2.1 is a photo of the laboratory apparatus.

$450 \mathrm{~g}$ of a room temperature solution containing a 3:1 molar ratio of alcohol to TBA:HAc complex were added to the still. The catalyzed run with n-hexanol included $\mathrm{H}_{2} \mathrm{SO}_{4}$ in the starting solution at a 0.1:1 mole ratio with respect to the TBA:HAc complex. The heating mantle was turned on and approximately thirty minutes later the solution began to boil. Water formed a second phase in the overheads as the reaction progressed. The water was collected and the volume recorded over time. Conversion was estimated as the percent of the maximum 
theoretical water if all of the acetic acid were converted to ester and confirmed by titration of residual TBA:HAc in the still pot samples.

\section{Results}

\section{Acidification Experiments}

Two distinct liquid phases were formed when tributyl amine was mixed with the aqueous calcium acetate solution. As soon as the flow of $\mathrm{CO}_{2}$ was started, the mixture became cloudy and as the reaction continued solid $\mathrm{CaCO}_{3}$ was seen in the mixture. The mixture also gradually changed to a single liquid phase with $\mathrm{CaCO}_{3}$ particles suspended by the gas flow. The acidification experiments were conducted four times with $\mathrm{CaCO}_{3}$ yields ranging from 91.0$96.1 \%$ of theoretical. The resulting $\mathrm{CaCO}_{3}$ precipitates were easy to filter and wash. A fine white powder was generated in all cases.

Several variations of the experiment were also conducted:

1) The $\mathrm{CO}_{2}$ blown through the solution was replaced with a $\sim 10: 1$ mixture of $\mathrm{N}_{2}$ and $\mathrm{CO}_{2}$. Although this change resulted in a slightly slower reaction, the experiment still produced copious quantities of the $\mathrm{CaCO}_{3}$ precipitate. This result suggests the rate of reaction is related to the partial pressure of carbon dioxide.

2) The tributyl amine was replaced with a stoichiometric amount of N,NDiisopropylethylamine (DIEA, also known as Hunig's base). The reaction appeared to proceed faster when compared to the reaction with tributyl amine. Copious quantities of the $\mathrm{CaCO}_{3}$ precipitate were formed.

3) The tributyl amine was replaced with a stoichiometric amount of trioctyl amine. No reaction occurred; $\mathrm{No} \mathrm{CaCO}_{3}$ precipitate was formed. The results of this experiment agree with the prior work of Urbas $(13,14)$.

\section{Extraction Experiments}

Primary separation was achieved quickly ( $<30$ seconds) for all solvents included in the solvent extraction screening experiments. Secondary separation was also very quick for all solvents, only taking a few minutes to obtain clear solutions in both phases. Table 2.1 reports the distribution coefficients and selectivities. The distribution coefficient, $\mathrm{K}_{\mathrm{D}}$ - defined as the ratio of the mass fraction of TBA:HAc in the organic phase divided by the mass fraction of TBA:HAc in the aqueous phase, is a measure of the concentrating power of the solvent. Selectivity, defined as the distribution coefficient times the ratio of the mass fraction of water in the aqueous phase divided by the mass fraction of water in the organic phase, is a measure of the solvent's ability to preferentially separate the TBA:HAc complex from water. Higher selectivity implies that less water is dragged along into the organic extract, which in turn means that less energy is needed to remove free water in the downstream esterification step. 
Solvents were chosen to represent various classes. Esters, aromatics and ketones were all found to have a low distribution coefficient in the solvent screening experiments. Our results with chloroform essentially agree with the prior work of Urbas, but as mentioned earlier, the use of chlorinated solvents at the industrial scales required for fuel ethanol production would be problematic. The best solvent class appears to be the higher molecular weight alcohols. Within the alcohols, there is a trade-off between distribution coefficient and selectivity. Low molecular weight alcohols have more a favorable distribution coefficient, but the mutual solubility of water with the low molecular weight alcohol lowers selectivity. Both n-pentanol and n-hexanol have favorable distribution coefficients and high selectivity.

Figure 2.2 presents the experimentally measured liquid-liquid equilibria for the water + TBA:HAc + n-pentanol system at $25^{\circ} \mathrm{C}$. Also shown are the predictions from HYSYS's Generalized NRTL activity coefficient model where the interaction parameters were obtained by regression of the experimental data. The agreement between the experimental values and the generalized NRTL model is quite good. The shape of the two phase region was experimentally checked by titration of several TBA:HAc + n-pentanol mixtures with water, and by titration of several TBA:HAc + water mixtures with n-pentanol (data not shown). The results of these titrations qualitatively confirmed the HYSYS predictions. We do not include these data with Figure 2.2 since our titrations tended to overshoot the two phase cloud point; their inclusion reduces the clarity of Figure 2.2.

Figure 2.3 presents the experimentally measured liquid-liquid equilibria for the water + TBA:HAc + n-hexanol system at $25^{\circ} \mathrm{C}$. The distribution coefficients are lower for n-hexanol when compared to n-pentanol, but the n-hexanol system does have a slight advantage in selectivity as illustrated by the lower water contents of the organic phases.

In both Figures 2.2 and 2.3, the two phase region is fairly broad and the tie-lines have a favorable slope. Distribution coefficients become more favorable at higher TBA:HAc concentrations, which leads to a concave-up equilibrium line when the data are plotted as mass fraction TBA:HAc in the organic layer (y axis) vs. mass fraction TBA:HAc in the aqueous layer (x axis). Nonetheless, as shown later in Task 3, a good process design will avoid the potential pinch between the equilibrium curve and the operation line and requires only a few stages to produce a concentrated TBA:HAc extract from a dilute aqueous solution.

The results of the initial solvent screening experiments and the phase diagram data in Figures 2.2 and 2.3 differ, with the phase diagram experiments giving lower distribution coefficients than observed in the initial solving screening experiments. Data analysis for the phase diagram experiments included corrections for the phase volume change and phase densities, thus the phase diagram results are of higher accuracy than the initial solvent screening experiments.

The observed distribution coefficients for the solvent screening experiments with N,Ndiisopropyethylamine were 0.092 with n-pentanol and 0.0487 with n-hexanol as the solvent. This amine is slightly more water soluble than TBA, so the fall-off in distribution coefficient was not surprising. No further work was pursued with this amine. 


\section{Esterification Experiments}

The extracts produced by mixing the alcohols with the acid amine complex in water contain a small amount of water depending on the alcohol used. This free water is removed by azeotropic distillation using the alcohol itself as the drying solvent for the extract producing a dry solution of the amine complex in the alcohol solvent. Alcohols in the range of interest form heterogeneous azeotropes with water allowing easy separation of the water from the distillate. After the extract is dried, the reaction is continued, and there is a continuous slow production of water overhead in the still from the esterification reaction. The overhead splitter is configured so that the water is removed continuously as it is produced and the solvent is returned to the still as reflux.

Figure 2.4 plots the water generated during esterification and reports the observed range of pot temperatures during the time the solutions were boiling. The pot temperature rose over time, further evidence of reaction. The curves in Figure 2.4 are useful for comparing rates, but can only be qualitatively used to compare yield since different molar amounts of TBA:HAc were present in the starting solutions, differing amounts of materials were taken for samples over the course of the experiment, and the starting solvents had different levels of initial free water. The conversion values in Table 2.2, estimated from the water production and confirmed by titration, are more useful for comparing yields.

Both esterification rate and yield increased with increasing molecular weight of the alcohol. Rather than being related to the chain length of the alcohol, this improvement in performance was probably caused by the higher boiling point and thus higher reaction temperature for the higher molecular weight alcohols. Adequate esterification rate and yield could probably be achieved with the lower molecular weight alcohols if the reaction was conducted at elevated pressure. The pressures required are not extreme. For example, n-butanol will boil at $170{ }^{\circ} \mathrm{C}$ and $482.6 \mathrm{kPa}$, well within the range of industrial importance.

Esterification rate and yield can also be improved by using a catalyst. Comparison of the non-catalyzed n-hexanol run with the catalyzed run shows that sulfuric acid is potentially a good catalyst, although the ultimate fate of any homogeneous catalyst has to be worked out for any potential industrial process. Solid catalysts, both Brønsted and Lewis acids, may be easier to work with since catalyst recovery is not an issue.

\section{Discussion}

We selected n-pentanol as the extraction and esterifying alcohol for the work of Task 3. The extraction performance of n-pentanol it is a good compromise between distribution coefficient and selectivity. The esterification rate should be reasonable provided the reaction is operated at slight pressure.

Figure 2.5 is a simplified process sketch of the proposed recovery process. A clarified broth containing calcium acetate is fed to the acidification step where the aqueous TBA:HAc complex is formed. Next the precipitated calcium carbonate is removed by filtration and recycled for use as the neutralizing base in fermentation. The TBA:HAc complex is then 
extracted from the filtrate using n-pentanol as the solvent. The extract is esterified. It is further fractionated to give a stream rich in n-pentyl acetate/n-pentanol and a recycle stream of TBA. During our modeling efforts in Task 3 we found that the fractionation of n-pentyl acetate and npentanol is difficult. It is more efficient to send the entire mixture downstream to hydrogenolysis. The hydrogenolysis step regenerates the n-pentanol used in the extraction step and also produces the desired ethanol product. While the surrounding fermentation, hydrogenolysis and water treatment steps required for a fully integrated system are not shown in Figure 2.5, these steps are included in the model discussed later in Task 3.

The proposed process addresses all three technical issues for organic acid recovery outlined in the Background section for this task. The combination of extraction and fractionation generates a high purity product since the desired compound, in this case the n-pentyl acetate intermediate, is selectively transferred from one phase to another in each of the unit operations leaving behind undesired impurities. Extraction is an energy efficient means for removing the TBA:HAc complex from a dilute broth without having to boil large amounts of water. Finally, no net salt co-product is generated since the calcium carbonate produce in the recovery step is used as the neutralizing base for fermentation. A well integrated fermentation and recovery scheme results from our systems level approach.

\section{Sub-Task Review}

The description of the sub-tasks, taken from Appendix B Statement of Work in the original proposal, is repeated below:

Task 2.1 Analytical Method Validation - Published analytical HPLC methods for measuring ethanol, acetic acid and ethyl acetate will be implemented and validated on our equipment. The outcome of this task will be the ability to accurately measure the levels of these species in samples produced by our later experimental runs.

Task 2.2 Construction - A fully instrumented 1 liter batch pressure reactor suitable for conducting the acidification and esterification reactions will be assembled. A laboratory scale microfiltration unit will also be assembled and shakedown runs for clarifying fermentation broth will be conducted. The ability to generate reproducible runs with good mass balance closure will be demonstrated prior to further experimental work. The outcome of this task will be the assembly and shakedown of equipment needed for Tasks 2.3 and 2.4.

Task 2.3 Testing - Acidification - A series of batch acidification runs will be conducted to study the effects of key process variables on the yield of acidified acetic acid from clarified fermentation broth. Partial pressure of $\mathrm{CO}_{2}$, acetate to amine mole ratio and amine selection will be among the variables studied. The need for any additional pretreatment of the broth, such as nanofiltration, will be established. Regeneration of the amine per the method outlined in $(13,14)$ will also be verified. Runs that do not exhibit good mass balance closure will be discarded and the conditions repeated with another run. The outcome of this task will be a set of high quality experimental data that can be used for model development. 
Task 2.4 Testing - Esterification - In parallel with the acidification experiments, a series of batch esterification runs on acidified fermentation broth will be conducted to collect the data required for a kinetic model of the esterification step. Concentration and temperature will be among the key variables studied. Runs that do not exhibit good mass balance closure will be discarded and the conditions repeated with another run. The outcome of this task will be a set of high quality experimental data that can be used for model development.

Task 2.5 Data Analysis - The data from Tasks 2.3 and 2.4 will be processed into forms that can be used for further modeling efforts in Task 3.1.

The following discussion compares the work actually accomplished against the original proposal subtasks:

Task 2.1 Analytical Method Validation - We found that HPLC would be a poor choice of analytical methods for our work since amines, such as tributyl amine and the TBA:HAc complex, are poisons for many HPLC columns. We tried some quantitative analyses based gas chromatographic separations, with marginal success. We eventually found that all of our analytical needs could be satisfied by titration of the amine complex according to the method of Ricker (15), supplemented with water determinations either using toluene as an anti-solvent or by Karl Fischer titrations performed at an outside lab.

Task 2.2 Construction - We found that good yields for the acidification step could be obtained at atmospheric pressure, obviating the need for a pressure vessel for the acidification experiments. The effect of pressure on the esterification experiments can be inferred from Figure 2.4. Thus, all of the information of interest was obtained using standard laboratory glassware.

Task 2.3 Testing - Acidification - Complete. Regeneration of the amine per the method of Urbas $(13,14)$ was not performed since we could not reproduce the prior thermal splitting step, as discussed in the Background section.

Task 2.4 Testing - Esterification - Complete.

Task 2.5 Data Analysis - Complete.

\section{References}

1) Holten, C.H., Lactic Acid: Properties and Chemistry of Lactic Acid and Derivatives, Verlag Chemie, 1971.

2) Cockrem, M. and Johnson, P., "Recovery of Lactate Esters and Lactic Acid from Fermentation Broth”, US Patent 5210 296, June 20, 1990. Assignee: E. I. Du Pont de Nemours and Company.

3) Tung, L.A., and King, C.J., "Sorption and Extraction of Lactic Acid and Succinic Acids at pH > pKa1. 1. Factors Governing Equilibria, 2. Regeneration and Process Considerations”, Industrial and Engineering Chemistry Research, Vol. 33, p. 3217-3229, 1994. 
4) Sarhaddar, S., Scheibl, A., Berghofer, E., Cramer, A., “Lactic Acid Extraction and Purification Process”, US Patent 5641 406, June 24, 1997. Assignee: Vogelbusch Gesellschaft m.b.H.

5) Filachione, E., Costello, E., "Lactic Esters by Reaction of Ammonium Lactate with Alcohols”, Industrial and Engineering Chemistry, Vol. 44, No. 9, p. 2189-2191, 1952.

6) Cockrem, M. and Charles, M., "Process for the Production of Organic Acids and Esters Thereof”, WO 00/64850, November 2, 2000. Assignee: A. E. Staley Manufacturing Co.

7) Miao, F., "Method and Apparatus for the Recovery and Purification of Organic Acids”, US Patent 5681 728, October 28, 1997. Assignee: Chronopol, Inc.

8) Baniel, A., et. al., US Patents 5510 526, 5780 678, 5892 109, 6087 532, 6187951 B1, 6 472559 B2.

9) Busche, R.M., "Recovering Chemical Products from Dilute Fermentation Broths”, Biotechnology and Bioengineering Symp. No. 13, p. 597-615, 1983

10) Busche, R.M., Shimshick, E.J., Yates, R.A., "Recovery of Acetic Acid from Dilute Acetate Solution”, Biotechnology and Bioengineering Symp. No. 12, p. 249-262, 1982

11) Partin, L., Heise, W., in Agreda, V., Zoeller, J., (editors), Acetic Acid and Its Derivatives, Marcel Dekker, New York, pp. 3-13, 1993.

12) Eggeman, T., Verser, D., "Recovery of Organic Acids from Fermentation Broths”, Applied Biochemistry and Biotechnology, in press.

13) Urbas, B., "Recovery of Acetic Acid from a Fermentation Broth”, US Patent 4405717 , September 20, 1983. Assignee: CPC International Inc.

14) Urbas, B., "Recovery of Organic Acids from a Fermentation Broth”, US Patent 4444 881, April 24, 1984. Assignee: CPC International Inc.

15) Ricker, N. L., Michaels, J. N., King, C.J., "Solvent Properties of Organic Bases for Extraction of Acetic Acid from Water”, Journal of Separation Process Technology, Vol. 1, No. 1, 1979.

16) Sorenson, J.M., Arlt, W., Liquid-Liquid Equilibrium Data Collection, DECHEMA, Frankfurt, 1980. 


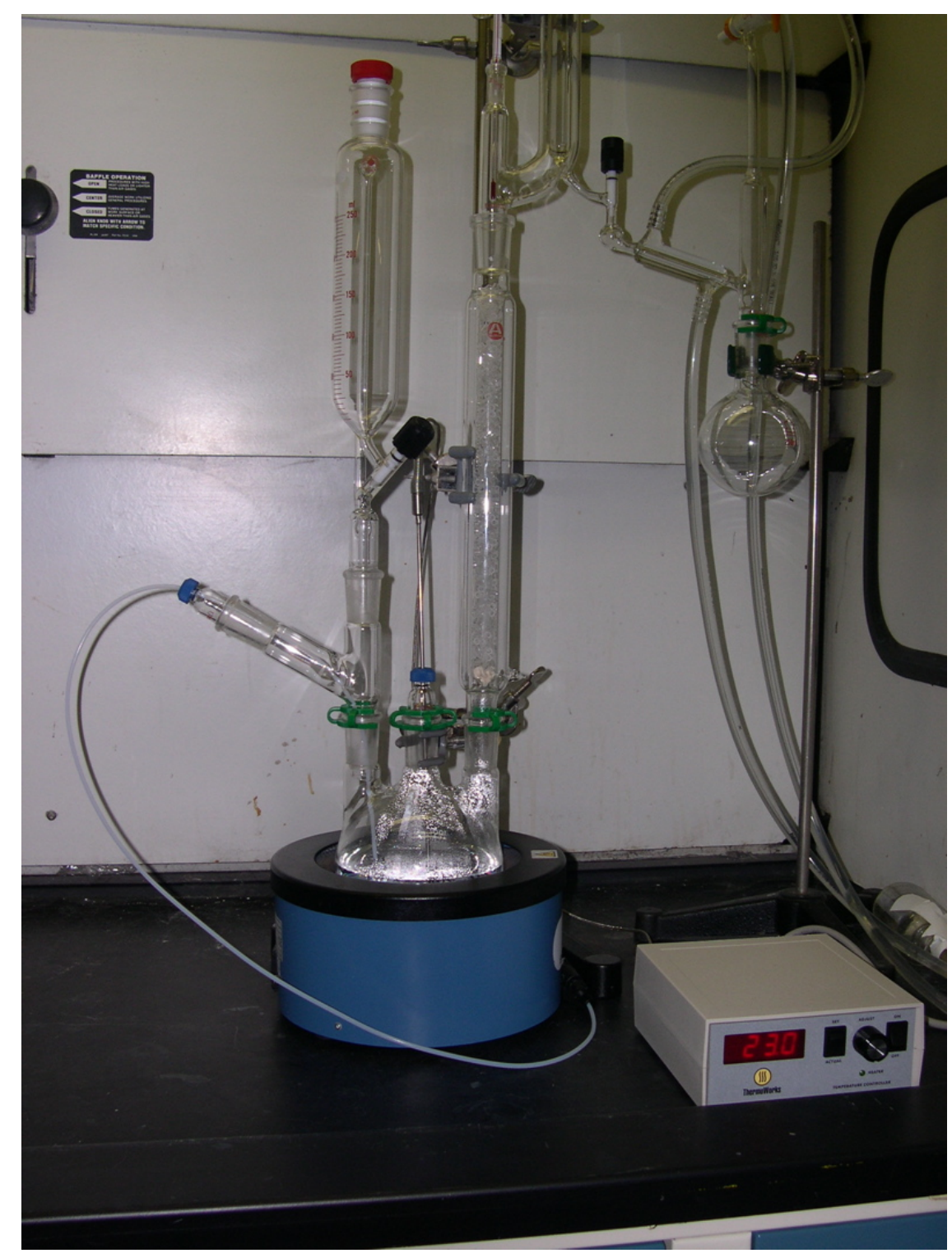

Figure 2.1 - Laboratory Apparatus for Esterification Experiments 
Organic Layer Mass Fractions

\begin{tabular}{|c|c|c|c|c|c|}
\hline \multicolumn{3}{|c|}{ Experimental } & \multicolumn{3}{|c|}{ HYSYS Gen NRTL } \\
\hline $\mathrm{H} 2 \mathrm{O}$ & $\mathrm{nC} 5 \mathrm{OH}$ & TBA:HAc & $\mathrm{H} 2 \mathrm{O}$ & $\mathrm{nC} 5 \mathrm{OH}$ & TBA:HAc \\
\hline 0.1074 & 0.8678 & 0.0248 & 0.1038 & 0.8710 & 0.0252 \\
\hline 0.1197 & 0.8051 & 0.0752 & 0.1168 & 0.8079 & 0.0753 \\
\hline 0.1353 & 0.7325 & 0.1322 & 0.1302 & 0.7387 & 0.1311 \\
\hline 0.1471 & 0.6806 & 0.1723 & 0.1405 & 0.6854 & 0.1741 \\
\hline
\end{tabular}

\begin{tabular}{|c|c|c|c|c|c|}
\hline \multicolumn{3}{|c|}{ Experimental } & \multicolumn{3}{|c|}{ HYSYS Gen NRTL } \\
\hline $\mathrm{H} 2 \mathrm{O}$ & $\mathrm{nC} 5 \mathrm{OH}$ & TBA:HAC & $\mathrm{H} 2 \mathrm{O}$ & $\mathrm{nC5OH}$ & TBA:HAC \\
\hline 0.9540 & 0.0185 & 0.0275 & 0.9550 & 0.0178 & 0.0272 \\
\hline 0.9166 & 0.0190 & 0.0645 & 0.9157 & 0.0199 & 0.0644 \\
\hline 0.8779 & 0.0195 & 0.1027 & 0.8736 & 0.0223 & 0.1040 \\
\hline 0.8399 & 0.0200 & 0.1401 & 0.8364 & 0.0248 & 0.1388 \\
\hline
\end{tabular}

Experimental Tie Lines

TBA:HAc

$-\ominus-$ HYSYS Tie Lines

HYSYS Two Phase Boundary

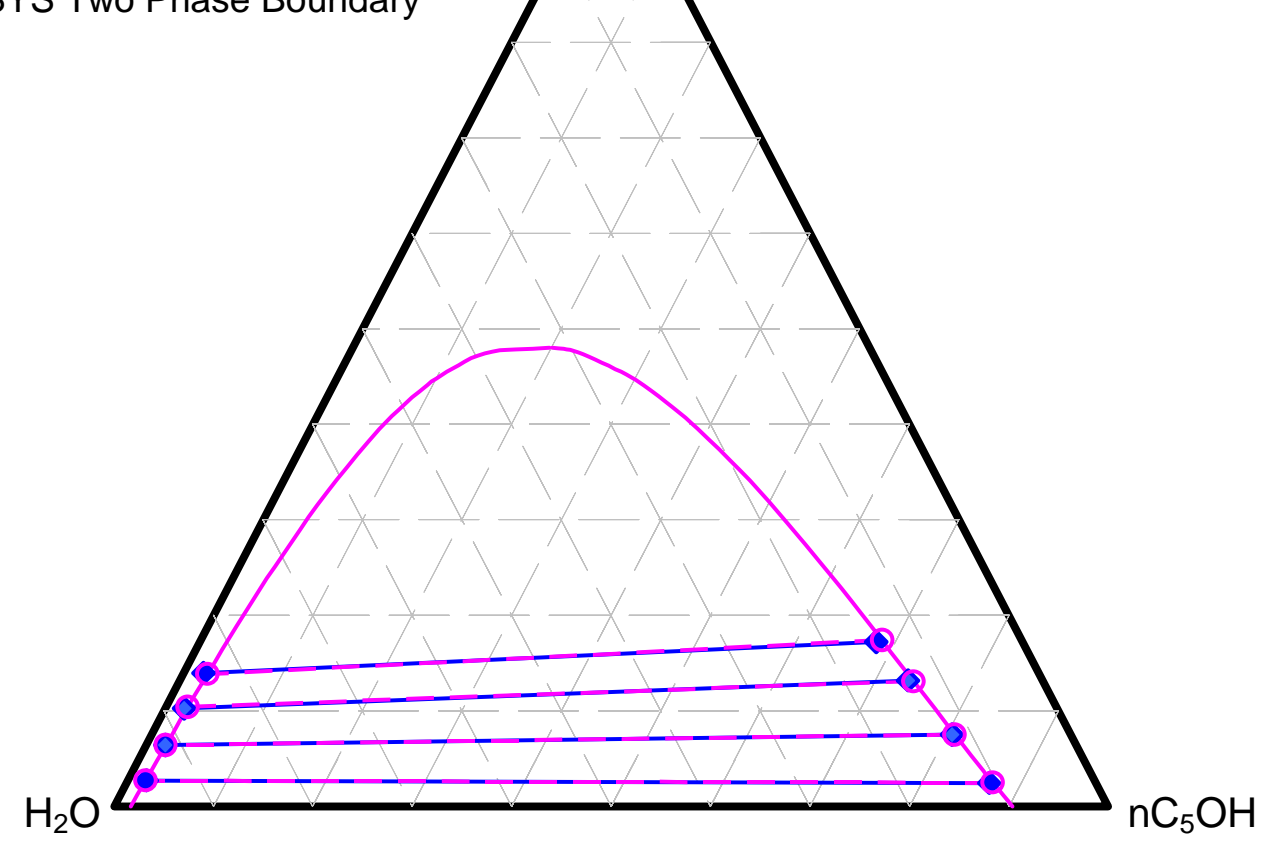

$\left(25^{\circ} \mathrm{C}\right.$, Mass Fraction Basis)

Figure 2.2 - Phase Diagram for the Water + TBA:HAc + n-Pentanol System 


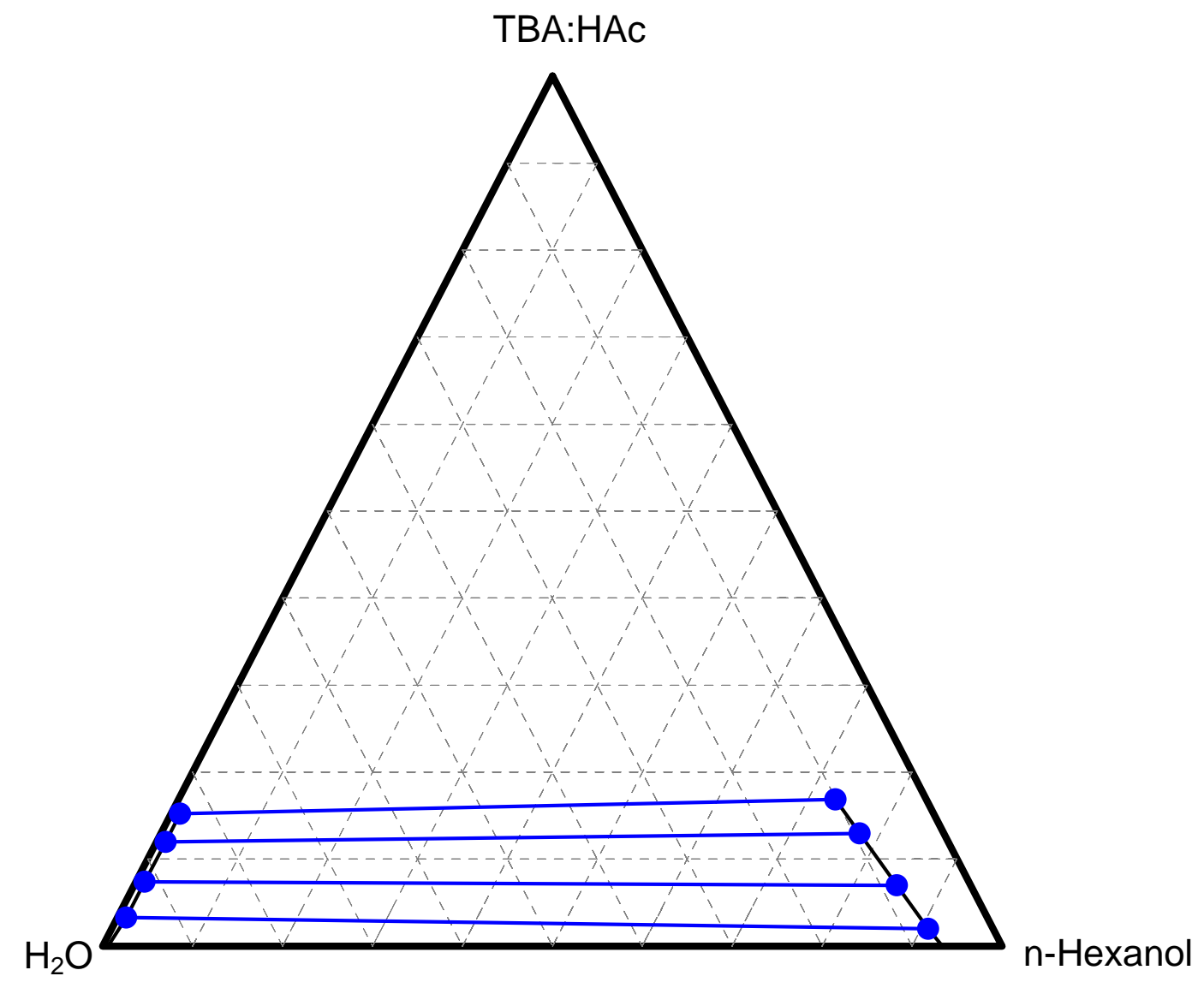

$\left(25^{\circ} \mathrm{C}\right.$, Mass Fraction Basis)

Figure 2.3 - Experimental Phase Diagram for the Water + TBA:HAc + n-Hexanol System 
Figure 2.4 - Comparison of Esterification Experimental Results

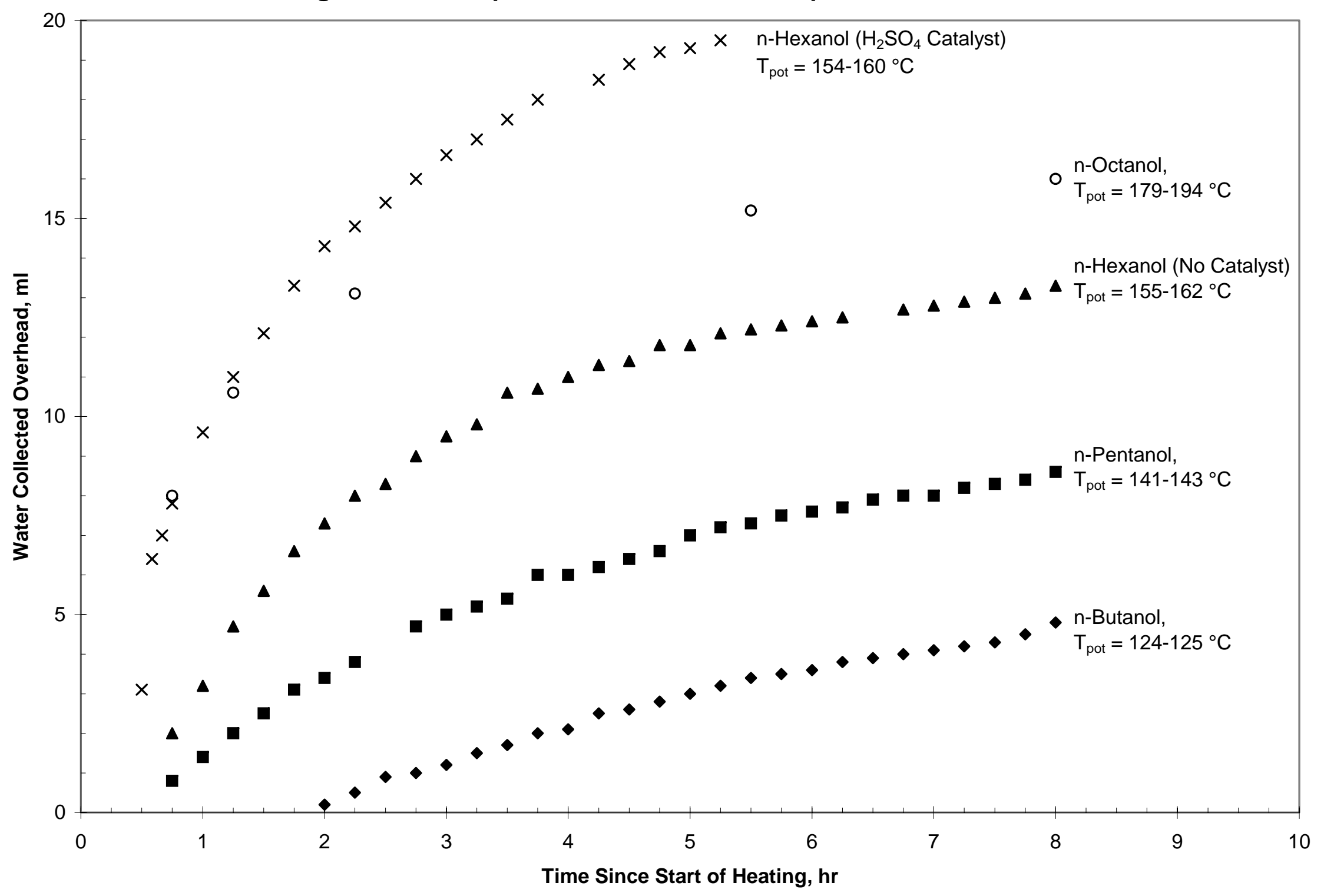




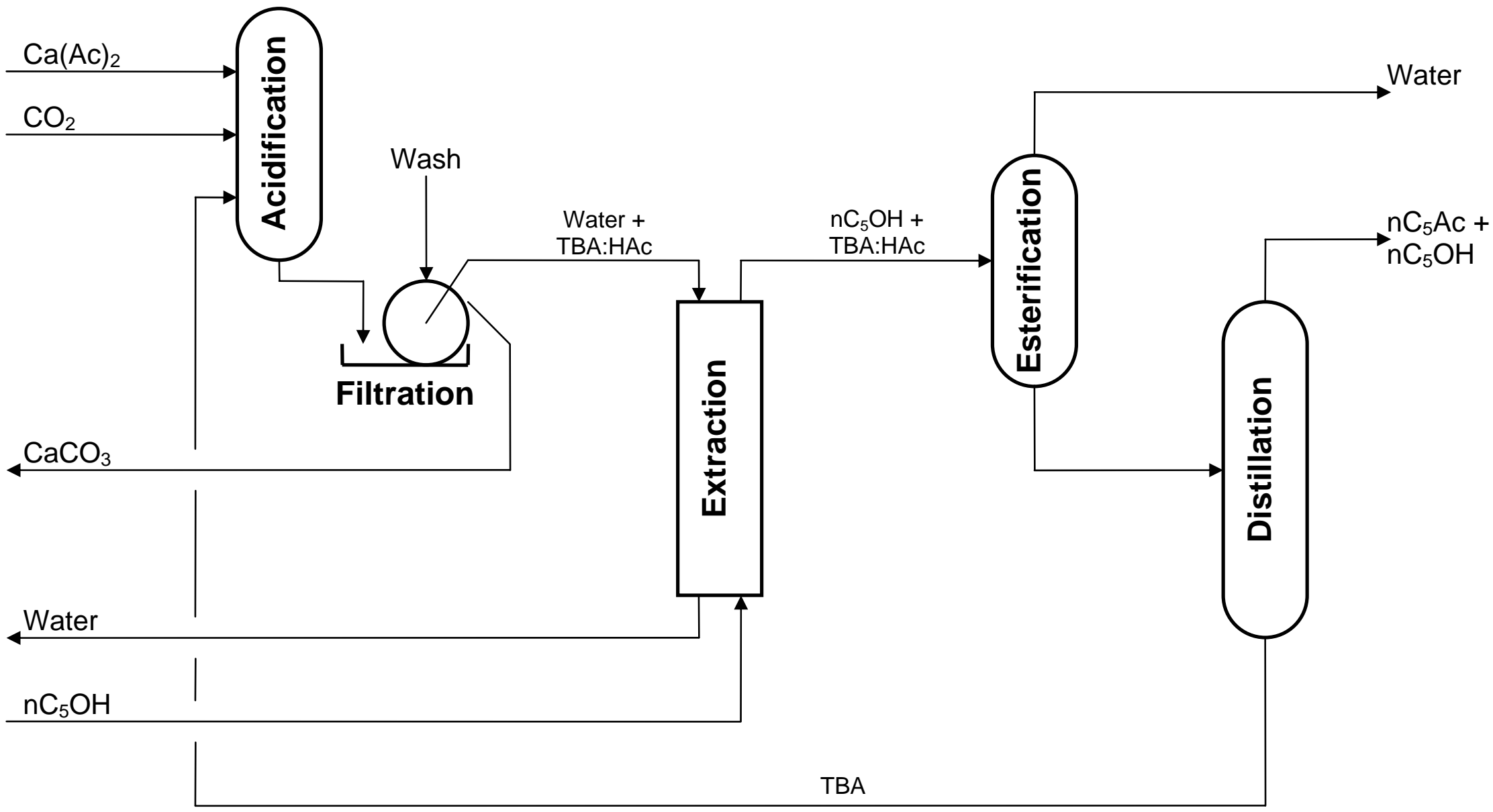

Figure 2.5 - Simplified Sketch of Recovery Process Using n-Pentanol as the Esterifying Alcohol 
Table 2.1 - Extraction Solvent Screening Results For the TBA:HAc Complex

$\begin{array}{ccc}\text { Solvent } & \text { Delectivity } \\ \text { Ethyl Acetate } & 0.105 & \\ \text { Butyl Acetate } & 0.082 & \\ \text { Toluene } & 0.0392 & \\ \text { 2-Octanone } & 0.087 & \\ \text { Chloroform } & 0.987 & \\ \text { Ethyl Acetate/Ethanol (2/1) } & 0.293 & \\ \text { Ethyl Propionate/Ethanol (1/1) } & 0.249 & \\ \text { n-Butanol } & 2.40 & 14.79 \\ \text { n-Pentanol } & 1.45 & 19.26 \\ \text { n-Hexanol } & 1.13 & 21.91 \\ \text { n-Octanol } & 0.75 & \end{array}$


Table 2.2 Comparison of Alcohols in the Extraction Solvent Screening and Esterification Experiments

$\begin{array}{lccc}\text { Solvent } & \text { Distribution Coefficient } & \text { Selectivity } & \begin{array}{r}\text { Esterification } \\ \text { Yield at } 4 \mathrm{hr}, \\ \text { \% Theoretical }\end{array} \\ \text { n-Butanol } & 2.40 & 8.79 & 12.6 \\ \text { n-Pentanol } & 1.45 & 14.77 & 38.1 \\ \text { n-Hexanol } & 1.13 & 19.26 & \begin{array}{c}82.7 / 93.6 \\ \text { n-Octanol }\end{array} \\ & 0.75 & & \text { (No Catalyst / } \mathrm{H}_{2} \mathrm{SO}_{4} \text { Catalyst) } \\ 88.8\end{array}$




\section{Task 3 - Modeling}

\section{Process Model}

The design basis for the model is a grassroots facility that produces $100 \mathrm{MMgal} / \mathrm{yr}$ (denatured) ethanol using the indirect process route. Carbohydrate and nutrients are supplied to the plant by an across-the-fence corn wet mill. HYSYS v3.2 (Build 5029), a commercial process simulator licensed from Aspen Technologies Inc., was use to perform the detailed material and energy balance calculations for the process model. Process performance assumptions are based on P90 assumptions for critical process parameters (i.e. the assumptions do not represent observed laboratory performance, but are in-line with what should be achievable with a modest amount of R\&D effort. In this case, the estimated probability for success of the required R\&D program is 90\%). The design and economics are based upon nth plant assumptions.

Figure 3.1 is a simplified block flow diagram for the base case. A portion of the starch hydrolyzate and light steep water streams from an existing corn wet mill are used as carbohydrate and nutrient sources for the fermentation step. The acetate is recovered from the broth and an acetate ester is produced by esterification with the recycle alcohol. This ester then undergoes hydrogenolysis to produce the desired ethanol product plus the recycle alcohol. Hydrogen is provided by gasification of corn stover. A portion of the syngas produced by the gasifier is diverted to the combined cycle unit. The combined cycle unit produces steam and power using a gas turbine topping cycle and a non-condensing steam turbine bottoming cycle.

The corn wet mill was not explicitly modeled. Starch hydrolyzate, light steep water, and steep water return streams are transferred to/from the ethanol plant at a negotiated transfer price. Utility and infrastructure systems for steam, power, cooling water, raw material storage and final product storage were explicitly modeled in the simulations. Other utility and infrastructure systems were accounted in the economics by appropriate allocations for capital and operating costs. Appendix E contains a detailed process description. Major design assumptions, as well as detailed process flow diagrams with material and energy balance information, are presented in this appendix.

Several variations on the base process model were considered. The Balanced Case, summarized in Figure 3.2, assumes the combined cycle block is replaced with a simple boiler+non-condensing steam turbine to provide steam and power for the plant. The Minimum Capital Case, summarized in Figure 3.3, assumes that hydrogen is purchased at $\$ 2.50$ per 1000 SCF and eliminates the gasification section of the plant. The Defined Media Case, summarized in Figure 3.4, improves integration with the wet mill by replacing the light steep water medium with a defined media; the cell mass and residual fermentables are no longer returned to the mill but are digested to produce a methane rich biogas used as a fuel trim for the gasifier.

\section{Economic Model}

An economic model was assembled using the process model as the basis. The economic analysis consists of a factored capital cost estimate, an operating cost estimate, a revenue summary, discounted cash flow calculations, plus single parameter and Monte Carlo sensitivity 
analyses for each case. Appendix F provides a detailed discussion of the economic model for the Base Case.

Table 3.1 summarizes the economic analyses. The Base Case is projected to have a fixed capital cost of $\$ 2.97$ per annual gallon of capacity. A typical corn dry mill of equivalent capacity would require \$1.00-1.50 of fixed capital per annual capacity based on our survey of recent plant announcements in (1). Projected fixed capital requirements for direct fermentation ethanol plants using lignocellulosic feedstocks are much higher, for example, the goal case considered in (2) estimates fixed capital at \$2.85 per annual gallon of capacity. The projected capital costs for the Base Case appear to be reasonable given that both a conventional feedstock (e.g. starch hydrolyzate) and a lignocellulosic feed (e.g. corn stover) are handled in the facility.

Operating costs are projected to be $\$ 1.58$ per gal (denatured) without credits for electricity or steep water return sales. Cash costs are $\$ 1.28$ per gal (denatured) on the same basis. Revenues from electricity sales and steep water return sales are \$0.44 per gal (denatured), so net cash costs are $\$ 0.84$ per gal (denatured). Our internal estimate of the net cash cost for a comparable size corn dry mill are $\$ 0.99$ per gal (denatured), so the indirect route appears to have a net cash cost advantage over conventional dry mill technology.

Discounted cash flow calculations use the time value of money concept to combine capital costs, operating costs, and revenues into one or more performance measures. The calculations can be done on either a rational pricing or market pricing basis, the choice of which depends on the objectives of the analysis. The rational ethanol price, defined as the ethanol price required for an internal rate of return (IRR) of $10 \%$ nominal after-tax for the project, is typically used in research environments to compare emerging technologies without complications caused by the consideration of market forces. The market price of ethanol depends upon many factors. A primary factor is its value in use, which in turn, is strongly influenced by the price of crude oil. In Appendix F we discuss historical rack prices for denatured fuel grade ethanol, Midwest basis, over the time period 1990-2004. Based on this preliminary market analysis, we selected a market ethanol price of \$1.24 per gal (denatured) for the internal rate of return calculations reported in Table 3.1. At the time of this writing, crude oil prices are at historic nominal highs, current ethanol prices are much higher than $\$ 1.24$, so the reported internal rates of return are much lower than those that would result from using current market conditions.

The Base Case is projected to have a rational ethanol price of \$1.29 per gal (denatured) or an IRR of $8.7 \%$ (nominal, after-tax). Thus, while the indirect route has a cash cost advantage over conventional dry mill technology, the higher capital cost of the indirect route results in comparable discounted cash flow measures between the Base Case and conventional dry mill technology.

Single parameter and Monte Carlo sensitivity analyses of the Base Case economic models were done to find the drivers of economic performance and refine the focus of future R\&D efforts. The price of starch hydrolyzate was found to be a major driver of the economics. In actual practice, the price of starch hydrolyzate would be set by contractual agreement with the host corn wet mill. This agreement would most likely transfer commodity risk from the wet mill to the ethanol facility via a formula that takes into account fluctuations in corn and related wet 
mill co-product prices. The formula would also include a fixed margin to account for other processing costs and provide a financial return to the mill.

The Base Case model assumed starch hydrolyzate would be purchased from the mill at $\$ 0.05$ per lb (dry). As shown in Appendix F, this roughly corresponds to a corn price of $\$ 2.50$ per bushel. At the time of this writing, corn prices are on the order of $\$ 2.00$ per bushel. Using this lower corn price, the IRR for the project is projected to be on the order of $15 \%$ (nominal, after-tax). Thus, the economic performance is quite sensitive to the price of fermentable carbohydrate.

The Balanced Case presented in Figure 3.2 and Table 3.1 replaces the gas turbine cogeneration system with a simple boiler+non-condensing steam turbine. The amount of corn stover fed to the gasifier is reduced since the design is required to be in steam balance and is very close to being in power balance. Capital costs, operating costs, and revenues are all reduced compared to the Base Case. As shown by the discounted cash flow performance measures, the reduction in revenue more than offsets the reduction in capital and operating costs, resulting in poorer economic performance.

The Minimum Capital Case presented in Figure 3.3 and Table 3.1 assumes that hydrogen can be purchased from a pipeline at $\$ 2.50$ per SCF. Pipeline hydrogen prices are often based on a formula that takes into account the price of natural gas (i.e. the primary feedstock used for hydrogen production via steam methane reforming). A hydrogen price of \$2.50 per SCF would roughly correspond to a natural gas price in the range of \$4.00-5.00 per MMBtu. As shown in Table 3.1, the reduction in capital cost for the Minimum Capital Case is offset by higher operating costs and lower revenues, resulting in poorer economic performance when compared to the Base Case.

The Defined Medium Case presented in Figure 3.4 and Table 3.1 replaces the light steep water nutrient source with a defined medium. The residual solubles and cell mass produced in the fermentation are digested to produce a methane rich biogas that is used as a fuel trim for the gasifier. When compared to the Base Case, the Defined Medium Case has slightly higher capital costs, comparable operating costs, and lower revenues. The lower revenues are a result of the fact that there is no longer a steep water return stream. Although this case does show poorer economic performance when compared to the Base Case, integration with the mill would be easier and performance of the fermentation recovery system would probably be better since the broth would be cleaner.

As discussed earlier, the sensitivity analysis showed that the cost of the fermentable carbohydrate strongly influences the projected economic performance. While starch hydrolyzate does have the advantage of being a relatively clean source of carbohydrate, it is relatively expensive. The acetogens used in our indirect process are capable of processing a mixed sugar stream such as those commonly encountered with biomass hydrolyzates. The gasifier and much of the other infrastructure needed to handle a biomass feedstock are already present in the Base Case. Converting the Base Case to a biomass feed would only require the addition of a pretreatment step, an enzymatic hydrolysis step, and some solids separation/dewatering equipment to prepare the solid residuals from fermentation for gasification. As mentioned in the 
Project Description section of this report, a biomass feedstock is efficiently handled by the indirect process since all of the chemical energy stored in the feedstock is potentially available for conversion into ethanol.

Rigorous modeling of a biomass feedstock is outside the scope of work for this grant. However, we have included a block flow diagram in Figure 3.5 and some order-of-magnitude economic projections in Table 3.1. We expect that a rational ethanol price on the order of \$1.001.10 per gal (denatured) could be attained given the recent improvements in pretreatment technology and recent breakthroughs in lowering prices for cellulase and hemicellulase enzymes. Future R\&D efforts for the indirect process should focus on processing of biomass hydrolyzates.

\section{Energy Savings Metrics}

One purpose of detailed process modeling is to formulate quantitative answers to policy level questions such as the energy savings metrics considered in this grant. However, great care must be taken to define the system to ensure that results of these calculations are meaningful. Fortunately, USDA has spent quite a bit of effort in analyzing the net energy value of corn derived ethanol. For the conventional technology case of Table 3.2, we repeat the results given in (3) which report energy usage per gallon (neat) of ethanol produced on a higher heating value basis. Their analysis includes energy usage for corn production including the energy content of fertilizers, corn transportation, ethanol conversion, and ethanol distribution. Their value for ethanol conversion is an industry weighted average of energy usage for both wet mill and dry mill technologies. Co-product credits are estimated using the replacement value method. Under their assumptions, the energy ratio (defined as the ratio of the green energy produced divided by the fossil energy consumed) for the convention technology case is 1.34.

The second column of values in Table 3.2 shows a breakdown of energy usage for the Base Case assuming the wet mill utilities are provided by fossil energy resources, which is widely practiced in the industry today. Values for corn production and transportation were directly ratioed from the USDA model. Values for stover production and transport were taken from a recent life cycle analysis from the National Renewable Energy Laboratory (4). The ethanol conversion entry refers to the fossil energy consumed in the front end corn wet mill. The back-end ethanol plant in the Base Case derives its steam and power from corn stover, so these are not counted in the ethanol conversion entry for this analysis. In fact, a credit is taken later since the ethanol plant is a net exporter of green electricity. Ethanol distribution and feed coproduct credits from the wet mill are ratioed directly from the USDA model. The resulting energy ratio for the Base Case is 3.11, much higher than the energy ratio of 1.34 for the conventional technology case.

The third column of values in Table 3.2 shows a breakdown of energy usage for the Base Case assuming the wet mill utilities are provided by green resources. The resulting energy ratio is 5.73, showing that the source of the energy used to process the feedstock into a fermentable substrate can have a dramatic impact on the environmental performance of the overall process. Green utilities could be provided to the wet mill by expanding the gasifier/cogeneration section of the ethanol plant or by other means such as combustion of landfill gas in the existing wet mill boilers. 
We expect that the environmental performance for the Biomass Feed Case considered previously in Figure 3.5 would also be much better than the Base Case. The fossil energy input required for growing most lignocellulosic feedstocks is much less than that required for corn. This, plus the fact that all of the utilities in the Biomass Feed case are derived from renewables, suggests that very high energy ratios could result. The last column of values in Table 3.2 were derived from the data in (5) for fossil inputs required for lignocellulosic crops and an assumed chemical energy efficiency in ethanol conversion of 65\% with the balance of feedstock energy used for utility production with no export/import of steam or power. An energy ratio of 12.32 is projected. Further improvements in energy ratio would result if the restriction on export power is relaxed. These findings strengthen the previous recommendation for future R\&D efforts in processing biomass hydrolyzates with the indirect process.

The forecast for 2010 assumes the indirect process is responsible for $100 \mathrm{MMgal} / \mathrm{yr}$ (neat) of ethanol production. This is a small percentage of market projections, which typically predict 2010 ethanol production at about 5 billion gallons/yr. The projected energy savings for adopting the indirect route is 7.48 trillion Btu/yr if the wet mill front-end derives its utilities from fossil resources, or 9.56 trillion Btu/yr if the wet mill front-end derives its utilities from green resources. Slightly lower energy savings is projected for the Biomass Feed case (5.60 trillion $\mathrm{Btu} / \mathrm{yr}$ ) since this case assumes no credit for power export.

\section{Sub-Task Review}

The description of the sub-tasks, taken from Appendix B Statement of Work in the original proposal, is repeated below:

Task 3.1 Process Modeling - An integrated process model of the fermentation and esterification steps will be created and used to guide the experimental program. Rigorous material and energy balances will be generated using HYSYS.Process, a commercial process simulation package currently licensed by ZeaChem. The kinetic models developed in the experimental program will be used to generate several reactor designs that are potentially suitable for use at the semi-works facility. All auxiliary processing steps, such as broth clarification prior to esterification, will also be rigorously modeled. The outcome of this task will be a high quality process model that can be used to support the design of a semi-works commercial facility.

Task 3.2 Economic Modeling - The process models developed in Task 3.1 will be used as the basis for economic evaluation. Discounted cash flow calculations will be done in Excel and will be used as the basis for evaluation of process alternatives. Capital and operating costs will be estimated using standard factored estimation methods. The outcome of this task will be a high quality economic model that can be used to guide the experimental program and support our future commercialization efforts.

The following discussion compares the work actually accomplished against the original proposal subtasks:

Task 3.1 Process Modeling - Complete. 
Task 3.2 Economic Modeling - Complete.

\section{References}

1) Ethanol Producer Magazine, BBI International, www.ethanolproducer.com

2) Aden, A., Ruth, M., Ibsen, K., Jechura, J., Neeves, K., Sheehan, J., Wallace, B., Montague, L., Slayton, A., Lukas, J., "Lignocellulosic Biomass to Ethanol Process Design and Economics Utilizing Co-Current Dilute Acid Prehydrolysis and Enzymatic Hydrolysis for Corn Stover", National Renewable Energy Laboratory, NREL/TP-510-32438, June, 2002.

3) Shapouri, H., Duffield, J.A., Wang, M., "The Energy Balance of Corn Ethanol: An Update”, United States Department of Agriculture, Agricultural Economic Report Number 814, July, 2002. See: www.usda.gov/oce/oepnu/aer-814.pdf

4) Sheehan, J., Aden, A., Riley, C., Paustian, K., Killian, K., Brenner, J., Lightle, D., Nelson, R., Walsh, M., Cushman, J., "Is Ethanol From Corn Stover Sustainable? Adventures in CyberFarming: A Life Cycle Assessment of the Production of Ethanol from Corn Stover for Use in a Flexible Fuel Vehicle”, Draft Report, December, 2002.

5) Lynd, L., Wang, M., “A Product-Nonspecific Framework for Evaluating the Potential of Biomass-Based Products to Displace Fossil Fuels”, Journal of Industrial Ecology, Vol. 7, No. 34, p. 17-32, 2004. 


\section{Figure 3.1 - Base Case Block Flow Diagram}

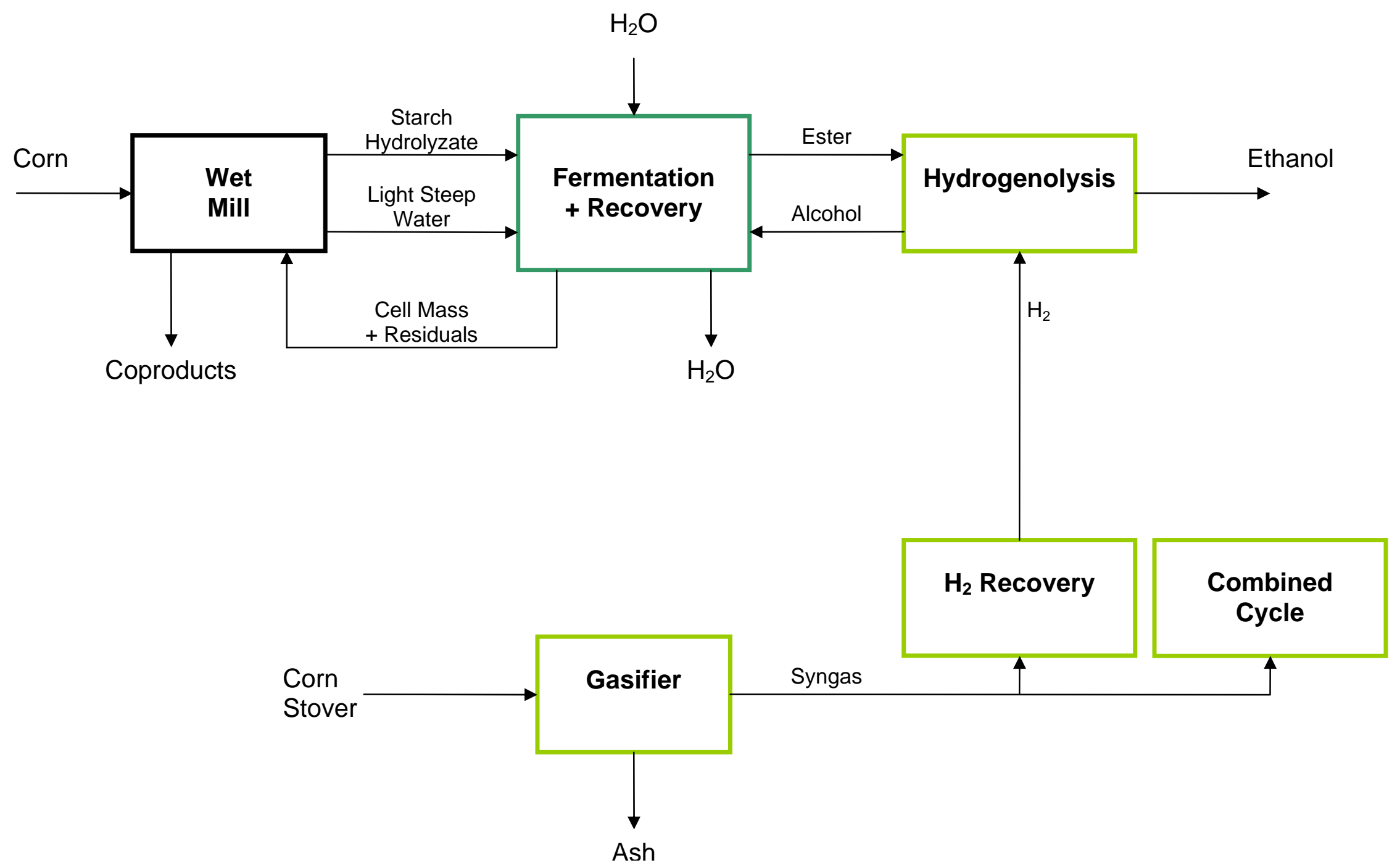




\section{Figure 3.2 - Block Flow Diagram for Balanced Case}

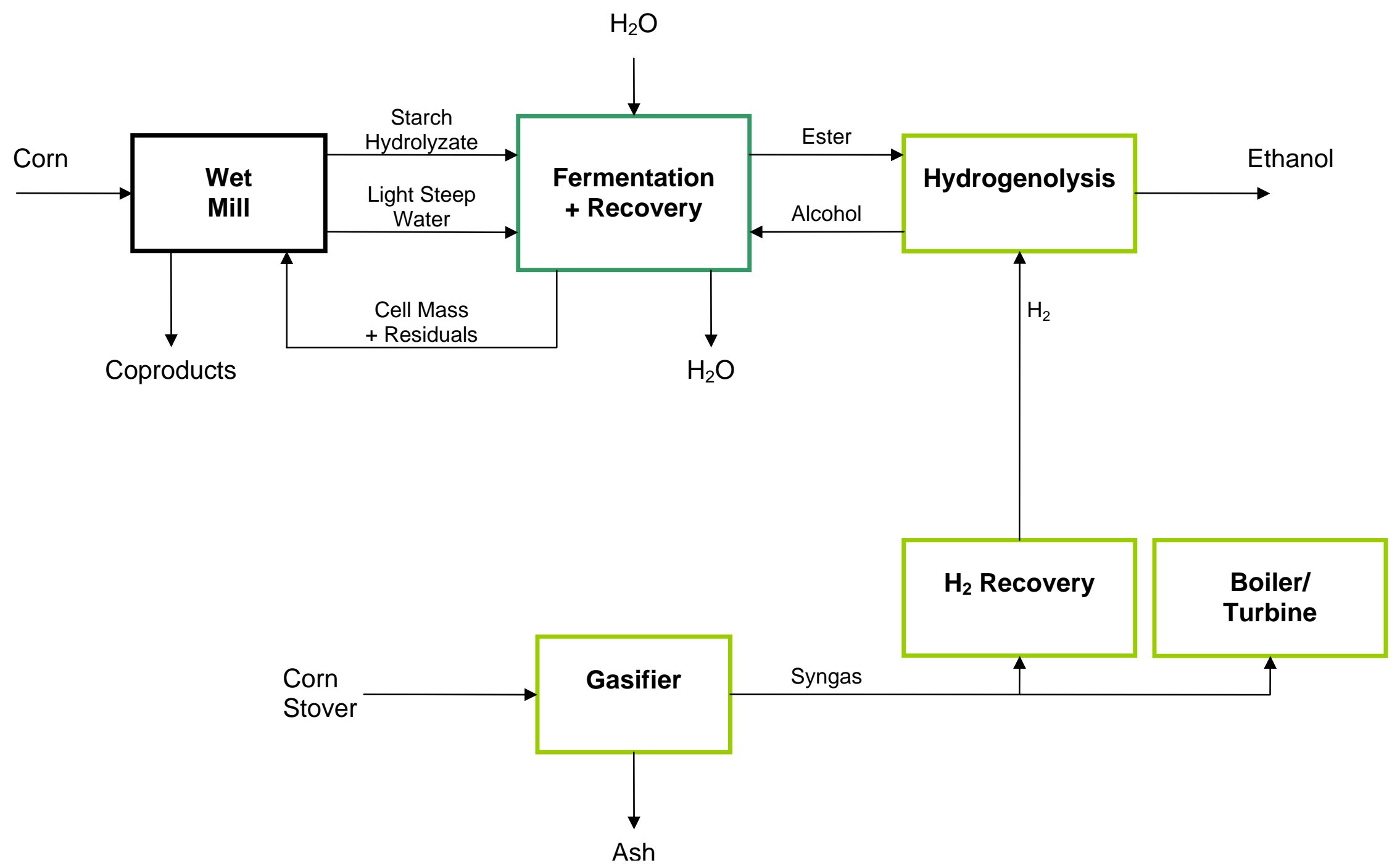




\section{Figure 3.3 - Block Flow Diagram for Minimum Capital Case}

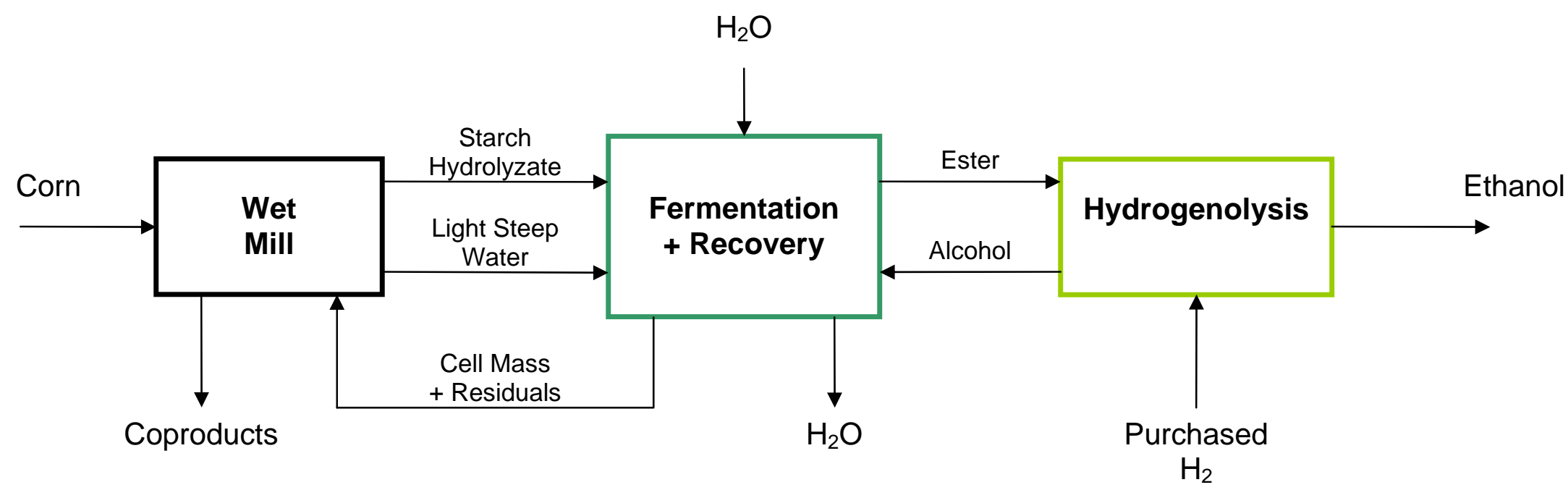


Figure 3.4 - Block Flow Diagram for Defined Medium Case

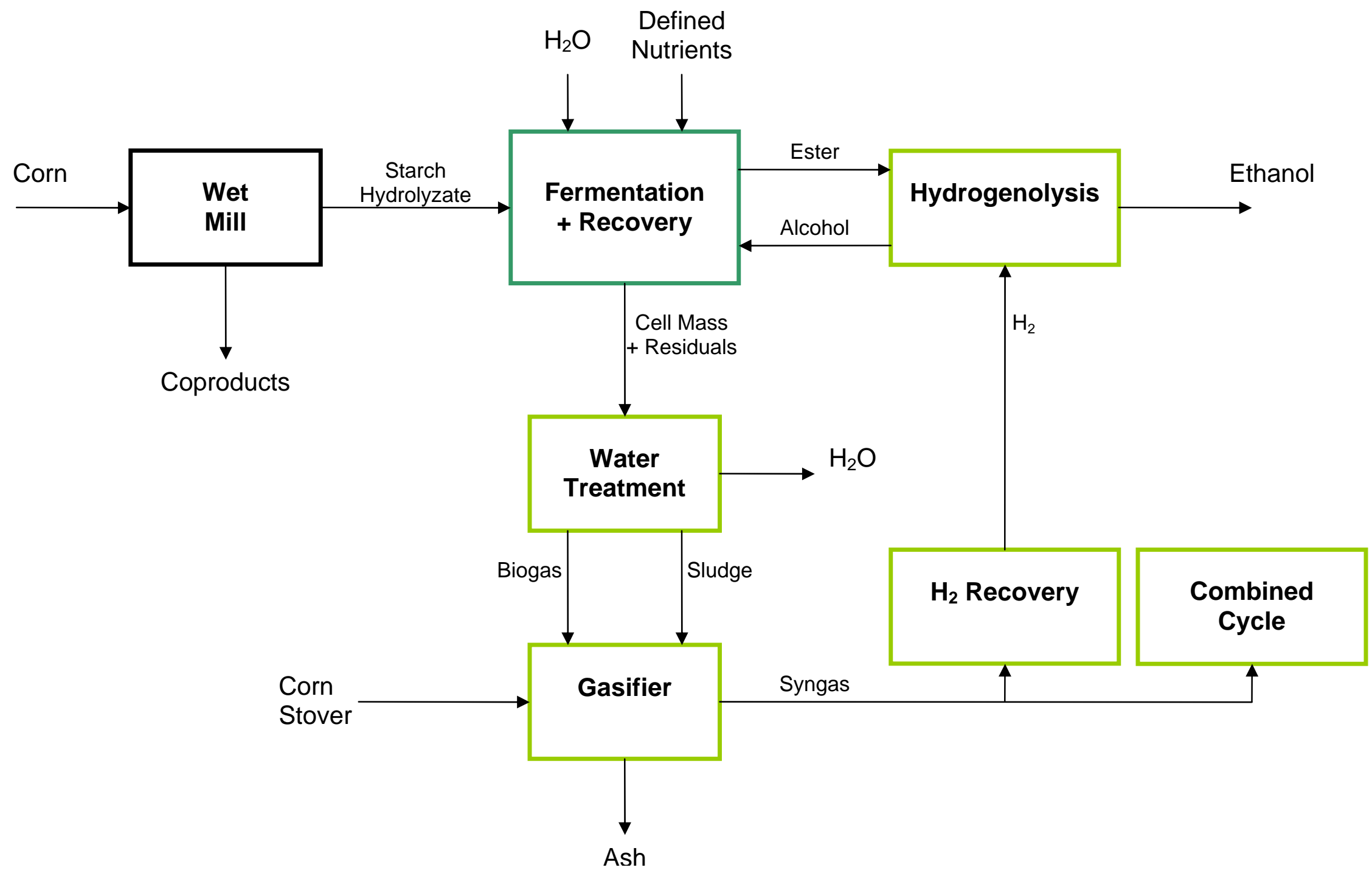




\section{Figure 3.5 - Block Flow Diagram for Biomass Feed Case}

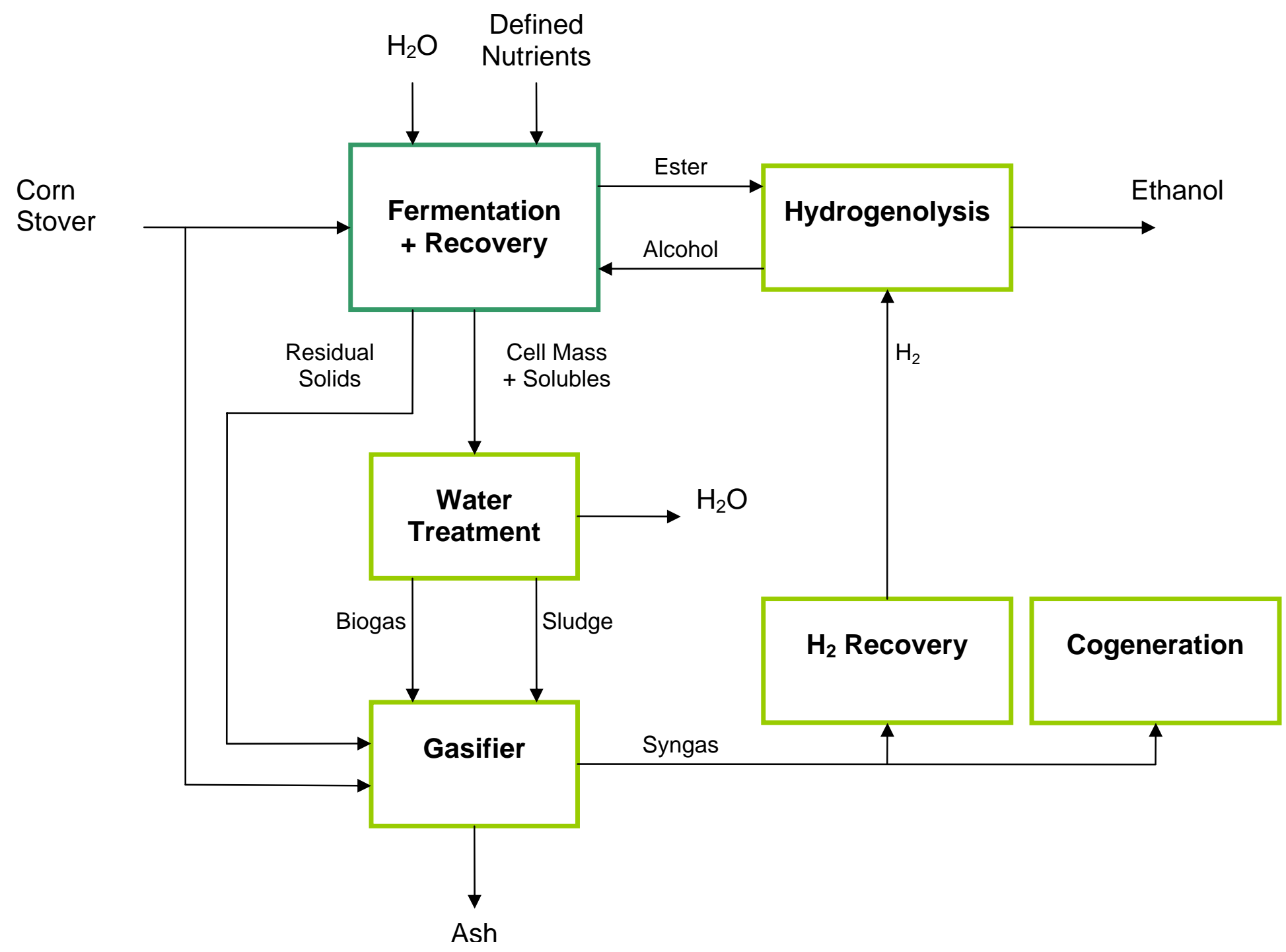


Table 3.1 Economic Summary

100 MM Gal/yr (Denatured) EtOH Facility

\begin{tabular}{|c|c|c|c|c|}
\hline Base & Balanced & $\begin{array}{c}\text { Minimum } \\
\text { Capital } \\
\end{array}$ & $\begin{array}{l}\text { Defined } \\
\text { Medium } \\
\end{array}$ & $\begin{array}{c}\text { Biomass } \\
\text { Feed }^{*}\end{array}$ \\
\hline 297.3 & 248.7 & 138.2 & 307.3 & 356.6 \\
\hline 34.6 & 29.3 & 23.5 & 33.5 & 33.3 \\
\hline$\overline{331.9}$ & $\overline{278.0}$ & 161.7 & 340.8 & 389.9 \\
\hline 1.07 & 0.98 & 1.24 & 1.06 & 0.83 \\
\hline 0.51 & 0.43 & 0.24 & 0.52 & 0.61 \\
\hline 1.58 & 1.41 & 1.48 & 1.58 & 1.44 \\
\hline 1.28 & 1.16 & 1.34 & 1.28 & 1.08 \\
\hline 167.6 & 143.4 & 141.6 & 154.5 & 208.2 \\
\hline
\end{tabular}

\section{Profitability}

$$
\text { Rational EtOH Price, }
$$

$\$ / g a l$ (Denatured)

IRR, Nominal After-Tax

1.29

1.35

$6.8 \%$

1.41

$-0.3 \%$

1.44

1.06

$8.7 \%$

$5.0 \%$

* Order-of-Magnitude Results. Biomass Feed Case was not modeled to the same level of detail as the other cases. 


\section{Table 3.2 Summary of Energy Metrics}

\begin{tabular}{|c|c|c|c|c|}
\hline nergy Metrics per Gallon of Ethanol & $\begin{array}{c}\text { Conventional } \\
\text { Technology, } \\
\text { Btu (HHV) / } \\
\text { gal EtOH (neat) } \\
\end{array}$ & $\begin{array}{c}\text { ZeaChem } \\
\text { Base Case, } \\
\text { Btu (HHV) / } \\
\text { gal EtOH (neat) } \\
\end{array}$ & $\begin{array}{c}\text { ZeaChem } \\
\text { Base Case w/ } \\
\text { Green Wet Mill, } \\
\text { Btu (HHV) / } \\
\text { gal EtOH (neat) }\end{array}$ & $\begin{array}{c}\text { ZeaChem w/ } \\
\text { Biomass Feed, } \\
\text { Btu (HHV) / } \\
\text { gal EtOH (neat) } \\
\end{array}$ \\
\hline \multicolumn{5}{|l|}{ Fossil Energy Use } \\
\hline Crop Production & 21,598 & 15,566 & 15,566 & 2,339 \\
\hline Crop Transport & 2,263 & 1,631 & 1,631 & 2,886 \\
\hline Stover Production \& Transport & 0 & 16,573 & 16,573 & 0 \\
\hline Ethanol Conversion & 51,779 & 20,833 & 0 & 0 \\
\hline Ethanol Distribution & 1,588 & 1,588 & 1,588 & 1,588 \\
\hline Subtotal & 77,228 & 56,192 & 35,359 & 6,813 \\
\hline \multicolumn{5}{|l|}{ Coproduct Credits } \\
\hline Mill Coproducts & 14,372 & 10,670 & 10,670 & 0 \\
\hline \multirow{2}{*}{ Net Electricity Export (Thermal Equivalent) } & 0 & 57,425 & 57,425 & 0 \\
\hline & 14,372 & 68,095 & 68,095 & 0 \\
\hline Fossil Energy w/ Coproduct Credits & 62,856 & $-11,903$ & $-32,736$ & 6,813 \\
\hline Ethanol Higher Heating Value & 83,961 & 83,961 & 83,961 & 83,961 \\
\hline Net Green Energy & 21,105 & $\overline{95,864}$ & 116,697 & 77,148 \\
\hline Energy Savings vs. Conventional Technology & - & 74,759 & 95,592 & 56,043 \\
\hline Energy Ratio & 1.34 & 3.11 & 5.73 & 12.32 \\
\hline nergy Metrics Forecast for 2010 & $\begin{array}{l}\text { Conventional } \\
\text { Technology }\end{array}$ & $\begin{array}{l}\text { ZeaChem } \\
\text { Technology }\end{array}$ & $\begin{array}{l}\text { ZeaChem } \\
\text { Technology }\end{array}$ & $\begin{array}{l}\text { ZeaChem } \\
\text { Technology }\end{array}$ \\
\hline Estimated Capacity in US by 2010, MMgal EtOH/yr (neat) & 5,000 & 100 & 100 & 100 \\
\hline Estimated Fossil Energy Savings by 2010 , Trillion Btu/yr & - & 7.48 & 9.56 & 5.60 \\
\hline
\end{tabular}




\section{Task 4 - Reporting}

\section{Sub-Task Review}

The description of the sub-tasks, taken from Appendix B Statement of Work in the original proposal, is repeated below:

Task 4.1 Progress Reports - Two semi-annual progress reports will be submitted to DOE.

Task 4.2 Final Report - One final report will be submitted to DOE within 3 months of completion of the experimental portion of the work. At the discretion of ZeaChem Inc., this report could be used as a basis for future technical presentations and publications. The Annual Symposium on Biotechnology for Fuels and Chemicals meeting in May 2004, The American Institute of Chemical Engineers (AIChE) annual national meeting in November 2004, and the Corn Utilization Conference sponsored by the National Corn Growers Association are potential presentation forums.

The following discussion compares the work actually accomplished against the original proposal subtasks:

Task 4.1 Progress Reports - The reporting frequency was changed by US DOE from semiannual in the Solicitation to quarterly in the final contract. Eight quarterly reports were submitted on-time per the revised reporting requirements.

Task 4.2 Final Report - This document constitutes the final technical report and was submitted prior to the June 2005 deadline given in the final contract.

Two oral presentations on portions of this work were given in public forums:

1) "Recovery of Organic Acids From Fermentation Broths". Southern Bio-Products Conference, Beau Rivage Resort, Biloxi, MS, March 4-6, 2004

2) "Recovery of Organic Acids From Fermentation Broths”, Oral Presentation 3-05, 26th Symposium on Biotechnology for Fuels and Chemicals, Chattanooga, TN, May 11, 2004

One paper based on a portion of this work was authored, peer reviewed and submitted for publication in Applied Biochemistry and Biotechnology. Final publication of this paper, entitled "Recovery of Organic Acids from Fermentation Broths", is scheduled for Spring 2005.

One provisional patent application, based on a portion of this work, was submitted to the US Patent and Trademark Office. US DOE has certain rights to this intellectual property as specified in the contract for this grant. US DOE was notified of our filing; US DOE responded with an acknowledgement letter and provided a case number for future correspondence (S104,376 “Direct Esterification of Acetic Acid Amine Complexes”). 
We have submitted an abstract for an oral presentation, entitled "The Importance of Utility Systems in Today's and Tomorrow's Biorefineries”, to the $27^{\text {th }}$ Symposium on Biotechnology for Fuels and Chemicals to be held May 1-4, 2005 in Denver, CO. We have been notified that our presentation has been accepted. We currently plan to author a paper based on this presentation and submit the paper for publication in Applied Biochemistry and Biotechnology. 


\section{Conclusions}

1) All tasks of the original proposal were successfully accomplished:

a) The laboratory program for the acetogenic fermentation step showed that the selected could be adapted to a corn steep liquor medium and still produce acetate with industrially relevant yield, concentration and kinetics.

b) An industrially viable recovery scheme to produce acetate esters from near $\mathrm{pH}$ fermentation broths without the production of stoichiometric amounts of a salt co-product was successfully developed.

c) Process and economic models for the indirect route were developed and used to guide the development effort.

2) The projected economics of the Base Case developed in this work are comparable to today's corn based ethanol technology. Sensitivity analysis shows that significant improvements in economics for the indirect route would result if a biomass feedstock rather that starch hydrolyzate were used as the carbohydrate source.

3) The energy ratio, defined as the ratio of green energy produced divided by the amount of fossil energy consumed, is projected to be 3.11 to 12.32 for the indirect route depending upon the details of implementation. Conventional technology has an energy ratio of 1.34, thus the indirect route will have a significant environmental advantage over today's technology. Energy savings of 7.48 trillion Btu/yr will result when $100 \mathrm{MMgal} / \mathrm{yr}$ (neat) of ethanol capacity via the indirect route is placed on-line by the year 2010 . 


\section{Appendix A}

\section{Final Task Schedule}

\section{Final Task Schedule}

\begin{tabular}{|c|c|c|c|c|c|c|}
\hline \multirow{2}{*}{$\begin{array}{c}\text { Task } \\
\text { Number }\end{array}$} & \multirow[b]{2}{*}{ Task Description } & \multicolumn{4}{|c|}{ Task Completion Date } & \multirow[b]{2}{*}{ Progress Notes } \\
\hline & & $\begin{array}{l}\text { Original } \\
\text { Planned }\end{array}$ & $\begin{array}{l}\text { Revised } \\
\text { Planned }\end{array}$ & Actual & $\begin{array}{l}\text { Percent } \\
\text { Complete }\end{array}$ & \\
\hline 1 & Fermentation Step & $6 / 30 / 03$ & $06 / 15 / 05$ & 09/30/04 & $100 \%$ & Completed. \\
\hline 2 & Esterification Step & $12 / 31 / 03$ & $06 / 15 / 05$ & 09/30/04 & $100 \%$ & Completed. \\
\hline 3 & Modeling & $12 / 31 / 03$ & 06/15/05 & 03/31/05 & $100 \%$ & Completed. \\
\hline 4 & Reporting & $3 / 31 / 04$ & 06/15/05 & 04/29/05 & $100 \%$ & Completed. \\
\hline
\end{tabular}

Notes:

1) Original plan assumed a January 1, 2003 start date for Period of Performance. Actual start was delayed to end of June 2003. 


\section{Appendix B}

\section{Final Spending Schedule}

\begin{tabular}{|c|c|c|}
\hline Final Spending Schedule & Project Period: & 06/15/03 to $06 / 15 / 05$ \\
\hline Task & Approved Budget & Final Project Expenditures \\
\hline Task 1 Fermentation Step & 110,000 & 114,443 \\
\hline Task 2 Esterification Step & 115,000 & 119,635 \\
\hline Task 3 Modeling & 60,000 & 91,022 \\
\hline Task 4 Reporting & 15,000 & 22,755 \\
\hline Total & 300,000 & 347,855 \\
\hline DOE Share & 200,000 & 200,000 \\
\hline Cost Share & 100,000 & 147,855 \\
\hline
\end{tabular}




\section{Appendix C}

\section{Final Cost Share Contributions}

Final Cost Share Contributions

\begin{tabular}{|r|c|c|c|c|}
\hline \multirow{2}{*}{ Funding Source } & \multicolumn{2}{|l|}{ Approved Cost Share } & \multicolumn{2}{l|}{ Final Contributions } \\
\cline { 3 - 5 } & Cash & In-Kind & Cash & In-Kind \\
\hline ZeaChem Inc. & & 100,000 & & 147,855 \\
\hline & & & & \\
\hline & & & & \\
\hline Total & & 100,000 & & 147,855 \\
\hline \multicolumn{6}{|c}{ Cumulative Cost Share Contributions } & 147,855 \\
\hline
\end{tabular}




\section{Appendix D}

\section{Energy Savings Metrics}

\section{One Unit of Proposed Technology:}

The process model developed for this grant is based on a grassroots indirect ethanol plant with a $100 \mathrm{MMgal} / \mathrm{yr}$ (denatured) capacity. The plant is provided corn starch hydrolyzate from an across-the-fence corn wet mill. Utilities for the wet-mill are assumed to be provided from fossil resources. All values reported in the Energy Savings Metrics are on a Btu/yr per gal (neat) higher heating value basis. The reported values take into account energy usage for corn production, corn transport, stover production and transport, ethanol conversion, and ethanol distribution.

\section{One Unit of Current Technology:}

The current technology case is reproduced from: Shapouri, H., Duffield, J.A., Wang, M., "The Energy Balance of Corn Ethanol: An Update", United States Department of Agriculture, Agricultural Economic Report Number 814, July, 2002. All values reported in the Energy Savings Metrics are on a Btu/yr per gal (neat) higher heating value basis. The reported values take into account energy usage for corn production, corn transport, stover production and transport, ethanol conversion, and ethanol distribution.

\section{Energy Savings Metrics}

\begin{tabular}{|c|c|c|c|c|c|}
\hline & A & B & $C=A-B$ & D & $E=C x D$ \\
\hline $\begin{array}{c}\text { Type of Energy } \\
\text { Used }\end{array}$ & $\begin{array}{c}\text { Current } \\
\text { Technology } \\
\text { (Btu / yr / unit) }\end{array}$ & $\begin{array}{c}\text { Proposed } \\
\text { Technology } \\
\text { (Btu / yr / unit) }\end{array}$ & $\begin{array}{c}\text { Energy } \\
\text { Savings } \\
\text { (Btu / yr / unit) }\end{array}$ & $\begin{array}{l}\text { Estimated } \\
\text { Number of } \\
\text { Units in U.S. } \\
\text { by } 2010 \\
\text { (units) }\end{array}$ & $\begin{array}{c}\text { Energy Savings } \\
\text { by } 2010 \\
\text { (Btu / yr) } \\
\end{array}$ \\
\hline Fossil Energy & 77,228 & 56,192 & & & \\
\hline $\begin{array}{l}\text { Mill Coproducts } \\
\text { Credit }\end{array}$ & $-14,372$ & $-10,670$ & & & \\
\hline $\begin{array}{c}\text { Net Electricity } \\
\text { Export } \\
\text { (Thermal Equivalent) }\end{array}$ & 0 & $-57,425$ & & & \\
\hline Total Per Unit & 62,856 & $-11,903$ & 74,759 & $100 \times 10^{6}$ & $7.48 \times 10^{12}$ \\
\hline
\end{tabular}

\section{Discussion of Energy Savings:}

See discussion in Task 3 - Modeling for more detail. 


\section{Appendix E Detailed Base Model Description}

This appendix contains a detailed description of the process and utility systems assumed in the base model. Process performance assumptions are based on P90 assumptions for critical process parameters (i.e. the assumptions do not represent observed performance in the laboratory, but are in-line with what should be achieved with a reasonable amount of R\&D effort. In this case, the estimated probability for success of the required R\&D program is $90 \%$ ). The design and economics are based upon nth plant assumptions.

HYSYS v3.2 (Build 5029), a commercial process simulator licensed from Aspen Technologies Inc., was used to perform most of the detailed material and energy balance calculations. A significant portion of the modeling effort was devoted to ensuring that the thermodynamic basis for the model was reasonable. When available, library components were used to represent components in the simulation. A number of components were not available in the library. Table 1 is a list of these components plus the references used to develop the heat of formation and heat capacity data needed the simulator. Table 2 lists the various equilibrium models used in the simulation and provides the basis for the interaction parameters.

Table 3 shows the overall material and energy balance for the simulation, excluding heat cross-exchange for the steam generation system. The non-closure in the overall material balance is $20 \mathrm{lb} / \mathrm{hr}$ out of 56,944,763 lb/hr total (i.e. $0.000036 \%$ non-closure); the non-closure in the overall energy balance is $23,979 \mathrm{Btu} / \mathrm{hr}$ out of $38,152,215,275 \mathrm{Btu} / \mathrm{hr}$ total (i.e. $0.000063 \%$ nonclosure). Most of the non-closure in the material balance can be attributed to round-off errors in reactor operations caused by the level of precision that HYSYS carries in the component molecular weights. Most of the non-closure in the energy balance can be attributed to nonclosure of the recycle operation RCY-4 @FREC. The non-closure in both the material and energy balances is acceptably small on a percentage basis.

The philosophy behind the utility system design in the base case is to maximize power production, with the limitation that the steam system only uses a non-condensing turbine to provide the process steam requirements. In other words, the stover rate to the gasifier was allowed to vary, along with gas turbine size, until the system came into steam balance. At design conditions, slightly over $50 \%$ of the stover is being gasified to provide heat and power. Power in excess of process needs is assumed to be sold to the grid.

Detailed cross-exchanges for the steam generation system were not installed in the simulation because it would increase difficulties with model convergence and decrease the flexibility needed for future process studies. However, it is important to ensure that the model does not lead situations that violate fundamental thermodynamic principles, such as the fact that energy must balance and there needs to be a temperature driving force for heat transfer to occur. Fortunately pinch analysis provides the tools needed for analysis of the steam generation system.

Below is a list of the exchangers that do not have an explicit cross exchange in the simulation: 
$\underline{\text { Hot Sides }}$

E-2101 Combustor Offgas Heat Recovery
E-2200 Conditioned Gas Heat Recovery
E-2204 Regen Offgas Heat Recovery
E-2501 Heat Recovery
E-2502 Heat Recovery
E-3000 HRSG
E-3105 Blowdown Cross Exchanger
E-3107 Desuperheater
E-3108 Desuperheater

\section{Cold Sides}

E-3100 Degasifier Preheater

E-3101 Degasifier Preheater

E-3102 BFW Preheater

E-3101 Steam Generation

E-3104 Superheater

Most of the hot side exchangers are located in either the Gasification and H2 Recovery or Cogeneration sections of the plant, areas where significant amounts of heat are released. This heat is to be used by the cold side exchangers, all of which are located in the Steam System, to generate steam for the non-condensing turbine and process needs.

Figure 1, derived from the pinch analysis, is plot of the composition curves showing the amount of heat available/required versus temperature. Because the two composite curves do not cross and the right hand boundaries of the two composite curves match, the required amount of steam can be generated through cross exchanges. In fact, Figure 1 shows that there is an excess of roughly 111,000,000 Btu/hr of heat available at temperatures below $360^{\circ} \mathrm{F}$. To completely close the energy balance for the plant, one would need to adjust the flue gas exit temperatures slightly upward from their assumed values of $250{ }^{\circ} \mathrm{F}$ to eliminate the $111,000,000 \mathrm{Btu} / \mathrm{hr}$ excess.

Another interesting conclusion drawn from Figure 1 is that there is no reason to include any process exchangers in the pinch analysis that liberate heat at temperatures below $360{ }^{\circ} \mathrm{F}$. For example, the duties for the overhead condensers E-1506, E-1507, E-1603, and E-1604 in the Esterification and Fractionation and Water Management sections are quite large, however the heat is liberated at too low of a temperature to be useful for the steam system. The base case assumes these exchangers use the atmosphere as their heat sink, either directly as air cooled exchangers, or indirectly through the cooling water system.

The rest of this appendix provides a more detailed description process and utility systems. The simulation uses HYSYS's subflowsheet architecture to divide the simulation into logical pieces. Process flow diagrams and material and energy box scores for each of the subflowsheets are provided at the back of this appendix.

\section{Fermentation and Recovery}

The overall responsibility of this area is to convert fermentable carbohydrates into an ester suitable for downstream hydrogenolysis. The tasks performed are further subdivided into: Feed Prep, Fermentation, Pre-Concentration, Acidification, Extraction, Esterification + Fractionation, and Water Management. 
Feed Prep - The various feed materials are mixed in the proper proportions, sterilized and temperature is adjusted prior to sending the media to downstream fermentation. For purposes modeling, the media formulation targets were assumed to be:

$\begin{array}{lc}\text { Fermentable Sugars } & 58.26 \mathrm{~g} / \mathrm{l} \\ \text { Protein } & 5.0 \mathrm{~g} / \mathrm{l} \\ \text { Reductant } & 0.09 \mathrm{~g} / \mathrm{l} \\ \text { Mineral Supplement } & 0.5 \mathrm{~g} / \mathrm{l}\end{array}$

The level of fermentable sugars was set so that the broth would contain $50 \mathrm{~g} / \mathrm{l}$ of acetate (measured as HAc) after fermentation. The primary sugar source is starch hydrolyzate, assumed to be supplied by an "across-the-fence" corn wet mill. The assumed composition for the starch hydrolyzate is shown in Table 4. This is representative of an enzymatic derived hydrolyzate after filtration to remove insoluble protein and fat, essentially an unrefined $95^{+} \mathrm{DE}$ syrup at 30 wt\% dry solids (10). Dextrose, maltose and isomaltose are considered as fermentable sugars; the higher oligomers are not considered fermentable.

The light steep water is the primary nutrient source for the fermentation. Like the starch hydrolyzate, light steep water is assumed to be supplied by an "across-the-fence" corn wet mill. Light steep water is a complex mixture. The assumed composition for light steep water is also given in Table 4, arrived at by simplification of the composition profiles given in the literature $(11,12)$.

It is not clear which component in steep water is the limiting nutrient. For purposes of modeling, we assumed the media formulation would be based on $5 \mathrm{~g} / \mathrm{l}$ of protein. In the lab, we have demonstrated good fermentation performance with yeast extract formulated to a solubles solids content of $10 \mathrm{~g} / \mathrm{l}$, which equivalent to about $5 \mathrm{~g} / \mathrm{l}$ on a protein basis since yeast extract is approximately 50\% protein on a dry basis (11). We have also demonstrated good fermentation performance with corn steep liquor solubles at $30 \mathrm{~g} / \mathrm{l}$, which is equivalent to about $11 \mathrm{~g} / \mathrm{l}$ on a protein basis. We argue that light steep water should be a more active nutrient source compared to corn steep liquor solubles, and good fermentation performance at a protein content of $5 \mathrm{~g} / \mathrm{l}$ should be achievable with a reasonable R\&D effort (i.e. a P50 target).

The fermentation organism is a strict anaerobe. Water typically contains 8-9 ppm dissolved oxygen. While the organism is capable of lowering the redox potential of the media on its own, it is standard practice to provide a reduced media. This can be done using a combination of degassing and the introduction of a reductant to scavenge for dissolved oxygen. In our laboratory work, we use degassing and $\sim 0.75 \mathrm{~g} / \mathrm{l}$ of sodium thioglycolide as the reductant. For purposes of cost modeling, we assumed no degassing and a 10\% excess of sodium sulfite as the reductant. The stoichiometry for this scavenging reaction is:

$$
\mathrm{O}_{2}+2 \mathrm{Na}_{2} \mathrm{SO}_{3} \rightarrow 2 \mathrm{Na}_{2} \mathrm{SO}_{4}
$$

A similar need to remove a trace quantity of dissolved oxygen from a large amount of water is faced in boiler feed water systems. Without pretreatment to remove dissolved oxygen, the generating tubes in the boilers for power plants and other industrial facilities would quickly 
corrode and fail. A number of low-cost reductants have been developed for this application that could potentially be adapted for fermentation media formulation.

Acetogens also require a number of minerals in the media. While we expect that light steep water would provide most of these minerals, additional mineral supplements may become necessary as the concentration of steep water is reduced through $\mathrm{R} \& \mathrm{D}$ efforts. For cost purposes, we assumed that a mineral supplement of $0.5 \mathrm{~g} / \mathrm{l}$ of $\mathrm{KH}_{2} \mathrm{PO}_{4}$ is required.

Two sterilization methods are used. Filter sterilization is used for liquid materials that have a low bioload. These include the dilution water and backset, starch hydrolyzate, reductant and mineral supplements. Heat sterilization is used for feed materials with a high bio-load (e.g. light steep water) and solids content (e.g. Wet Cake and Fresh $\mathrm{CaCO}_{3}$ ). For heat sterilization, the media is heated to $121^{\circ} \mathrm{C}$ and passed through a trombone pipe reactor (i.e. X-1000 Sterilizer) to complete the sterilization.

Fermentation - The fermentation is modeled with a conversion reactor. Table 5 details the stoichiometry assumed for the various reactions. The model assumes a homoacetogen capable of simultaneously converting a variety of fermentables into either acetate or cell mass. The assumed conversion and selectivities are:

$\begin{array}{ll}\text { Fermentables Conversion } & 95 \% \\ \text { Selectivity to Acetate } & 90 \% \\ \text { Selectivity to Cell Mass } & 10 \%\end{array}$

These are defined using the incoming fermentables as the basis. Fermentables include dextrose, fructose, galactose, arabinose, xylose, maltose, isomaltose, and lactate. Higher oligomers from the starch hydrolyzate and ethanol recycled with the backset were not considered to be fermentable.

Our elemental nitrogen balance around the fermentation step is based on a few simplifying assumptions:

1) Overall composition of cell mass can be represented by the formula $\mathrm{CH}_{1.8} \mathrm{O}_{0.5} \mathrm{~N}_{0.2}$ on a dry basis. This is a typical "generic" composition assumed in fermentor design and bioenergetic models $(13,1)$.

2) Ammonia present in the media is preferentially converted to cell mass. Light steep water is a significant source of ammonia.

3) Once ammonia from the feed is exhausted, the cells will then catabolize proteins, peptides, and amino acids in the feed to produce intracellular ammonia and various carbon skeletal fragments. The intracellular ammonia can then participate in the cell synthesis reactions. For purposes of the model, this protein source was assumed to have the formula $\mathrm{C}_{6} \mathrm{H}_{13} \mathrm{O}_{2} \mathrm{~N}$ (i.e. leucine, a dominant amino acid in light steep water).

4) The carbon skeletal fragments produced by amino acid catabolism will be reformed by the cell into intracellular glucose, which can then participate in cell synthesis and acetate production. 
Under the assumptions of the model, the light steep water does not provide enough ammonia to complete cell production. $26.5 \%$ of the incoming proteins, peptides, and amino acids in the feed are catabolized for cell synthesis.

The model assumes adiabatic operation with the fermentor outlet temperature set at 58 ${ }^{\circ} \mathrm{C}$. The fermentation reactions are net exothermic, demonstrated by the fact that the fermentor inlet stream (Stream 1101) has to be adjusted to $49.6^{\circ} \mathrm{C}$ to maintain the required outlet temperature.

A near neutral $\mathrm{pH}$ is maintained by a stoichiometric addition of calcium carbonate to fermentor. Carbon dioxide is liberated when the fermentation is neutralized with calcium carbonate. The carbon dioxide can be present in the form of a separate gas phase, a dissolved gas, or as bicarbonate or carbonate ions in the broth. Stripping the fermentor with an inert gas removes both gaseous and dissolved carbon dioxide and also shifts the aqueous electrolyte equilibrium to reduce the concentration of bicarbonate and carbonate ions in the broth, thereby improving the efficacy of calcium carbonate as a neutralization agent.

The cell mass produced in the fermentation step is removed and concentrated in X-1100 Clarifier. This cell mass is homogenized and then exported back to the host corn wet mill as part of the steep water return stream.

It is too early in the development program to provide a detailed process design for the fermentation and clarification steps. Batch, fed-batch, continuous chemostats, and various cell recycle configurations could potentially be used, but more detailed design information using the truly representative media and organism is needed. For purposes of sizing, a fermentor productivity of $0.5 \mathrm{~g}$ acetate (as HAc) per liter per hour requires 6.2 million gallons of fermentation capacity at $100 \mathrm{MMgal} / \mathrm{yr}$ of denatured ethanol production. Additional volume is needed for gas disengagement, cycles for batch configurations, seed trains, etc., so the model assumes that 10 one million gallon tanks are required. As a point of reference, a one million gallon tank is roughly 60 feet in diameter and 48 feet tall. Tanks at a petroleum refinery tank farm typically range in capacity from 100,000-400,000 barrels, equivalent to 4.2-16.8 million gallons each, so the fermentor volumes assumed in the model are constructible.

Pre-Concentration - The clarified broth from fermentation is concentrated by reverse osmosis from 50 to $80 \mathrm{~g} / \mathrm{l}$ (as HAc). Preconcentrating the broth reduces downstream energy requirements. For purposes of sizing, we assumed a flux of $0.360 \mathrm{~m}^{3} /\left(\mathrm{m}^{2}\right.$ day) and a specific power requirement of $5 \mathrm{kWe} / \mathrm{m}^{3}$ of permeate.

The amount of concentration that can be provided by reverse osmosis is limited either by the osmotic pressure of the retentate or by precipitation/fouling of the membranes. Osmotic pressures are limited to about 600-700 psia, with operating pressures limited to 800-1,000 psia to provide a driving force for separation (14). An electrolyte model of an aqueous calcium acetate solution would show the acetate ion and $\mathrm{Ca}(\mathrm{Ac})^{+}$complex as the dominant ionic species in the solution. Back of the envelope calculations, using the assumption that these are the only ions, results in the conclusion that a 15-20 wt\% calcium acetate solution (as HAc) would have an osmotic pressure of 600-700 psia. We limited the preconcentration of the broth to $80 \mathrm{~g} / \mathrm{l}$ (as 
HAc) since precipitation is likely to be the limiting factor in RO design and operation. Further study is needed to understand the amount of preconcentration that can be achieved by reverse osmosis. This, in turn, is closely tied to the amount of light steep water nutrient required by the fermentation step, so it is not possible to completely decouple future RO process development work from future fermentation media development efforts.

Acidification - The concentrated broth is then cooled to $110^{\circ} \mathrm{F}$, mixed with a stoichiometric amount of tributyl amine (TBA) and fed to V-1302 Acidifier where it is converted to the TBA:HAc complex using carbon dioxide from the fermentation stripping gas plus a small amount of make-up $\mathrm{CO}_{2}$ as the acidification agent. The acidifier is a trayed vessel that conducts the following reaction:

$$
\mathrm{Ca}(\mathrm{Ac})_{2}+2 \mathrm{TBA}+\mathrm{H}_{2} \mathrm{O}+\mathrm{CO}_{2} \rightarrow \mathrm{CaCO}_{3}+2 \mathrm{TBA}: \mathrm{HAc}
$$

The model assumes calcium acetate is the limiting reactant, and assumes $100 \%$ conversion of calcium acetate to the amine complex.

Our laboratory work to date has only used a single stage reactor with a large excess of $\mathrm{CO}_{2}$ blown through the solution. A multi-staged contactor will allow high conversion of the calcium acetate at low excess partial pressures of $\mathrm{CO}_{2}$. Since the inert carrier that accompanies the rich stripping gas from the fermentor is recycled back as the lean stripping gas for fermentation, using a multi-stage contactor to reduce the amount of excess $\mathrm{CO}_{2}$ required for acidification has the effect of reducing the power requirements required for stripping gas circulation. While not the largest power users in the plant, the combined power requirements for stripping gas circulation (C-1300 and C-1301) are responsible for about $11 \%$ of the total power demand for the facility.

Tray design for V-1302 Acidifier requires balancing contacting efficiency with the ability to handle solids. The calcium carbonate produced in the acidification reaction will precipitate as a fine powder in solution. Doughnut trays, shelf trays, or other tray designs capable of handling solids are required.

The bottoms product of the acidifier is filtered to remove the calcium carbonate precipitated. The cake is wash with hot water to displace residual TBA:HAc complex. Wash liquors are combined with the filtrate and sent to downstream extraction. The washed cake is recycled for use as $\mathrm{pH}$ control in fermentation.

The model assumes the acidifier will be capable of reducing the $\mathrm{CO}_{2}$ content of the gaseous product to $1000 \mathrm{ppm}$ mol. The gas is fed to a lime scrubber where the reaction:

$$
\mathrm{Ca}(\mathrm{OH})_{2}+\mathrm{CO}_{2} \rightarrow \mathrm{CaCO}_{3}+\mathrm{H}_{2} \mathrm{O}
$$

lowers the residual $\mathrm{CO}_{2}$ content of the lean stripping gas to $50 \mathrm{ppm}$ mol. As with the acidifier, the trays for the lime scrubber need to be able to handle solids. The spent lime from the scrubber, containing calcium carbonate, is combined with the wet cake from filtration and recycled back to 
the fermentor for $\mathrm{pH}$ control. While lime scrubbers are not as common as caustic scrubbers in industry, a lime scrubber is preferred in this application because there is a use for the spent lime.

Extraction - The aqueous TBA:HAc complex produced by the acidification step is next extracted with a n-pentanol rich organic phase. The TBA:HAc complex is transferred to the organic phase.

Figure 2 plots the equilibrium curve, operating line, and stages for V-1400. Nine theoretical stages at a solvent to feed mass ratio of 0.65 gives a recovery of $98.9 \%$, based on the amount of TBA:HAc present in the aqueous feed. This solvent rate is about 1.3 times the minimum rate. A rotating disk contactor would be a good type of extractor to use for this application.

Esterification + Fractionation - The extract is fed to a reactive distillation unit to produce npentyl acetate according to the reaction:

$$
T B A: H A c+n C_{5} \mathrm{OH} \leftrightarrow n C_{5} A c+H_{2} \mathrm{O}+\mathrm{TBA}
$$

This reversible reaction is conducted in the liquid phase at $\sim 170{ }^{\circ} \mathrm{C}$ and 35.5 psia. The reaction does not proceed appreciably to the right unless water concentration is quite low.

The simulation uses a combination of an ordinary distillation with a recycle conversion reactor to model the esterification unit. Overall conversion is 95\% of theoretical. Figures 3 and 4 plot the equilibrium curve, operating lines, stages and feed qualities for V-1500 Esterifier Column using a pseudo binary analysis on either linear or log axes. The single design specification for the column is the water content of the bottoms product is set at 500 ppm mass. The figures show no excessive pinching and reasonable feed locations.

The esterification unit requires the largest steam load in the base case. The combined duties of Q.E-1503 and Q.V-1501 account for $~ 63 \%$ of the overall steam production for the plant, thus it is important to make sure the esterification unit duties are reasonable. Nearly 88\% of the water that is distilled in V-1500 is free water that was co-extracted with the n-pentanol solvent, with the remaining $12 \%$ balance coming from the water generated by the esterification reaction. The total heating duty is $1556 \mathrm{Btu} / \mathrm{lb}$ of water distilled. This seems to be a reasonable number considering the facts that the heat of vaporization for water is roughly $1000 \mathrm{Btu} / \mathrm{lb}$, some solvent is distilled overhead, there is a heat load for the endothermic heat of reaction, and there is a heat load associated with the work of separation.

The above analysis suggests several ways to lower steam requirements: 1) Switch to a different extraction solvent that does not co-extract as much water, 2) Optimize the PreConcentration and Extraction steps to lower the amount of solvent needed for extraction.

Upon cooing and condensing, the overhead product from the esterification unit phase splits. The organic phase is recycled as solvent for extraction. The aqueous phase is sent downstream to water management where the residual solvent is stripped. 
The bottoms product from the esterification unit is cooled and undergoes a vacuum distillation in V-1503. The column operates at $50 \mathrm{~mm} \mathrm{Hg}$ with a bottoms temperature of $233^{\circ} \mathrm{F}$ and an overhead temperature of $161^{\circ} \mathrm{F}$. Reboiler duty is supplied by cross-exchange with the overhead condenser for V-1500; condenser duty is supplied by cooling water.

Figures 5 and 6 show the equilibrium curve, operating line, stages, and feed quality for V-1503 using a pseudo binary analysis on both linear and reverse log axes. The two design specifications for the column are: 1) The mole fraction of n-pentyl acetate in the bottoms product is 0.04 , and 2) the TBA content of the overhead product is set at $100 \mathrm{ppm}$ mole. The figures show no excessive pinching, reasonable feed location, and that the majority of stages are used to meet the TBA specification for the overhead product.

The bottoms product from $\mathrm{V}$-1503 is cooled and recycled for use as TBA in the acidification step. The overhead product is a mixture of n-pentyl acetate along with the excess npentanol. The mole fraction of n-pentyl acetate in the overhead product is only 0.1956. While one could, in principle, add another column to separate n-pentyl acetate and n-pentanol, this separation is difficult and it is more efficient to just feed the downstream hydrogenolysis step with a dilute feed.

Water Management - The aqueous raffinate and esterification water streams are mixed with a small amount of lime to decompose any residual TBA:HAc complex according to the equation:

$$
\mathrm{TBA}: \mathrm{HAc}+0.5 \mathrm{Ca}(\mathrm{OH})_{2} \rightarrow \mathrm{TBA}+0.5 \mathrm{Ca}(\mathrm{Ac})_{2}+\mathrm{H}_{2} \mathrm{O}
$$

The aqueous stream, which contains dissolved n-pentyl acetate, n-pentanol, and TBA, is fed to $\mathrm{V}$-1600 Water Stripper to remove these contaminants. Figure 7 shows the equilibrium line, operating line, stages, and feed quality for V-1600 using a pseudo binary analysis. The single design specification for the column is the n-pentanol content of the bottoms product is set at 50 ppm mass.

Upon cooling and condensation, the overhead product from V-1600 phase splits. The organic phase is recycled for use as solvent in the extraction step. A portion of the aqueous phase is recycled back to the feed tank, and the rest is taken as a water stream that exported from the plant. It is unrealistic to expect all of the overhead water could be recycled back to the feed tank since light water soluble components such as ammonia and ethanol would build-up to excessive levels.

The stripped water bottoms product from V-1600 is stored and then either used as backset, wash water for the filter cake in the acidification step, or feed for a second reverse osmosis step. This second reverse osmosis step concentrates the solubles to $\sim 42 \mathrm{~g} / \mathrm{l}$, so that when combined with the cell mass the total solids content of the steep water return stream is 6 wt\% (i.e. the same as the solids content of the light steep water feed stream). The permeate water is fairly clean and could be used either as fermentation water, make-up water for the steam or cooling water system, or discharged from the plant. 


\section{Hydrogenolysis}

In the hydrogenolysis unit, the ester is mixed with a large excess of hydrogen, vaporized and superheated, then fed to a packed bed reactor to carry out the reaction:

$$
n \mathrm{C}_{5} \mathrm{Ac}+2 \mathrm{H}_{2} \leftrightarrow n \mathrm{C}_{5} \mathrm{OH}+\mathrm{EtOH}
$$

Our analysis of the results cited in (15) suggests that this reaction can be adequately modeled as an equilibrium reaction when a reduced $\mathrm{CuO} / \mathrm{ZnO}$ catalyst is used. At 20:1 molar ratio of hydrogen to n-pentyl acetate, $200{ }^{\circ} \mathrm{C}$, and 190 psia, a conversion of over $98 \%$ of theoretical will occur with a space velocity of $0.43 \mathrm{hr}^{-1}$ based on liquid n-pentyl acetate feed. The reaction is exothermic. Some of the heat recovered from the reactor effluent is used to drive the reboiler of the downstream fractionation column; the rest is used to preheat the reactor feed.

The excess hydrogen is disengaged from the crude reaction product in V-1701 HP KO Drum. It is the compressed with a centrifugal compressor (C-1700) and recycled. It is unusual to use a centrifugal compressor in a service with a hydrogen rich stream, however in this case the head requirement is low enough $\left(\sim 50,000 \mathrm{ft} \mathrm{lb} / \mathrm{lb}_{\mathrm{m}}\right)$ that a single case centrifugal can be used. From a maintenance point of view, a centrifugal is usually preferred since they have much lower vibration than a reciprocating compressor, and thus have longer periods of operation between scheduled maintenance shutdowns.

The liquid from V-1701 HP KO Drum is then flashed to near ambient pressure across VLV-101 and fed to V-1702 LP KO Drum. The additional vapor formed is cooled in E-1705 LP KO Drum Knockback Condenser to recover additional ethanol from the vapor. Both E-1705 and E-1708 (discussed later) are cooled against a closed loop propane refrigerant cycle.

The liquid from V-1702 LP KO Drum is then flashed an fed to V-1703 Ethanol Splitter. $\mathrm{V}$-1703 operates at $175 \mathrm{~mm} \mathrm{Hg}$ abs with an overhead temperature of $110^{\circ} \mathrm{F}$ and a bottoms temperature of $220^{\circ} \mathrm{F}$. Figures 8 and 9 show the equilibrium curve, operating lines, stages, and feed quality for V-1703 using a pseudo binary analysis on both linear and log axes. The three design specifications for $\mathrm{V}-1703$ are: 1) the mole fraction of ethanol in the overhead liquid product is set at $0.98,2$ ) the mole fraction of n-pentanol in the bottoms product is set at 0.96 , and 3) the temperature of the reflux drum is set at $110^{\circ} \mathrm{F}$. The overhead condenser is actually a partial condenser since there is a small amount of dissolved hydrogen in the column feed. The overhead vapor is cooled further in the knockback condenser E-1708 to recover additional ethanol.

The overhead liquid product from V-1703 is ready for denaturing without further treatment. Notice that the water content of the stream is actually set way back at the esterification step. The bottoms production from V-1703 is recycled for use as solvent in the extraction step. 


\section{Denaturing}

The blending recipe is taken from (16) and is typical for a fuel grade ethanol product. 100 parts by volume of neat ethanol are blended with 5 parts by volume natural gasoline to denature the product. 20 pounds of corrosion inhibitors per thousand barrels of ethanol (PTBE) are also added, and the denatured product is filtered (F-1800) before load out.

\section{Gasification and $\mathrm{H}_{2}$ Recovery}

An indirectly heated biomass gasifier with char combustor and tar reforming capabilities was selected for the base case. Corn stover, with the properties listed in Table 6, was assumed as the feed. The design of the Gasification and H2 Recovery section is similar to that given in the goal case of reference (17). This type of indirectly heated gasifier is currently being licensed by Future Energy Resources Corporation. Capital costs for the Feed Handling, Gasification, and Conditioning areas were scaled from reference (17), so the simulation in these areas is only detailed enough to estimate operating costs and conditioned gas flow rate and composition.

Feed Handling - Minimal handling was assumed since the feedstock is already dry. Tramp metal is removed by magnets, the material is shredded, and then feed downstream to the gasifier. No washing or other processing is assumed

Gasification - The stover is fed to V-2100 Gasifier along with some low pressure steam for fluidization and moderation, plus hot sand recycled from V-2101 Combustor to heat the stover and steam feeds. The gasifier is an entrained bed operating at 23 psia and $1444^{\circ} \mathrm{F}$. The raw gas is disengaged from the circulating sand and char by a series of cyclones (X-2100, X-2101). The circulating sand and char, along with make-up sand and magnesium oxide (used to sequester potassium in the feed) are fed to the combustor (V-2101) where the char is burned in a bubbling bed and the sand temperature is raised to $1849^{\circ} \mathrm{F}$. The circulating sand is disengaged from the combustion offgas and fly ash in X-2103 Combustor Primary Cyclone and returned to V-2100 Gasifier.

Fly ash is disengaged from the combustor offgas by V-2104 Combustor Secondary Cyclone and X-2105 Electrostatic Precipitator. It is cooled, conditioned with small amount of water to control dustiness, and then disposed.

The cleaned combustor offgas is then expanded to near ambient pressure to recover power, and then heat is recovered in E-2101 by raising steam.

Conditioning - The raw gas contains quite a bit of methane and other light hydrocarbons plus heavier tars. These are converted into additional syngas in V-2200 Tar Reformer. Heat for the endothermic reforming reactions is supplied by burning tail gas from the downstream PSA unit plus a small amount of cleaned syngas. Additional power and heat are recovered from the regenerator offgas.

The reformed syngas is cooled to near ambient temperature, the water condensed and knocked out, and then the conditioned gas is sent downstream for compression. The water 
knockout contains some solids and low levels of dissolved species such as ammonia, tars, etc. The solids are removed from the water by sedimentation in X-2200 Clarifier and pumped out for disposal. Likewise, the water overflow from X-2200 is exported.

Compression - The conditioned gas is fed to a multi-case compressor with four interstage cooling circuits plus aftercoolers where it is compressed to an outlet pressure of 285 psia. Most of the heat of compression is ejected directly to the atmosphere by air fin coolers. Interstage temperatures are limited to $300{ }^{\circ} \mathrm{F}$ to prevent thermal degradation of the lubricating oils and maintain high compressor efficiency. Polytropic efficiency was assumed to be $85 \%$, consistent with the improvements in machine efficiency cited in (18) over the past two decades. Water knocked out during compression is exported.

Bulk Desulfurization - Most of the sulfur in the incoming stover is converted to $\mathrm{H}_{2} \mathrm{~S}$ in the gasifier, and then passes through conditioning and compression with the syngas. A LO-CAT II $(19,20)$ skid unit is used to remove the bulk of the $\mathrm{H}_{2} \mathrm{~S}$ and convert it to elemental sulfur. This unit uses a proprietary aqueous chelated iron solution to remove H2S from the gas stream and then uses air to produce an elemental sulfur product plus a regenerated iron solution. For purposes of the economic analysis, the elemental sulfur product is assumed to be stockpiled (i.e. neither a disposal cost nor revenue stream is associated with the material).

H2 Recovery - Some of the syngas is used for fuel (either for the tar reformer regenerator or the gas turbine); the rest is used for hydrogen production and recovery to supply hydrogen for the hydrogenolysis step. Syngas sent to $\mathrm{H} 2$ recovery is preheated to $375{ }^{\circ} \mathrm{C}$, passed over zinc oxide bed to remove the trace levels of H2S that remain after bulk desulfurization, the steam is added and the gas undergoes high temperature and low temperature shift to produce more hydrogen from the carbon monoxide in the syngas according to the equation:

$$
\mathrm{CO}+\mathrm{H}_{2} \mathrm{O} \leftrightarrow \mathrm{CO}_{2}+\mathrm{H}_{2}
$$

After shift, the gas is cooled to $110 \mathrm{~F}$, the water knocked out, and high purity (99.999 \%) hydrogen is recovered by pressure swing adsorption (PSA). The low pressure PSA Offgas is used as fuel in the regenerator for the tar reformer. The high pressure hydrogen product is sent downstream as make-up hydrogen for the hydrogenolysis step.

\section{Cogeneration}

The cogeneration unit consists of a gas turbine topping cycle with heat recovery, plus a non-condensing bottoming cycle steam system that produces both power and process steam requirements.

Gas Turbine - High pressure, low sulfur syngas is combusted in a gas turbine to produce power. The gas turbine is assumed to operate at a pressure ratio of 15, and the turbine inlet air rate is set to limit the gas temperature at the inlet expander to $2420^{\circ} \mathrm{F}$. The exhaust leaves the turbine at $1172{ }^{\circ} \mathrm{F}$. The philosophy behind the utility system design is to maximize power production with the limitation being that non-condensing turbine is used in the steam system with all of the extracted steam being used to meet process needs. Since the utility system design is limited by 
the amount of steam needed by the process, an unfired heat recovery steam generator (HRSG) is used for the gas turbine.

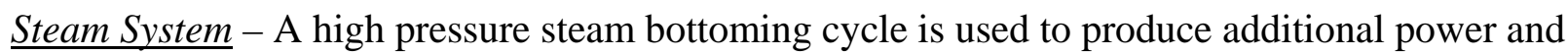
meet the process steam needs. Make-up boiler feed water is de-ionized by ion exchange, preheated, combined with condensate returns and then degasified. Boiler feedwater chemicals (e.g. hydrazine for oxygen scavenging, filming amines for acid gas induced corrosion protection, etc.) are added to the degasifier, then the boiler feed water is pump to pressure and converted to steam. A 2\% blowdown from V-3101 HP Steam Drum is assumed. The saturated steam is superheated so that the turbine inlet conditions are 1250 psig at $100{ }^{\circ} \mathrm{F}$, the highest values proposed by a joint ASME-IEEE committee charged with standardizing steam turbine design conditions (8).

$\mathrm{X}-3100$ is a non-condensing turbine with extraction at 300 psig to provide medium pressure steam for process needs. The turbine exhausts at 50 psig; the exhaust steam is used for low pressure process steam needs. The shift steam and gasifier steam are both exported without desuperheating; the medium pressure and low pressure steam for all other process steam needs are desuperheated before process use. Some low pressure process steam is also generated by letdown of the medium pressure condensate.

\section{Cooling Water}

A standard cooling water system consisting of a tower, circulation pumps, make-up and blowdown systems, and chemical injection for biological growth and corrosion control is used. Table 7 displays the design conditions for the system. The air properties in Table 1 were also used for all fired heater and air cooled exchanger applications in the model.

\section{References}

1) Roels, J.A., Energetics and Kinetics in Biotechnology, Elsevier Biomedical, New York, 1983.

2) Critical Data Tables, $3^{\text {rd }}$ ed., Corn Refiners Association, Washington, DC.

3) Bubnik, Z., Kadlec, P., Urban, D., Bruhns, M., Sugar Technologists Manual, $8^{\text {th }}$ ed., Bartens,, Berlin, 1995.

4) Tamada, J.A., King, C.J., "Extraction of Carboxylic Acids with Amine Extractants. 3. Effect of Temperature, Water Coextraction, and Process Considerations”, Ind. Eng. Chem. Res., Vol. 29, p. 1333-1338, 1990.

5) Wagman, D.D., Evans, W.H., Parker, V.B., Schumm, R.H., Halow, I., Bailey, S.M., Churney, K.L., Nuttall, R.L., The NBS Tables of Chemical Thermodynamic Properties, J. Phys. Chem.

Ref. Data, Vol. II, Supplement No. 2, 1982.

6) Felder, R.M., Rousseau, R.W., Elementary Principles of Chemical Processes, $2^{\text {nd }}$ ed., Wiley, New York, 1986.

7) Oates, J.A.H., Lime and Limestone: Chemistry and Technology, Production and Uses, WileyVCH, New York, 1998.

8) Perry, R.H., Green, D.W, Maloney, J.O. (editors), Perry's Chemical Engineers' Handbook, $7^{\text {th }}$ ed., McGraw-Hill, New York, 1997.

9) Coal Conversion Systems Technical Data Book, Institute of Gas Technology, 1978. 
10) Blanchard, P.H., Technology of Corn Wet Milling and Associated Processes, Elsevier, New York, 1992.

11) Zabriskie, D.W., Armiger, W.B., Phillips, D.H., Albano, P.A., Traders’ Guide to Fermentation Media Formulation, Traders Protein, Memphis, 1980.

12) Hull, S.R, Yang, B.Y., Venzke, D., Kulhavy, K., Montgomery, R., "Composition of Corn Steep Water During Steeping”, J. Agric. Food Chem., Vol. 44, p. 1857-1863, 1996.

13) Bailey, J.E., Ollis, D.F., Biochemical Engineering Fundamentals, $2^{\text {nd }}$ ed., McGraw-Hill, New York, 1986.

14) Seader, J.D., Henley, E.J., Separation Process Principles, Wiley, New York, 1998.

15) Bradley, M.W., Harris, N., Turner, K., "Process for Hydrogenolysis of Carboxylic Acid Esters”, WO 82/03854, Nov. 11, 1982.

16) Renewable Fuels Association, "Fuel Ethanol: Industry Guidelines, Specifications, and Procedures”, RFA Publication 960501, Revised: December 2003, www.ethanol.rfa.org.

17) Spath, P., Eggeman, T., Aden, A., Ringer, M, NREL Report, December 2004 (in press).

18) Kapur, S., Schaider, L., Weyermann, H., "Evolution of Ethylene Plant Compression Systems”, Proceedings of the 12th AIChE Ethylene Producers' Conference, American Institute of Chemical Engineers, New York, 2000.

19) Kohl, A., Nielsen, R., Gas Purification, $5^{\text {th }}$ ed., Gulf Publishing, Houston, 1997.

20) Gas Technology Products, www.gtp-merichem.com. 


\section{Table 1}

\section{Data Sources for Non-Library Components}

Component
Dextrose
Fructose
Galactose
Arabinose
Xylose
Maltose
Isomaltose
Gluc_Olig
N-Soluble
Cell_Mass
Phytate
TBA:HAc
Ca(Ac)2
CaCO3
Ca(OH)2
Ash_Soluble (as CaO)
Sand
Stover
Char-C
Char-H
Char-N
Char-S
Char-O
Char-Ash

Heat of Formation or

Heating of Combustion

Ref. (1), Table 3.7

Ref. (1), Table 3.7

Ref. (1), Table 3.7

Ref. (2), p. 163

Ref. (2), p. 163

Ref. (3), p. 114

Ref. (3), p. 114

Ref. (2), p. 250

Ref. (1), Table 3.7

Ref. (1), Table 3.7

From structure

Ref. (4), Table III

Ref. (5)

Ref. (6), Appendix B

Ref. (6), Appendix B

Ref. (6), Appendix B

Ref. (6), Appendix B

Ref. (9), Boie Correlation

Ref. (9), Boie Correlation

Ref. (9), Boie Correlation

Ref. (9), Boie Correlation

Ref. (9), Boie Correlation

Ref. (9), Boie Correlation

Ref. (9), Boie Correlation

\section{$\underline{\text { Heat Capacity }}$}

Ref. (2), p. 114

Ref. (2), p. 114

Ref. (2), p. 114

From structure

From structure

Ref. (3), p. 114

Ref. (3), p. 114

From structure

From structure

From structure

From structure

From structure

From structure

Ref. (7), p. 20

Ref. (7), p. 207

Ref. (7), p. 119

Ref. (8)., p. 2-186

Ref. (9), IA.30.6 p. 3

Ref. (9), IA.30.6 p. 3

Ref. (9), IA.30.6 p. 3

Ref. (9), IA.30.6 p. 3

Ref. (9), IA.30.6 p. 3

Ref. (9), IA.30.6 p. 3

Ref. (7), p. 119 


\section{Table 2 \\ Equilibrium Model Summary}

Equilibrium Model

UNIQUAC Activity Coefficients w/ Ideal Gas

Peng-Robinson

Sour Peng-Robinson

(Uses Wilson's API Sour

Water method to account for aqueous phase ionization of $\mathrm{H} 2 \mathrm{~S}$,

$\mathrm{CO} 2$, and $\mathrm{NH} 3$ )

Peng-Robison StryjekVera

ASME Steam Tables

\section{$\underline{\text { Subflowsheet Areas }}$}

Main, Fermentation+Recovery, Feed Prep, Fermentation, PreConcentration, Acidification, Lime Scrubber, Filtration,

Esterification+Fractionation (non-LLE areas), Water Management (non-LLE areas), Reverse Osmosis

\section{Extraction,}

Esterification+Fractionation

(LLE areas), Water

Management (LLE areas)

Refrigeration, Cogeneration, Gas Turbine, Cooling Water

Gasification+H2 Recovery, Feed Handling, Gasification, Conditioning, Compression, Bulk Desulfurization, $\mathrm{H} 2$

Recovery, ZnO Beds, PSA

Hydrogenolysis, Denaturing

Steam System

\section{Basis for Interaction Parameters}

HYSYS defaults or estimated from structure.

Cross checked HYSYS predicted VLE against published data for following binaries: $\mathrm{H} 2 \mathrm{O}-\mathrm{nC} 5 \mathrm{OH}, \mathrm{nC} 5 \mathrm{OH}-\mathrm{nC} 5 \mathrm{Ac}$.

Checked HYSYS predicted VLE "reasonableness" for following binaries: $\mathrm{H} 2 \mathrm{O}-\mathrm{nC} 5 \mathrm{Ac}, \mathrm{H} 2 \mathrm{O}-\mathrm{TBA}$, nC5Ac-TBA, nC5OH-TBA

Fitted experimental data for: H2O-TBA:HAc-nC5OH ternary, H2O-nC5OH binary; Otherwise used HYSYS defaults or estimated from structure.

Check HYSYS predicted LLE "reasonableness" for following binaries: H2O-nC5Ac, H2O-TBA

HYSYS Defaults

HYSYS Defaults

HYSYS Defaults

Not Applicable 
DE-FG36-03G013010

ZeaChem, Inc.

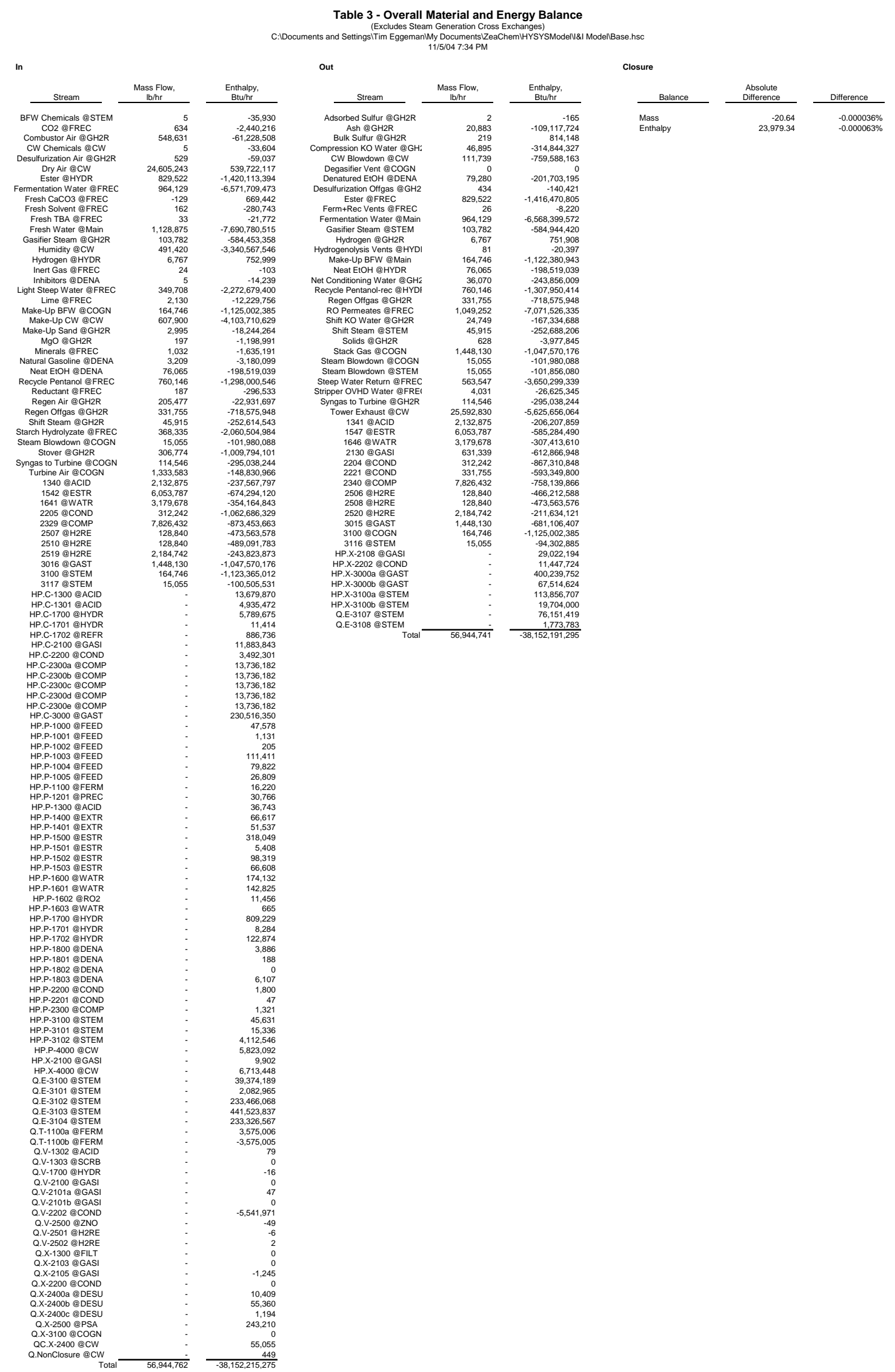


Table 4

Model Composition for

Starch Hydrolyzate and Light Steep Water

\section{Starch Hydrolyzate}

Dry Solids, wt $\%$

Component

Dextrose

Maltose

Isomaltose

Higher Oligomers

Total
30

$\underline{\mathrm{Wt} \%}$ (Dry Basis)

96.0

1.0

1.2

1.8

100

\section{Light Steep Water}

Dry Solids, wt $\%$

6

Component $\quad \underline{\text { Wt\% (Dry Basis) }}$

N-Soluble

37.8

Lactate (as Acid)

26.0

Ammonia

4.2

Phytate

7.8

Dextrose

4.9

Fructose

3.64

Galactose

3.5

Arabinose

1.68

Xylose

0.28

Ash

10.2 


\section{Table 5 \\ Amino Acid Catabolism, Cell Synthesis and Acetate Production Reactions}

Amino Acid

Catabolism:

$\mathrm{C}_{6} \mathrm{H}_{13} \mathrm{O}_{2} \mathrm{~N}+1.5 \mathrm{CO}_{2}+2.5 \mathrm{H}_{2} \mathrm{O} \rightarrow \mathrm{NH}_{3}+1.25 \mathrm{C}_{6} \mathrm{H}_{12} \mathrm{O}_{6}$

Cell Synthesis:

Six Carbon

Sugars

$\mathrm{C}_{6} \mathrm{H}_{12} \mathrm{O}_{6}+\frac{0.2}{0.175} \mathrm{NH}_{3} \rightarrow \frac{1}{0.175} \mathrm{CH}_{1.8} \mathrm{O}_{0.5} \mathrm{~N}_{0.2}+\frac{0.05}{0.175} \mathrm{CO}_{2}+\frac{0.45}{0.175} \mathrm{H}_{2} \mathrm{O}$

Five Carbon

$\mathrm{C}_{5} \mathrm{H}_{10} \mathrm{O}_{5}+\frac{0.2}{0.21} \mathrm{NH}_{3} \rightarrow \frac{1}{0.21} \mathrm{CH}_{1.8} \mathrm{O}_{0.5} \mathrm{~N}_{0.2}+\frac{0.05}{0.21} \mathrm{CO}_{2}+\frac{0.45}{0.21} \mathrm{H}_{2} \mathrm{O}$

Sugars

Dimer

Sugars

$\mathrm{C}_{12} \mathrm{H}_{22} \mathrm{O}_{11}+\frac{0.2}{0.0875} \mathrm{NH}_{3} \rightarrow \frac{1}{0.0875} \mathrm{CH}_{1.8} \mathrm{O}_{0.5} \mathrm{~N}_{0.2}+\frac{0.05}{0.0875} \mathrm{CO}_{2}+\frac{0.3625}{0.0875} \mathrm{H}_{2} \mathrm{O}$

Lactate

(as Acid)

$$
\mathrm{C}_{3} \mathrm{H}_{6} \mathrm{O}_{3}+\frac{0.2}{0.35} \mathrm{NH}_{3} \rightarrow \frac{1}{0.35} \mathrm{CH}_{1.8} \mathrm{O}_{0.5} \mathrm{~N}_{0.2}+\frac{0.05}{0.35} \mathrm{CO}_{2}+\frac{0.45}{0.35} \mathrm{H}_{2} \mathrm{O}
$$

Acetate Production:

Six Carbon

$\mathrm{C}_{6} \mathrm{H}_{12} \mathrm{O}_{6}+1.5 \mathrm{CaCO}_{3} \rightarrow 1.5 \mathrm{Ca}(\mathrm{Ac})_{2}+1.5 \mathrm{CO}_{2}+1.5 \mathrm{H}_{2} \mathrm{O}$

Sugars

Five Carbon

$\mathrm{C}_{5} \mathrm{H}_{10} \mathrm{O}_{5}+1.25 \mathrm{CaCO}_{3} \rightarrow 1.25 \mathrm{Ca}(\mathrm{Ac})_{2}+1.25 \mathrm{CO}_{2}+1.25 \mathrm{H}_{2} \mathrm{O}$

Sugars

Dimer

Sugars

$$
\mathrm{C}_{12} \mathrm{H}_{22} \mathrm{O}_{11}+3 \mathrm{CaCO}_{3} \rightarrow 3 \mathrm{Ca}(\mathrm{Ac})_{2}+3 \mathrm{CO}_{2}+2 \mathrm{H}_{2} \mathrm{O}
$$

Lactate

(as Acid)

$$
\mathrm{C}_{3} \mathrm{H}_{6} \mathrm{O}_{3}+0.75 \mathrm{CaCO}_{3} \rightarrow 0.75 \mathrm{Ca}(\mathrm{Ac})_{2}+0.75 \mathrm{CO}_{2}+0.75 \mathrm{H}_{2} \mathrm{O}
$$




\section{Table 6 \\ Model Composition for Stover}

Ultimate Analysis:

\author{
Carbon \\ Hydrogen \\ Nitrogen \\ Sulfur \\ Oxygen \\ Ash
}

Total

Proximate Analysis:

Moisture

Fixed Carbon

Volatile Carbon

Ash
Wt \%, (dry basis)

44.00

5.61

0.62

0.09

43.58

6.10

$10 \overline{00.00}$

$\underline{\mathrm{Wt} \%}$

15.00

21.55

58.26

5.19

Total 


\section{Table 7 \\ Cooling Water System Design Basis}

Cooling Water Specifications:

Supply Conditions

Return Conditions

Ambient Air Conditions:

Other: $90^{\circ} \mathrm{F}$ at 50 psig

$110^{\circ} \mathrm{F}$ at 45 psig

Pressure
Dry Bulb Temperature
Wet Bulb Temperature
Composition
Nitrogen
Oxygen
Argon
Carbon Dioxide
Water
Total

Drift

Cycles of Concentration Chemical Usage

Tower L/G
1 Atm

$90{ }^{\circ} \mathrm{F}$

$80^{\circ} \mathrm{F}$

Mole Fraction

0.756556

0.202943

0.009049

0.000339

0.031113

1.000000

$0.2 \%$ of Water In 5

2.0E-07 lb/lb circulation 1.0 
Figure 1 - Composite Curves for Steam Generation System

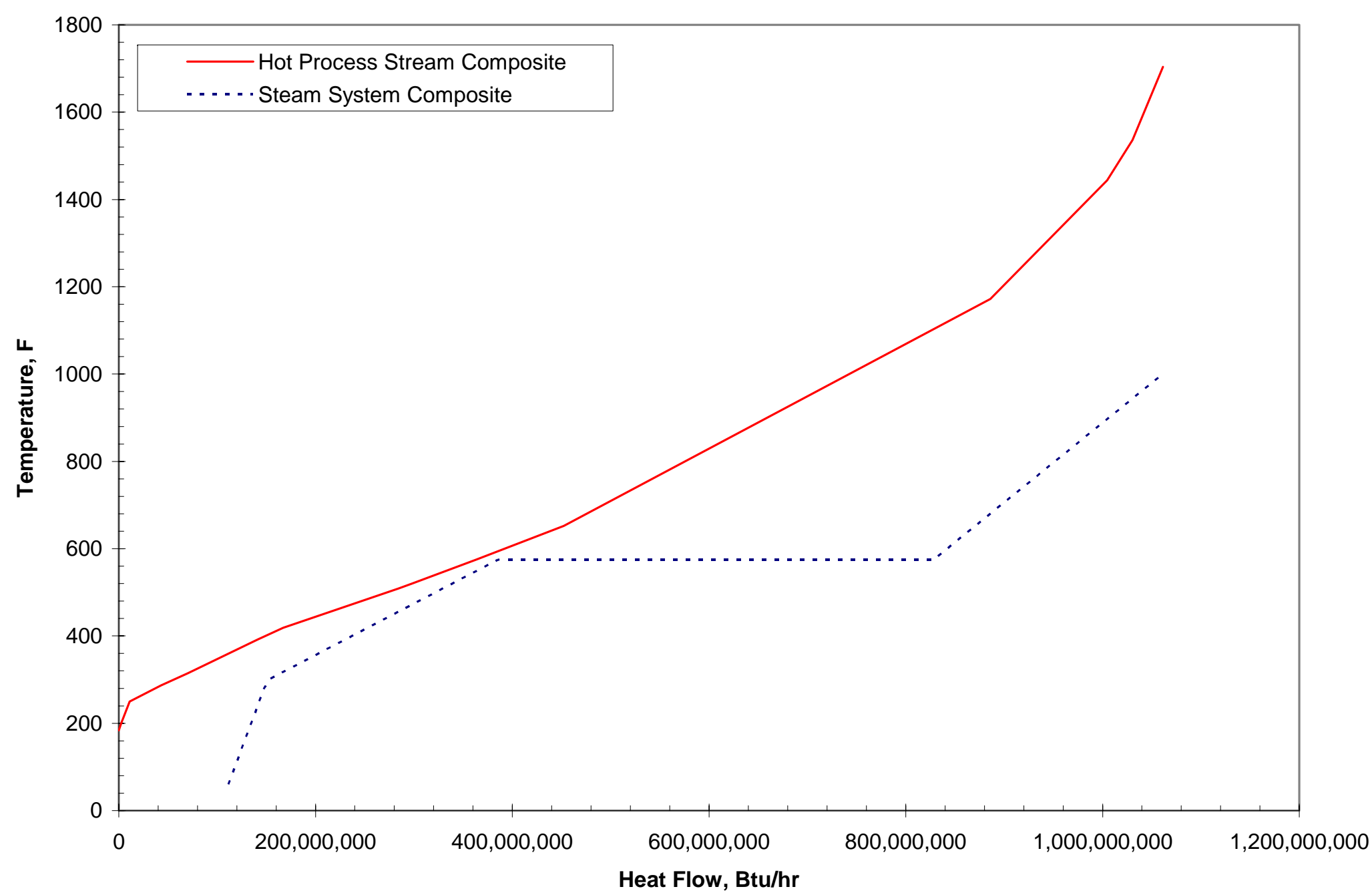


Figure 2 - Process Design for V-1400 Extractor

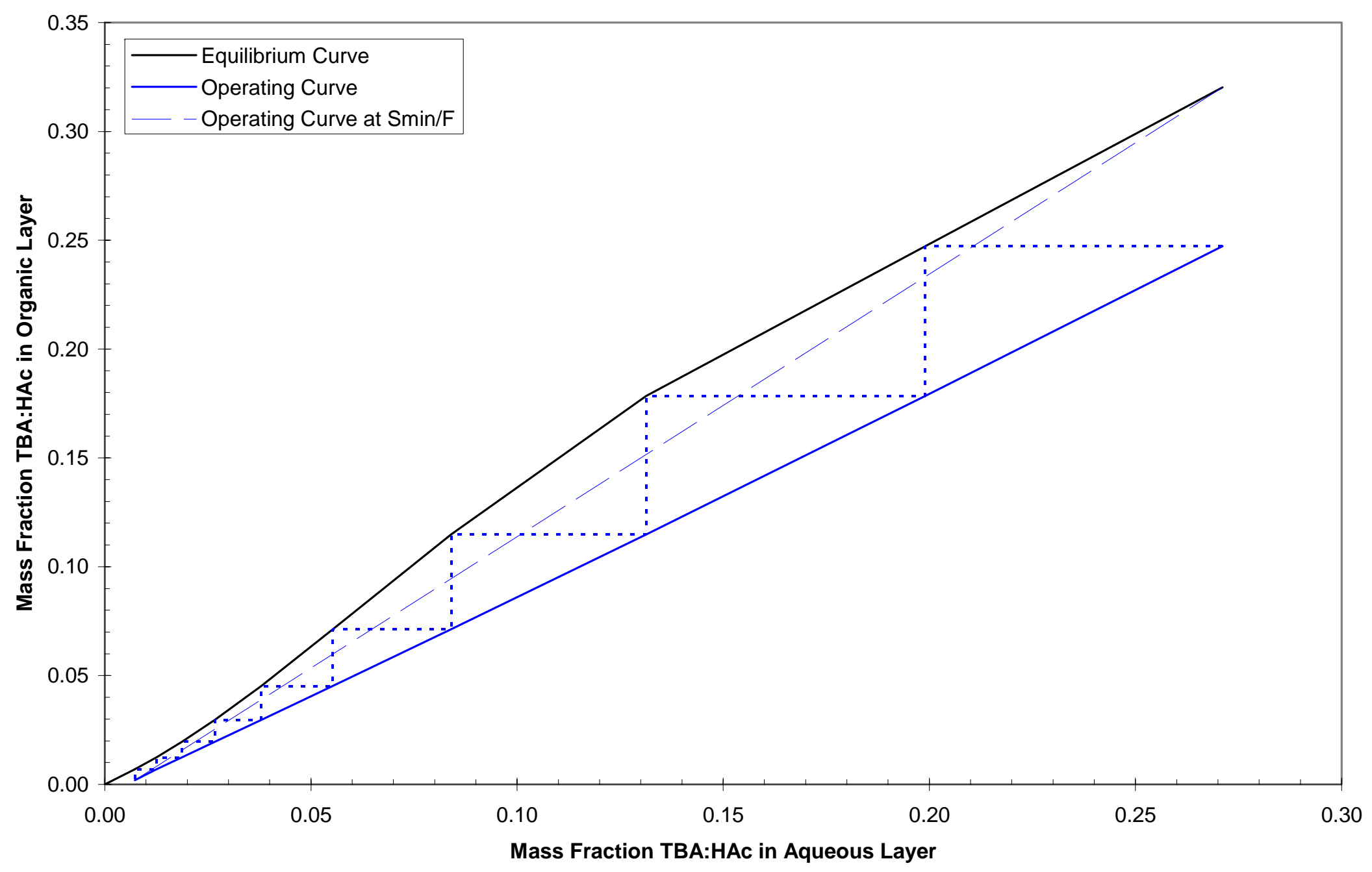


Figure 3 - Process Design for V-1500 Esterifier Column

(Pseudo Binary Analysis, Light Keys $=\mathrm{H}_{2} \mathrm{O}$ and Lighter)

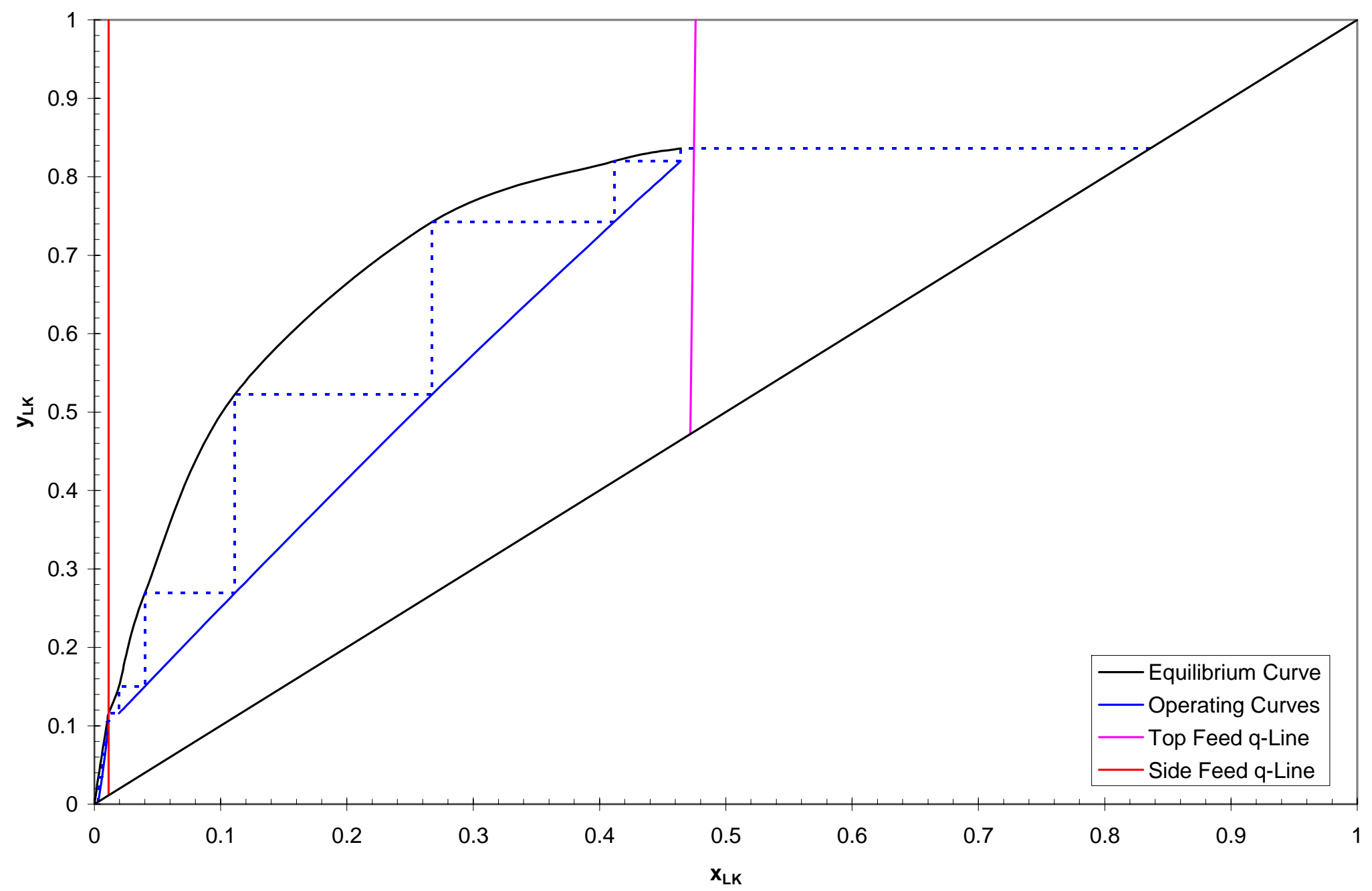




\section{Figure 4 - Process Design for V-1500 Esterifier Column}

(Pseudo Binary Analysis, Light Keys $=\mathrm{H}_{2} \mathrm{O}$ and Lighter)

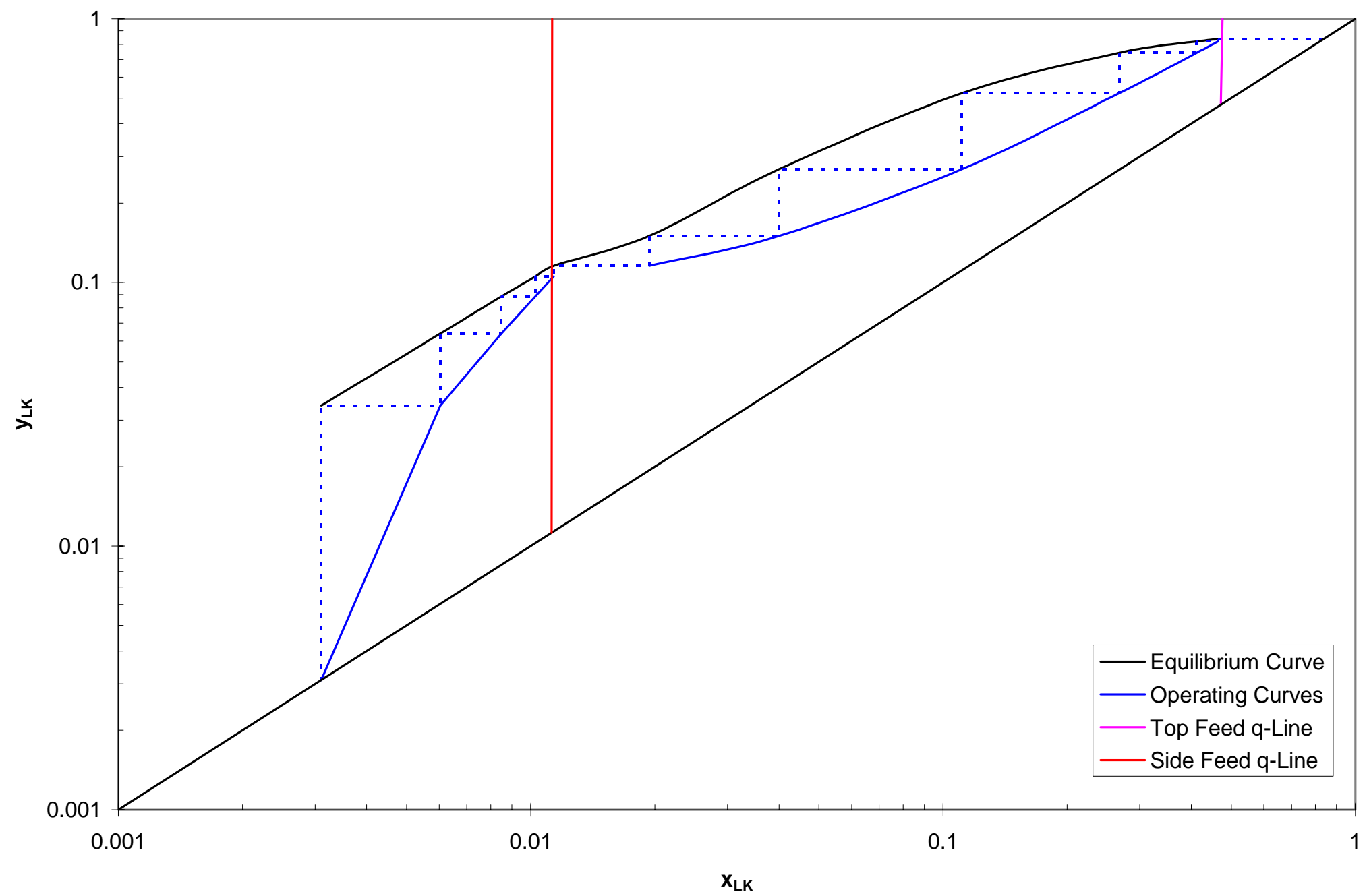


Figure 5 - Process Design for V-1503 TBA Splitter

(Pseudo Binary Analysis, Light Keys $=\mathrm{nC}_{5} \mathrm{Ac}$ and lighter)

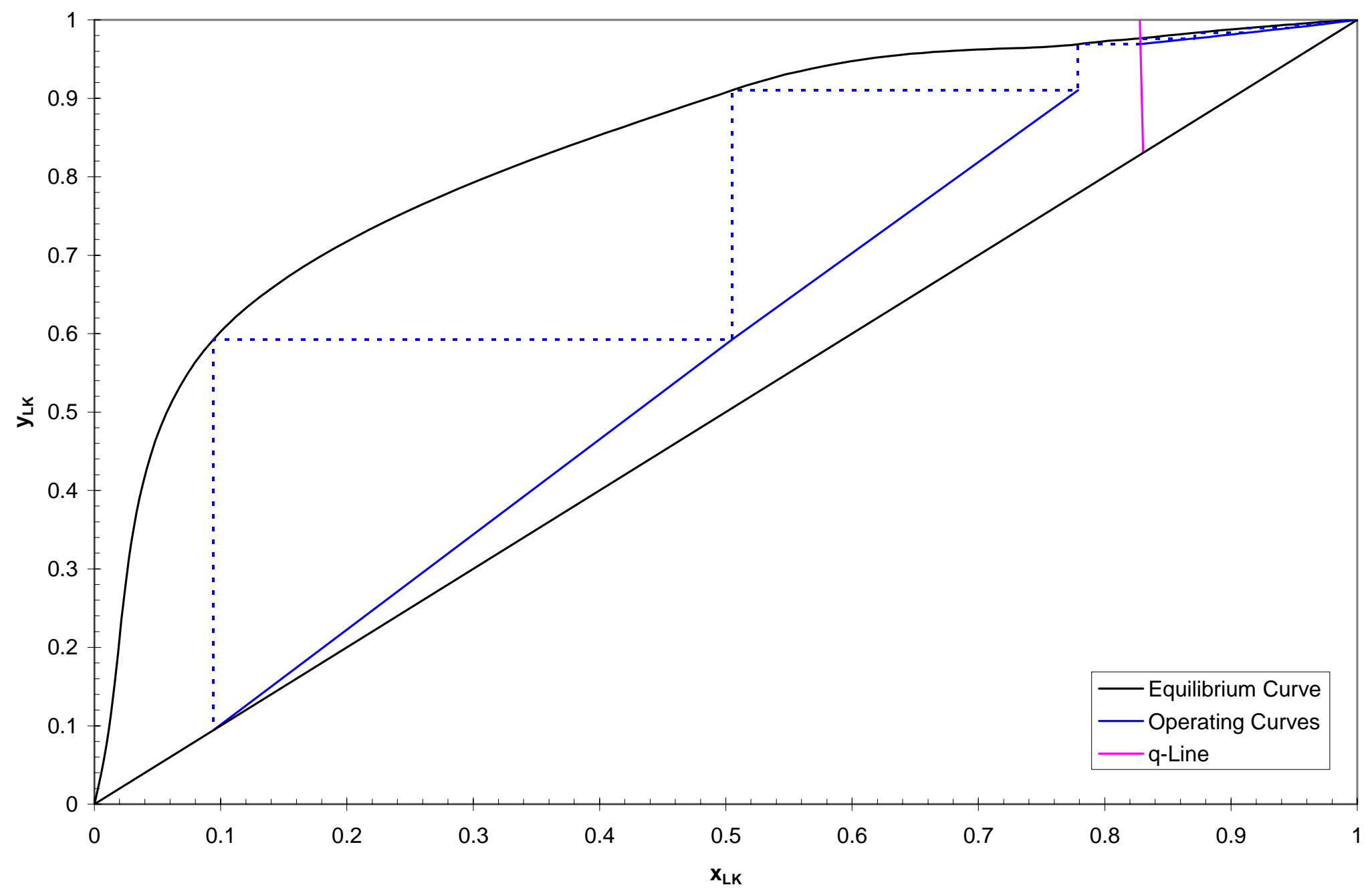


Figure 6 - Process Design for V-1503 TBA Splitter

(Pseudo Binary Analysis, Heavy Keys $=$ TBA and heavier)

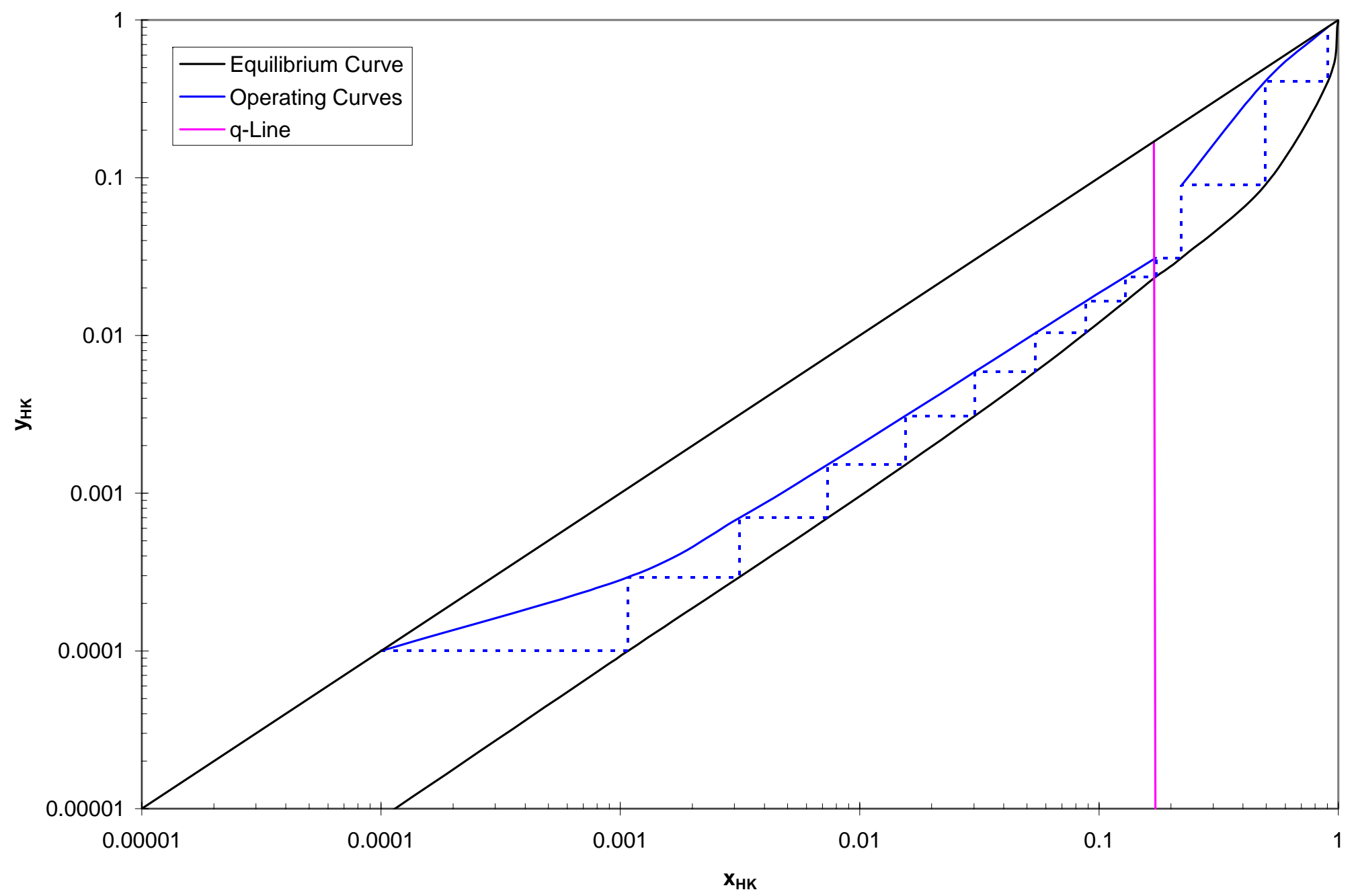


Figure 7 - Process Design for V-1600 Water Stripper

(Pseudo Binary Analysis, Light Keys $=\mathrm{EtOH}+\mathrm{nC}_{5} \mathrm{AC}+\mathrm{nC}_{5} \mathrm{OH}+\mathrm{TBA}+$ Light Gases)

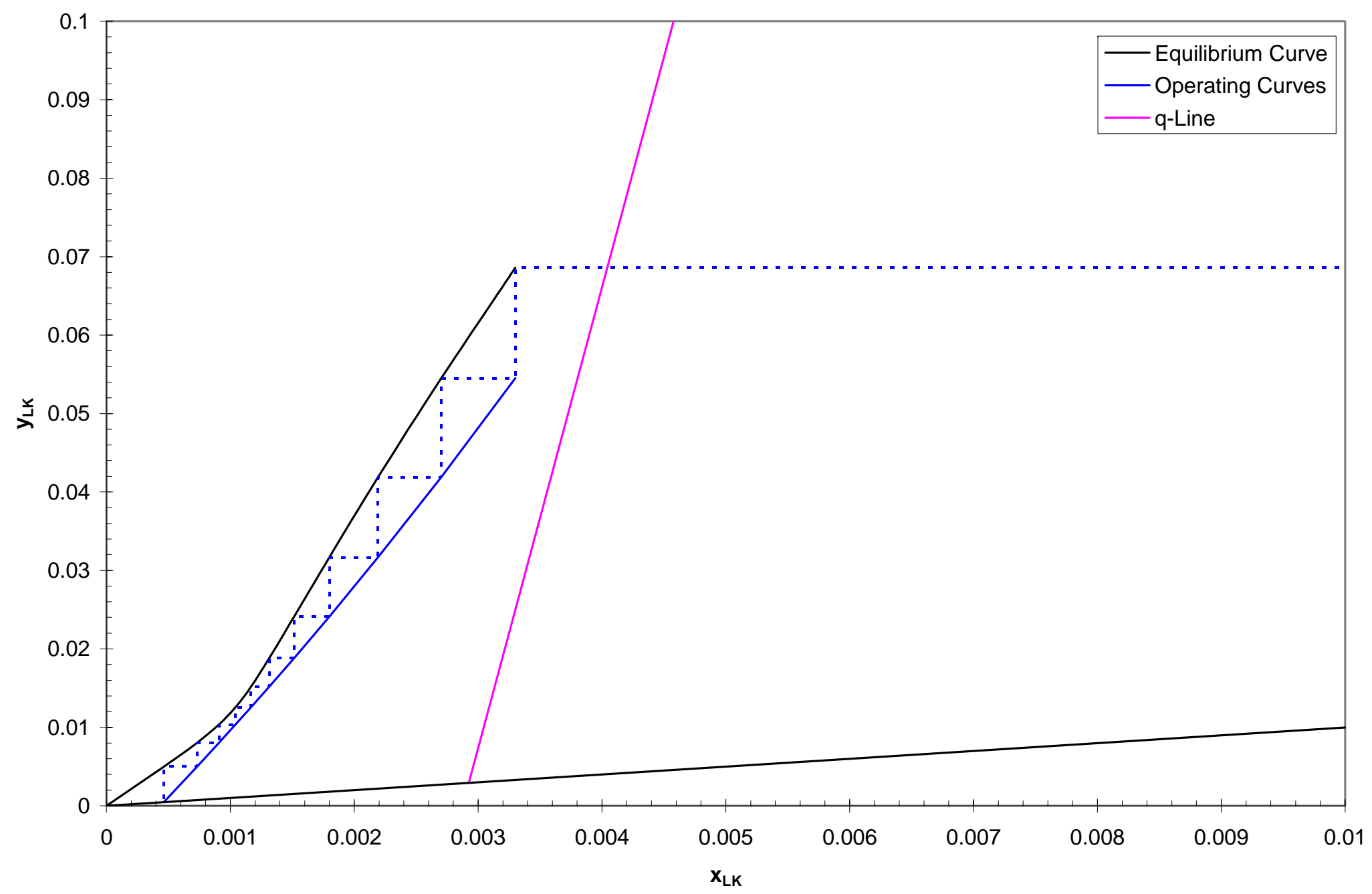


Figure 8 - Process Design for V-1703 Ethanol Splitter

(Pseudo Binary Analysis, Light Keys $=\mathrm{H}_{2}+\mathrm{CO}+\mathrm{H}_{2} \mathrm{O}+\mathrm{EtOH}$ )

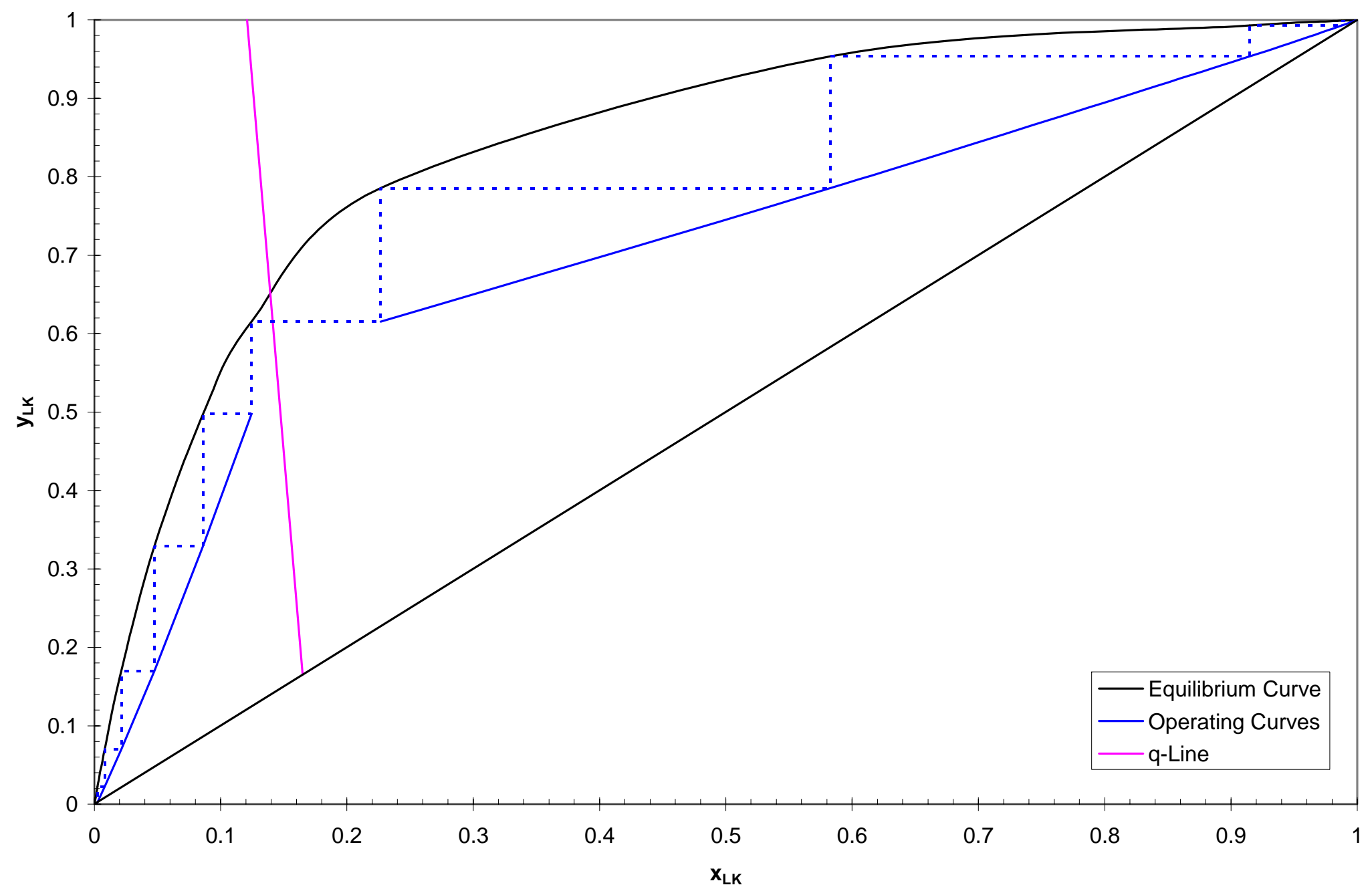


Figure 9 - Process Design for V-1703 Ethanol Splitter

(Pseudo Binary Analysis, Light Keys $=\mathrm{H}_{2}+\mathrm{CO}+\mathrm{H}_{2} \mathrm{O}+\mathrm{EtOH}$ )

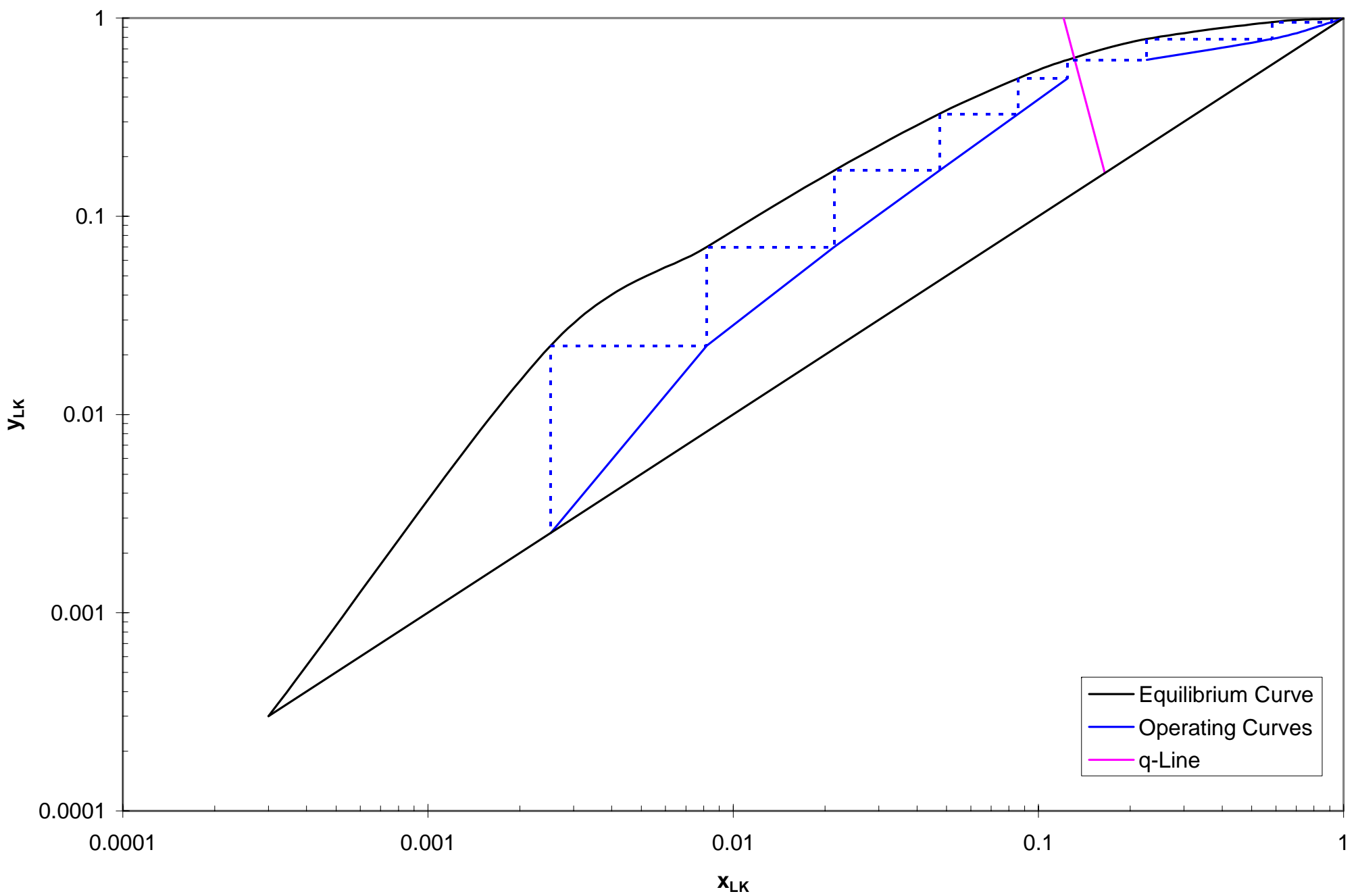


DE-FG36-03G013010

ZeaChem, Inc.
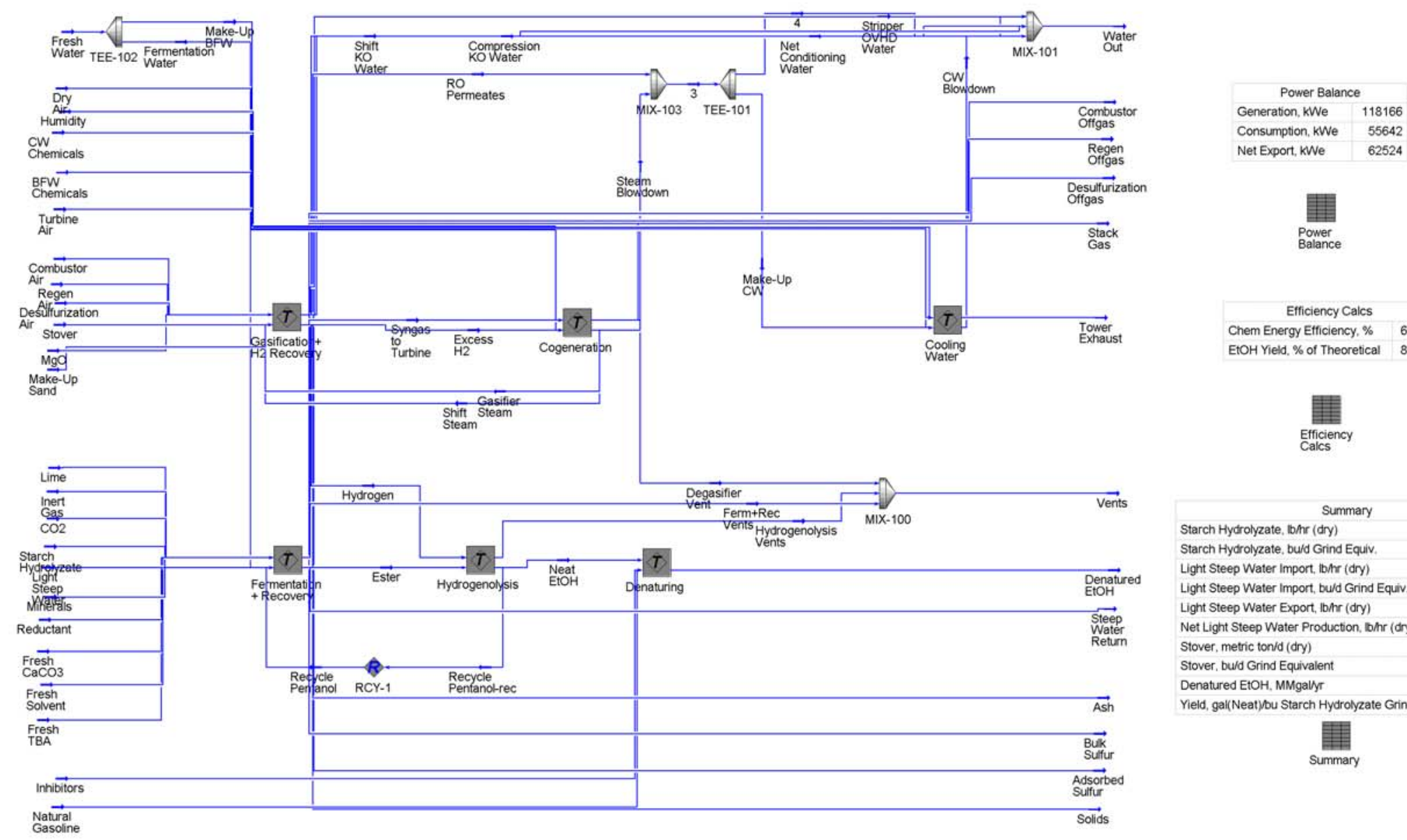

Efficiency Calcs Chem Energy Efficiency. \% 66.85 EtOH Yield, \% of Theoretical 34.0

\begin{tabular}{|c|c|}
\hline \multicolumn{2}{|l|}{ Summary } \\
\hline Starch Hydrolyzate, Ib/hr (dry) & 110500 \\
\hline Starch Hydrolyzate, bu/d Grind Equiv. & 74286 \\
\hline Light Steep Water Import, ibhr (dry) & 20982 \\
\hline Light Steep Water Import, buidd Grind Equiv. & 162760 \\
\hline Light Steep Water Export, IbMr (dry) & 33813 \\
\hline Net Light Steep Water Production, Bb/rr (dry) & 12830 \\
\hline Stover, metric ton/d (dry) & 2839 \\
\hline Stover, bu/d Grind Equivalent & 224106 \\
\hline Denatured EtOH, MMgalyr & 100.0 \\
\hline Yield, gal(Neat) $)$ Su Starch Hydrolyzate Grind Equiv & 3.693 \\
\hline
\end{tabular}


DE-FG36-03G013010

Flowsheet: Case (Main)

ZeaChem, Inc.

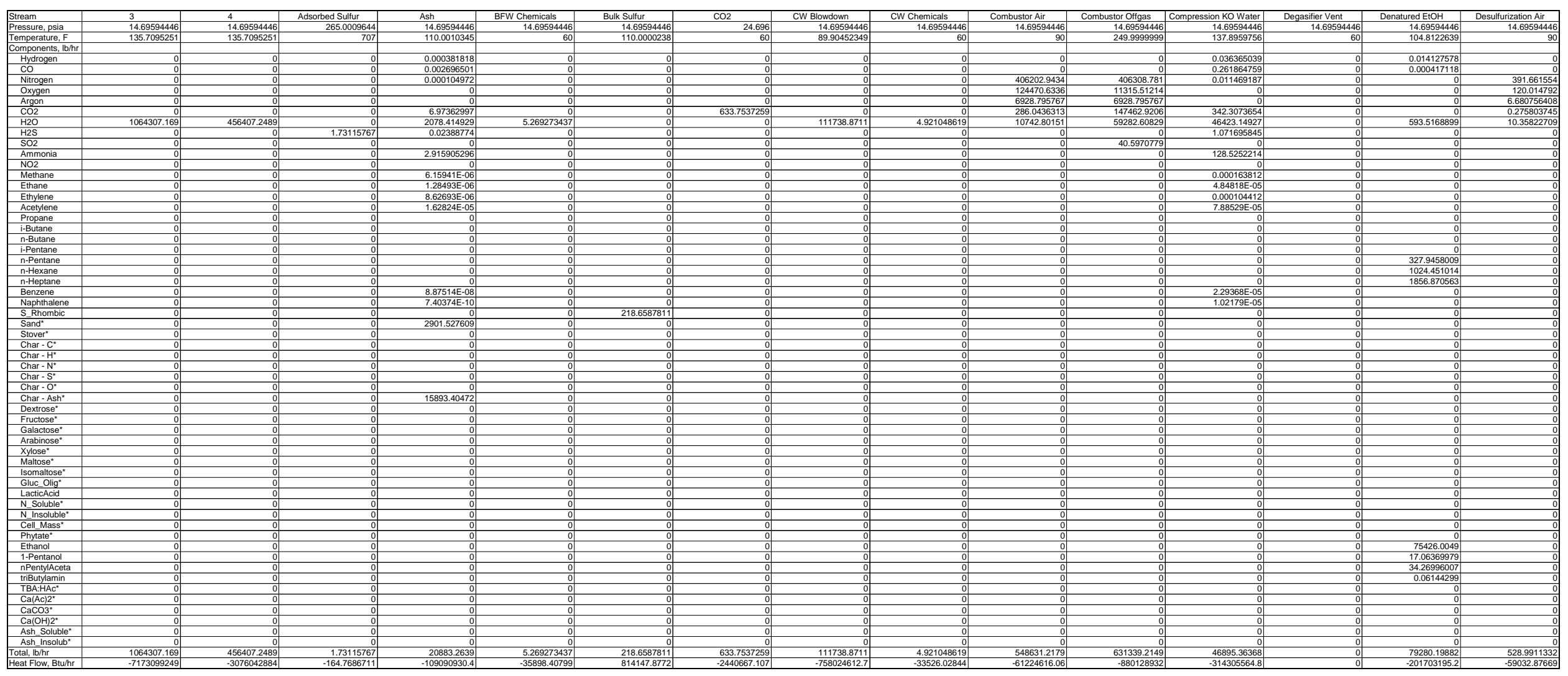


DE-FG36-03G013010

ZeaChem, Inc.

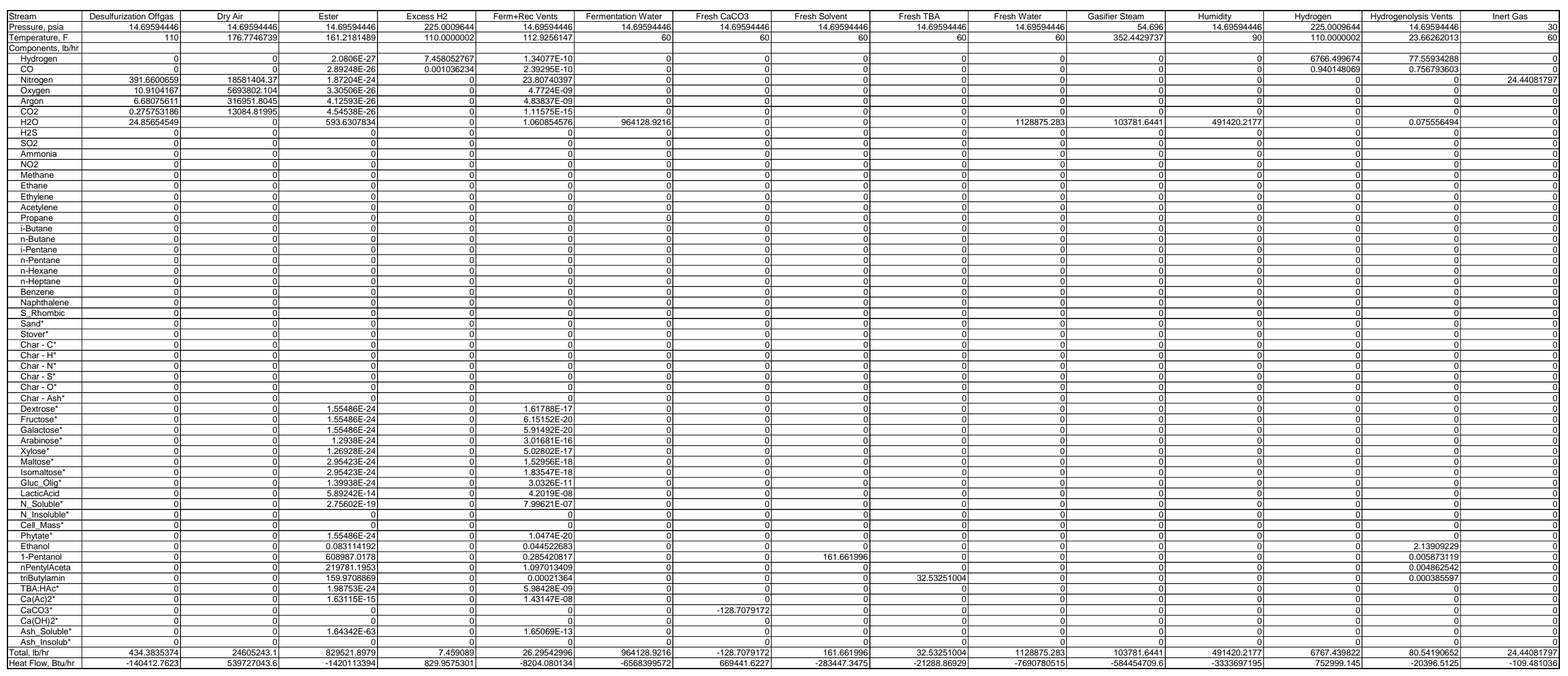


DE-FG36-03GO13010

ZeaChem, Inc.

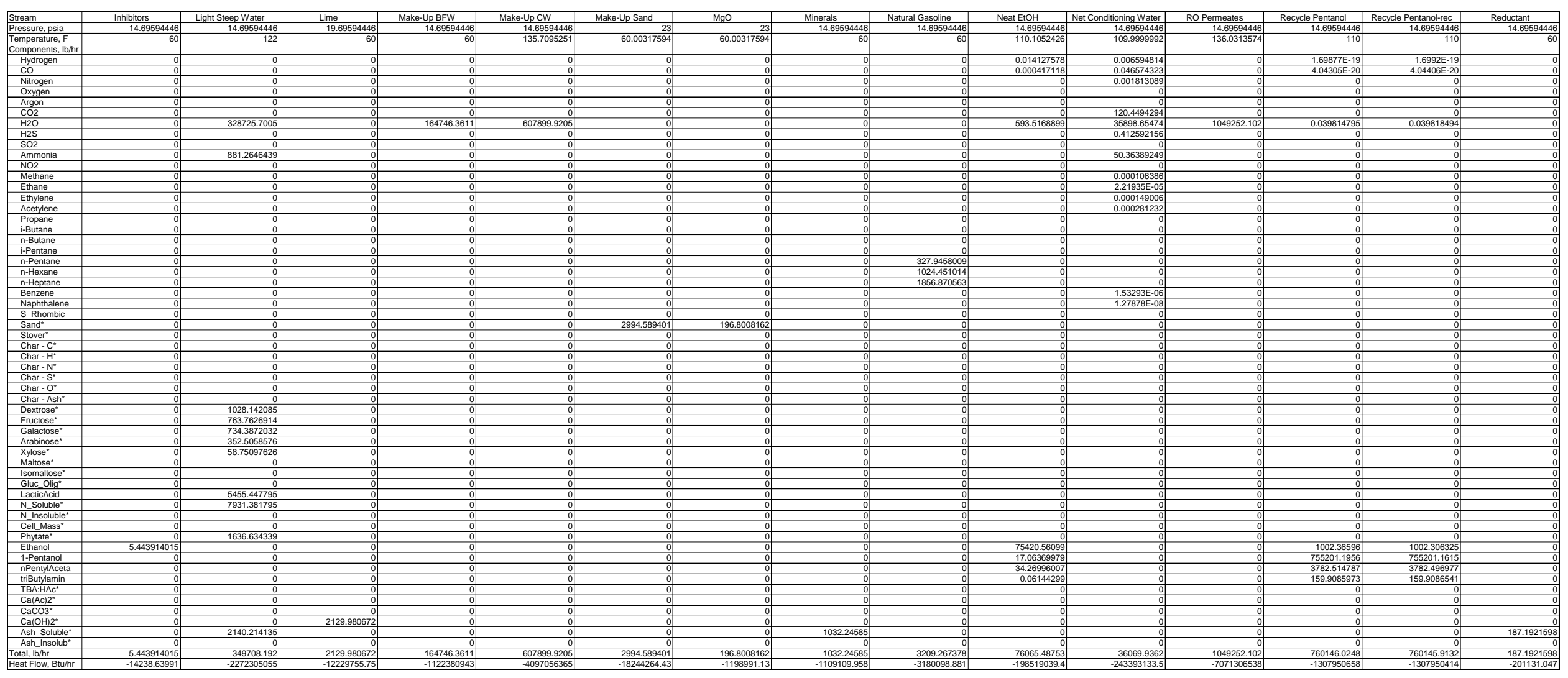


DE-FG36-03G013010

ZeaChem, Inc.

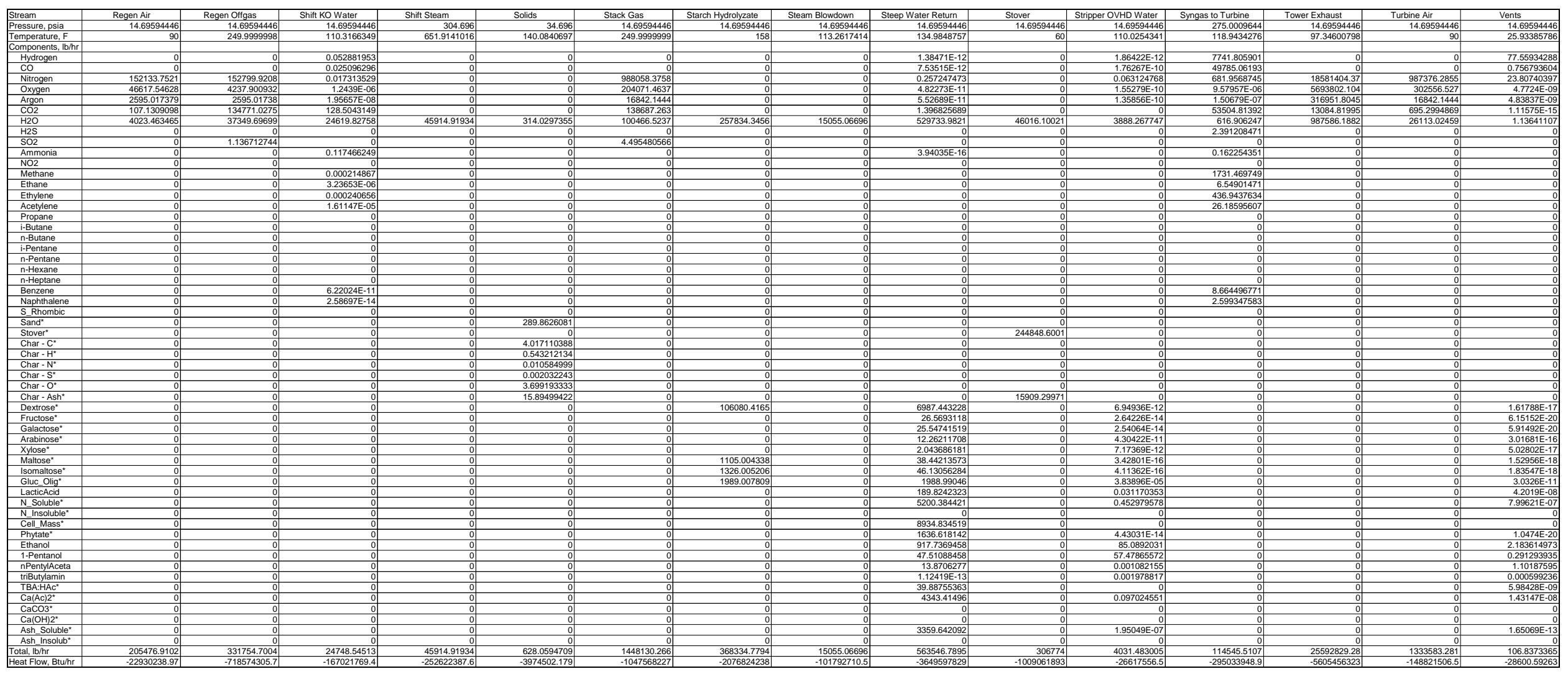


DE-FG36-03G013010

ZeaChem, Inc.

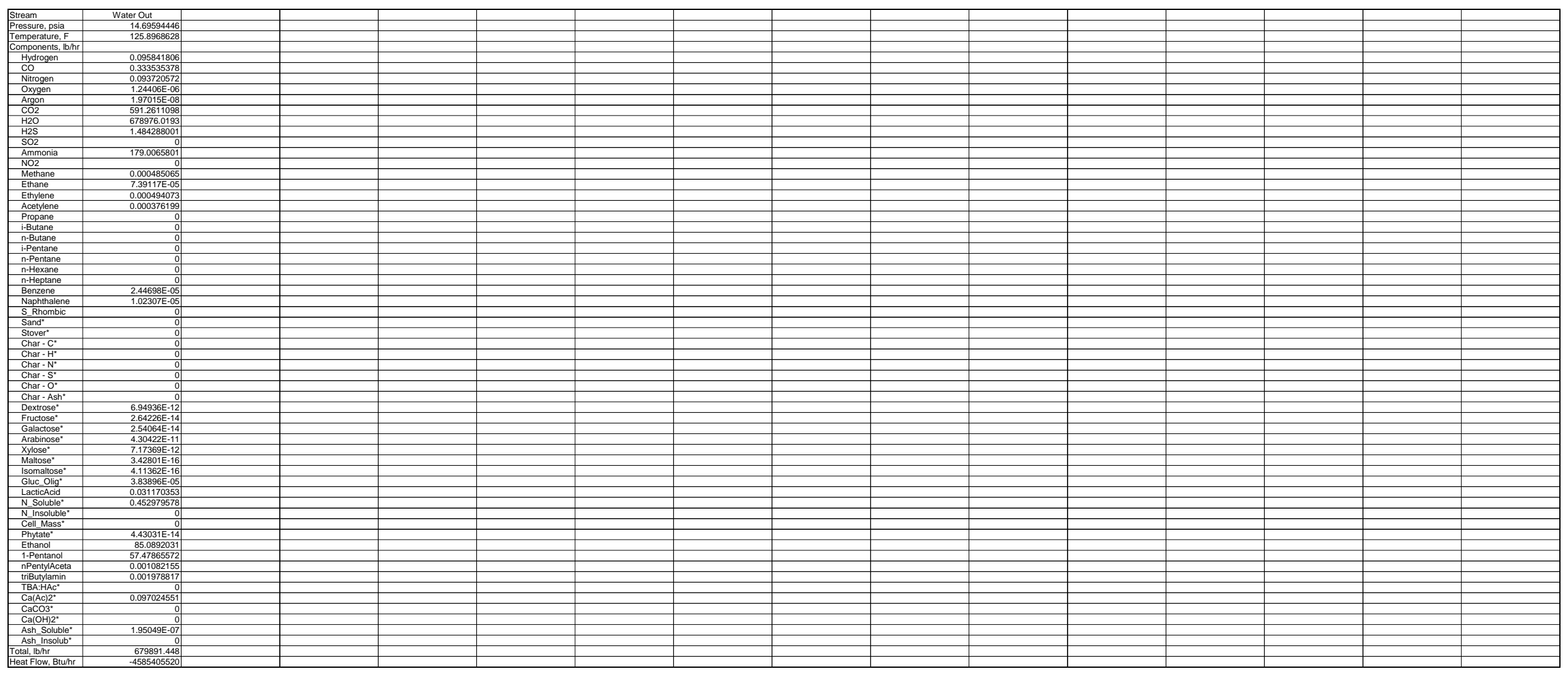


DE-FG36-03G013010

ZeaChem, Inc.

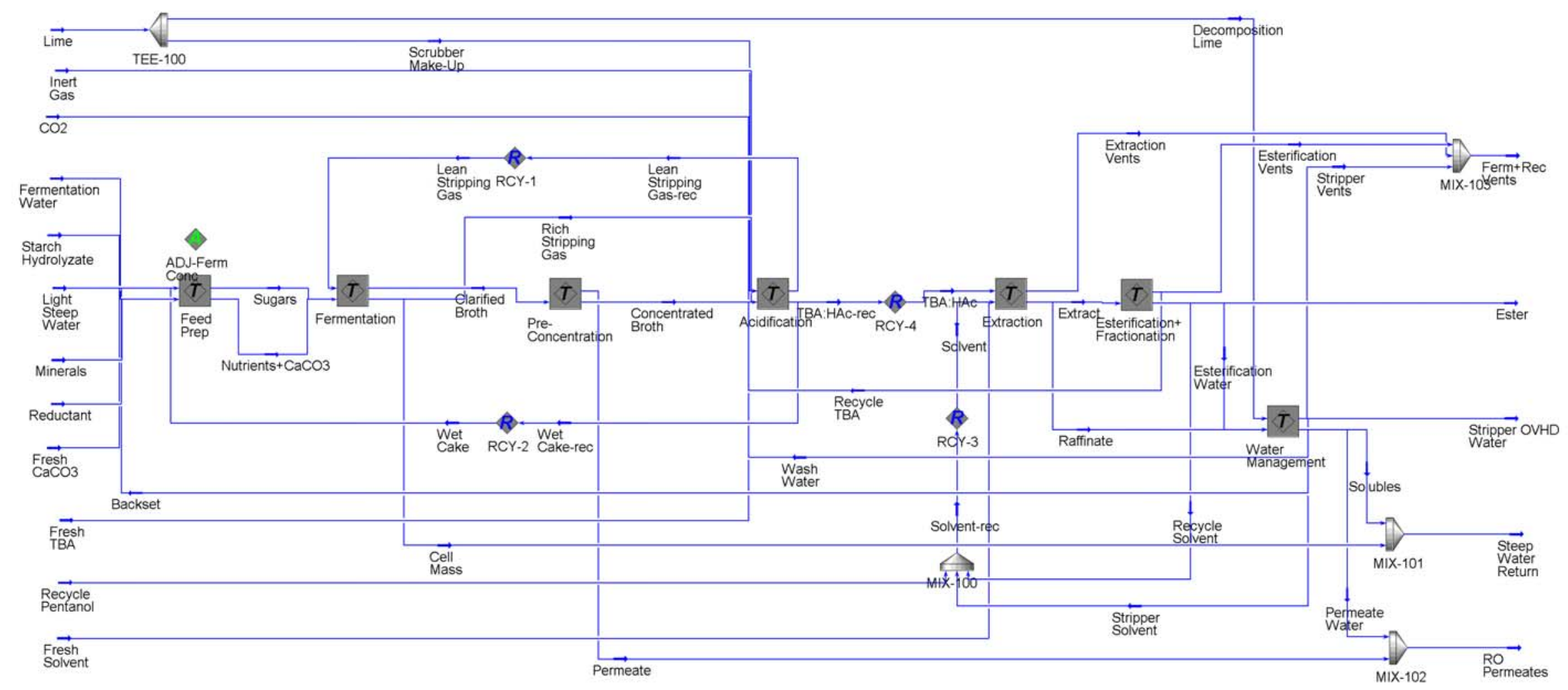


DE-FG36-03G013010

Flowsheet: Fermentation + Recovery (FREC)

ZeaChem, Inc.

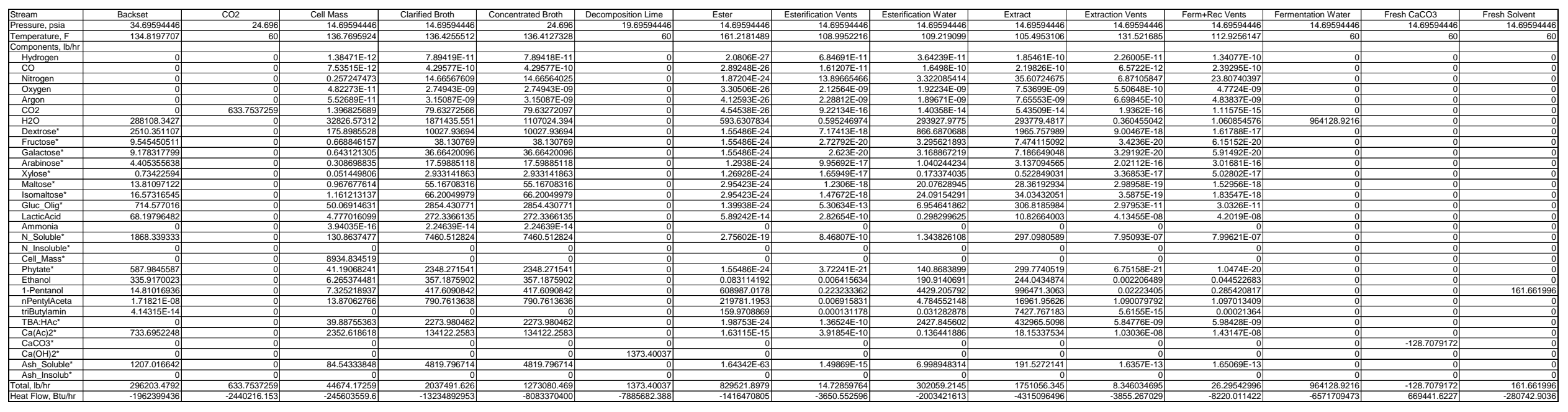

\begin{tabular}{|c|c|c|c|c|c|c|c|c|c|c|c|c|c|c|c|}
\hline 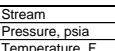 & $\begin{array}{c}\text { Fresh TBA } \\
14.99594446 \\
60\end{array}$ & $\begin{array}{ll}\text { Inert Gas } & 30 \\
& 60 \\
\end{array}$ & $\begin{array}{r}\text { Lean Stripping Gas } \\
14.9695446 \\
172020768\end{array}$ & \begin{tabular}{|l} 
Lean Stripping Gas-rec \\
14.69594446 \\
172.202525
\end{tabular} & $\begin{array}{l}\frac{\text { Light Steep Water }}{14.69599446} \\
12.6\end{array}$ & \begin{tabular}{|l|l|} 
Lime \\
19.69594446 \\
60
\end{tabular} & $\begin{array}{l}\text { Minerals } \\
14.65994446 \\
60\end{array}$ & 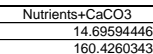 & 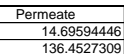 & $\begin{array}{c}\text { Permeate Water } \\
146595444 \\
139.90068\end{array}$ & 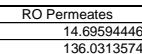 & 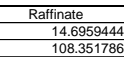 & $\begin{array}{r}\text { Recycle Pentanol } \\
14.69594446 \\
110\end{array}$ & $\begin{array}{r}\text { Recycle Solvent } \\
140.6594446 \\
10992062421 \\
\end{array}$ & \begin{tabular}{r|} 
Recycle TBA \\
14.69594446 \\
110
\end{tabular} \\
\hline \begin{tabular}{|l} 
Temperature, $\mathrm{F}$ \\
Components, lb/hr \\
\end{tabular} & & & 172.0250768 & 172.0252577 & & & & 160.4260343 & & & & 108.351786 & & & \\
\hline \begin{tabular}{|l} 
Hydrogen \\
CO \\
\end{tabular} & & & 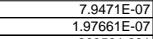 & $\begin{array}{l}7.94473 E-07 \\
1.97238 E-02 \\
\end{array}$ & & & & $\begin{array}{l}7.1 .16828-13 \\
2.19739-12 \\
\end{array}$ & & & & 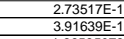 & $\begin{array}{l}1.69877-19 \\
4.040305-20 \\
\end{array}$ & $\begin{array}{l}8.0 .06699-11 \\
3.87253 E-11 \\
\end{array}$ & $\begin{array}{l}4.78634-28 \\
6.650404-27 \\
65027\end{array}$ \\
\hline \begin{tabular}{|l} 
Nitiggen \\
Oxygen \\
\end{tabular} & & $\begin{array}{r}24.40081797 \\
0\end{array}$ & $\begin{array}{l}283591.691 \\
1.813446-05 \\
\end{array}$ & $\begin{array}{l}2835952.004 \\
1.81295 E-05 \\
\end{array}$ & & & & $\frac{0.1268185322}{2.60496-11}$ & & & & 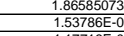 & & $\begin{array}{l}13.838550952 \\
3.48901 E-09 \\
\end{array}$ & $\begin{array}{c}\frac{1.03944-28}{7.60314 E-27} \\
\end{array}$ \\
\hline \begin{tabular}{|l} 
Argon \\
$\mathrm{CO} 22$ \\
\end{tabular} & & & $\begin{array}{l}\frac{2.26792-E-5}{23.6285649} \\
2.549\end{array}$ & 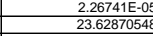 & & & & $2.62956 \mathrm{E}-11$ & & & & $\begin{array}{l}1.177166-0.0 \\
6.94906 E-1 \\
\end{array}$ & & $\begin{array}{l}3.47707 E-09 \\
3.9393 E-14 \\
\end{array}$ & $\begin{array}{l}9.441533-27 \\
1.04565-26 \\
\end{array}$ \\
\hline $\begin{array}{l}\text { H2O } \\
\text { Dextros }\end{array}$ & & & $\begin{array}{r}10754.02876 \\
0\end{array}$ & 10753.99462 & 328725.700 & & & $\begin{array}{l}408955.3439 \\
1734.04799 \\
\end{array}$ & $\begin{array}{r}764411.1569 \\
0\end{array}$ & 284840.945 & $\begin{array}{l}1049252.102 \\
0\end{array}$ & $\begin{array}{l}864046.526 \\
91822255 \\
\end{array}$ & 0.039814795 & $\begin{array}{l}29148.23041 \\
3103817124 \\
\end{array}$ & $\begin{array}{l}0.003380 \\
1038.032\end{array}$ \\
\hline 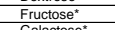 & & & & & $\frac{763.76}{732.76}$ & & & $\begin{array}{l}766.4468526 \\
72.90326\end{array}$ & & & & 34.9147140 & & 0.118021246 & 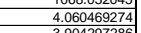 \\
\hline $\begin{array}{l}\text { Cacaaciosex } \\
\text { Arabinoset }\end{array}$ & & & & & $\begin{array}{l}73.485200^{\circ} \\
352.50585 \\
\end{array}$ & & & $\begin{array}{l}73.658 .721275 \\
353.745446 \\
\end{array}$ & & & & 16 & & $\begin{array}{l}0.1133481968 \\
0.031798871 \\
\end{array}$ & $\begin{array}{l}\frac{3.9002992286}{2.065050402} \\
2\end{array}$ \\
\hline Xylose & & & & & 58.750976 & & & $\frac{58.957600743}{3.879906065}$ & & & & $\begin{array}{l}2.76697338 \\
3551787705 \\
\end{array}$ & & & 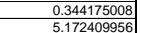 \\
\hline $\begin{array}{l}\text { Isomaltosese } \\
\text { Giluc Oligt }\end{array}$ & & & $=09$ & 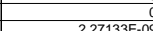 & & & & $\begin{array}{l}4.655887328 \\
.20095283 \\
\end{array}$ & & & & 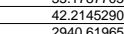 & & $\begin{array}{l}3.735861113 \\
0.013717683\end{array}$ & 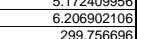 \\
\hline LacticAcid & & & $\begin{array}{l}2.221136-09 \\
0.002352667\end{array}$ & 0.002352697 & 4795 & & & $\begin{array}{r}\frac{20.915093}{5474.527362} \\
\end{array}$ & & & & 2277.6708200 & & $\begin{array}{l}0.101 / 14683 \\
0.001117087 \\
\end{array}$ & $\frac{299.1566)}{10.527220}$ \\
\hline $\begin{array}{l}\text { Ammonia } \\
\text { N_solublet }\end{array}$ & & & $\begin{aligned} 0 \\
0.063296921 \\
\end{aligned}$ & $\frac{0.063297928}{C}$ & $\begin{array}{l}881.2646439 \\
9733.381795 \\
\end{array}$ & & & $\frac{881.2646439}{8854.419165}$ & & & & 8429.83416 & & $\begin{array}{r}0 \\
0.00503544 \\
\end{array}$ & 295.74 \\
\hline $\begin{array}{l}\text { Solublete } \\
\text { Masast }\end{array}$ & & & & & & & & & & & & & & & \\
\hline 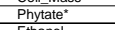 & & & 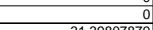 & 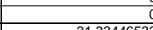 & 1636.634339 & & & 1801.477665 & & & & 2212.81463 & 500 & 2.724654964 & 26904 \\
\hline $\begin{array}{l}\text { Enanotal } \\
\text { 1-Pentanol } \\
\end{array}$ & & & 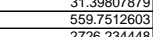 & 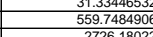 & & & & 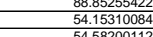 & & & & 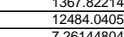 & $\begin{array}{l}102.35696 \\
75521.1956 \\
35219587\end{array}$ & 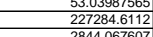 & 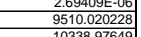 \\
\hline $\begin{array}{l}\text { mentylacea } \\
\text { tributylamin } \\
\end{array}$ & 32.5325100 & & $\begin{array}{r}2720.254448 \\
0\end{array}$ & 2726.18024 & & & & $\frac{54.58000112}{1.06875 E-14}$ & & & & 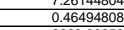 & $\begin{array}{l}378.5148071 \\
159.9085973 \\
\end{array}$ & 2844.067607 & 1038412. \\
\hline 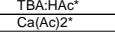 & & & $\begin{array}{r}0.006552077 \\
0\end{array}$ & 0.006552057 & & & & $\begin{array}{l}2313.8618885 \\
189.2603335 \\
\end{array}$ & & & & $\begin{array}{ll}66692.90659 \\
122.006553\end{array}$ & & $\begin{array}{r}1927.8493 \\
0.067767313 \\
\end{array}$ & 17.949 \\
\hline & & & & & & & & 85790.19858 & & & & & & & \\
\hline 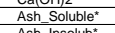 & & 0 & $8.9717 E-09$ & $8.97162 \mathrm{E}-0 \mathrm{SS}$ & 2140.214135 & & 1032.2 & 2477.8854 & & & & 48883.13024 & & 0.026210004 & 184 \\
\hline $\begin{array}{l}\text { Ashinsololubt } \\
\text { all, lohtr }\end{array}$ & 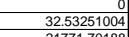 & $\begin{array}{r}24.44081797 \\
\end{array}$ & 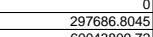 & $\frac{297666.962}{2972}$ & $\frac{349708.192}{3270792}$ & $\frac{2129.98060}{21272072}$ & $\frac{1032.2458}{1.232 .2535}$ & $\frac{520395.0}{328}$ & 764411.1.19 & 288480.9455 & 104925 & $\begin{array}{l}912791.489 \\
92791259\end{array}$ & $\frac{7600146.0248}{7}$ & $\begin{array}{l}261714.796 \\
5174.96\end{array}$ & 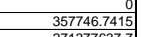 \\
\hline
\end{tabular}


DE-FG36-03GO13010

ZeaChem, Inc.

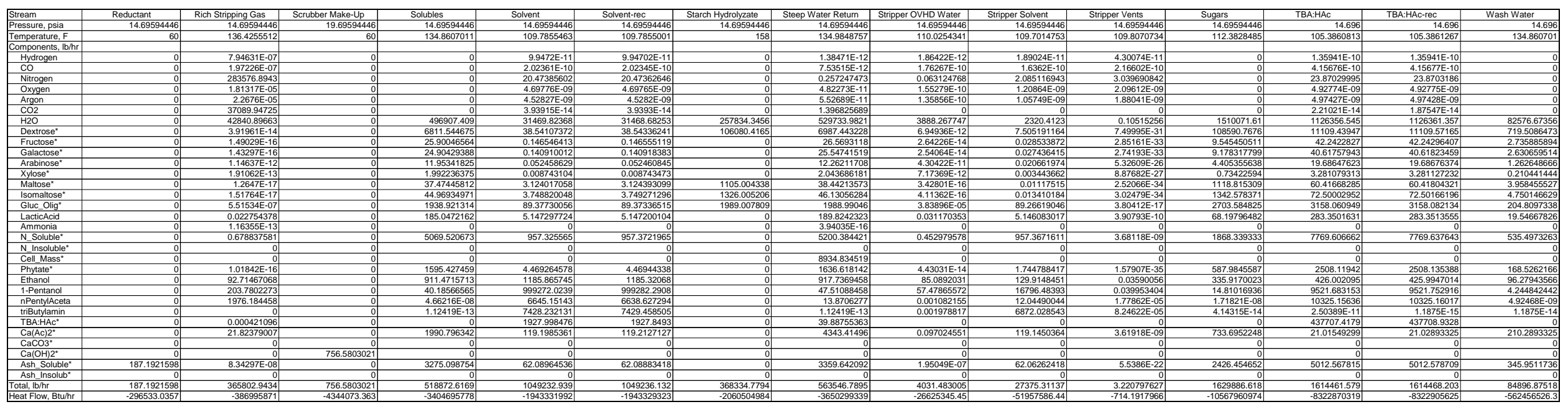

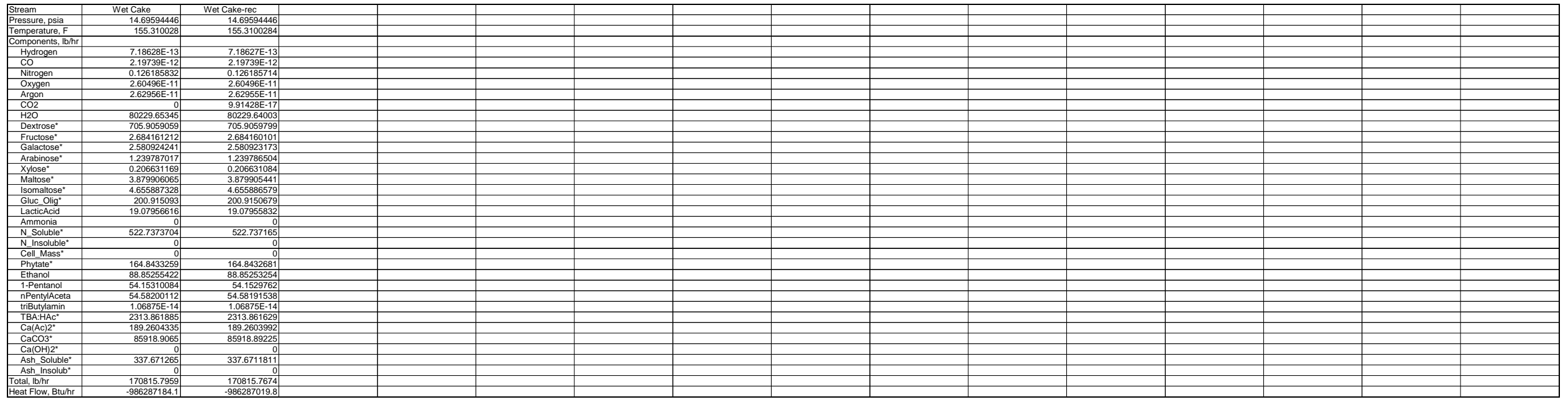




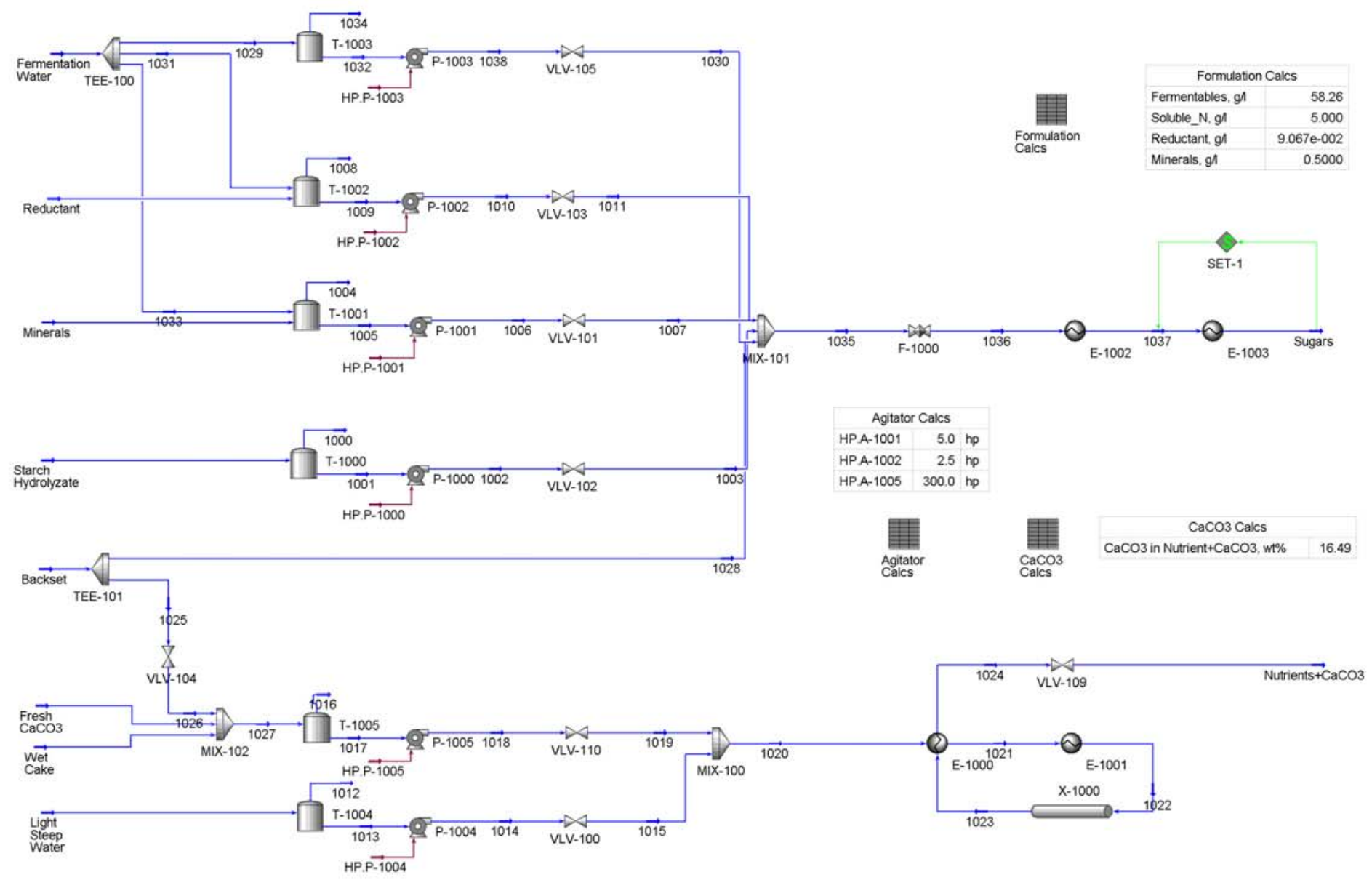


DE-FG36-03G013010

Flowsheet: Feed Prep (FEED)

ZeaChem, Inc.

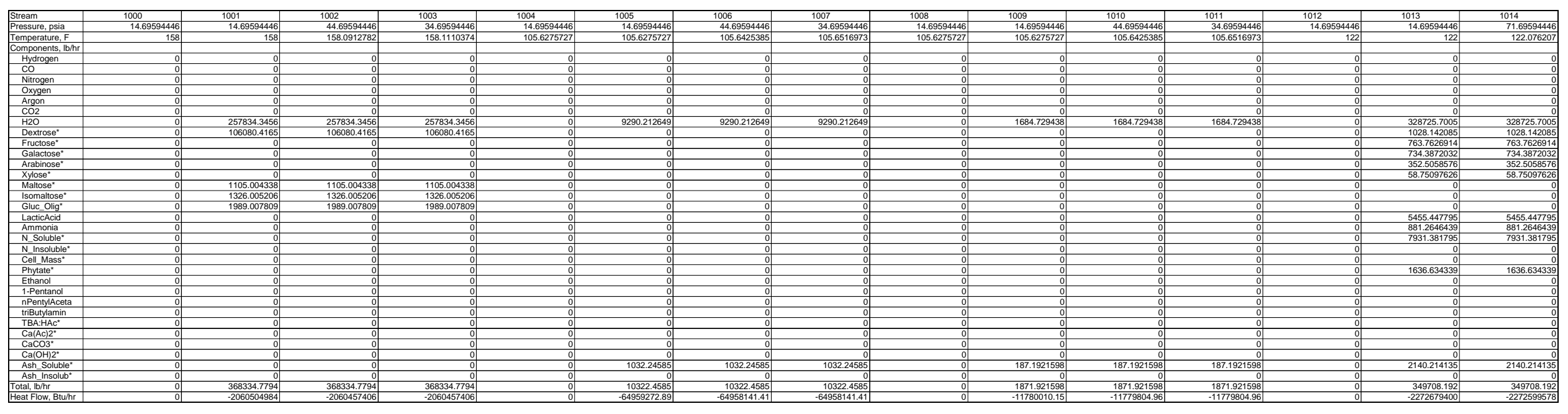

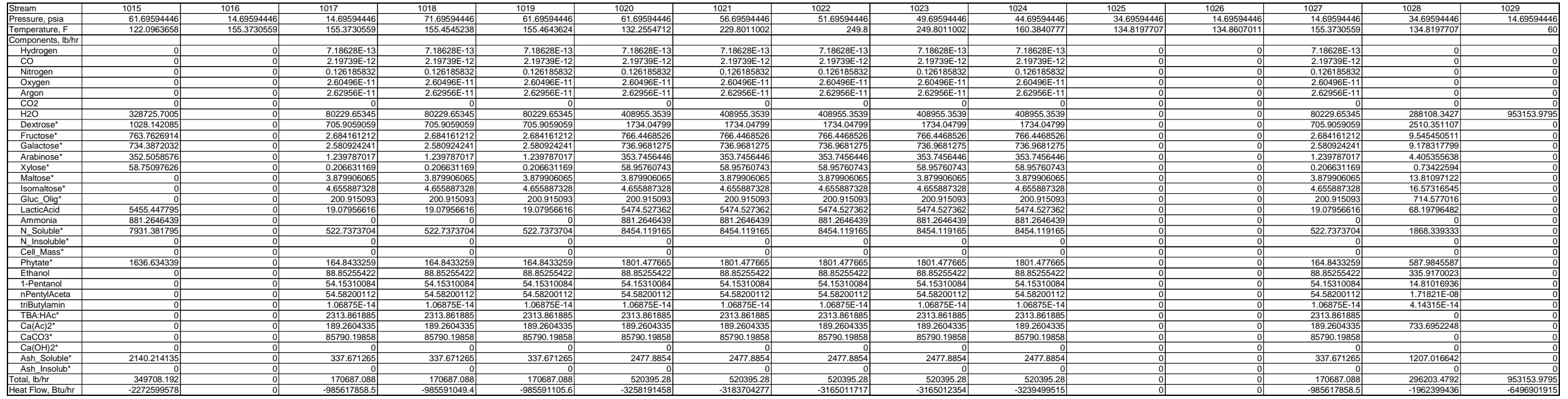


DE-FG36-03GO13010

ZeaChem, Inc.

\begin{tabular}{|c|c|c|c|c|c|c|c|c|c|c|c|c|c|c|c|}
\hline $\begin{array}{l}\text { Stream } \\
\text { Pressure, ssia } \\
\text { Tremperature, } \mathrm{F}\end{array}$ & $\begin{array}{r}\frac{1030}{34.69594446} \\
60.060202006 \\
\end{array}$ & $\begin{aligned} \frac{1031}{14.69594446} \\
60\end{aligned}$ & $\begin{array}{r}\frac{1032}{14.69594446} \\
60\end{array}$ & \begin{tabular}{r|}
$\frac{1033}{14.69594446}$ \\
60
\end{tabular} & \begin{tabular}{l|l|}
1034 \\
14.69594446 \\
60
\end{tabular} & \begin{tabular}{|c|}
1035 \\
34.65954446 \\
94.74245329
\end{tabular} & \begin{tabular}{l|l|}
1036 \\
24.95954466 \\
9.46783929
\end{tabular} & 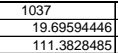 & \begin{tabular}{|c|}
1038 \\
44.6599446 \\
60.039192311 \\
\end{tabular} & \begin{tabular}{|c|} 
Backset \\
34.69594446 \\
134.189707 \\
\end{tabular} & \begin{tabular}{|r|} 
Fermentation Water \\
14.69599446 \\
60
\end{tabular} & $\begin{array}{l}\text { Fresh Caco3 } \\
4.69594446 \\
60\end{array}$ & \begin{tabular}{|l|} 
Light Steep Water \\
14.69599446 \\
122
\end{tabular} & \begin{tabular}{|l|} 
Minerals \\
14.69594446 \\
60
\end{tabular} & $\begin{array}{r}\text { Nutrientst+CaCOC3 } \\
14.65944446 \\
160.4260667 \\
\end{array}$ \\
\hline \begin{tabular}{|c|} 
Components, , lb/hr \\
Hydrogen \\
\end{tabular} & & & & & & & & & & & & & & & $\begin{array}{ll}7.19628 E-13 \\
2.197395-12\end{array}$ \\
\hline \begin{tabular}{|l} 
Nitrogen \\
Oxygen \\
Argon \\
\end{tabular} & & & & & & & & & & & & & & & $\begin{array}{l}\frac{2.19935 E-12}{0.12615832} \\
2.604966-11 \\
2.69256 E-11\end{array}$ \\
\hline \begin{tabular}{|l} 
Argon \\
$\mathrm{CO} 2 \mathrm{O}$ \\
$\mathrm{H} 2 \mathrm{O}$
\end{tabular} & 953153.9795 & 1684.729438 & $\begin{aligned} 953153.9795 \\
0\end{aligned}$ & 9290.212649 & & 1510071.61 & 1510071.61 & 1510071.61 & 953153.9795 & 288108.3427 & 9641128.9216 & & $\frac{0}{328725.7005}$ & & $\begin{array}{l}2.62956-11 \\
408955.3539 \\
4\end{array}$ \\
\hline \begin{tabular}{|l|l|} 
Dextrose $e^{*}$ \\
Fructose \\
\end{tabular} & & & & & & $\begin{array}{l}\frac{108590.7676}{9.545450511} \\
9.75211790\end{array}$ & $\begin{array}{l}108590.7676 \\
9.545450511 \\
9072017709\end{array}$ & $\begin{array}{l}108590.7676 \\
9.544555511 \\
97831779\end{array}$ & & 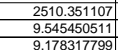 & & & 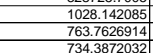 & & 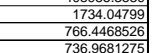 \\
\hline \begin{tabular}{|l} 
Galactosese \\
Arabinose $^{*}$ \\
\end{tabular} & & & & & & $\begin{array}{l}\frac{9.1783777999}{4.405353538} \\
4\end{array}$ & $\begin{array}{l}9.1773377799 \\
4.40535638 \\
\end{array}$ & $\begin{array}{l}\frac{9.1738317799}{4.40335638} \\
\end{array}$ & & 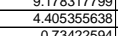 & & & 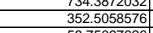 & & 736..968 \\
\hline \begin{tabular}{|l|l|} 
yolose \\
Maltose $^{x}$ \\
\end{tabular} & & & & & & $\mid \begin{array}{l}0.7134225944 \\
1118.81509 \\
\end{array}$ & 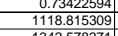 & $\begin{array}{r}0.743252594 \\
1118.815309 \\
\end{array}$ & & $\begin{array}{c}0.743252594 \\
13.81097122 \\
\end{array}$ & & & $\begin{aligned} 58.75097626 \\
\end{aligned}$ & & 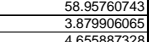 \\
\hline 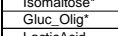 & & & & & & 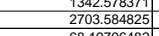 &  & 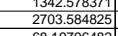 & & 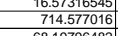 & & & & & $\begin{array}{l}4.655887328 \\
200.915093 \\
544527262\end{array}$ \\
\hline \begin{tabular}{|l} 
Lacichaccid \\
Ammonia \\
\end{tabular} & & & & & & $\begin{array}{l}68.19796482 \\
\end{array}$ & 68.19796482 & 68.19796482 & & 68.19796482 & & & $\begin{array}{l}\frac{5555.4477795}{881.2646439} \\
8\end{array}$ & & 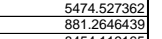 \\
\hline 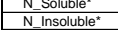 & & & & & & $\begin{array}{r}1868.339333 \\
0\end{array}$ & $\begin{array}{rl}1868.3393333 & \mathrm{o} \\
\end{array}$ & $\begin{array}{rl}1868.339333 & 0 \\
\end{array}$ & & $\begin{array}{rl}1868.339333 & 0 \\
\end{array}$ & & & 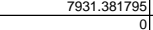 & & $\begin{array}{rl}8454.119165 & 0 \\
\end{array}$ \\
\hline \begin{tabular}{|l|} 
Cell_masss \\
Phytate $^{*}$
\end{tabular} & & & & & & \begin{tabular}{r|}
587.9845587 \\
\end{tabular} & \begin{tabular}{r|}
587.9845587 \\
\end{tabular} & \begin{tabular}{r|}
587.9845587 \\
5
\end{tabular} & & \begin{tabular}{r|}
587.9845587 \\
\end{tabular} & & & \begin{tabular}{r|}
1636.6343399 \\
1
\end{tabular} & & 1801.477665 \\
\hline \begin{tabular}{|l|} 
Ethanol \\
1-Pentanol
\end{tabular} & & & & & & $\begin{array}{l}335.9170023 \\
141010963\end{array}$ & \begin{tabular}{|c|c|}
335.9170023 \\
1481016936
\end{tabular} & $\begin{array}{l}335.9170023 \\
1481016936 \\
\end{array}$ & & \begin{tabular}{|c|c|}
335.9170023 \\
1481019636
\end{tabular} & & & 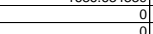 & & \\
\hline \begin{tabular}{|c|} 
nPenty/Aceta \\
triButlamin
\end{tabular} & & & & & & 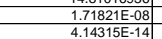 & \begin{tabular}{|c|c|}
$1.718211-08$ \\
$4.44315-14$ \\
\end{tabular} & $\begin{array}{l}1.71821 E-08 \\
4.13315-14\end{array}$ & & 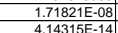 & & & $\frac{0}{0}$ & & $\begin{array}{l}\frac{54.552000112}{1.068756-14} \\
\end{array}$ \\
\hline 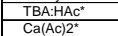 & & & & & & \begin{tabular}{r|} 
\\
733.6952248
\end{tabular} & \begin{tabular}{r|}
733.6952248 \\
7
\end{tabular} & \begin{tabular}{r|} 
\\
733.6952248
\end{tabular} & & 733.6952248 & & & & & 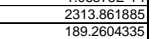 \\
\hline 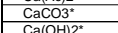 & & & & & & & & & & & & $\begin{array}{l}-128.7079172 \\
-1\end{array}$ & & & 85790.19858 \\
\hline 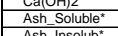 & & & & & & 2426.454452 & 2426.454652 & 2426.454652 & & 1207.01642 & & & 2140.214135 & 1032.24585 & A $477.88^{2}$ \\
\hline 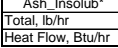 & $\begin{array}{l}\frac{953153.9795}{-6496790503} \\
-\frac{1}{-6}\end{array}$ & $\begin{array}{r}-1684.729438 \\
-11483477.12 \\
\end{array}$ & $\begin{array}{l}\frac{9535353.9795}{6-6496901915} \\
\end{array}$ & $\begin{array}{l}9290.212649 \\
-63324081.56 \\
\end{array}$ & & $\begin{array}{r}16298866.618 \\
10596385292 \\
\end{array}$ &  & $\begin{array}{r}\frac{1629886.618}{-10569580124} \\
-10\end{array}$ & \begin{tabular}{r|}
953153.9795 \\
-6496790503
\end{tabular} & $\begin{array}{l}296203.4792 \\
-1962399436 \\
\end{array}$ & 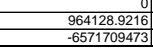 & $\begin{array}{l}-\frac{-128.7079172}{669441.6227} \\
6\end{array}$ & $\begin{array}{r}349708.192 \\
-2272679400 \\
\end{array}$ & $\begin{array}{r}1032.2450 \\
1635191.323 \\
\end{array}$ & $\begin{array}{r}5203955.28 \\
-323949538 \\
\end{array}$ \\
\hline
\end{tabular}

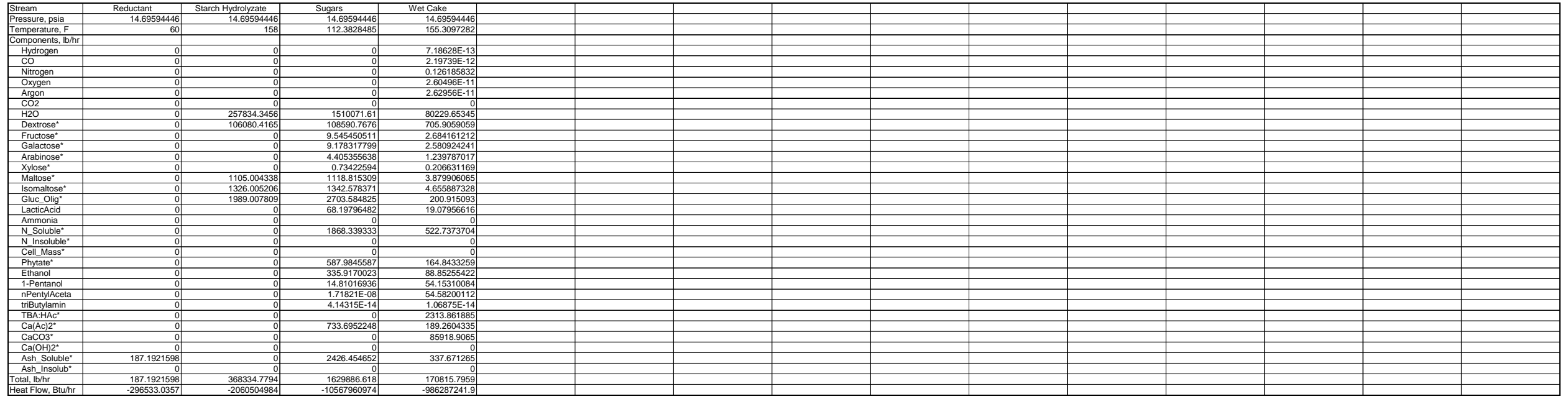


DE-FG36-03G013010

ZeaChem, Inc.

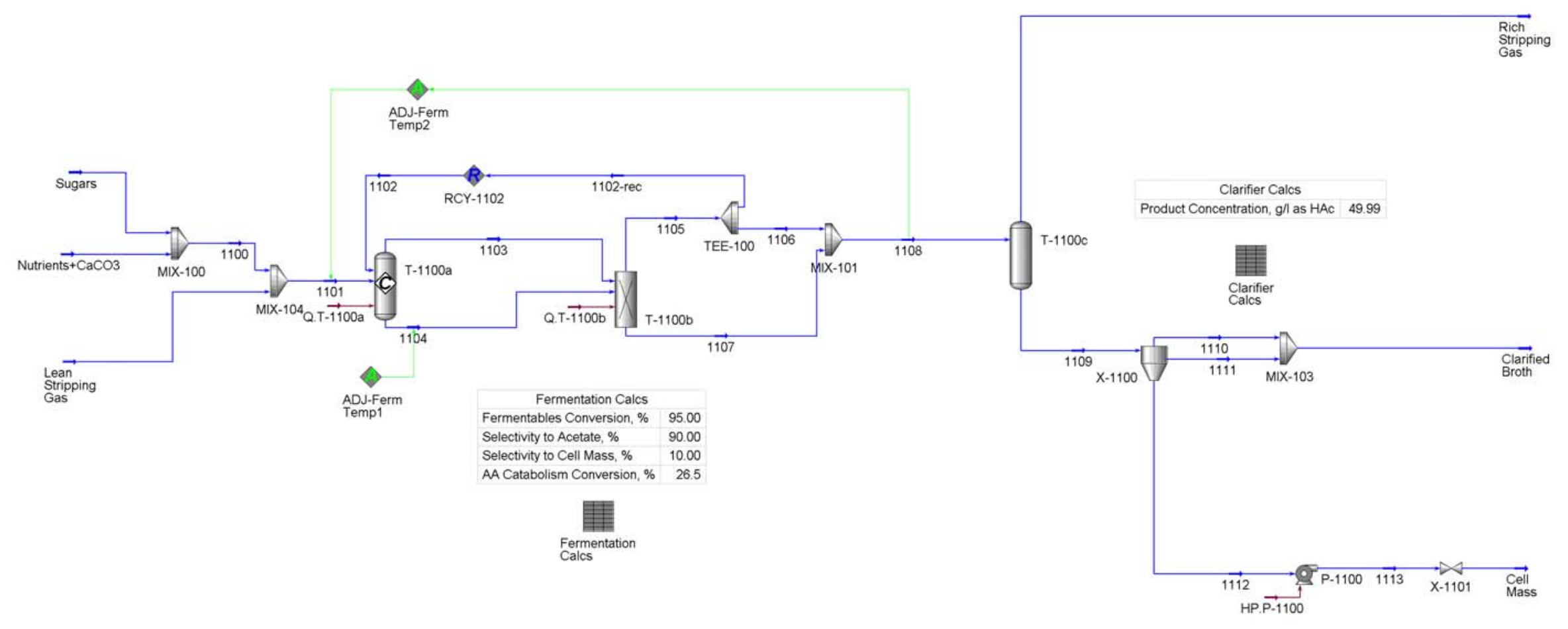


DE-FG36-03G013010

Flowsheet: Fermentation (FERM)

ZeaChem, Inc.

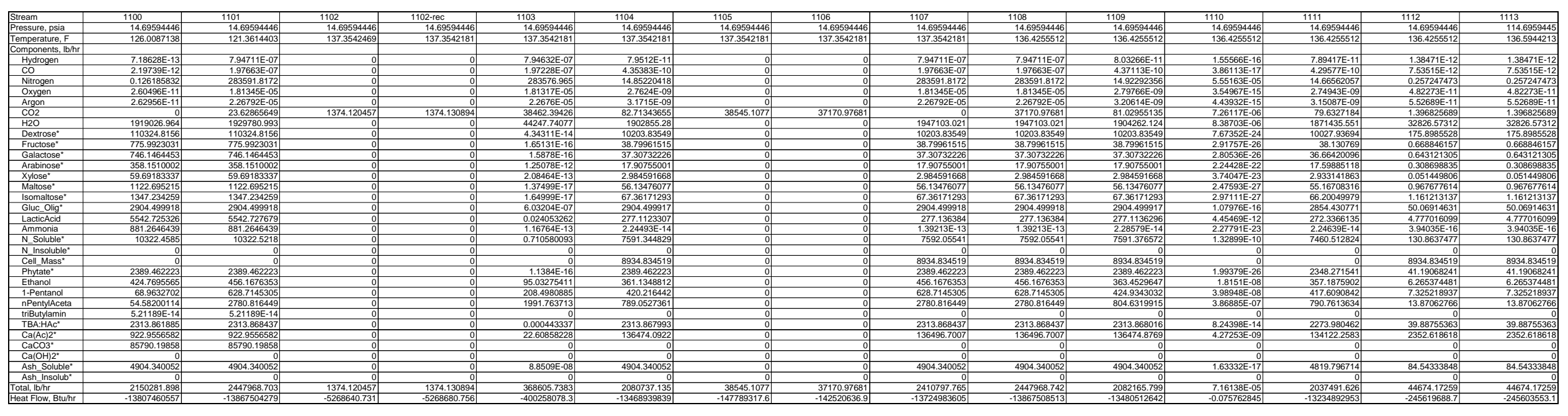

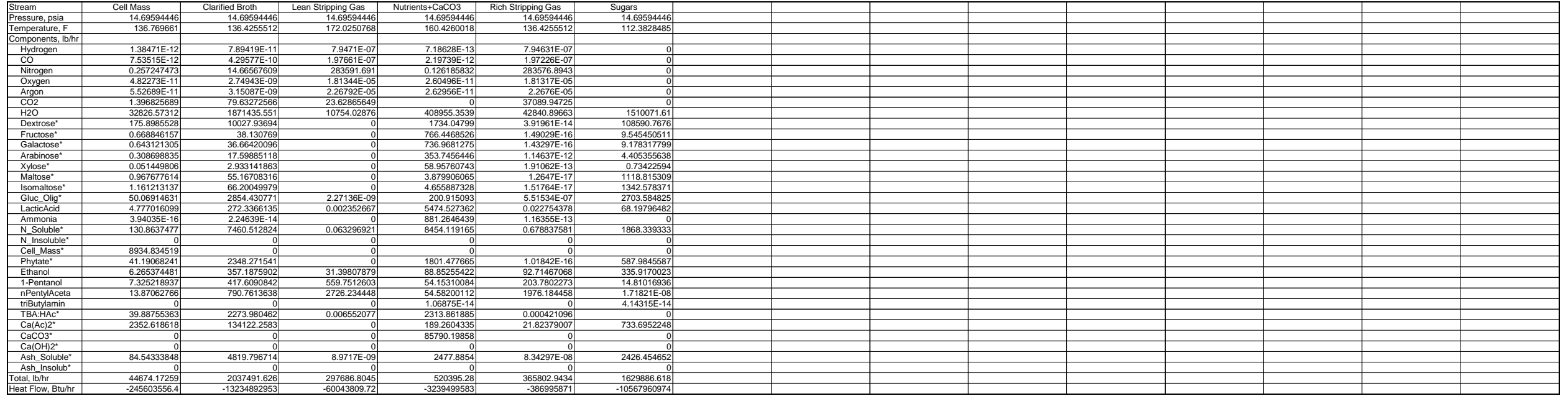




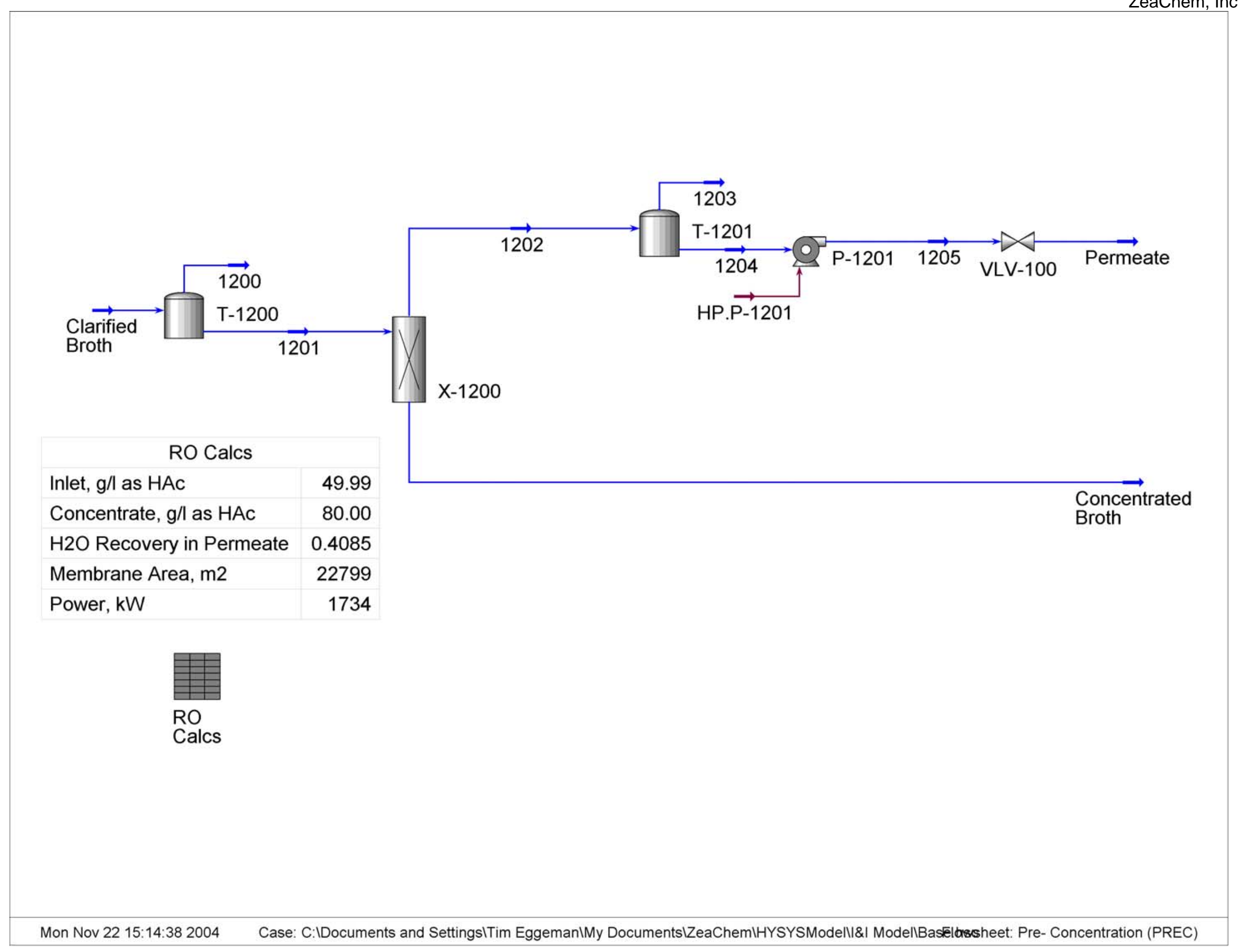


DE-FG36-03G013010

ZeaChem, Inc.

Flowsheet: Pre-Concentration (PREC)

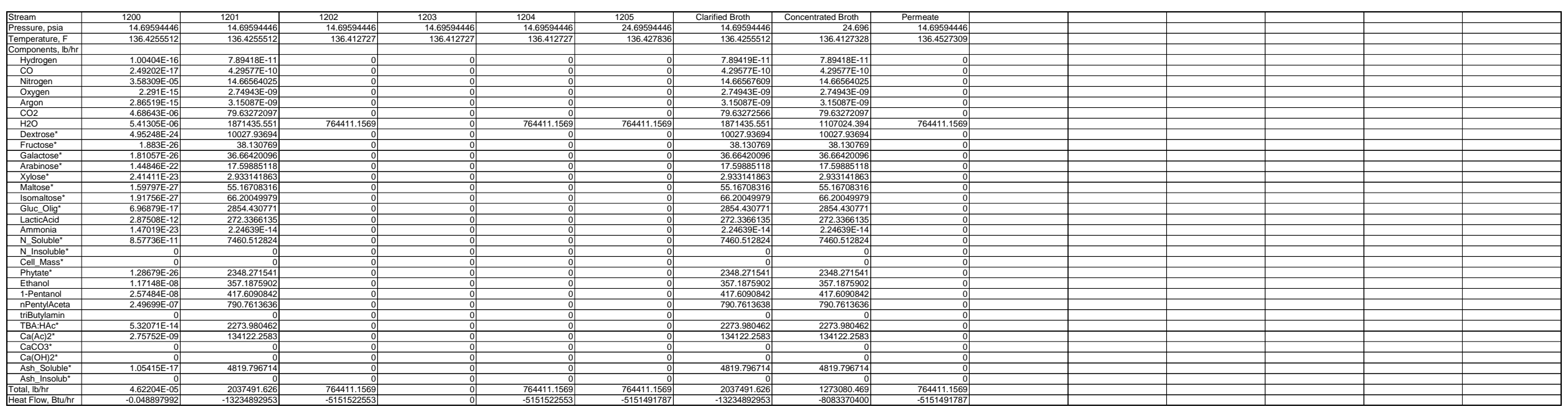


DE-FG36-03G013010

ZeaChem, Inc.

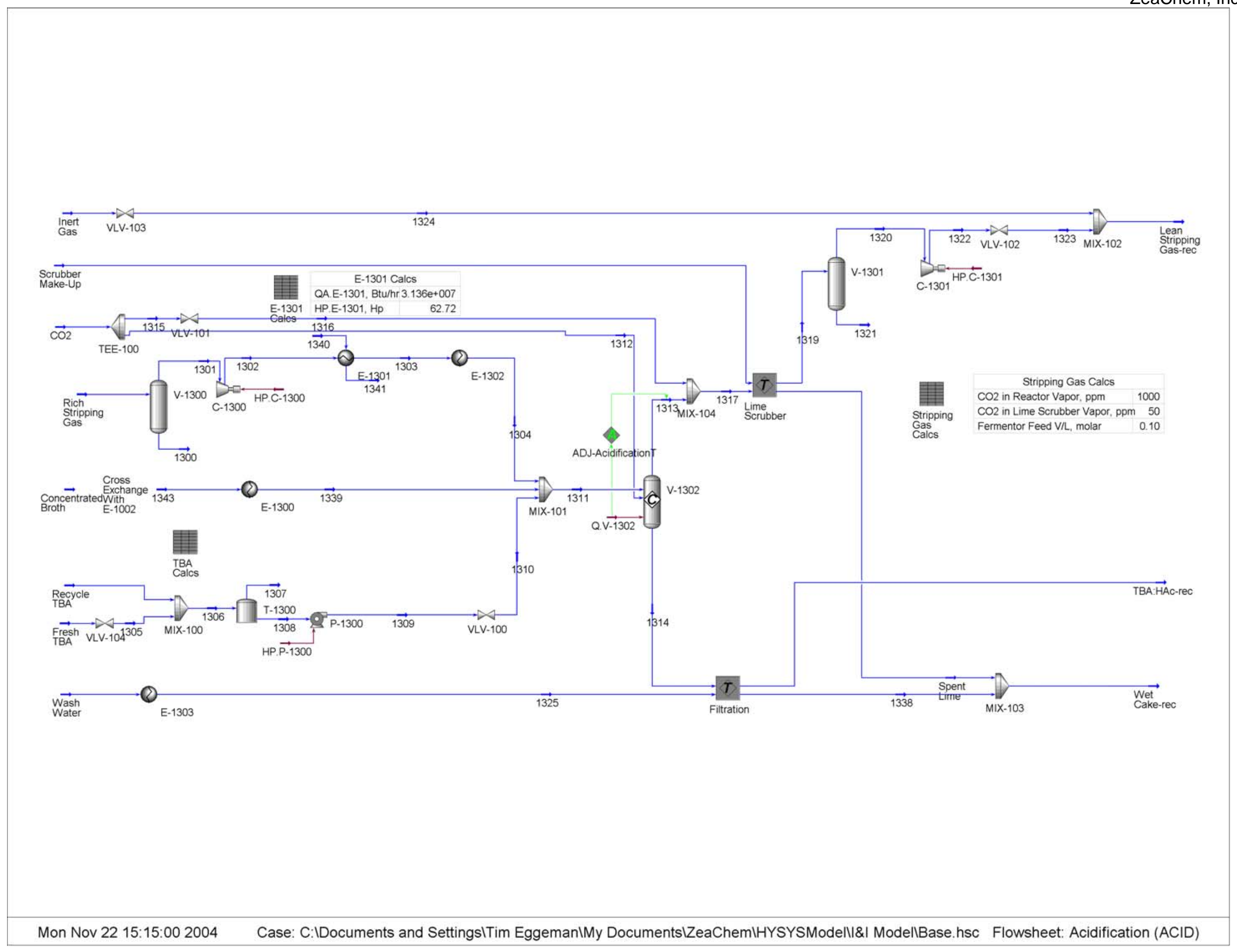


DE-FG36-03G013010

Flowsheet: Acidification (ACID)

ZeaChem, Inc.

\begin{tabular}{|c|c|c|c|c|c|c|c|c|c|c|c|c|c|c|c|}
\hline $\begin{array}{l}\text { Stream } \\
\text { Pressure, psia }\end{array}$ & $\begin{array}{l}1300 \\
14.69594446\end{array}$ & $\frac{1301}{14.695944466}$ & $\begin{array}{r}1302 \quad 26.696 \\
\end{array}$ & $\begin{array}{l}1303 \quad 25.690 \\
\end{array}$ & $1304 \quad 24.696$ & $\frac{1305}{14.69594446}$ & $\begin{array}{l}1306 \\
14.69594446\end{array}$ & $\begin{array}{l}\frac{1307}{14.69594446} \\
\end{array}$ & $\frac{1308}{14.69594446}$ & $\begin{array}{ll}1309 \\
34.696 \\
\end{array}$ & $\begin{array}{ll}1310 & \\
& 24.696 \\
\end{array}$ & $\begin{array}{l}1311 \\
24.696\end{array}$ & $\begin{array}{l}1312 \quad 24.696 \\
\end{array}$ & $1313 \quad 19.696$ & $\begin{array}{ll}1314 & 19.696\end{array}$ \\
\hline 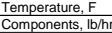 & & & & & & & & & & & & & & & \\
\hline \begin{tabular}{|l|l|l|l} 
Hydrogen \\
Co
\end{tabular} & & \begin{tabular}{|l|l|}
$7.9431 E-07$ \\
$1.972265-07$
\end{tabular} & \begin{tabular}{|c|}
$7.946316-07$ \\
$1.1972626-07$
\end{tabular} & $\begin{array}{l}7.94631 E-07 \\
1.972626=0.7\end{array}$ & $\begin{array}{l}7.946311-07 \\
19726-07\end{array}$ & & $\begin{array}{l}\frac{4.78634 E-28}{6} \\
6.56440-27\end{array}$ & & & & & $\begin{array}{l}7.94711-07 \\
19756-07\end{array}$ & & 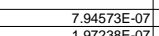 & $\begin{array}{l}1.3666 \mathrm{E}-1 \\
1.778 \mathrm{E}\end{array}$ \\
\hline \begin{tabular}{|l|} 
Nitrogen \\
Oxxygen
\end{tabular} & & $\begin{array}{l}283576.8943 \\
28.817177-05\end{array}$ & $\frac{283576.8943}{2.8131717-05}$ & 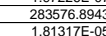 & $\frac{283576.8943}{288513717-05}$ & & 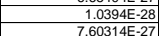 & & & & & $\begin{array}{l}2835991.55999 \\
1.81444-05\end{array}$ & & 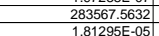 & $\begin{aligned} \frac{23.99650432}{4} \\
493585-09\end{aligned}$ \\
\hline & & \begin{tabular}{c|c|c|c|c|}
$2.2676-05$ \\
2
\end{tabular} & $2.2676 \mathrm{E}-05$ & $2.2676 \mathrm{E}-0.5$ & $2.2676 \mathrm{E}-0.0$ & & $9.49153 \mathrm{E}-27$ & & & & & & 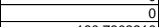 & 2.26741E-C & \\
\hline Dextrose $e^{*}$ & & $\begin{array}{l}3.91961 E-14 \\
1029-5\end{array}$ & $3.91961 \mathrm{E}-14$ & $\begin{array}{l}3.91961 E-14 \\
100205-14\end{array}$ & $\begin{array}{l}3.91961 \mathrm{E}-14 \\
190205-14\end{array}$ & & 1068.032045 & & $\begin{array}{l}1068.032045 \\
0602620\end{array}$ & $\begin{array}{l}1068.032045 \\
\end{array}$ & 1068.032045 & 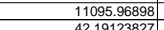 & & $\frac{1.04716 E-1 \mid}{30.915[-1}$ & $\begin{array}{l}11095.9689 \\
12019238\end{array}$ \\
\hline & & & & $\begin{array}{l}1.490929 E-16 \\
1.43297-16\end{array}$ & $\begin{array}{l}1.49029 E-1 \\
1.43297 E-1\end{array}$ & & $\begin{array}{l}\frac{3.060469274}{3.90429728} \\
\end{array}$ & & $\begin{array}{r}4.0664692974 \\
3.904297286\end{array}$ & $\begin{array}{r}4.060469274 \\
3.904297286\end{array}$ & $\begin{array}{l}\frac{4.060469274}{3.904297286} \\
\end{array}$ & 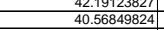 & & $3.9811 E-11$ & $\frac{42.191238}{40.568498}$ \\
\hline & & 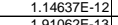 & 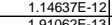 & 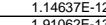 & 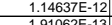 & & $\begin{array}{l}2.06505050202 \\
2\end{array}$ & & 20.0650504020 & 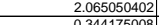 & 5050402 & 66390156 & & 8261E. & \\
\hline & & $1.2647 \sqrt{1}$ & & & $1.2647 \mathrm{E}-1$ & & 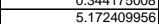 & & & & & & & & \\
\hline & & $1.51764-11$ & $1.51764-17$ & $1.51764 E-12$ & $1.51764 \mathrm{E}-$ & & 6.206902106 & & 6.206902106 & 6.206902106 & 6902106 & 4074019 & & & \\
\hline $\begin{array}{l}\text { Gluc Olilot } \\
\text { LacticAcid }\end{array}$ & & 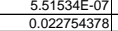 & $\frac{5.515254 \mathrm{E}-07}{0.02275438}$ & $\begin{array}{l}5.51534 E-07 \\
0.0227543776\end{array}$ & $\begin{array}{l}5.5153344-0 \\
0.02275437 \\
0.5\end{array}$ & & $\begin{array}{r}299.9566966 \\
10.57222031\end{array}$ & & \begin{tabular}{|r|}
299.756696 \\
10.52722031
\end{tabular} & $\begin{array}{r}299.9566966 \\
10.57222031\end{array}$ & \begin{tabular}{|c|}
299.756696 \\
10.57222031
\end{tabular} & $\begin{array}{l}3154.187467 \\
288.288582\end{array}$ & & 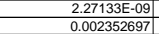 & $\begin{array}{l}3154.1874 \\
288.88423 \\
\end{array}$ \\
\hline 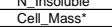 & & & & & 0 & & 0 & & & 0 & 0 & 0 & & & \\
\hline Phyyate $^{*}$ & & $\begin{array}{l}c_{1.218142-16}^{92.1467068} \\
\end{array}$ & 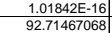 & 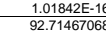 & 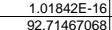 & & $\frac{156.1808986}{2.69409 E-06}$ & & 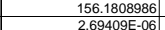 & $\frac{156.1808986}{2.69096-06}$ & $\frac{156.1808986}{2.69090-06}$ & 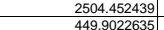 & & $\frac{1.84118 E-18}{3132434552}$ & 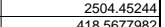 \\
\hline $\begin{array}{l}\text { Emanolanol } \\
1 \text { - Pentanonol }\end{array}$ & & 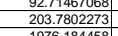 & 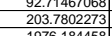 & 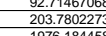 & 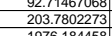 & & 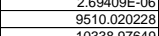 & & 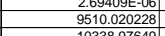 & 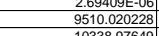 & 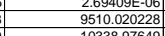 & 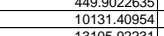 & & 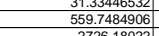 & 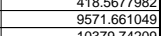 \\
\hline 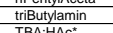 & & 0 & 0 & 20 & 0 & 32.53251004 & 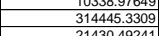 & & 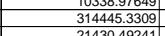 & 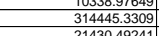 & 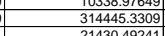 & 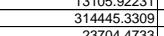 & & $\begin{array}{r}2726.18022 \\
0\end{array}$ & 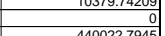 \\
\hline & & 21.82379007 & $\begin{array}{l}2.01 .82379007 \\
\end{array}$ & 2 & $\begin{array}{l}21.82379007 \\
2\end{array}$ & & $\begin{array}{l}1150.45251 \\
17.94925201\end{array}$ & & $\begin{array}{l}245.949425201 \\
17.94952\end{array}$ & $\begin{array}{l}21450494251 \\
17.94925201\end{array}$ & $\begin{array}{l}2145044242 \\
17.94925201\end{array}$ & 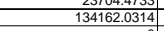 & & & \\
\hline (1) ${ }^{2 *}$ & & & & & & & & & & & & & & & 96.8751 \\
\hline Solublet & & $8.34297 \mathrm{E}-08$ & $8.34297 \mathrm{E}-08$ & $8.34297 \mathrm{E}-0 \mathrm{E}$ & $8.34297 \mathrm{E}-08$ & & 184.5020024 & & 184.5020024 & 184.5020024 & 20024 & 5004.298716 & & $8.97162 \mathrm{E}-09$ & 5 \\
\hline 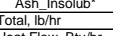 & & 365802.9434 & 365502.9434 & $\frac{365802.9434}{3650}$ & 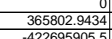 & $\begin{array}{r}32.53251004 \\
2.7271702\end{array}$ & 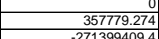 & & $\begin{array}{r}357779.274 \\
27120909\end{array}$ & $\begin{array}{r}0 \\
357779.274 \\
0236265\end{array}$ & $\begin{array}{r}0 \\
357779.274 \\
-27136266\end{array}$ & \begin{tabular}{r|}
1996662.687 \\
981225892
\end{tabular} & $\frac{160.7302210}{16.16}$ & 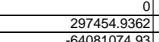 & 9365.078 \\
\hline
\end{tabular}

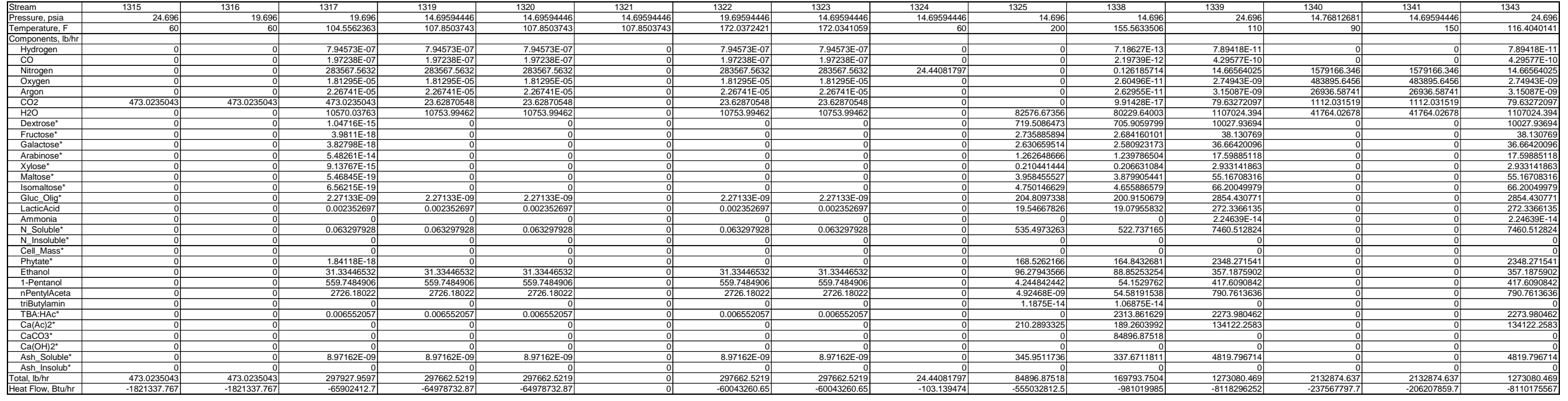


DE-FG36-03G013010

ZeaChem, Inc.

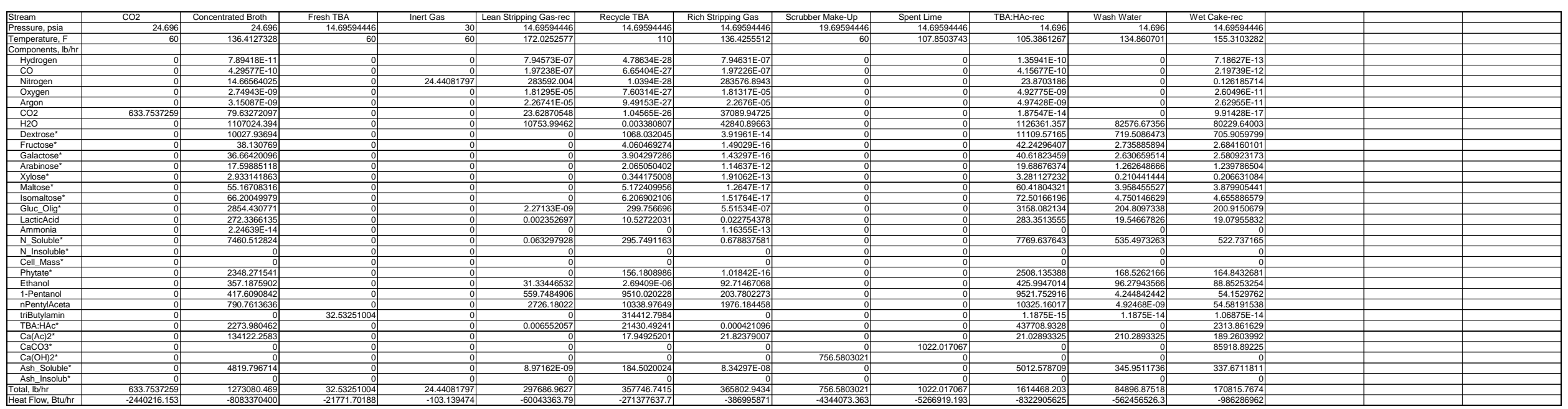



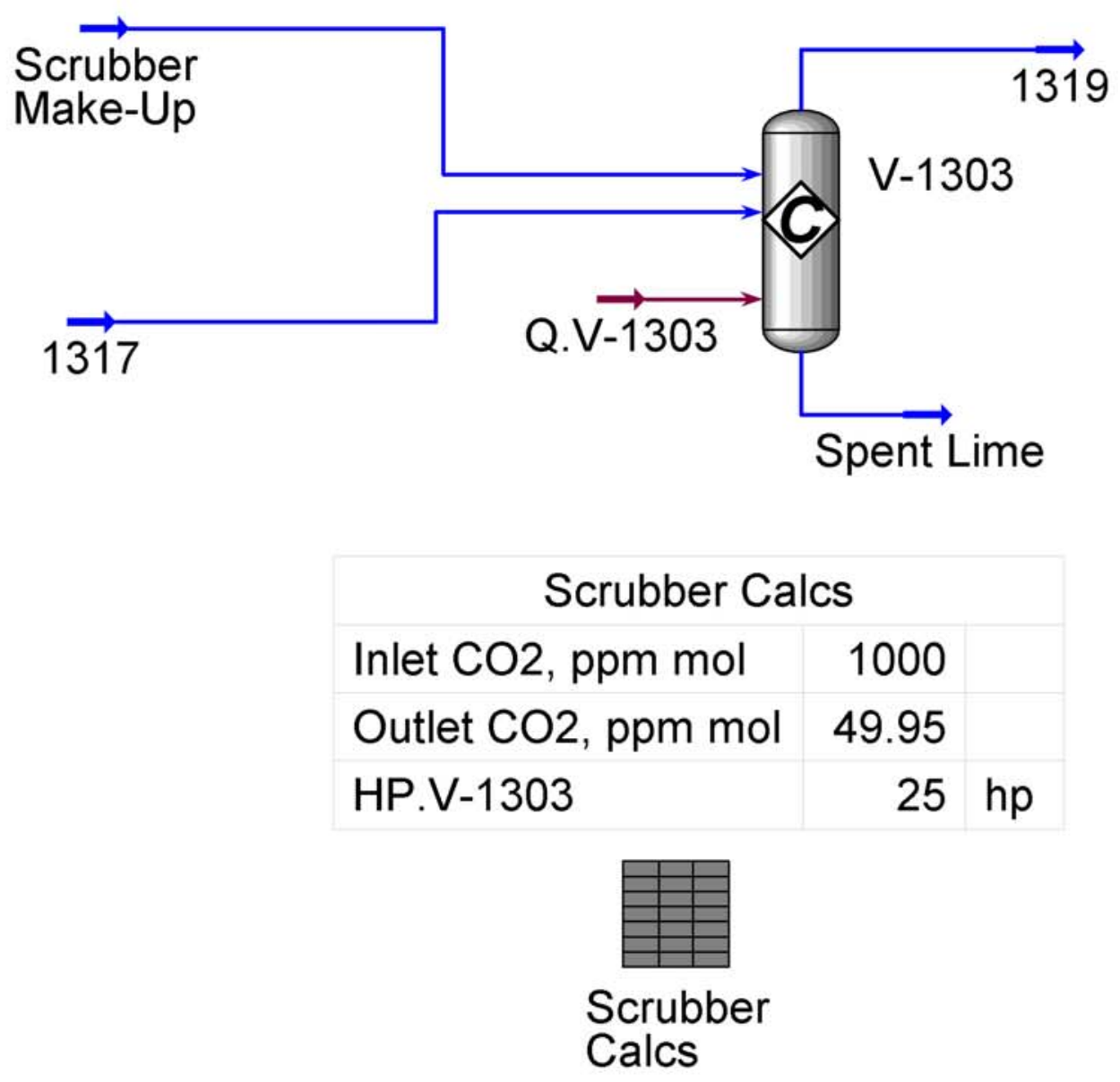
DE-FG36-03G013010

ZeaChem, Inc.

Flowsheet: Lime Scrubber (SCRB)

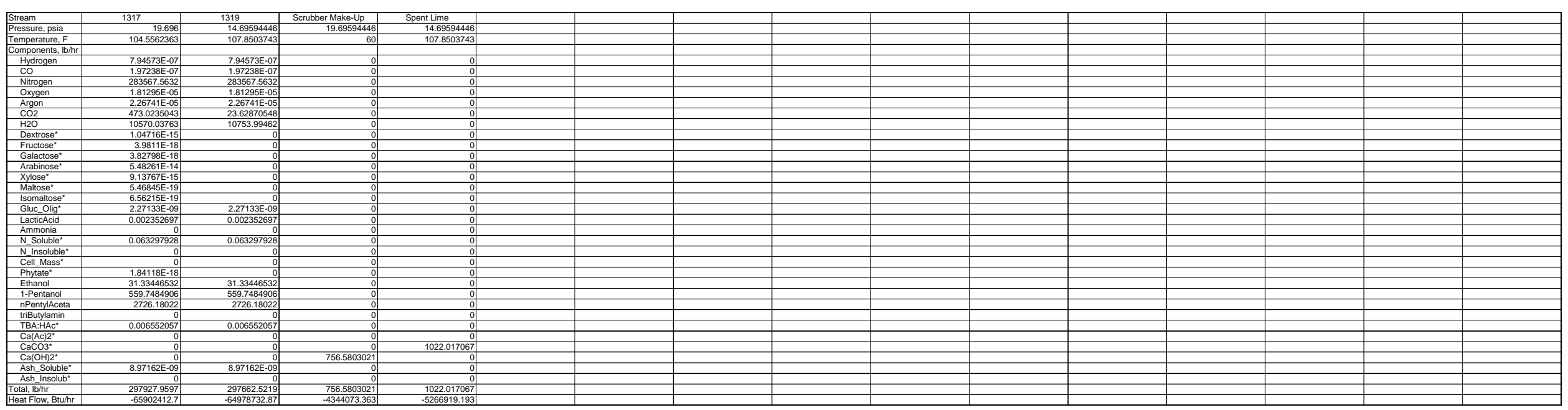




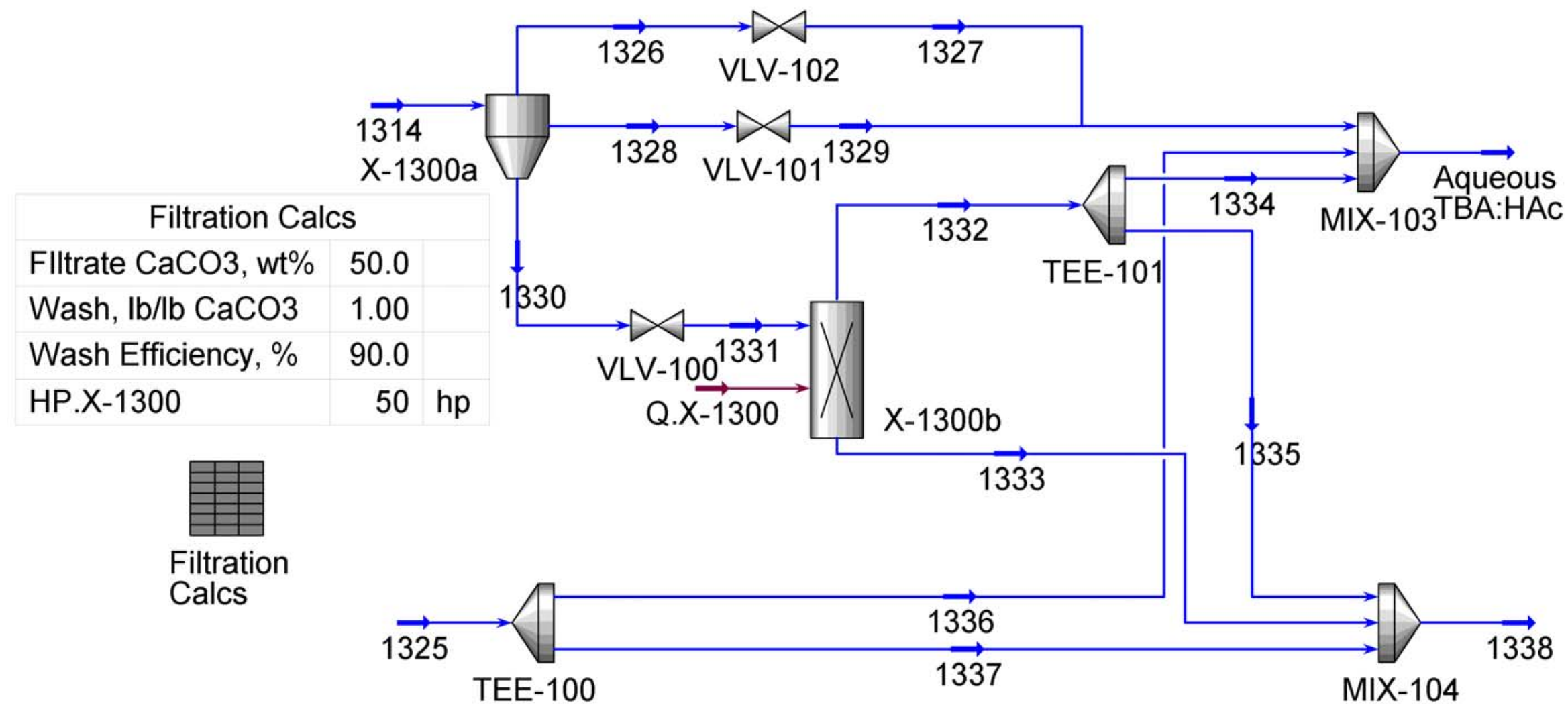


DE-FG36-03G013010

Flowsheet: Filtration (FILT)

ZeaChem, Inc.

\begin{tabular}{|c|c|c|c|c|c|c|c|c|c|c|c|c|c|c|c|}
\hline 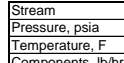 & $\begin{array}{r}1314 \quad 19.696 \\
104.135358 \\
\end{array}$ & $\begin{array}{ll}132509 \\
& 130 \\
\end{array}$ & $\begin{aligned} 1326 \\
104.6135356 \\
\end{aligned}$ & \begin{tabular}{|c|}
1327 \\
104.62351096 \\
\end{tabular} & \begin{tabular}{r|}
1328 \\
104.6196565 \\
\end{tabular} & \begin{tabular}{r|r|}
1329 \\
104.62429393 \\
\end{tabular} & \begin{tabular}{r|r|}
$1330 \quad$ \\
104.69656 \\
\end{tabular} & \begin{tabular}{|r|}
$1331 \quad 14.696$ \\
104.618221 \\
\end{tabular} & \begin{tabular}{r|}
$1332 \quad$ \\
104.696 \\
104618221 \\
\end{tabular} & $\begin{array}{r}1333 \quad 14.69 \\
104.61822 \\
\end{array}$ & \begin{tabular}{|r|}
$1334 \quad 14.696$ \\
104.618221 \\
\end{tabular} & $\begin{array}{r}1335 \quad 14.69 \\
104.61822 \\
\end{array}$ & $\begin{array}{|rr|}1336 & 14.696 \\
200 \\
\end{array}$ & $\begin{array}{ll}337 & \\
& 14.696 \\
2\end{array}$ & \begin{tabular}{|l|}
1338 \\
155.56366552 \\
\end{tabular} \\
\hline $\begin{array}{l}\text { Hydrogen } \\
\text { co }\end{array}$ & $\begin{array}{l}\frac{1.3666-10}{4.18747-10} \\
\end{array}$ & & & & $\begin{array}{r}1.29474 \mathrm{E}-10 \\
3.959 \mathrm{E}-10\end{array}$ & $\begin{array}{l}1.29474 E-10 \\
\frac{3.959-10}{10}\end{array}$ & $\begin{array}{l}7.18627 \mathrm{E}-12 \\
.19739 \mathrm{E}-11\end{array}$ & $\begin{array}{l}7.18627 \mathrm{E}-12 \\
2.19739 \mathrm{E}-11\end{array}$ & $\frac{7.18627 \mathrm{E}-12}{2.19739 \mathrm{E}-11}$ & & $\begin{array}{l}\frac{6.46746-12}{1.97756-511} \\
\end{array}$ & $\begin{array}{l}7.18627 \mathrm{E}-1 \\
2.19739 \mathrm{E}-1\end{array}$ & & & $\begin{array}{l}7.18627 \mathrm{E}-13 \\
2.19739 \mathrm{E}-12 \\
\end{array}$ \\
\hline $\begin{array}{l}\text { Nitrogen } \\
\text { Oxygen }\end{array}$ & $\begin{array}{l}23.99560432 \\
.95385-09 \\
\end{array}$ & & & & $\begin{array}{l}22.736464717 \\
4.6933-09 \\
\end{array}$ & $\begin{array}{l}22.736464717 \\
.6933 E-09 \\
\end{array}$ & $\frac{1.261857142}{2.60496 E-10}$ & $\frac{1.261855142}{2.60496 \mathrm{E}-10}$ & $\frac{1.261857142}{2.60496 E-10}$ & & $\frac{1.135671427}{2.34446 E-10}$ & $\frac{0.12618571}{2.60496 E-1}$ & & & $\begin{array}{c}0.126185574 \\
2.60496 E-11\end{array}$ \\
\hline $\begin{array}{lll}\text { Argon } \\
\text { CO22 }\end{array}$ & $\frac{5.00055 E-09}{1.88538 E-14}$ & & & & $\begin{array}{l}4.73762 E-09 \\
1.78624-14 \\
\end{array}$ & $\begin{array}{l}4.73762 E-09 \\
1.78624-14\end{array}$ & $\begin{array}{l}\frac{2.62955-10}{9.91428-16} \\
\end{array}$ & $\begin{array}{l}2.69255-10 \\
9.91428-16 \\
\end{array}$ & $\begin{array}{l}2.62955 E-10 \\
9.91428 E-16 \\
\end{array}$ & & $\begin{array}{l}\frac{2.36366-10}{8.92285 E-16} \\
\end{array}$ & $\begin{array}{l}2.62955 E-1 \\
9.91428 E-1 \\
\end{array}$ & & & $\begin{array}{l}.62955 \mathrm{E}-11 \\
9.91428 \mathrm{E}-17\end{array}$ \\
\hline trose $\mathrm{e}^{*}$ & $\begin{array}{l}1124410.424 \\
11095.96899 \\
\end{array}$ & 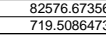 & & & $\begin{array}{l}10699907.986 \\
10512.48701 \\
\end{array}$ & $\begin{array}{l}10694907.986 \\
10512.48701 \\
\end{array}$ & $\begin{array}{l}55106.38328 \\
583.481974 \\
\end{array}$ & $\begin{array}{r}551066.38828 \\
583.41974 \\
\end{array}$ & $\begin{array}{r}51063.38328 \\
583.481974 \\
\end{array}$ & & $\begin{array}{l}55135.7 .74446 \\
525.133766 \\
\end{array}$ & $\begin{array}{l}5910.633828 \\
58.348197\end{array}$ & $\begin{array}{l}8257.667756 \\
71.95086473 \\
\end{array}$ & $\begin{aligned} 74319.0062 \\
647.5777825 \\
\end{aligned}$ & 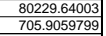 \\
\hline 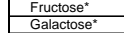 & $\begin{array}{r}42.2191232388 \\
40.56849825 \\
\end{array}$ & \begin{tabular}{|l}
2.7338858989 \\
2.63059514 \\
\end{tabular} & & & $\begin{array}{l}39.97261032 \\
38.43520214 \\
\end{array}$ & $\begin{array}{l}3.9 .976261032 \\
38.43520214 \\
\end{array}$ & $\begin{array}{l}2.2 .28627957 \\
2.133296107 \\
\end{array}$ & $\begin{array}{l}\frac{2.2186297957}{2.133296107} \\
\end{array}$ & $\begin{array}{l}2.2 .28627957 \\
.2133296107 \\
\end{array}$ & & $\begin{array}{l}1.9966765161 \\
1.919966496 \\
\end{array}$ & $\begin{array}{l}0.22186279 \\
0.21332961\end{array}$ & $\begin{array}{l}0.2735585859 \\
0.263055951 \\
\end{array}$ & $\begin{array}{l}2.462297305 \\
2.36759365 \\
\end{array}$ & 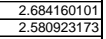 \\
\hline 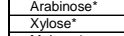 & $\begin{array}{l}\frac{19.66390058}{3.277316872} \\
\end{array}$ & $\begin{array}{l}1.2626468666 \\
0.21044144 \\
\end{array}$ & & & $\begin{array}{l}18.826897753 \\
.104979032 \\
\end{array}$ & $\begin{array}{l}\frac{18.626987753}{3.104979032} \\
\end{array}$ & $\begin{array}{l}1.0430207253 \\
0.172337839 \\
\end{array}$ & $\begin{array}{l}1.0430277553 \\
0.1723378399 \\
\end{array}$ & 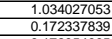 & & $\begin{array}{l}0.9306224348 \\
0.155104055 \\
\end{array}$ & $\begin{array}{l}0.10302027 \\
0.01723789 \\
\end{array}$ & $\begin{array}{l}0.126264867 \\
0.221044144 \\
\end{array}$ & 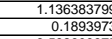 & $\begin{array}{l}1.239786504 \\
0.206351084 \\
\end{array}$ \\
\hline $\begin{array}{l}\text { Maltose }{ }^{*} \\
\text { somaltoset }^{*}\end{array}$ & $\frac{66.33949913}{72.40740191}$ & $\begin{array}{l}3.958455522 \\
4.750146622 \\
\end{array}$ & & & $\begin{array}{l}\frac{67.166538346}{68.59985578} \\
\end{array}$ & $\begin{array}{l}\frac{58.165633466}{68.5985578} \\
\end{array}$ & $\begin{array}{l}3.172594665 \\
3.807546133 \\
\end{array}$ & $\begin{array}{l}3.1722556665 \\
3.807546133 \\
\end{array}$ & $\begin{array}{l}3.1122594665 \\
3.807546133 \\
\end{array}$ & & $\begin{array}{l}2.8555551999 \\
3.426791519 \\
\end{array}$ & $\begin{array}{l}0.317295646 \\
0.38075461\end{array}$ & $\begin{array}{l}0.3955855553 \\
0.475014663 \\
\end{array}$ & $\begin{array}{l}3.562609996 \\
4.275131966 \\
\end{array}$ & $\begin{array}{r}3.897905 \\
4.655886 \\
\end{array}$ \\
\hline \begin{tabular}{|l} 
Gluc Olig* \\
LacticAcid \\
\end{tabular} & $\begin{array}{l}\frac{3154.187768}{282.842355} \\
\end{array}$ & $\begin{array}{l}204.8907336 \\
19.54667826 \\
\end{array}$ & & & $\begin{array}{l}2988.8234393 \\
268.0087566 \\
\end{array}$ & $\begin{array}{l}\frac{2988.83243933}{268.0087566} \\
\end{array}$ & $\begin{array}{l}\frac{165.88307445}{14.87547887} \\
\end{array}$ & $\begin{array}{l}\frac{165.86307445}{14.87547887} \\
\end{array}$ & $\begin{array}{l}\frac{165.88360745}{14.87547887} \\
\end{array}$ & & $\begin{array}{l}\frac{149.27676767}{13.38793098} \\
\end{array}$ & $\begin{array}{l}\frac{1.658636074}{1.48754788} \\
-\end{array}$ & $\begin{array}{l}\frac{20.480977338}{1.954667826} \\
\end{array}$ & $\frac{184.328760}{17.5920104}$ & $\begin{array}{l}200.9150679 \\
19.07558323 \\
\end{array}$ \\
\hline \begin{tabular}{|l} 
Ammonia \\
N S Solublet
\end{tabular} & 7756.877482 & 535.4973265 & & & 7348.981768 & 7348.981768 & $\begin{array}{r}1007.8957134 \\
4\end{array}$ & 407.89577134 & \begin{tabular}{|l}
407.8957134 \\
\end{tabular} & & $\begin{array}{l}367.106142 \\
\end{array}$ & 40.7895713 & 53.54973263 & 481.9475933 & 522.737165 \\
\hline 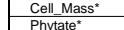 & $\begin{array}{r}0 \\
2504.45244 \\
\end{array}$ & 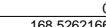 & & & 237275570 & 2372.755708 & 131.696732 & 131.696732 & 131.696732 & & 1185270588 & 13160673 & 46852526166 & 516725944 & 2681 \\
\hline $\begin{array}{l}\text { Ehananol } \\
\text { tonthon }\end{array}$ & $\begin{array}{l}418.5677982 \\
95716109\end{array}$ & $\begin{array}{l}96.27943566 \\
4248344\end{array}$ & & & 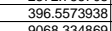 & $\begin{array}{l}396.5573938 \\
906832389 \\
9\end{array}$ & $\begin{array}{l}22.01040445 \\
5532328181\end{array}$ & 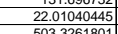 & 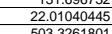 & & 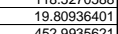 & $\frac{2.305004}{2.2014044}$ & 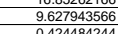 & $\frac{1.3651492}{86.651422}$ & 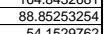 \\
\hline nPentylaceta & 10379.74209 & $\begin{array}{l}-4.244644446 \mathrm{C} \\
4.92468 \mathrm{E}-\mathrm{S}\end{array}$ & & & 900633934009 & $\begin{array}{l}98033.9229333 \\
9833 \\
\end{array}$ & 545.8191538 & 545.8191538 & $\begin{array}{l}5455.80191538 \\
5458\end{array}$ & & $\begin{array}{l}-452.953521 \\
491.2372384 \\
\end{array}$ & $\begin{array}{l}50.5261000 \\
54.5819153\end{array}$ & $\begin{array}{l}.4244644444 \\
.92468 E-10\end{array}$ & $\frac{3.0035019}{4.43221 \mathrm{E}-0 \mathrm{~S}}$ & $\begin{array}{l}54.1529662 \\
54.58191538 \\
\end{array}$ \\
\hline 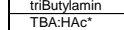 & $\begin{array}{r}0 \\
440022.7945 \\
\end{array}$ & $1.1875 E-14$ & & & $\begin{array}{r}0 \\
416884.1782 \\
\end{array}$ & $\begin{array}{r}0 \\
416884.1782\end{array}$ & $\begin{array}{r}0 \\
23138.61629 \\
\end{array}$ & \begin{tabular}{r|}
23138.61629 \\
\end{tabular} & $\begin{array}{r}0 \\
23138.61629 \\
\end{array}$ & & $\begin{array}{r}20824.75466 \\
\end{array}$ & 2313.86162 & $\begin{array}{r}1.1875 E-15 \\
0\end{array}$ & $1.06875 E-14$ & 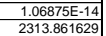 \\
\hline $\mathrm{Ca}(A C) 2^{*}$ & $\frac{0}{84896.87518}$ & 210.2893325 & & & & & $\frac{0}{84896.87518}$ & $\begin{array}{r}0 \\
84896.87518 \\
\end{array}$ & & 84896.8751 & & & $\begin{array}{r}21.02893325 \\
0\end{array}$ & 189.2603992 & \begin{tabular}{|l|l|}
189.26039992 \\
84869.851818
\end{tabular} \\
\hline 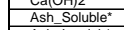 & 5004.298717 & 345.9511736 & & & 47741.147468 & 4741.147468 & 263.1512487 & $\begin{array}{l}263.1512487 \\
\end{array}$ & 263.1512487 & & 236.8361238 & 26.3151248 & 34.59511736 & 311.356056 & 377.6711811 \\
\hline 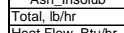 & 1699365.078 & $\begin{array}{l}84896.87511 \\
65602718\end{array}$ & & & $\frac{1529571.328}{152713}$ & $\begin{array}{l}1529571.328 \\
5251.38\end{array}$ & $\begin{array}{l}169793.7504 \\
16943\end{array}$ & 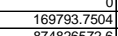 & $\begin{array}{l}84896.87518 \\
480.83\end{array}$ & 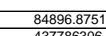 & 764407.18766 & 8489.68751 & $\begin{array}{r}8489.687518 \\
\end{array}$ & 76407.18766 & $\begin{array}{l}169793.7504 \\
-10904\end{array}$ \\
\hline fow, Btuhr & & & & & .7874066104 & & & & -437040266.2 & -437786306. & & 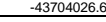 & -555032821.25 & -499529531.. & -981019924.7 \\
\hline
\end{tabular}

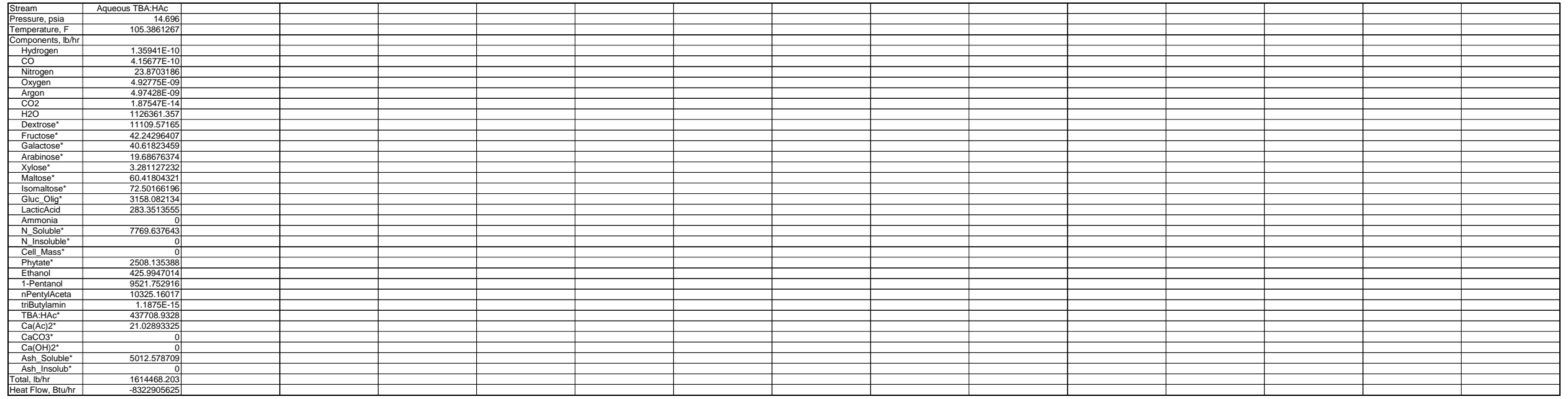


DE-FG36-03G013010

ZeaChem, Inc.

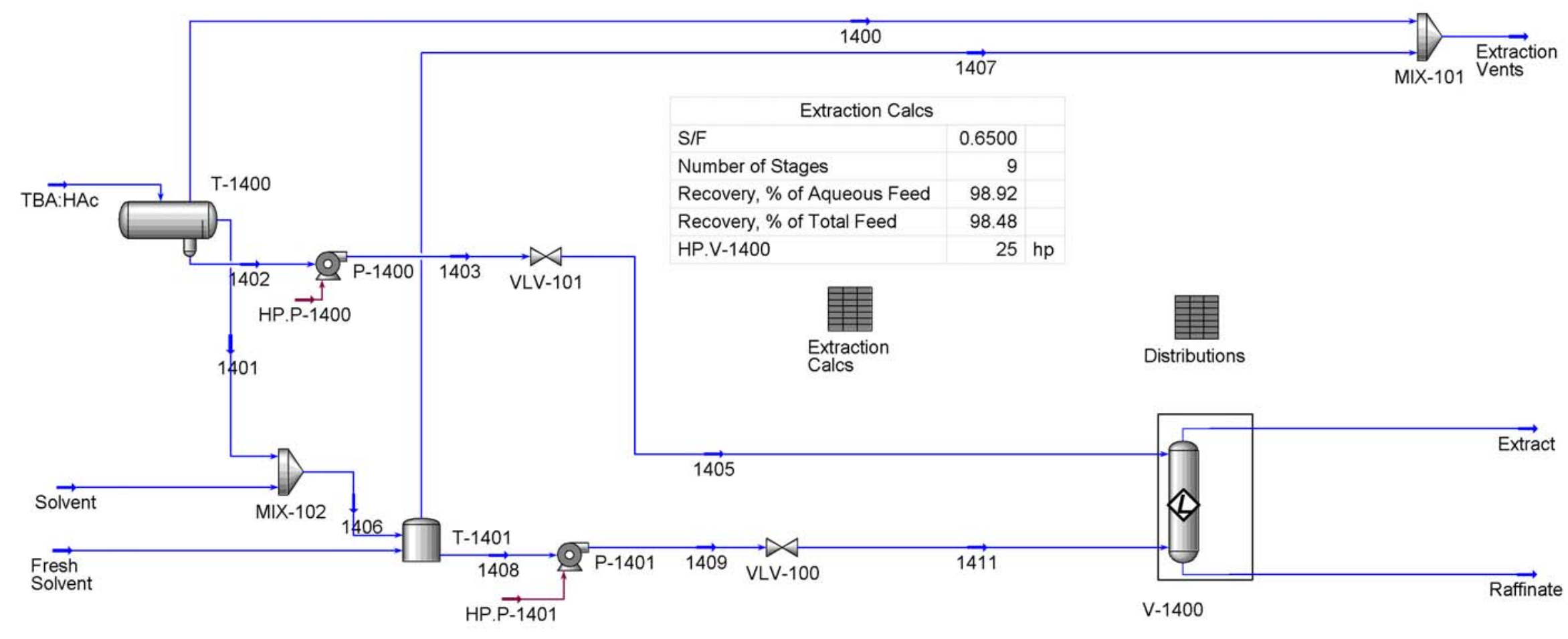


DE-FG36-03G013010

Flowsheet: Extraction (EXTR)

ZeaChem, Inc.

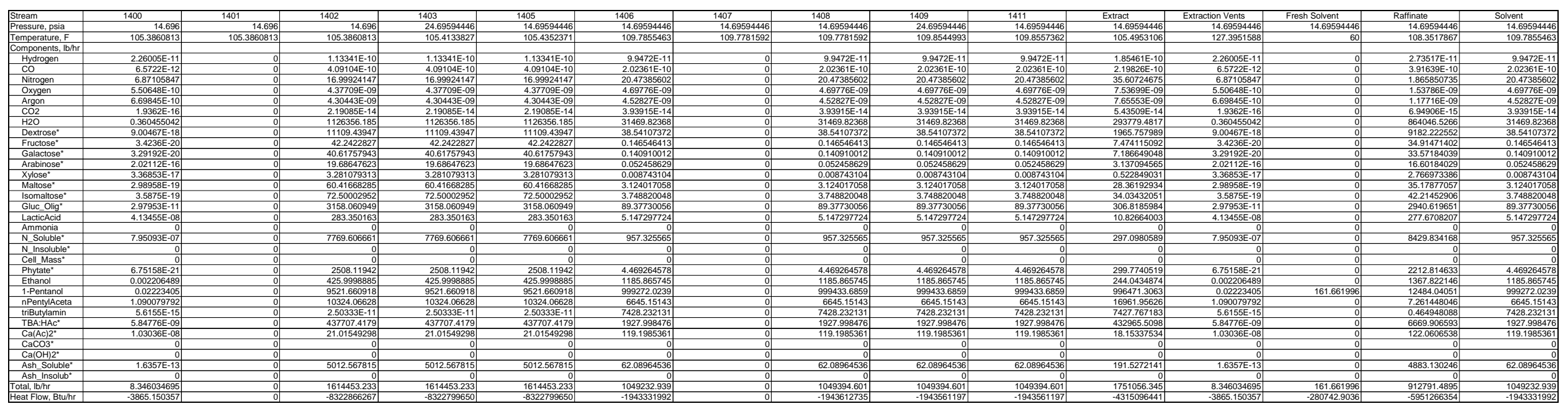

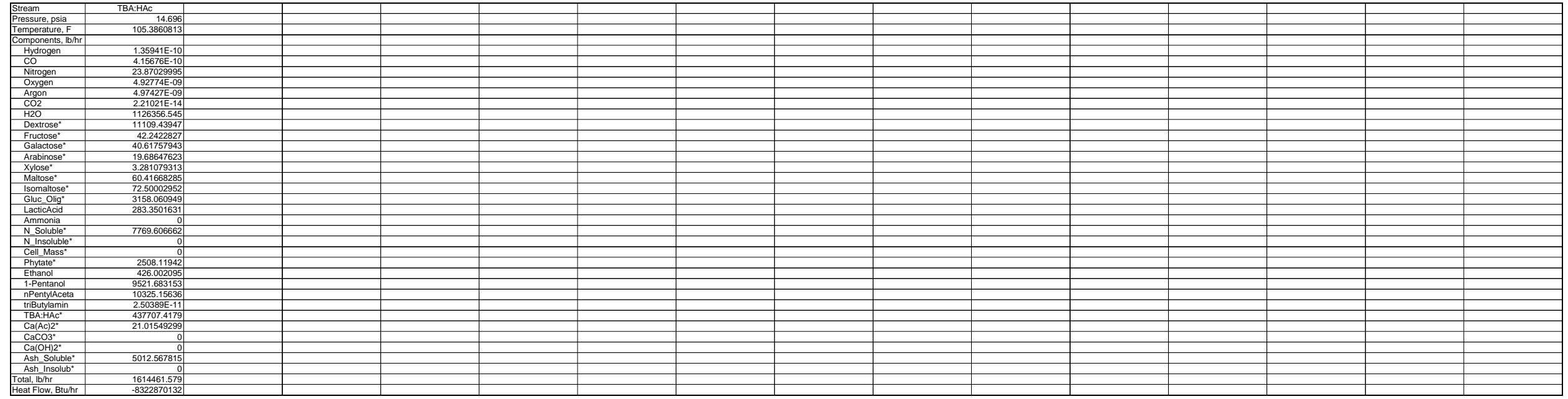


DE-FG36-03G013010

ZeaChem, Inc.

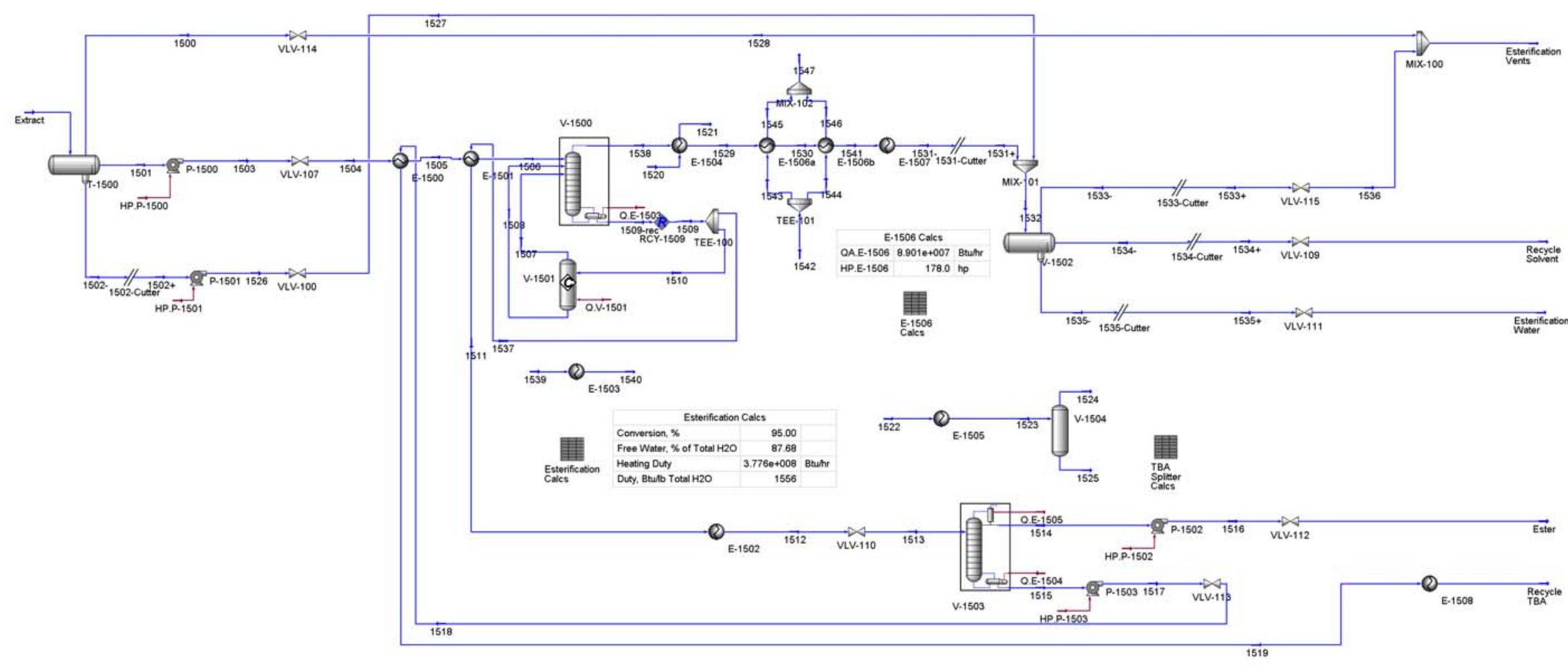


DE-FG36-03G013010

Flowsheet: Esterification + Fractionation (ESTR)

ZeaChem, Inc.

\begin{tabular}{|c|c|c|c|c|c|c|c|c|c|c|c|c|c|c|c|}
\hline $\begin{array}{l}\text { Streamme pia } \\
\text { Pressure, psia }\end{array}$ & $\begin{array}{r}15000 \\
14.65994446 \\
\end{array}$ & $\frac{1501}{15.69594446}$ & $\frac{1502+}{14.695994446}$ & $\begin{array}{l}1502- \\
14.69594446 \\
\end{array}$ & $\begin{array}{ll}1503 & 55 \\
\end{array}$ & $1504 \quad 45$ & 1505 & 1506 & $\begin{array}{ll}1507 & 35 \\
\end{array}$ & $\begin{array}{ll}1508 & 35.5 \\
\end{array}$ & 1509 & $\begin{array}{ll}1509-\text {-ec } & 35 \\
\end{array}$ & $1510 \quad 35.5$ & $\begin{array}{ll}1511 & 30.5 \\
\end{array}$ & $\begin{array}{rr}1512 \\
173.5\end{array}$ \\
\hline 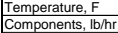 & & & & & & 105.809628 & $\begin{array}{r}129.925007 \\
\end{array}$ & & & 338.7898794 & 344.6094308 & 344.609430 & & & \\
\hline 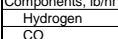 & & $\begin{array}{l}1.82594 E-10 \\
193685 E-10\end{array}$ & $\begin{array}{l}2.86707 E-12 \\
23577 \mathrm{E}-11\end{array}$ & $\begin{array}{l}2.86707-12 \\
235577-11\end{array}$ & $\begin{array}{l}\frac{1.82594 E-10}{1.96368 F-10} \\
10\end{array}$ & $\begin{array}{l}1.82594 E-1 \mathrm{C} \\
1.96368 \mathrm{E}-1 \mathrm{C}\end{array}$ & 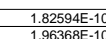 & $\begin{array}{l}\frac{1.82594-10}{1} \\
196388-10 \\
\end{array}$ & & & $\begin{array}{l}5.11847 \bar{E}-26 \\
71158 E-25 \\
\end{array}$ & $\begin{array}{l}5.12237 \mathrm{E}-2 \\
70938 \mathrm{E}-2\end{array}$ & $\begin{array}{l}4.86255 E-26 \\
6.75995-25 \\
\end{array}$ & $\begin{array}{l}2.55923 E-27 \\
3570-26 \\
\end{array}$ & $\begin{array}{l}2.55923 \mathrm{E}-27 \\
\frac{3.55789-26}{2}\end{array}$ \\
\hline $\begin{array}{l}\text { Nitrogen } \\
\text { Oxxen }\end{array}$ & & 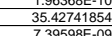 & 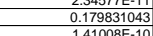 & 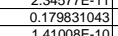 & 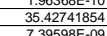 & 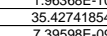 & 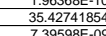 & 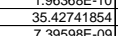 & & $3.55872 E-23$ & 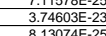 & 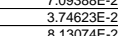 & 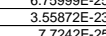 & 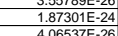 & 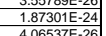 \\
\hline & & $\frac{7.54534 E-09}{\frac{7.5356-09}{53668 E-14}}$ & 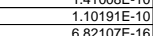 & 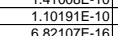 & 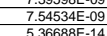 & 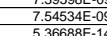 & 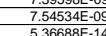 & 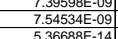 & & & $\begin{array}{l}8.103025-24 \\
1.0502-24 \\
1.1182-24\end{array}$ & 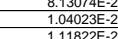 & $\begin{array}{l}\frac{9.64246-25}{9.625-25} \\
106295-25\end{array}$ & 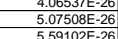 & 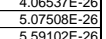 \\
\hline H2O & & 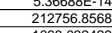 & 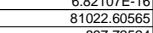 & 81022.605655 & 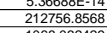 & 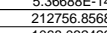 & $\frac{5.306860-14}{212756.8568}$ & $\begin{array}{l}\frac{3.306386-14}{212756.8568} \\
2\end{array}$ & & 41170.02741 & $\begin{aligned} 1.118726-24 \\
11872.68626 \\
\end{aligned}$ & 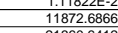 & $\begin{array}{l}1.0225-24 \\
11279.05195 \\
\end{array}$ & $\begin{array}{l}5.59120-26 \\
593.634313 \\
\end{array}$ & $\begin{array}{l}5.59102-206 \\
593.634313 \\
\end{array}$ \\
\hline $\begin{array}{l}\text { Dextrose*t } \\
\text { Frractosest }\end{array}$ & & $\begin{array}{l}1068.032429 \\
4060470735 \\
\end{array}$ & 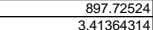 & \begin{tabular}{|l|l|}
897.72524 \\
344364314 \\
\end{tabular} & $\begin{array}{l}1068.032429 \\
4.0604770735\end{array}$ & $\frac{1068.03242 \mathrm{C}}{4006077273^{4}}$ & $\begin{array}{l}1068.032429 \\
4060040735 \\
\end{array}$ & $\begin{array}{l}1068.032429 \\
4.060470735 \\
\end{array}$ & & \begin{tabular}{|l|l|}
20292.60885 \\
77.149916
\end{tabular} & $\begin{array}{l}21360.640899 \\
8120938547\end{array}$ & $\begin{array}{l}21360.6412 \\
812038369\end{array}$ & $\begin{array}{l}20292.60885 \\
77.1499162 \\
\end{array}$ & $\begin{array}{l}1068.032045 \\
060690744\end{array}$ & $\begin{array}{l}1068.032045 \\
406046927 \\
\end{array}$ \\
\hline 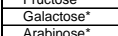 & & $\begin{aligned} 4.000429359 \\
3.9052969 \\
205147\end{aligned}$ & 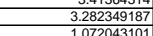 & 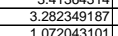 & 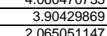 & 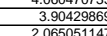 & 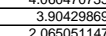 & 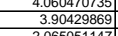 & & 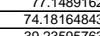 & $\begin{array}{l}\frac{8.12003958447}{78.0859471} \\
\end{array}$ & 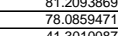 & 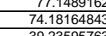 & $\begin{array}{l}\text { 4.06006469274 } \\
3.00427286 \\
\end{array}$ & 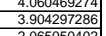 \\
\hline $\begin{array}{l}\text { Arabinose } \\
\text { Xylose }\end{array}$ & & $\begin{array}{l}\frac{2.0655051147}{0.344175133} \\
\end{array}$ & $\begin{array}{l}\frac{1.120434301}{0.178673846} \\
\end{array}$ & $\frac{1.10124243104}{0.178673846}$ & $\begin{array}{l}0.0055051147 \\
0.344175133 \\
\end{array}$ & 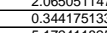 & $\begin{array}{l}2.0 .355051414 \\
0.344175133 \\
\end{array}$ & $\begin{array}{l}2.0605051449 \\
0.344175133 \\
\end{array}$ & & 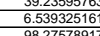 & 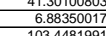 & 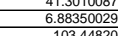 & $\begin{array}{l}3.2359535163 \\
6.539325161 \\
\end{array}$ & $\begin{array}{l}2.0605054402 \\
0.344175008 \\
\end{array}$ & 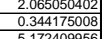 \\
\hline $\begin{array}{l}\text { Malassete } \\
\text { Isomattose }\end{array}$ & & $\begin{array}{l}5.1122411825 \\
6.206904349 \\
\end{array}$ & $\begin{array}{r}233.18950744 \\
27.82740402 \\
\end{array}$ & $\frac{23.1859004 \mid}{27.8270402}$ & $\frac{3.172418625}{6.206904349}$ & $\begin{array}{l}5.172441824 \\
6.20609434\end{array}$ & $\frac{5.1724241825}{6.206904349}$ & $\begin{array}{l}5.172411825 \\
6.206904349 \\
\end{array}$ & & $\begin{array}{r}98.27558911 \\
117.9311 \\
\end{array}$ & $\frac{103.4481991}{124.1380421}$ & $\frac{103.44820}{124.138044}$ & $\begin{array}{l}\frac{98.27759817}{117.93114} \\
\end{array}$ & & $\frac{1}{66902}$ \\
\hline \begin{tabular}{|l|} 
Glucc oligt \\
Lacticicaid \\
\end{tabular} & & $\begin{array}{l}299.7568347 \\
10.56527241 \\
\end{array}$ & $\begin{array}{l}7.061785144 \\
0.0265363646 \\
\end{array}$ & $\begin{array}{ll}7.061785144 \\
0.2653683644 \\
\end{array}$ & $\begin{array}{l}299.7568347 \\
10.56127241 \\
\end{array}$ & $\begin{array}{l}299.756834 \\
1.56512724\end{array}$ & $\begin{array}{l}299.7568347 \\
1.0562127241 \\
\end{array}$ & $\begin{array}{l}299.7568347 \\
10.5127241\end{array}$ & & $\begin{array}{l}5695.377222 \\
200.07171559 \\
\end{array}$ & $\begin{array}{l}\frac{5995.133919}{2010.544062} \\
\end{array}$ & $\frac{5995.13402}{20.5444}$ & $\frac{5695.3772239}{200.0171859}$ & $\begin{array}{l}299.756696 \\
10.52722031 \\
\end{array}$ & $\begin{array}{ll}299.756 \\
10.527222 \\
\end{array}$ \\
\hline \begin{tabular}{|l|} 
Ammonia \\
N_Soluble
\end{tabular} & & $\begin{aligned} 295.8631636 \\
\end{aligned}$ & $\begin{array}{r}0 \\
1.234919048 \\
\end{array}$ & \begin{tabular}{r|r|}
1.234919048 & 0 \\
\end{tabular} & $\begin{array}{r}0 \\
295.8631636 \\
\end{array}$ & $295.863163 \mathrm{C}$ & 295.8631636 & $\begin{array}{r}0 \\
295.8631636 \\
\end{array}$ & & $\underset{5619.23321}{\longrightarrow}$ & $\frac{0}{5914.982327}$ & 5914.98243 & $\frac{5619.23321}{0}$ & $\begin{array}{r}0 \\
295.7491163 \\
\end{array}$ & $\begin{array}{r}295.7491163 \\
\end{array}$ \\
\hline $\begin{array}{l}\text { Nolnsolublet } \\
\text { Cell_Mass }\end{array}$ & & 0 & 0 & of & 0 & $\mathrm{c}$ & 0 & 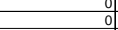 & & 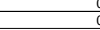 & 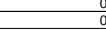 & 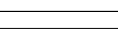 & 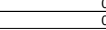 & 0 & \\
\hline Phyta & & $\begin{array}{r}\frac{156.1809556}{235.972378} \\
2\end{array}$ & $\begin{array}{l}143.5930449 \\
8.071125152 \\
\end{array}$ & $\begin{array}{l}143.5930449 \\
8.071125152 \\
\end{array}$ & $\frac{156.1809546}{233.973278}$ & $\frac{156.1809546}{235.92378}$ & $\frac{156.1809546}{235.972378}$ & $\begin{aligned} \frac{156.1809546}{233.972378} \\
\end{aligned}$ & & $\frac{2967.437077}{1.57922116}$ & $\begin{array}{l}3123.617972 \\
1.66238063 \\
\end{array}$ & $\begin{array}{l}3123.618022 \\
1.62636394\end{array}$ & $\begin{array}{l}2967.437073 \\
1.57922116 \\
\end{array}$ & $\begin{array}{l}156.1808986 \\
0.08312603\end{array}$ & \\
\hline \begin{tabular}{|l|} 
1-Pentanol \\
\end{tabular} & & 994970.9774 & $\frac{1500.410289}{15020289}$ & 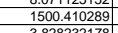 & 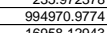 & 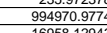 & 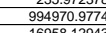 & $\begin{array}{l}9939972.09774 \\
9690.9744 \\
\end{array}$ & & 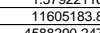 & 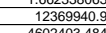 & 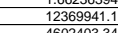 & 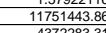 & 618497.0451 & 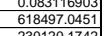 \\
\hline \begin{tabular}{|l} 
nPeenty/ceta \\
triButylamin \\
\end{tabular} & & $\frac{16958.19243}{7427.639223}$ & $\begin{array}{l}3.828324118 \\
0.128572193 \\
\end{array}$ & . & $\begin{array}{l}10588.19943 \\
7427.639223 \\
\end{array}$ & 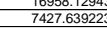 & 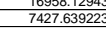 & $\begin{array}{l}16598.129433 \\
77427.639223 \\
\end{array}$ & & $\begin{array}{r}4588390.24 \\
6284425.28 \\
\end{array}$ & $\begin{array}{l}\frac{600240.3484}{6291455.386} \\
\end{array}$ & 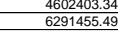 & $\begin{array}{l}3372283.31 \\
5976882.617 \\
\end{array}$ & $\begin{array}{r}230120.1742 \\
314572.7693 \\
\end{array}$ & $\begin{array}{l}2030120.1742 \\
314572.7693 \\
\end{array}$ \\
\hline \begin{tabular}{|l|l|} 
TBA:HAC* \\
\end{tabular} & & $\begin{array}{l}428611.0354 \\
11.957170168 \\
\end{array}$ & $\begin{array}{l}4354.5077744 \\
0.0196275043\end{array}$ & $\begin{array}{l}4354.5077744 \\
0.1962575033\end{array}$ & $\begin{array}{l}428611.0354 \\
17.95710168\end{array}$ & 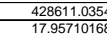 & $\begin{array}{l}428611.0354 \\
1.7951710168\end{array}$ & 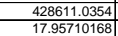 & & $\underset{341.0357881}{C}$ & $\begin{array}{l}428609.8483 \\
3585.9550401 \\
\end{array}$ & $\begin{array}{l}428609.848 \\
3858.953046 \\
\end{array}$ & $\begin{array}{l}4071199.3559 \\
341.0357881\end{array}$ & $\begin{array}{l}21430.49241 \\
17.94925201\end{array}$ & 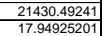 \\
\hline$(\mathrm{OH})^{2^{*}}$ & & & & & & & & & & & & & & & \\
\hline & & 184.50206831 & 7.025157981 & 7.025157981 & 184.5020 & 184.56 & 184.56 & 184.502068 & & 3500.5380045 & 3690.040048 & 3699.04011 & 3505.538045 & 184.502 & 18 \\
\hline total, bho hr & & $\frac{1663050.645}{3.67502029}$ & $\frac{88005.79688}{560214137}$ & $\begin{array}{l}88005.79688 \\
56211937\end{array}$ & $\frac{1663050.645}{3.67564323}$ & 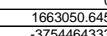 & $\frac{1663050.645}{63725698}$ & 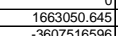 & & $\begin{array}{l}22558105.5 \\
202030965\end{array}$ & $\begin{array}{l}23745372.98 \\
306352128\end{array}$ & $\begin{array}{l}23745373 . \\
30325313 \\
3\end{array}$ & $\begin{array}{l}22558104.38 \\
2201020.35\end{array}$ & $\begin{array}{l}1187268.649 \\
1\end{array}$ & $\begin{array}{l}187268.649 \\
63685657\end{array}$ \\
\hline
\end{tabular}

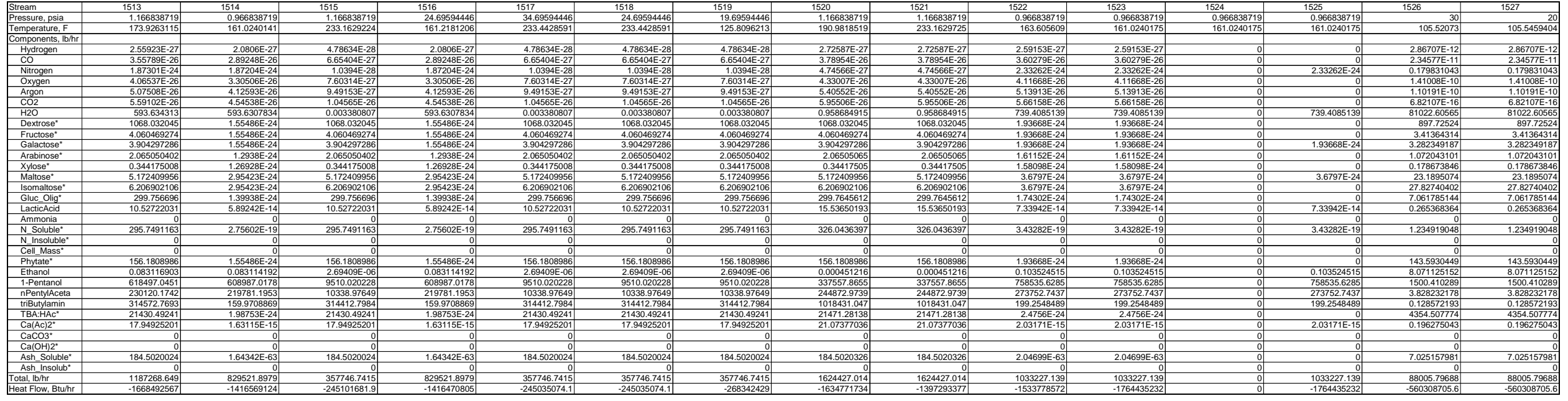


DE-FG36-03G013010

ZeaChem, Inc.

\begin{tabular}{|c|c|c|c|c|c|c|c|c|c|c|c|c|c|c|c|}
\hline-1 & $\frac{1528}{146959446}$ & 1529 & 1530 & $1531+$ & 1531. & & $1533+$ & 1533- & $1534+$ & 1534. & $\frac{1535+}{155}$ & $1535-$ & 1536 & 1537 & \\
\hline $\begin{array}{l}\text { esssuru, spsia } \\
\text { mererature, } \mathrm{F}\end{array}$ & $\begin{array}{l}14.65594446 \\
377.28878 \\
\end{array}$ & $\begin{array}{r}30 \\
241.1254875\end{array}$ & $\begin{array}{r}25 \\
230.9563043 \\
\end{array}$ & & $\frac{2}{11}$ & $\frac{26}{109.205769}$ & $\frac{26}{109.205769}$ & $\frac{2 C}{109.2057697}$ & $\begin{array}{r}20 \\
109.2057697 \\
\end{array}$ & $\frac{2}{109.205769}$ & $\begin{array}{r}20 \\
109.2057697 \\
\end{array}$ & $\begin{aligned} 20 \\
109.2057697 \\
\end{aligned}$ & $\begin{array}{l}\frac{14.69594446}{1089952216} \\
\end{array}$ & $\begin{array}{r}35.5 \\
344.6094308 \\
\end{array}$ & $\begin{array}{r}255.7355964 \\
\end{array}$ \\
\hline $\begin{array}{l}\text { ofmonentsi, } \\
\text { Hyydrogen }\end{array}$ & & $1.82594 E-10$ & $1.82594 E-10$ & $1.82594 E-10$ & $1.82594 E-10$ & $1.85461 E-16$ & $\begin{array}{ll}6.84691 E-11 \\
\end{array}$ & $6.84691 E-11$ & $8.05679 \mathrm{E}-11$ & 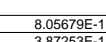 & $3.64239 \mathrm{E}-11$ & $3.64239 E-11$ & $6.84691 \mathrm{E}-11$ & $2.55923 \mathrm{E}-27$ & $\begin{array}{l}1.82594 \mathrm{E}-10 \\
10630 \mathrm{~F}-10\end{array}$ \\
\hline $\begin{array}{l}\text { Nitrogen } \\
\text { Ooxom }\end{array}$ & & 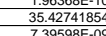 & 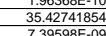 & 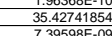 & 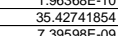 & 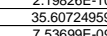 & 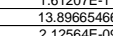 & 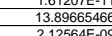 & 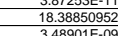 & 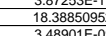 & 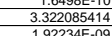 & 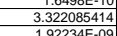 & 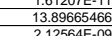 & 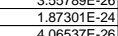 & 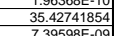 \\
\hline $\begin{array}{l}\text { oxygen } \\
\text { Argon }\end{array}$ & & 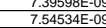 & $\begin{array}{r}.735599 \mathrm{E}-09 \\
7.5454 \mathrm{E}-09 \\
\end{array}$ & $\begin{array}{l}7.39598 \mathrm{EE}-09 \\
7.5454 \mathrm{E}-09 \\
\end{array}$ & $\begin{array}{l}7.395598 \mathrm{E}-09 \\
7.54544 \mathrm{E}-09 \\
\end{array}$ & 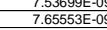 & 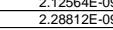 & $\begin{array}{l}2.12564 \mathrm{E}-0.9 \\
2.28812 \mathrm{E}-0 . \\
\end{array}$ & $\begin{array}{l}3.48900 \mathrm{E}-\mathrm{-g} \\
3.4707 \mathrm{E}-09 \\
\end{array}$ & $\begin{array}{l}\frac{3.48390 E-0.0}{3.4707 E-0.0} \\
\end{array}$ & $\begin{array}{l}\frac{1.922343 \mathrm{E}-09}{1.89671 \mathrm{E}-09} \\
\end{array}$ & $\begin{array}{l}\frac{1.922234 \mathrm{E}-09}{1.89671 \mathrm{E}-09} \\
\end{array}$ & $\begin{array}{l}2.12564 \mathrm{E}-09 \\
2.28812 \mathrm{E}-09 \\
\end{array}$ & $\begin{array}{l}4.00533 E-26 \\
5.07508 E-26 \\
\end{array}$ & $\begin{array}{l}7.395988-509 \\
7.545344-09 \\
\end{array}$ \\
\hline & & $\frac{5.36688 E-14}{242054.1976}$ & $\begin{array}{l}5.366888-14 \\
242054.1976 \\
\end{array}$ & $\frac{5.36688 E-14}{242054.1976}$ & $\begin{array}{l}5.33688 E-14 \\
242054.1976 \\
\end{array}$ & 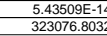 & 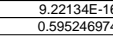 & $\begin{array}{l}9.221334 \mathrm{E}-16 \\
0.55246974 \\
\end{array}$ & $\begin{array}{l}\frac{3.93938 E-14}{29148.23041} \\
\end{array}$ & $\begin{array}{l}3.993938-1 \\
29148.2304 \\
\end{array}$ & $\begin{array}{l}\text { 1.4.43358E-14 } \\
293927.9775 \\
\end{array}$ & $\begin{array}{l}\frac{1.443385-144}{293927.9755} \\
\end{array}$ & $\begin{array}{l}9.22134 E-16 \\
0.595246974 \\
\end{array}$ & $\frac{5.59102 E-26}{593.6334313}$ & $\begin{array}{l}5.36688-14 \\
242054.1976 \\
\end{array}$ \\
\hline $\begin{array}{l}\text { Dextrose*t } \\
\text { Fuctoget }\end{array}$ & & \begin{tabular}{|c|}
$8.86734 E-10$ \\
$33718-12$
\end{tabular} & $\begin{array}{l}8.86734 E-10 \\
327108-12 \\
\end{array}$ & $\begin{array}{l}8.86734 \mathrm{E}-10 \\
33718 \mathrm{E}-12 \\
\end{array}$ & $\begin{array}{l}8.86734 E-10 \\
33718 F-12\end{array}$ & $\begin{array}{l}897.72522 \\
34132512 \\
3\end{array}$ & $\frac{7.17413 E-16}{2.72792 E-26}$ & $\begin{array}{l}7.17413 E-18 \\
277299 E-20\end{array}$ & $\begin{array}{l}31.03817124 \\
0.1180126\end{array}$ & 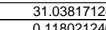 & $\begin{array}{l}8666.6870688 \\
3295621893 \\
3\end{array}$ & 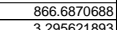 & $\begin{array}{l}7.17413 \mathrm{E}-18 \\
2.27025-20 \\
\end{array}$ & 1068.032045 & $\begin{array}{l}8.86734 \mathrm{E}-10 \\
3.3718=52 \\
\end{array}$ \\
\hline $\begin{array}{l}\text { Fucucosese } \\
\text { Galactoset }\end{array}$ & & $\begin{array}{l}\frac{3.31718 E-12}{3.24152 E-12} \\
3\end{array}$ & $\begin{array}{l}3.3 .1718 E-12 \\
3.24152 E-12 \\
\end{array}$ & $\frac{3.37118 \mathrm{E}-12}{3.24152 \mathrm{E}-12}$ & 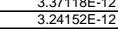 & 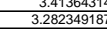 & 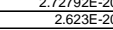 & 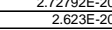 & $\begin{array}{l}\frac{0.118021246}{0.113481968} \\
\end{array}$ & $\begin{array}{l}0.18002124 \\
0.11348196\end{array}$ & 3.1688 & $\begin{array}{l}3.296521893 \\
3.168867219 \\
\end{array}$ & 2.7279272E- & $\begin{array}{l}\frac{4.060469274}{3.904297286} \\
\end{array}$ & 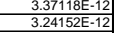 \\
\hline binosest & & 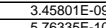 & $\begin{array}{l}3.45801 \mathrm{E}-09 \\
573235-10\end{array}$ & $\begin{array}{l}3.45801 E-09 \\
-572025=5110\end{array}$ & $\begin{array}{l}3.458011-0-0 \\
-5.75225-1\end{array}$ & 1.072043105 & $\begin{array}{l}9.95692 E-1 \\
.9562-12\end{array}$ & $9.956925-2$ & 0.031798871 & 0.031798877 & 1.0402442 & & $9.95692 E_{-}$ & & 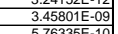 \\
\hline tos & & $\begin{array}{l}5.1 .5355 E-10 \\
1.6802 E-13\end{array}$ & 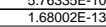 & $\frac{5.16353 E-10}{1.68002 E-13}$ & $\begin{array}{l}3.16355 \mathrm{E}-1 \mathrm{U} \\
1.68002 \mathrm{E}-13 \\
\end{array}$ & 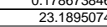 & $\begin{array}{l}\frac{1.69949 E-1}{1.2306 E-11} \\
\frac{1}{10}\end{array}$ & 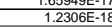 & $\frac{0.055999812}{3.11321795}$ & $\frac{0.00029981}{3.1132179}$ & $\begin{array}{l}0.17354035 \\
20.07628945 \\
\end{array}$ & $\begin{array}{l}0.1757628945 \\
20.076295 \\
\end{array}$ & $\frac{1.65994 \mathrm{E}-1 t}{1.2306 \mathrm{E}-18}$ & $\begin{array}{l}0.344417050986 \\
5.17240956\end{array}$ & $\begin{array}{l}5.76335 E-10 \\
1.6802 E-13 \\
\end{array}$ \\
\hline $\begin{array}{l}\text { Isomatasoset } \\
\text { Gluc_oligt }\end{array}$ & & $\frac{2.01602 E-13}{3.14-05}$ & $\begin{array}{r}2.016002 E-13 \\
3.14 \mathrm{E}-05 \\
\end{array}$ & $\begin{array}{r}2.01602 E-13 \\
3.14 E-05 \\
\end{array}$ & $\begin{array}{r}2.01602 E-13 \\
3.14 E-05 \\
\end{array}$ & $\begin{array}{l}27.027740402 \\
7.0618654\end{array}$ & $\begin{array}{l}\frac{1.467772 E-16}{5.30634 E-1.1} \\
5\end{array}$ & $\begin{array}{l}\frac{1.46777 E-18}{5.30634 E-13} \\
\end{array}$ & $\begin{array}{l}3.7 .75681113 \\
0.107174683 \\
\end{array}$ & $\begin{array}{l}3.75368111 \\
0.10717468 \\
\end{array}$ & $\begin{array}{l}24.091542911 \\
6.954641862 \\
\end{array}$ & $\begin{array}{l}24.091542911 \\
6.954641862 \\
\end{array}$ & $\begin{array}{l}1.446727 E-18 \\
5.30634 E-13 \\
\end{array}$ & $\begin{array}{l}\frac{6.2066092106}{299.756696} \\
\end{array}$ & $\begin{array}{r}2.0106225-13 \\
3.14--05 \\
\end{array}$ \\
\hline tiscidi & & $\frac{3.14603}{0.03404849}$ & & & 0.0340483499 & 0.299416713 & & & 0.001117087 & 0.00111708 & & 0.298299625 & $2.82654 \mathrm{E}-10$ & & \\
\hline \begin{tabular}{|l|} 
Ammonona \\
N_Soluble
\end{tabular} & & 0.113942501 & 0.113942501 & 0.113942501 & 0.113942501 & 1.348861545 & $8.46807 E-11$ & $8.46807 E-10$ & 0.00503544 & 0.0050354 & 1.343826108 & 1.343826108 & $8.46807 \mathrm{E}-10$ & 295.7491163 & 0.113942501 \\
\hline $\begin{array}{l}\text { N_linoulue } \\
\text { Cell_mass }\end{array}$ & & & & & & & & & 0 & 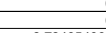 & 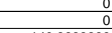 & 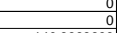 & 0 & 0 & \\
\hline 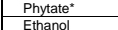 & & $\begin{array}{r}3.70777-12 \\
235.892352 \\
\end{array}$ & $\begin{array}{r}3.7077 \mathrm{~T}-12 \\
235.892352 \\
\end{array}$ & $\begin{array}{r}\frac{3.7077 \mathrm{E}-12}{235.892352} \\
\end{array}$ & $\begin{array}{r}3.7077 \mathrm{E}-12 \\
235.893252 \\
\end{array}$ & $\frac{143.5930344}{233.906360}$ & $\begin{array}{l}3.72241 E-2 \\
0.00641563 .2\end{array}$ & $\frac{3.72241 E-21}{0.006415634}$ & $\frac{2.724654964}{53.03987655}$ & $\frac{2.72465496}{532038956}$ & $\begin{array}{l}140.8683899 \\
190.940961\end{array}$ & $\begin{array}{l}140.8683899 \\
1909140691\end{array}$ & $\begin{array}{l}3.72241 E-21 \\
0.006415634\end{array}$ & $\begin{array}{l}156.1808986 \\
0.033116903\end{array}$ & $\begin{array}{r}\frac{3.7077 E-12}{23588923552} \\
\end{array}$ \\
\hline \begin{tabular}{|l|} 
1-Pentanol \\
\end{tabular} & & 230213.6299 & $\begin{array}{l}230213.6299 \\
230150290\end{array}$ & 230213.6299 & $\frac{23.0303 .529}{230213.699}$ & 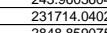 & 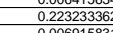 & 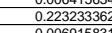 & 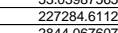 & 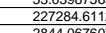 & $\begin{array}{l}4429.2005792 \\
4725792 \\
\end{array}$ & 4429.205792 & $\frac{0.223233362}{0.223362}$ & 618497.0451 & 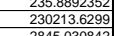 \\
\hline \begin{tabular}{|l} 
nPeenty/ceta \\
triButylamin \\
\end{tabular} & & 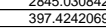 & $\frac{284.5300442}{397.4242069}$ & $\begin{array}{l}2845.0303442 \\
397.4242069 \\
\end{array}$ & $\begin{array}{l}28450.0384242 \\
397.4242069 \\
\end{array}$ & 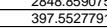 & 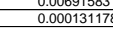 & $\frac{0.0001581178}{0.0001317}$ & $\begin{array}{r}884.406100 \\
397.521365 \\
\end{array}$ & $\begin{array}{l}2844.067100 \\
397.52136 \\
\end{array}$ & $\begin{array}{l}4.784552148 \\
0.031282878 \\
\end{array}$ & $\begin{array}{l}\frac{4.8784552148}{0.031282878} \\
\end{array}$ & 0.00001313171 & $\begin{array}{l}330120.1442 \\
31452.7693 \\
\end{array}$ & $\begin{array}{l}2845.030842 \\
397.4242069 \\
\end{array}$ \\
\hline \begin{tabular}{|l|l|} 
TBA:HAC" \\
\end{tabular} & & $\begin{array}{l}1.187126687 \\
0.007843155\end{array}$ & $\begin{array}{l}1.187126887 \\
0.007843155 \\
\end{array}$ & $\frac{1.187126887}{0.000743155}$ & $\begin{array}{l}1.187726687 \\
0.007843155 \\
\end{array}$ & $\begin{array}{l}4355.694901 \\
0.204118199\end{array}$ & $\begin{array}{l}1.36524 E-16 \\
3.91854 E-11\end{array}$ & $\frac{1.36524 \mathrm{E}-\mathrm{E} C}{3.9185 \mathrm{E}-1 \mathrm{C}}$ & $\begin{array}{r}1927.8493 \\
0.067766313 \\
\end{array}$ & $\begin{array}{l}1927.899 \\
0.06767631 \\
\end{array}$ & 2427.845602 & 2427.8456026 & $\begin{array}{l}1.365245 \mathrm{E}-10 \\
3.91854 \mathrm{E}-10\end{array}$ & & $\begin{array}{l}1.187126887 \\
1.027025 \mathrm{~d}\end{array}$ \\
\hline H) & & & & & & & & & & & & & & & \\
\hline $\begin{array}{l}\text { Ash__olulblex } \\
\text { Ash Insolubt }\end{array}$ & & $\frac{3.37345 E-07}{0}$ & $\frac{3.37345 E-07}{0}$ & $\begin{array}{r}3.37345 E-07 \\
0\end{array}$ & $3.37345 E-0$ & 7.025158315 & 1.498869E & $1.49869 \mathrm{E}-$ & 0.0262 & 0.0262 & 6.9 & 6.9989 & $1.49869 \mathrm{E}-15$ & & $\begin{array}{ll}5 E-07 \\
=0\end{array}$ \\
\hline $\begin{array}{l}\text { tal, bl blhr } \\
\text { at Flow, Btu/hr }\end{array}$ & & 475782.942Z & 475782.9422 & $\begin{array}{l}4.757829 .4222 \\
-20364877749\end{array}$ & $\begin{array}{l}475782.9422 \\
-203848770\end{array}$ & 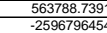 & 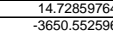 & $\frac{1.4 .72859764}{-36499791816}$ & $\begin{array}{r}261714.796 \\
-595377190.8\end{array}$ & 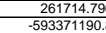 & 302059.2145 & 302059.2145 & $\begin{array}{l}1.47225597964 \\
3655.552596\end{array}$ & 268.649 & 1220 \\
\hline
\end{tabular}

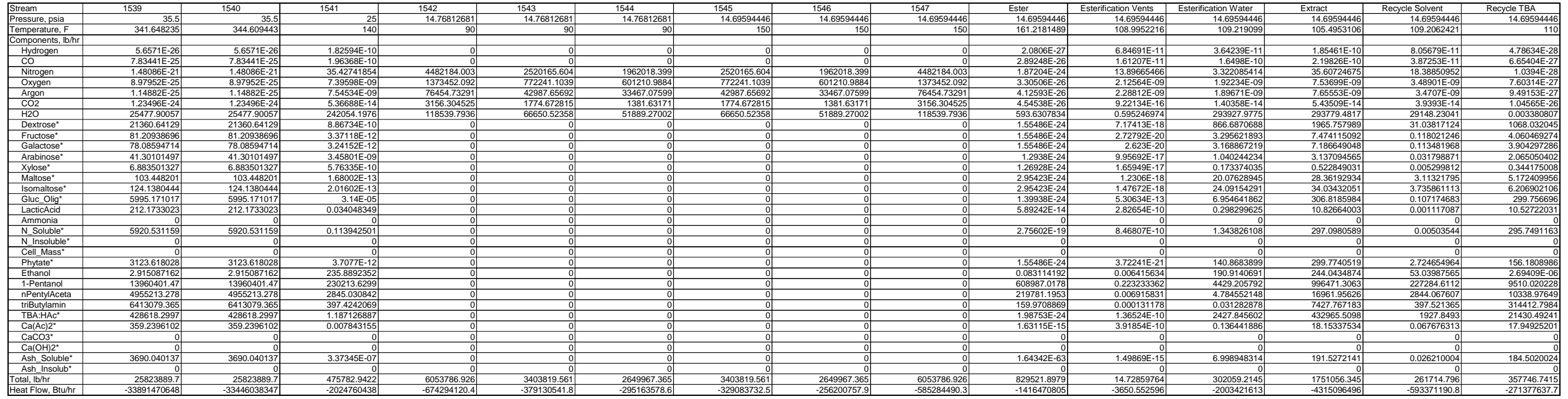


DE-FG36-03G013010

ZeaChem, Inc.

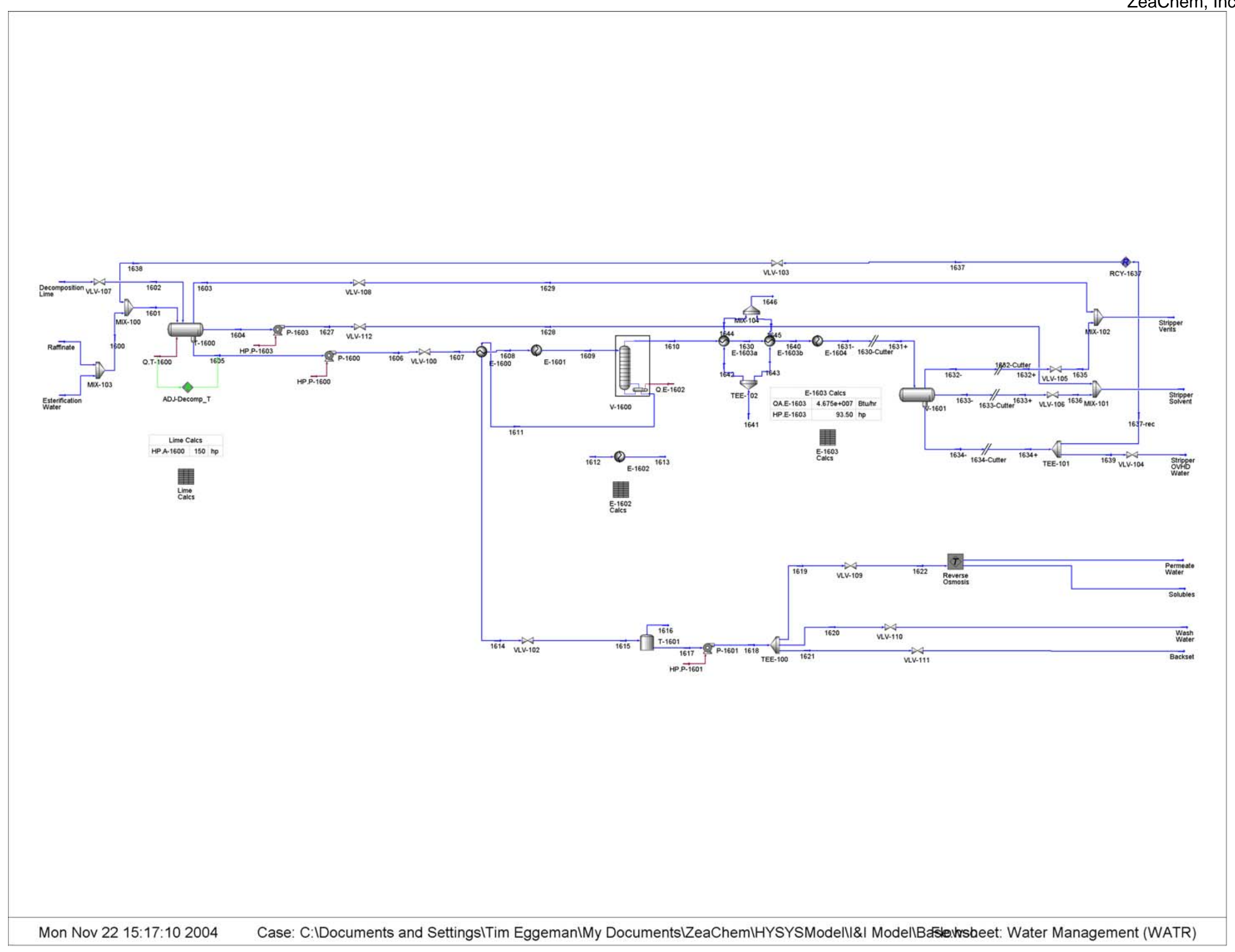


DE-FG36-03G013010

Flowsheet: Water Management (WATR)

ZeaChem, Inc.

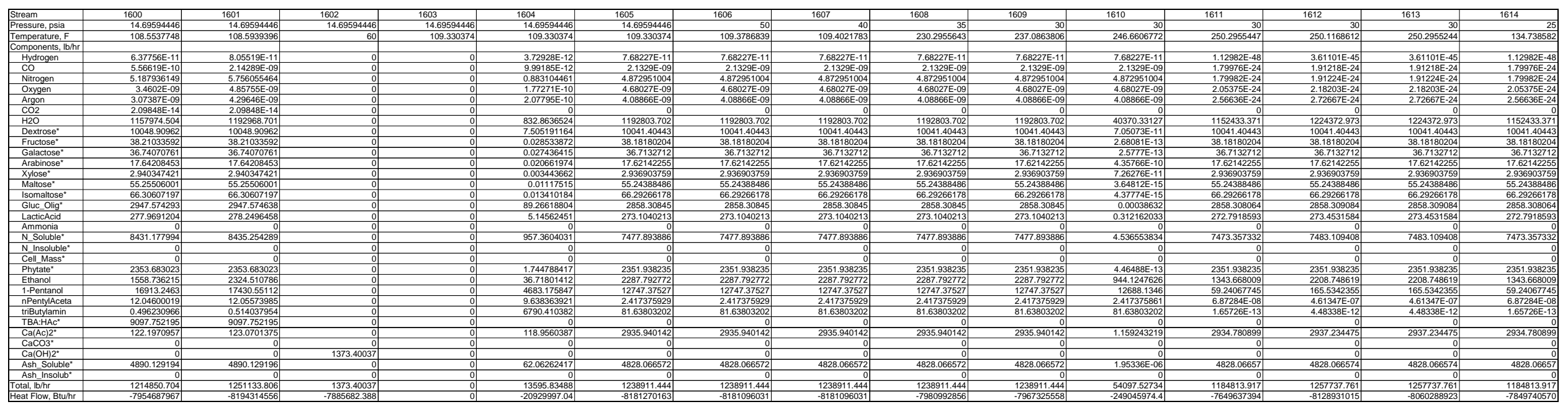

\begin{tabular}{|c|c|c|c|c|c|c|c|c|c|c|c|c|c|c|c|}
\hline $\begin{array}{l}\text { ream } \\
\text { reassure, psia }\end{array}$ & $\begin{array}{l}1615 \\
14.69594446 \\
134569793 \\
\end{array}$ & \begin{tabular}{|l|l|}
1616 \\
14.69594446 \\
134569793
\end{tabular} & $\begin{array}{l}1617 \\
14.69594466 \\
134569793 \\
\end{array}$ & \begin{tabular}{|l|}
1618 \\
44.69594446 \\
13499302 \\
\end{tabular} & \begin{tabular}{|l|l|}
1619 \\
44.69594446 \\
134993012
\end{tabular} & $\begin{array}{l}1620 \\
4.69594446 \\
13799301 \\
\end{array}$ & \begin{tabular}{|l|l|}
1621 \\
44.69594446 \\
13499302
\end{tabular} & $\begin{array}{l}1622 \\
\frac{14.6959444}{1386671} \\
\end{array}$ & $\begin{array}{l}1627 \\
24.69594446 \\
10900059 \\
\end{array}$ & \begin{tabular}{|l|l|}
1628 \\
14.69594446 \\
109022166 \\
\end{tabular} & 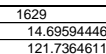 & 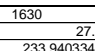 & $1631+$ & $1631-$ & $\begin{array}{rr}1632+ & 25 \\
& 110 \\
\end{array}$ \\
\hline \begin{tabular}{|l} 
Temperature, $\mathrm{F}$ \\
Components, $\mathrm{b} / \mathrm{hr}$ \\
\end{tabular} & & & & & & & $\begin{array}{l}134.7993012 \\
2\end{array}$ & & 109.4000599 & $\begin{array}{l}109.4024166 \\
\end{array}$ & & 233.940334 & & & \\
\hline \begin{tabular}{|l|} 
Hydrogen \\
Co \\
\end{tabular} & 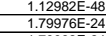 & & & & & & & & $\begin{array}{l}3.72928 E-12 \\
9.99185 E-12 \\
\end{array}$ & $\begin{array}{l}3.72928 E-12 \\
9.99985-12.12 \\
\end{array}$ & & $\begin{array}{l}7.682727-1 \\
2.1329 E-0.0 \\
\end{array}$ & $\begin{array}{l}7.68272 \\
2.1329 \\
\end{array}$ & $\begin{array}{r}7.6 .622727 \\
2.1329 \\
\end{array}$ & 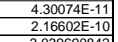 \\
\hline $\begin{array}{l}\text { Nitiogen } \\
\text { OPxyen } \\
\text { Argan }\end{array}$ & $\begin{array}{l}1.799928-24 \\
2.05375-24 \\
255636-24 \\
\end{array}$ & & & & & & & & 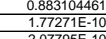 & $\begin{array}{l}0.88313046161 \\
1.7727210-10\end{array}$ & & 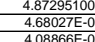 & $\begin{array}{l}4.872951004 \\
4.68027-09\end{array}$ & $\begin{array}{l}\frac{4.8729251}{4.680276} \\
4.0896656\end{array}$ & 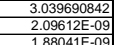 \\
\hline & 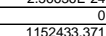 & & 1152433,371 & 1152433,33 & 7817483545 & 82576.6735 & 288108342 & 781748354 & 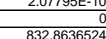 & 20 & & 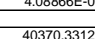 & 4.038666E & 40370 & $1.88041 E-09$ \\
\hline $\begin{array}{l}\text { Dextrose*t } \\
\text { Dextroset }\end{array}$ & $\begin{array}{c}1.0041 .00413 \\
\end{array}$ & & 10041.40443 & $\begin{array}{l}10041.40443 \\
3\end{array}$ & $\frac{6}{6611.5446475}$ & 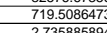 & 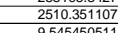 & 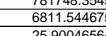 & $\begin{array}{c}8.530350324 \\
7.505191164\end{array}$ & 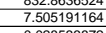 & & 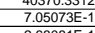 & 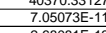 & $\begin{array}{l}7.05073 \\
7.05073\end{array}$ & $\frac{\pi .40999}{2.8995}$ \\
\hline 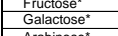 & 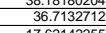 & & $\begin{array}{r}38.18878204 \\
36.71327212\end{array}$ & $\begin{aligned} 38.18180204 \\
36.71327212\end{aligned}$ & $\begin{array}{r}25.900456568 \\
24.9042938\end{array}$ & 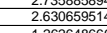 & $\begin{array}{l}9.554545611 \\
9.17837759\end{array}$ & 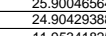 & $\begin{array}{r}0.0283533727 \\
0.027364415\end{array}$ & $\begin{array}{l}0.02853388125 \\
0.0274364615\end{array}$ & & 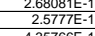 & 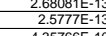 & 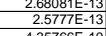 & 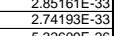 \\
\hline 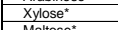 & 2.936903759 & & & (3759 & $\frac{1.99223637}{3.7275629}$ & $\frac{2.21044144}{0.209545525}$ & 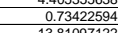 & & & $\begin{array}{ll}0.003034362 \\
0.0362\end{array}$ & & & & & 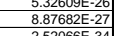 \\
\hline nathesets & 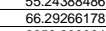 & & $\begin{array}{r}65.24358686 \\
66.29266178\end{array}$ & 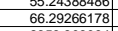 & $\begin{aligned} 3.444453517 \\
44.9693497\end{aligned}$ & $\frac{3.958435324}{4.75014625}$ & $\frac{13.85}{16.57316545}$ & $\begin{aligned} 31.44445351 \\
44.9693497\end{aligned}$ & 0.013410184 & 0.013410184 & & $\begin{array}{l}3.0478 E-1 \\
4.37774 E-1\end{array}$ & $\begin{array}{l}3.648125-2 \\
4.37774 E-\end{array}$ & & \\
\hline 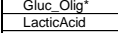 & $\begin{array}{l}28558.3080604 \\
272.7918593\end{array}$ & & $\begin{aligned} 2858.808064 \\
272.7918593\end{aligned}$ & $\begin{array}{r}2855.308064 \\
272.7918593\end{array}$ & $\begin{array}{l}1933.8221314 \\
185.0472162\end{array}$ & $\begin{array}{l}\frac{20.890977364}{19.54667826} \\
\end{array}$ & $\begin{array}{l}711.4777016 \\
68.19796482\end{array}$ & $\begin{array}{l}\frac{1988.921213}{185.047216} \\
\end{array}$ & $\begin{array}{r}8.9 .26668804 \\
5.14562451\end{array}$ & $\begin{array}{r}8.9 .26618804 \\
5.14562451\end{array}$ & & $\begin{array}{l}0.0 .0003863 \\
0.31216203\end{array}$ & $\begin{array}{c}0.000336 \\
0.3121620 \\
\end{array}$ & $\begin{array}{l}0.00038632 \\
0.312162033\end{array}$ & $\begin{array}{l}3.80412 E-1 \\
3.909793-16\end{array}$ \\
\hline \begin{tabular}{|l|} 
Ammonia \\
N_Solublet
\end{tabular} & $\frac{0}{7473.357332}$ & & $\frac{0}{74773.357332}$ & $\begin{array}{r}7473.35732 \\
\end{array}$ & $\frac{0}{5069.520673}$ & 535.497326 & 1868.339333 & 5069.520677 & $\frac{0}{957.3604031}$ & 957.3604031 & & 4.53655383 & 4.536553834 & $\frac{0}{4.536553834}$ & 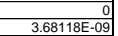 \\
\hline 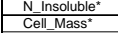 & & & & & & & & & & & & & & & \\
\hline \begin{tabular}{|c|} 
Phyyatat \\
Ethanol \\
\end{tabular} & $\begin{array}{l}2351.93323539 \\
1343.668000\end{array}$ & & $\begin{array}{l}2351.938225 \\
1343.668000\end{array}$ & $\begin{array}{l}2355.1938235 \\
1343.688009\end{array}$ & \begin{tabular}{|l}
15555.47759 \\
911.471573 \\
\end{tabular} & $\begin{array}{l}166.5262166 \\
96.27943566\end{array}$ & $\begin{array}{l}587.9845587 \\
3355.9170023\end{array}$ & $\begin{array}{l}15595.47255 \\
911.471571 \\
\end{array}$ & $\begin{array}{l}\frac{1.744788417}{36.717004142} \\
\end{array}$ & $\begin{array}{l}1.744788417 \\
3 \\
36.7170041212\end{array}$ & & 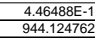 & $\begin{array}{l}4.46888 E-13 \\
944.1247626\end{array}$ & 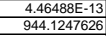 & $\begin{array}{l}1.579072-35 \\
0.03590056\end{array}$ \\
\hline $\begin{array}{l}\text { 1-Pentanol } \\
\text { nPentral/aceta }\end{array}$ & 59.24067745 & & $\begin{aligned} 59.24067745 \\
6.87284 E-08\end{aligned}$ & $\begin{aligned} 59.24067745 \\
6.878284-88\end{aligned}$ & $\begin{array}{l}40.18566655 \\
4.66216 \mathrm{E}-0 .\end{array}$ & $\begin{array}{l}4.2484444 \\
4.9468\end{array}$ & $\frac{14.81016936}{1.77821 E-08}$ & $\begin{array}{l}40.1856656 \\
4.66216-0\end{array}$ & 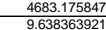 & $\begin{array}{l}46683.175847 \\
9.638353221\end{array}$ & & $\frac{12688.134}{24417325696}$ & 12688.1346 & $\begin{array}{l}12688.1346 \\
241737561\end{array}$ & $\begin{array}{l}0.0399534 \\
1.777622 .\end{array}$ \\
\hline 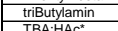 & $1.65726 \mathrm{E}-13$ & & $1.65726 \mathrm{E}-13$ & $2.65726-13$ & $\frac{1.12419 \mathrm{E}-13}{3}$ & $\begin{array}{l}4.5485-1 \\
1.1875 E-1\end{array}$ & $4.14315 E-14$ & $\begin{array}{l}4.12419 \mathrm{E}-1 \\
\end{array}$ & $\begin{array}{r}3.50503051252 \\
7790.41032 \\
\end{array}$ & $\begin{array}{l}3.55050 .410382 \\
\end{array}$ & & 81.6380320 & 81.63803202 & 81.6380320202 & $\begin{array}{l}1.246222 E-05 \\
\end{array}$ \\
\hline & 2934.780899 & & 2934.780899 & 2934.780899 & 1990.796342 & 210.289322 & 733.6952248 & 1990.79634 & 118.9560387 & 118.9560387 & & 1.15924 & 1.159243219 & 1.1592432 & $3.61918 \mathrm{E}$ \\
\hline & & & & & & & & & & & & & & & \\
\hline$\frac{1}{15 \text { Solublet }}$ & 4828.0665 & & 4828.06657 & 4828.06657 & 3275.098754 & 345.951173 & 1207.016642 & 327 & 62. & 62. & & 1.95 & 1.9533 & 1.95 & $5.5386 \mathrm{E}-22$ \\
\hline tal, labhrth & 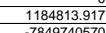 & & 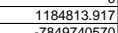 & 1184813.917 & 803713.5624 & 84896.87512 & 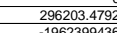 & $\begin{array}{l}803713.562 \\
-5324747182\end{array}$ & $\frac{13595.83488}{-2099233198}$ & $\begin{array}{l}13595.83488 \\
-29093199\end{array}$ & & $\begin{aligned} 54097,5273 \\
-292702726\end{aligned}$ & $\frac{54097.52}{-297282}$ & $\begin{array}{l}54097.52 \\
-297284 \\
\end{array}$ & $\frac{3.220797627}{-7.74917966}$ \\
\hline
\end{tabular}


DE-FG36-03G013010

ZeaChem, Inc.

\begin{tabular}{|c|c|c|c|c|c|c|c|c|c|c|c|c|c|c|c|}
\hline 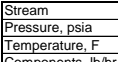 & \begin{tabular}{|r|}
$1632-$ \\
110 \\
10 \\
\end{tabular} & 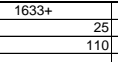 & \begin{tabular}{|r|}
1633. \\
\\
$\quad 110$ \\
\end{tabular} & $\begin{aligned} 1634+ \\
\\
1\end{aligned}$ & $1634-$ & \begin{tabular}{|c|}
1635 \\
14.65954446 \\
109.8070734 \\
\end{tabular} & \begin{tabular}{|l|l|}
1636 \\
14.69594446 \\
110.0004036 \\
\end{tabular} & $\begin{array}{|rr|}1637 & 25 \\
& 110 \\
\end{array}$ & \begin{tabular}{|l|}
$1637-$-ec \\
\\
$\quad 25$ \\
110 \\
\end{tabular} & \begin{tabular}{|l|l|}
1638 \\
14.6595446 \\
110.02543441 \\
\end{tabular} & \begin{tabular}{|r|}
1639 \\
$\quad 25$ \\
110 \\
\end{tabular} & \begin{tabular}{|l|}
1640 \\
\\
\\
\end{tabular} & $\begin{array}{l}\frac{1641}{14.76812681} \\
90 \\
\end{array}$ & $\begin{array}{l}1642 \\
14.76812681 \\
90\end{array}$ & $\frac{1643}{14.76812681} 90$ \\
\hline 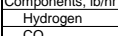 & $\begin{array}{l}4.30074 \text { E- } 11 \\
3.652-11\end{array}$ & 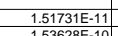 & $\begin{array}{l}1.51731 \mathrm{E}-11 \\
.553251 \\
\end{array}$ & $\frac{1.86422 E-11}{1.162670}$ & $\begin{array}{l}\frac{1.86422 E-11}{1.76267-09} \\
\end{array}$ & $\begin{array}{l}\frac{4.300744-11}{2.6062-10} \\
2.60\end{array}$ & 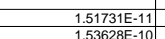 & $\begin{array}{l}\frac{1.67763 E-11}{1.58677-09} \\
\end{array}$ & $\begin{array}{l}1.6778 E-11 \\
1.5864-09 \\
\end{array}$ & $\begin{array}{l}\frac{1.67763 E-11}{1.58677-09} \\
\end{array}$ & $\frac{1.86422-12}{1.6267-10}$ & $\begin{array}{l}7.68227 E-11 \\
.0230509\end{array}$ & & & \\
\hline $\begin{array}{l}\text { Nitrogen } \\
\text { Ooxoen }\end{array}$ & 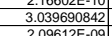 & & 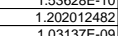 & 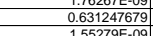 & 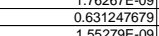 & 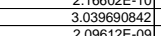 & 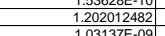 & 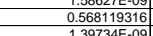 & $\frac{1.56042-2911}{0.5612911}$ & 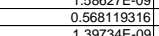 & & $\frac{2.45255004}{4.87295004}$ & & & \\
\hline $\begin{array}{l}\text { Argon } \\
\text { Argon } \\
\end{array}$ & 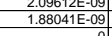 & 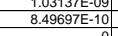 & 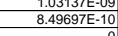 & $\begin{array}{l}\mid .1552756-09 \\
1.3586-09 \\
\mid\end{array}$ & $\begin{array}{l}1.352756-09 \\
1.3586 E-09 \\
\end{array}$ & 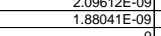 & $\begin{array}{l}8.496976-10 \\
8.49675\end{array}$ & $\begin{array}{l}1.393256-09 \\
1.2258-09 \\
0\end{array}$ & 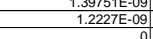 & $\begin{array}{l}1.37254-09 \\
1.2258-09 \\
\end{array}$ & $\begin{array}{l}1.532556-10 \\
1.356-10 \\
0\end{array}$ & 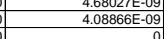 & 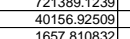 & 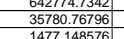 & 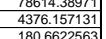 \\
\hline H2O & 0.10515256 & 1487.548648 & 1487.548648 & $\begin{array}{r}38882.67747 \\
\end{array}$ & $\begin{array}{r}38882.67747 \\
\end{array}$ & $\begin{array}{l}0.10515256 \\
0\end{array}$ & 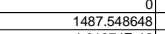 & $\begin{array}{r}34994.19692 \\
\end{array}$ & $\begin{array}{r}34994.40973 \\
\end{array}$ & \begin{tabular}{r|}
34994.19692 \\
\end{tabular} & 3888.2. & $\begin{array}{l}40370.33127 \\
0\end{array}$ & $\begin{array}{l}1657.801032 \\
62261.59495 \\
\end{array}$ & 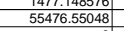 & 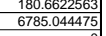 \\
\hline $\begin{array}{l}\text { Dextrose* } \\
\text { Fructosese }\end{array}$ & $\begin{array}{l}7.799956-31 \\
2.85161 E-33 \\
\end{array}$ & 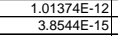 & $\begin{array}{l}1.01374 \text { EE-12 } \\
3.8544-15 \\
\end{array}$ & $\begin{array}{l}\frac{6.94936 E-1}{2.6426 E-1} \\
2.626-1\end{array}$ & $\begin{array}{l}\frac{6.94936 E-1}{2.64226 E-1} \\
2.06\end{array}$ & $\begin{array}{l}7.799955-31 \\
2.85161 E-33 \\
\end{array}$ & $\begin{array}{l}\frac{1.013774 E-12}{3.8544-15} \\
3\end{array}$ & $\begin{array}{l}6.2544 E-1 \\
2.37803 E-1 \\
\end{array}$ & 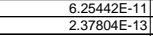 & $\begin{array}{l}\frac{6.2544 E-1}{2.37803 E-1} \\
2.0\end{array}$ & $\begin{array}{l}6.94936 E-1 \\
2.64226 E-1 \\
\end{array}$ & $\begin{array}{l}7.05073 E-11 \\
2.68081-13 \\
\end{array}$ & & & \\
\hline \begin{tabular}{|l|} 
Galactosose \\
Arabinose $^{*}$ \\
\end{tabular} & $\frac{\frac{2.77491933-33}{5.32609 E-26}}{\mid}$ & $\begin{array}{l}\frac{3.70615 E-15}{5.34413 E-12} \\
\end{array}$ & $\begin{array}{l}3.7 .766515-15 \\
5.34413-12 \\
\end{array}$ & $\begin{array}{l}2.50406 E-1 \\
4.30422 E-1 \\
4\end{array}$ & 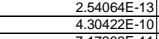 & $\frac{2.27491933-33}{5.32609 E-26}$ & 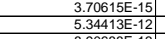 & $\begin{array}{l}2.28656 E-1 \\
3.873795-1\end{array}$ & 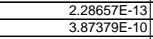 & $\begin{array}{l}2.28656 E-1 \\
3.873795-1 \\
\end{array}$ & $\begin{array}{l}2.540664 E-1 \\
4.30422 E-1 \\
4\end{array}$ & $\begin{array}{l}2.57777-13 \\
4.57666-10 \\
\end{array}$ & & & \\
\hline $\begin{array}{l}\text { XYlose } \\
\text { Malose }^{*}\end{array}$ & $\begin{array}{l}\frac{8.87862 E-27}{2.52066-34} \\
2.56\end{array}$ & 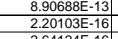 & $\begin{array}{l}8.906688-13 \\
\frac{2.20103-16}{2036}\end{array}$ & $\begin{array}{l}7.17369 E-1 \\
3.42801 E-1 \\
\end{array}$ & $\begin{array}{l}7.17369 E-1 \\
3.42801 E-1 \\
\end{array}$ & 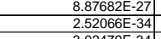 & $\begin{array}{l}\frac{8.96088 E-13}{2.201035-16} \\
2.16\end{array}$ & $\begin{array}{l}6.46532 E-1 \\
3.08524-1 \\
3\end{array}$ & 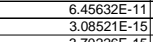 & $\begin{array}{l}6.45632 E-1 \\
3.053224 E-1 \\
3\end{array}$ & $\begin{array}{l}7.17369 E-1 \\
3.42801 E-1 \\
\end{array}$ & $\begin{array}{l}7.2 .262676-11 \\
.64812-15 \\
\end{array}$ & & & \\
\hline 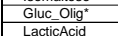 & $\begin{array}{l}3.020425-47 \\
3.80272-17 \\
3\end{array}$ & 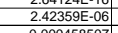 & 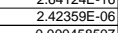 & 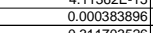 & 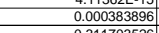 & 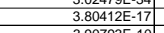 & $\begin{array}{l}2.2423459-10 \\
2.42359-06 \\
\end{array}$ & $\begin{array}{l}\frac{3.02292-15}{0.0034493} \\
0.003593\end{array}$ & $\begin{array}{l}\frac{3.02262-15}{0.00034507} \\
0.003517\end{array}$ & $\begin{array}{l}3.002291515 \\
0.00034593 \\
\end{array}$ & 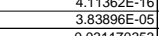 & 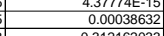 & & & \\
\hline $\begin{array}{l}\text { Ammonia } \\
\text { M sollot } \\
\end{array}$ & 0 & 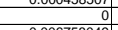 & . & $0.011 / 00500$ & 0 & 3.90793E-10 & 0.0004450007 & . & $0.2805331 / 3$ & 0.28052546 & $0.0311 / 0353$ & $\begin{aligned} 0.312162033 \\
\end{aligned}$ & & & \\
\hline \begin{tabular}{|c|} 
NSSolublex \\
N_lnsolublete
\end{tabular} & $3.68118 E-09$ & 0.006758049 & 0.006758049 & 4.529795781 & 4.529795781 & $3.68118 \mathrm{E}-09$ & 0.006758049 & 4.076295729 & 4.076816203 & 4.076295729 & $\begin{array}{r}0.452979578 \\
\end{array}$ & $\begin{array}{r}4.536553834 \\
0 \\
\end{array}$ & & & \\
\hline 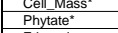 & $1.57907 E_{-35}^{-3}$ & $3.45717 \mathrm{E}-15$ & $\begin{array}{l}3.45717 E_{-15}^{0} \\
\end{array}$ & $\begin{array}{l}4.43031 E-13 \\
\end{array}$ & $\begin{array}{r}4.43031 E-13 \\
\end{array}$ & \begin{tabular}{l|l|l}
$1.57907 E-35$ \\
\end{tabular} & \begin{tabular}{l|l}
$3.45717 \mathrm{E}-15$ \\
\end{tabular} & $3.98722 \mathrm{E}-13$ & $3.98728 \mathrm{E}-13$ & \begin{tabular}{l|l}
$3.98722 E-13$ \\
\end{tabular} & $\begin{array}{r}4.43031 E-14 \\
\end{array}$ & $\begin{array}{l}4.46488 \mathrm{E}-13 \\
\end{array}$ & & & \\
\hline \begin{tabular}{|l} 
Ethanol \\
1 -Pentanol
\end{tabular} & 0.0399534044 & 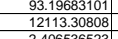 & $\frac{12113.30808}{2135053}$ & 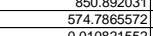 & 574.78655572 & 0.0399535040 & 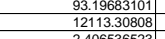 & 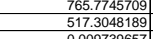 & 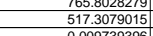 & 5177.304848989 & 57,478655722 & 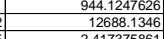 & & & \\
\hline \begin{tabular}{|l} 
nepentyceta \\
tributylamin \\
\end{tabular} & $\begin{array}{l}\frac{1.777625-5}{8.24622 E-05} \\
8\end{array}$ & $\begin{array}{l}2.4665635532 \\
81.61816139\end{array}$ & $\begin{array}{l}2.2065656533 \\
81.61816139\end{array}$ & $\begin{array}{l}0.0108215252 \\
0.019788169\end{array}$ & $\begin{array}{l}0.0108215252 \\
0.019788169\end{array}$ & $\begin{array}{l}1.77862 E-05 \\
8.24622 E-05 \\
\end{array}$ & $\begin{array}{l}2.466565523 \\
81.61816139\end{array}$ & 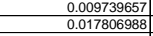 & $\begin{array}{l}0.009793936) \\
0.017809352 \\
\end{array}$ & $\begin{array}{l}0.090793657 \\
0.01786988\end{array}$ & $\begin{array}{l}0.001082155 \\
0.001978817 \\
\end{array}$ & $\begin{array}{l}2.41737575861 \\
81.63803202\end{array}$ & & & \\
\hline 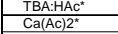 & $\begin{array}{l}3.61918 \mathrm{E}-09 \\
\end{array}$ & 0.188997706 & 0.188997706 & 0.90902451 & 0.97024 & \begin{tabular}{r|}
$3.61918 \mathrm{E}-09$ \\
\end{tabular} & 0.188997706 & \begin{tabular}{r|r}
0.873041807 \\
0.
\end{tabular} & \begin{tabular}{r|}
0.873220959 \\
0
\end{tabular} & \begin{tabular}{r|r}
0.873041807 \\
0
\end{tabular} & $\begin{array}{r}0 \\
0.097024551 \\
\end{array}$ & $\begin{array}{r}0 \\
1.159243219 \\
\end{array}$ & & & \\
\hline & & & & & & & & & & & & & & & \\
\hline 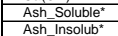 & $\frac{5.5386 E-22}{0}$ & 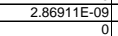 & $\begin{array}{l}2.86911 E-09 \\
0\end{array}$ & $\begin{array}{l}1.95049 E-06 \\
0\end{array}$ & $\begin{array}{l}1.95049 E-06 \\
0\end{array}$ & $5.5386 E-22$ & \begin{tabular}{|c|}
$2.86911 E-09$ \\
\end{tabular} & $\begin{array}{c}1.7554 E-06 \\
0\end{array}$ & $\begin{array}{l}1.75544 E-06 \\
0\end{array}$ & $\begin{array}{c}1.7554 E-06 \\
0\end{array}$ & $1.95049 E-07$ & $1.95336 \mathrm{E}-06$ & & & \\
\hline \begin{tabular}{|l} 
Total, libhr \\
Heat flow, Btuhrr
\end{tabular} & $\begin{array}{l}3.2202997627 \\
-1744353433 \\
\end{array}$ & 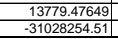 & $\begin{array}{l}137799.46494 \\
-31202554,42 \\
\end{array}$ & $\begin{array}{l}40314.83005 \\
-26262534545 \\
\end{array}$ & $\begin{array}{l}403314.83005 \\
262653545.5 \\
\end{array}$ & 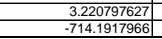 & $\begin{array}{l}13779.974699 \\
3.10225451\end{array}$ & $\begin{array}{r}36283.1021 \\
239626589.5 \\
\end{array}$ & $\begin{array}{r}36283.34705 \\
-239628109.1\end{array}$ & $\begin{array}{c}36283.10218 \\
-239626589.5\end{array}$ & $\begin{array}{l}403.483005 \\
-26625345.45\end{array}$ & $\begin{array}{c}54097.52734 \\
-295797207.5\end{array}$ & $\begin{array}{r}3179678.47 \\
-354164843.1\end{array}$ & 31556 & 385595 \\
\hline
\end{tabular}

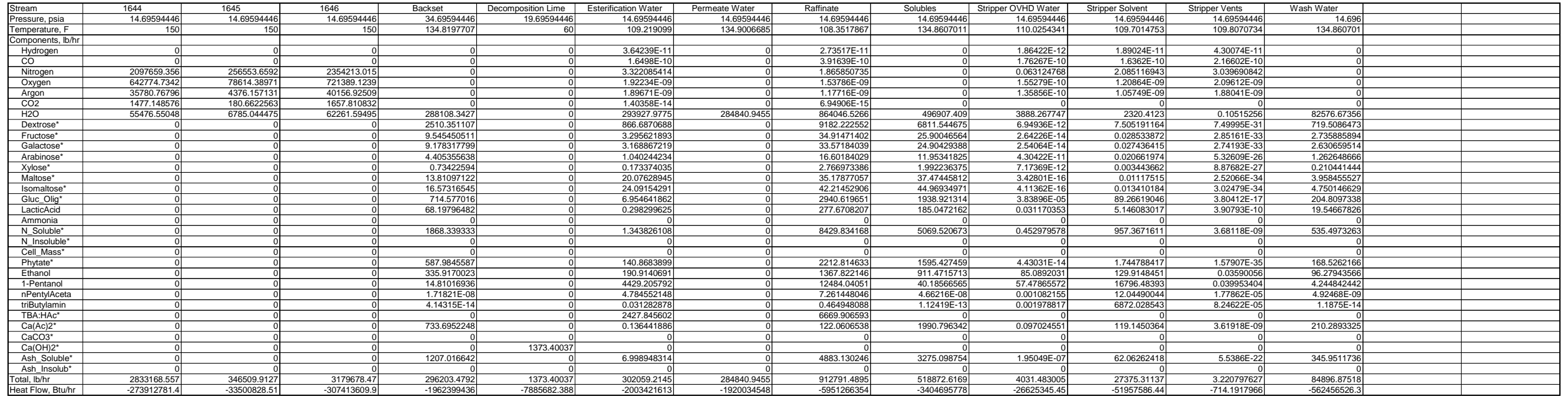




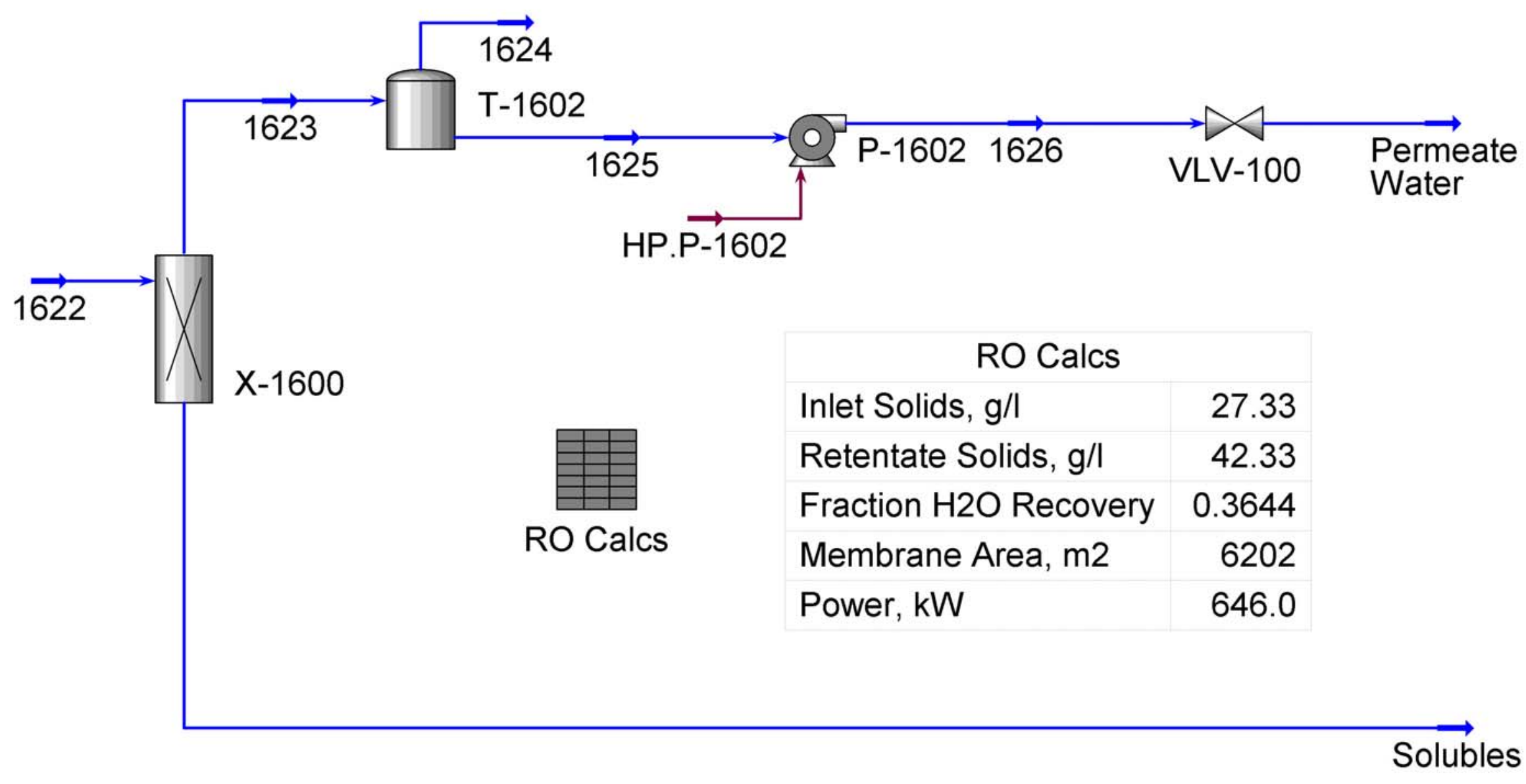


DE-FG36-03G013010

ZeaChem, Inc.

Flowsheet: Reverse Osmosis (RO2)

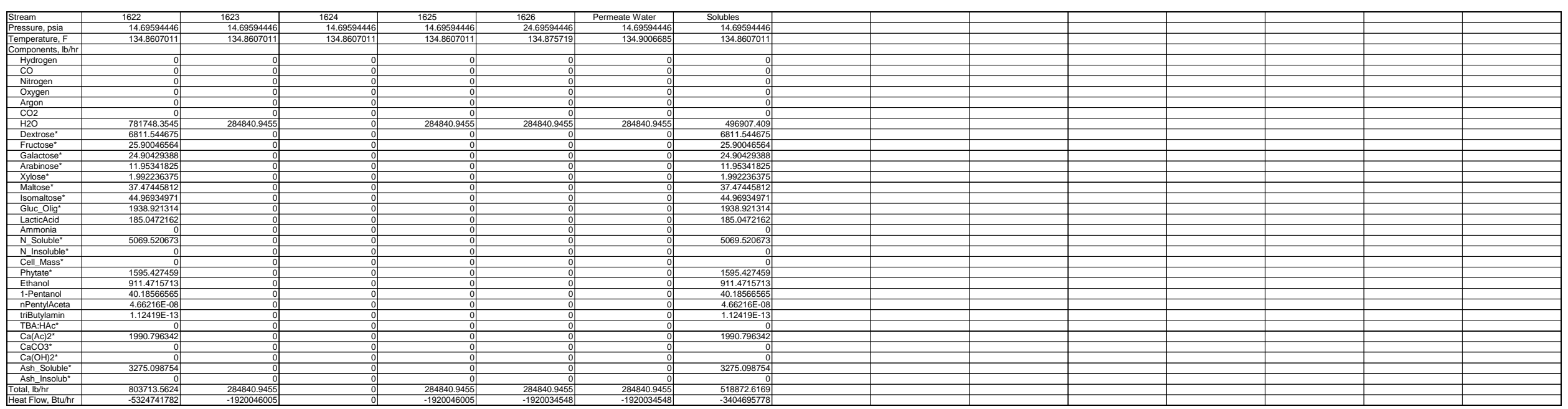


DE-FG36-03G013010

ZeaChem, Inc.

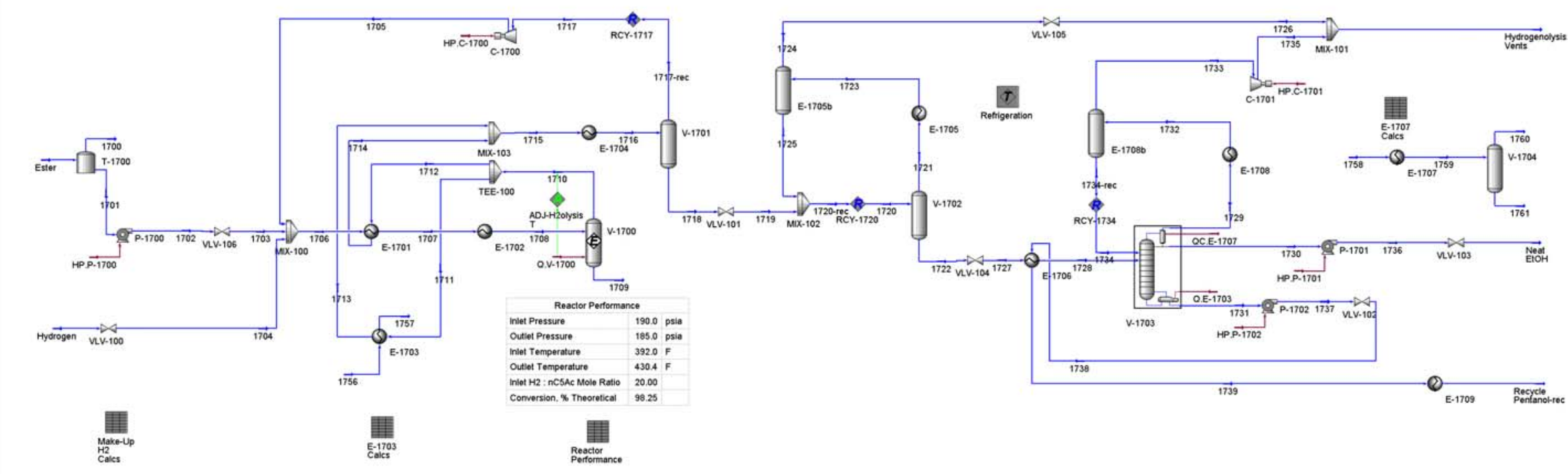


DE-FG36-03GO13010

Flowsheet: Hydrogenolysis (HYDR)

ZeaChem, Inc.

\begin{tabular}{|c|c|c|c|c|c|c|c|c|c|c|c|c|c|c|c|}
\hline $\begin{array}{l}\text { Uream } \\
\text { ressure, psia }\end{array}$ & \begin{tabular}{|l|}
17700 \\
14.69594446 \\
\end{tabular} & \begin{tabular}{|l|l|}
1701 \\
14.65594446
\end{tabular} & $1702 \quad 2$ & 1703 & 1704 & $1705 \quad 26$ & $1706 \quad 200$ & $1707 \quad 199$ & \begin{tabular}{|l|l|}
17008 & 1900 \\
\end{tabular} & 1709 & 1710 & 1711 & 1712 & 1713 & 1714 \\
\hline 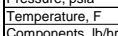 & 161.2181488 & 161.2181488 & 161.9669116 & 162.005446 & 110.0127224 & 137.5413209 & 152.1872655 & 330.1102053 & & 430.387 & \begin{tabular}{|l|l|}
430.3872161 \\
\end{tabular} & $\begin{array}{l}430.3872161 \\
\end{array}$ & $\begin{array}{l}430.3872161 \\
\end{array}$ & $238.6205^{\circ}$ & \\
\hline 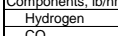 & & $\frac{2.0806 E-27}{20202526}$ & $\begin{array}{l}2.08066-27 \\
20282-26\end{array}$ & $\begin{array}{l}2.08066-27 \\
20028-26\end{array}$ & $\begin{array}{l}6766.499674 \\
090198090 \\
\end{array}$ & $\frac{61310.85104}{63207204}$ & \begin{tabular}{|l|l|}
68077.35071 \\
323121052
\end{tabular} & $\begin{array}{l}680077.35071 \\
312.1052\end{array}$ & $\frac{68077.35071}{632101521}$ & & \begin{tabular}{|l|}
61388.7008 \\
31311052
\end{tabular} & $\begin{array}{l}16192.98054 \\
2565031\end{array}$ & $\begin{array}{l}45195.72026 \\
230.45269\end{array}$ & $\begin{array}{l}16192.98054 \\
256532\end{array}$ & 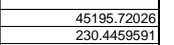 \\
\hline$\frac{1}{E t}$ & & 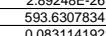 & 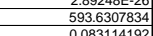 & 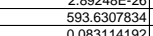 & & 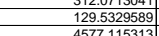 & 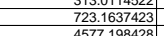 & 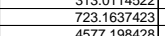 & 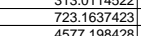 & & 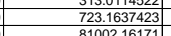 & 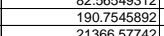 & 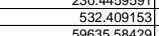 & 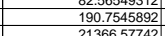 & $\begin{array}{r}\frac{230.4549}{532.49} \\
5962535.58\end{array}$ \\
\hline 1-Pentanol & & 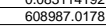 & 6089987.0178 & 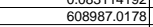 & & 2272.797089 & 611259.8149 & 611259.8149 & 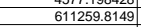 & & 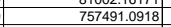 & $\begin{array}{l}190.0909 .3843 \\
1998093\end{array}$ & 557681.7076 & $\begin{array}{l}1909809.3843 \\
199893\end{array}$ & 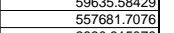 \\
\hline \begin{tabular}{|c} 
nnentylatecta \\
triButylamin
\end{tabular} & & $\begin{array}{l}215981.1953 \\
159.9708869\end{array}$ & $\begin{array}{l}215981.1953 \\
159.9708869\end{array}$ & $\begin{array}{l}21978.19953 \\
159.9708869\end{array}$ & & $\begin{array}{l}28.282669444 \\
0.42227376\end{array}$ & 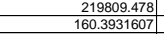 & 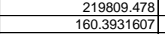 & $\begin{array}{c}\frac{2198890.478}{160.3931607} \\
\end{array}$ & & $\begin{array}{l}3845.055656 \\
160.3931607 \\
\end{array}$ & $\begin{array}{l}\mid \frac{1014.2445579}{42.30816577} \\
\end{array}$ & $\begin{array}{l}2830.815078 \\
188.0849949\end{array}$ & $\begin{array}{l}\mid 1014.2445597 \\
42.30816577\end{array}$ & $\begin{array}{l}2830.815078 \\
118.0849949 \\
\end{array}$ \\
\hline \begin{tabular}{|l} 
Total, blithr \\
Heat Flow, Btuhr
\end{tabular} & & $\begin{array}{l}\frac{892521.19979}{-1420113394} \\
-x^{2}\end{array}$ & $\begin{array}{l}\frac{8295251.19979}{-.419304164} \\
\end{array}$ & $\begin{array}{l}825921.8999 \\
-1419304164 \\
\end{array}$ & $\begin{array}{l}6767.7398822 \\
752999.145\end{array}$ & $\begin{array}{l}68631.0 .02268 \\
-1988202.566 \\
\end{array}$ & 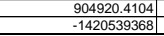 & $\begin{array}{l}\frac{904920.4104}{-1152802292} \\
\end{array}$ & 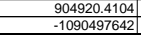 & & $\begin{array}{l}8.04923 .5584 \\
1090097657]\end{array}$ & $\begin{array}{l}238698.8111 \\
287649145.7 \mid\end{array}$ & 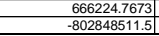 & $\begin{array}{l}\frac{236898.8111}{361835014.4} \\
36\end{array}$ & 05876 \\
\hline
\end{tabular}

\begin{tabular}{|c|c|c|c|c|c|c|c|c|c|c|c|c|c|c|c|}
\hline 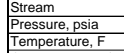 & $\begin{array}{rr}1715 & 180 \\
191.9510099 \\
\end{array}$ & 1716 & 1717 & \begin{tabular}{ll}
$1717-$-ec & 175 \\
& \multicolumn{110}{|c|}{} \\
\end{tabular} & 1718 & 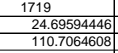 & $\begin{array}{r}1720 \\
24.69594446 \\
110.0975894 \\
\end{array}$ & \begin{tabular}{|c|}
1720 -rec \\
24.69594446 \\
110.6975895 \\
\end{tabular} & $\begin{array}{l}1721.6959446 \\
2410.6975894 \\
110.9\end{array}$ & $\begin{array}{l}1722 \\
24.69594446 \\
110.6975894 \\
\end{array}$ & $\begin{array}{l}\frac{1723}{24.69594446} \\
-20 \\
\end{array}$ & \begin{tabular}{|l|l|}
1724.6959446 \\
24.690 \\
-20 \\
\end{tabular} & $\begin{array}{l}\frac{1725}{24.69594446} \\
-20 \\
\end{array}$ & $\begin{array}{l}1726 \\
14.6959446 \\
-20.02536973 \\
\end{array}$ & \begin{tabular}{|l|}
1727 \\
9.350774237 \\
110.7636259 \\
\end{tabular} \\
\hline $\begin{array}{c}\text { Homponensi, iontr } \\
\text { Hydrogen }\end{array}$ & 61388 & 61388.70 & 613 & 61311.1273 & 34748 & . 5.373444887 & & & & 10.12923 & 66.8445337 & 66.84423345 & & 45 & 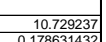 \\
\hline co & 723.1 & $\frac{313.0144522}{7723.1637423}$ & $\begin{array}{l}312.0713041 \\
129.529589 \\
\end{array}$ & & & & & & 0.999859018 & $\begin{array}{l}\frac{0.1186311432}{593.5666491} \\
\end{array}$ & 0.999585018 & & $\begin{array}{ll}7.5 \\
0.9\end{array}$ & 0.0578579289 & \\
\hline \begin{tabular}{|l} 
Ethanol \\
tolnan
\end{tabular} & & & 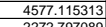 & $\begin{array}{l}4577.166229 \\
227202035\end{array}$ & $\begin{array}{l}76424.99548 \\
755182712\end{array}$ & $\begin{array}{l}76424.99548 \\
7552187122\end{array}$ & $\begin{array}{l}76459.36801 \\
7752523094\end{array}$ & $\begin{array}{l}76459.37443 \\
75525394\end{array}$ & $\begin{array}{l}35.22157661 \\
17.7231197 \\
\end{array}$ & $\begin{array}{l}76424.14643 \\
75518253\end{array}$ & 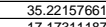 & & $\frac{34.378994543}{34.38}$ & 0.8426311855 & 64244.14643 \\
\hline \begin{tabular}{|l}
1 -Pentanol \\
neenty/Aceta \\
\end{tabular} & 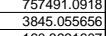 & 384451.055656 & 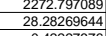 & $\begin{array}{l}\frac{2727.2820635}{28.28304343} \\
\end{array}$ & $\begin{array}{l}\frac{755518.87212}{3816.772613} \\
3813\end{array}$ & $\begin{array}{l}755218.2712 \\
3816.772613 \\
3\end{array}$ & $\begin{array}{l}\frac{755323559384}{3816.97764} \\
\end{array}$ & $\begin{array}{l}\frac{755233.53484}{3816.977924} \\
3.924\end{array}$ & $\frac{11.17311187}{0.209709206}$ & 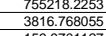 & 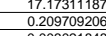 & 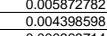 & $\frac{17.76723909}{0.205310608}$ & $\begin{array}{l}0.0005272722 \\
0.004395598\end{array}$ & $\begin{array}{l}75218.2253 \\
3816.76055 \\
315\end{array}$ \\
\hline $\begin{array}{l}\text { trtiButlyamin } \\
\text { Total, bl/hr }\end{array}$ & 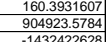 & $\begin{array}{l}\frac{160.39331607}{9004932.5784} \\
.151302632\end{array}$ & $\begin{array}{l}\frac{0.42227376}{68631.07268} \\
-.7777877 .976 \\
\end{array}$ & 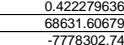 & $\begin{array}{l}\frac{1599.9070811}{836291.9716} \\
-1.1050224331\end{array}$ & $\begin{array}{l}\frac{159970808111}{836291.9716} \\
-.150522233131\end{array}$ & $\begin{array}{l}836344.6148 \\
-1505353740 \\
\end{array}$ & 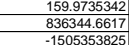 & 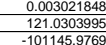 & $\begin{array}{l}\frac{159.9071127}{83623.5844} \\
-15052525944 \\
\end{array}$ & 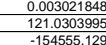 & $\begin{array}{l}\frac{0.000368714}{68.34023627} \\
-25060.574977\end{array}$ & 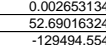 & $\begin{array}{l}\frac{0.0003636714}{68.34023627} \\
-25060.57497\end{array}$ & 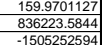 \\
\hline
\end{tabular}

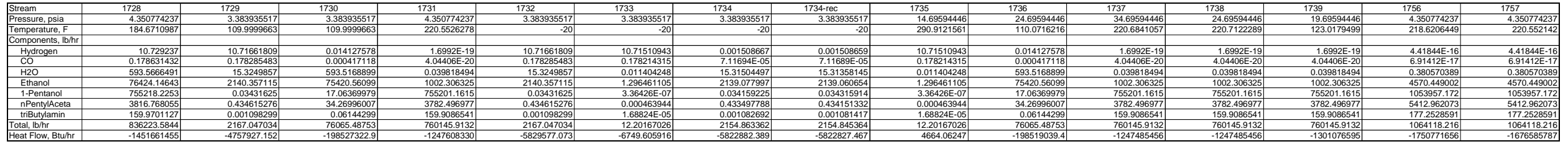

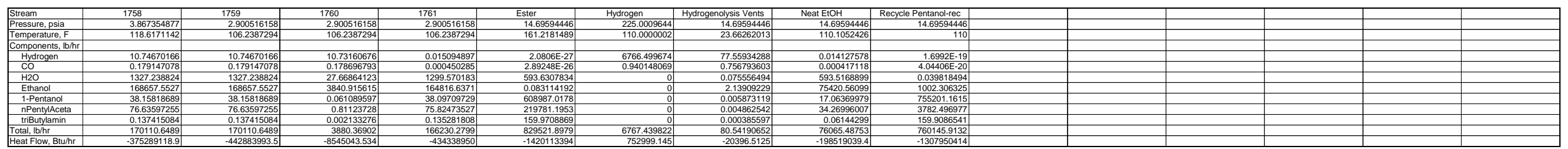


DE-FG36-03G013010

ZeaChem, Inc.

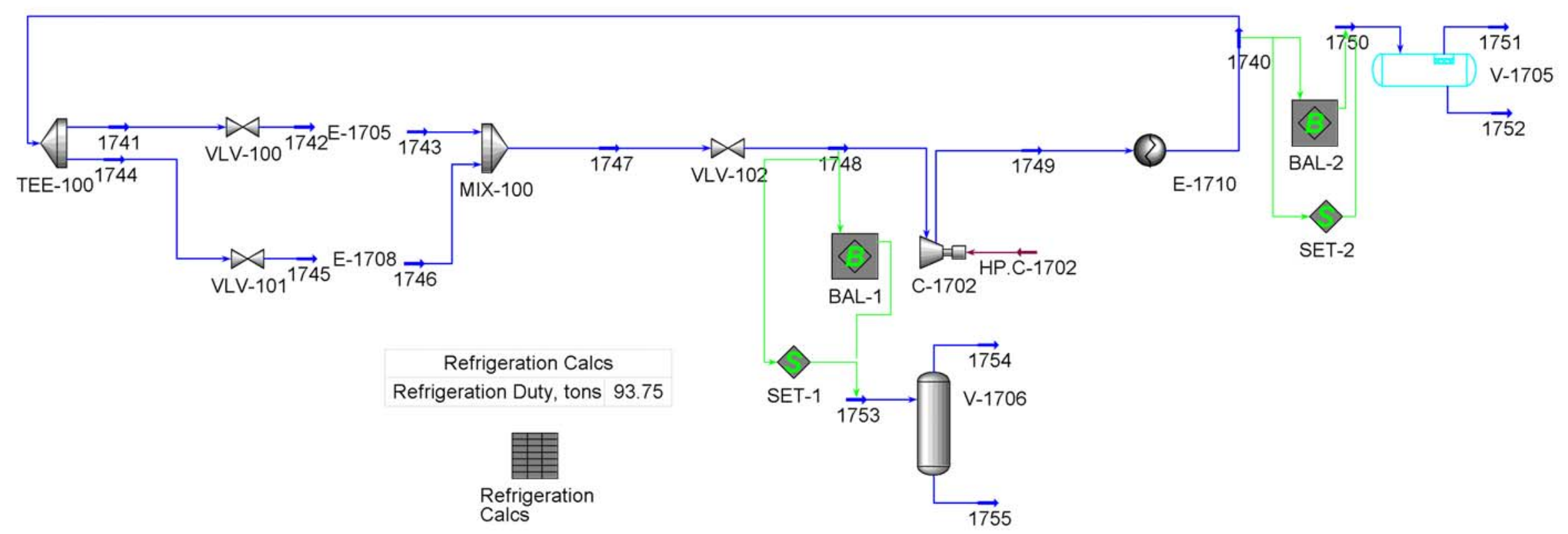


DE-FG36-03G013010

ZeaChem, Inc.

Flowsheet: Refrigeration (REFR)

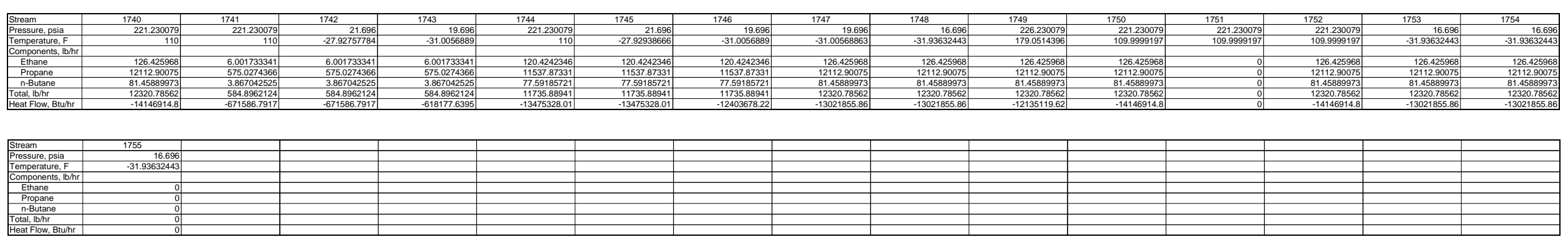




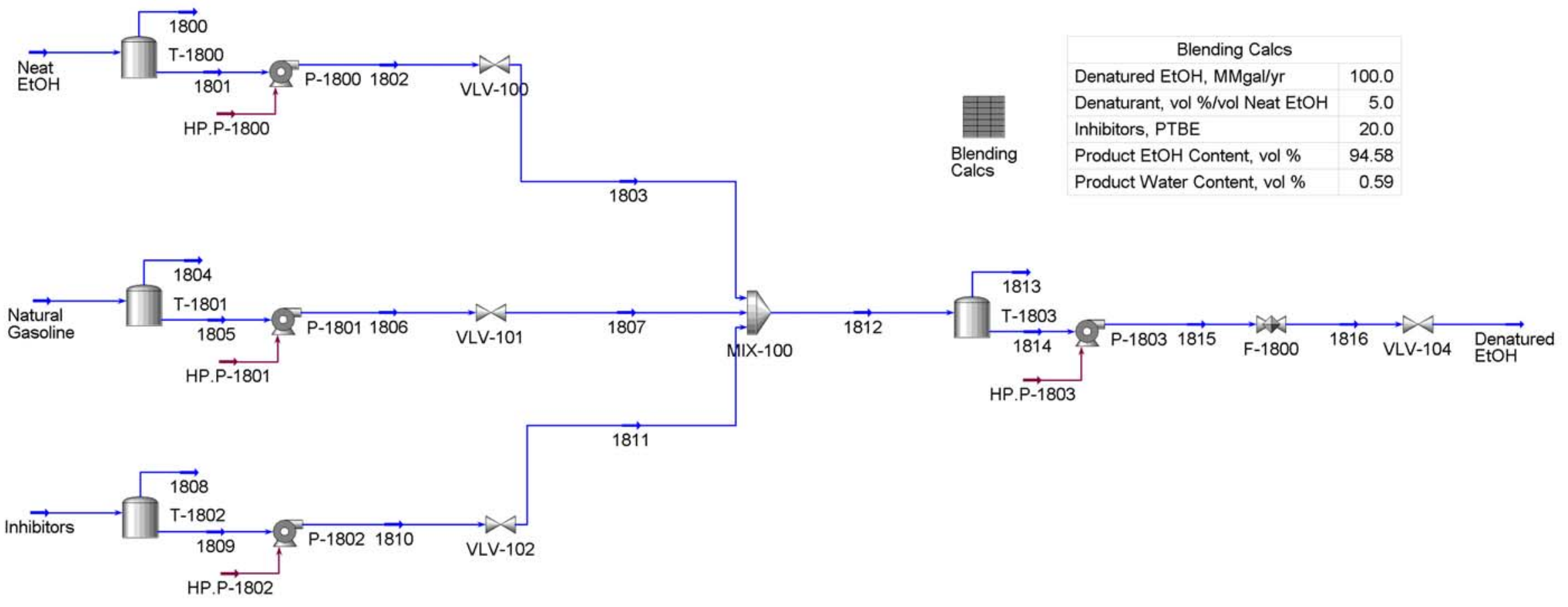


DE-FG36-03G013010

ZeaChem, Inc.

Flowsheet: Denaturing (DENA)

\begin{tabular}{|c|c|c|c|c|c|c|c|c|c|c|c|c|c|c|c|}
\hline \begin{tabular}{|l} 
Stream \\
Pressure, psia \\
\end{tabular} & $\begin{array}{l}1800 \\
14.69594446 \\
\end{array}$ & $\frac{1801}{14.69594446}$ & $\frac{1802}{24.69594446}$ & \begin{tabular}{|l}
1803 \\
14.65994446 \\
\end{tabular} & $\begin{array}{l}1804 \\
14.69594446 \\
\end{array}$ & \begin{tabular}{|l|}
1805 \\
14.695994466 \\
\end{tabular} & \begin{tabular}{|l|l|}
1806 \\
24.695944466 \\
\end{tabular} & \begin{tabular}{|c|}
1807 \\
14.69594446 \\
\end{tabular} & $\begin{array}{l}1808 \\
14.65594446 \\
\end{array}$ & $\begin{array}{l}\frac{1809}{14.69594446} \\
\end{array}$ & $\frac{1810}{24.69594446}$ & $\frac{1811}{14.69594446}$ & $\begin{array}{l}1812 \\
14.69594446 \\
\end{array}$ & $\begin{array}{l}1813 \\
14.69594446 \\
\end{array}$ & \begin{tabular}{|c|}
1814 \\
14.69594446 \\
104.7094545
\end{tabular} \\
\hline 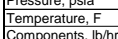 & 110.1052426 & 1110.1052426 & 110.1385613 & 1110.1721742 & & & 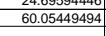 & $\begin{array}{l}4.05394434 \\
60.1123434 \\
\end{array}$ & & & $\begin{array}{l}24.05393446 \\
60.0284415 \\
\end{array}$ & $\begin{array}{l}1.4095344450 \\
60.06773999 \\
\end{array}$ & $\begin{array}{l}1.609539446 \\
104.7095444 \\
\end{array}$ & & $\begin{array}{l}140.35944404 \\
104.704545 \\
\end{array}$ \\
\hline Hydrogen & & 0.014127578 & 0.014127578 & 0.014127578 & & & & & & & & & 0.014127578 & & 0.01421274 \\
\hline $\mathrm{H} 2 \mathrm{O}$ & & $\begin{array}{r}0.0004417118 \\
593.5168899 \\
\end{array}$ & $\begin{array}{l}0.00041111199 \\
593.5168899\end{array}$ & $\begin{array}{l}0.0004117118 \\
593.5168999\end{array}$ & & & & & & 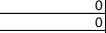 & & & $\frac{0.0004171118}{593.5168899}$ & & $\begin{array}{l}\frac{0.000417 .1}{593.51688} \\
\end{array}$ \\
\hline $\begin{array}{l}\text { Ethanol } \\
1 \text {-Pentan }\end{array}$ & & $\frac{75420.56099}{17}$ & $\frac{75420.560999}{717209090}$ & 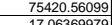 & & & & & & 5.443914015 & 5.443914015 & 5.443914015 & 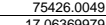 & & $\begin{array}{l}\text { T5426.0049 } \\
170360979\end{array}$ \\
\hline Apentrifictata & & 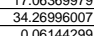 & 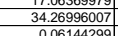 & 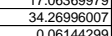 & & & & & & & & & $\frac{11.0539967}{34.2696007}$ & & 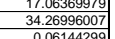 \\
\hline 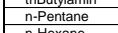 & & & & & & $\begin{array}{l}327.9458009 \\
102451014\end{array}$ & \begin{tabular}{|l|l|}
327.9458009 \\
102451041
\end{tabular} & $\begin{array}{l}327.9458009 \\
102451094 \\
\end{array}$ & & & & & $\frac{327.94585099}{32.945014}$ & & 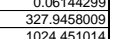 \\
\hline \begin{tabular}{|l} 
n-lentane \\
\end{tabular} & & 7606548753 & 7606548753 & 7606548753 & & $\begin{array}{l}6.870563 \\
967378\end{array}$ & $\begin{array}{l}1856.870563 \\
3202026378\end{array}$ & $\begin{array}{l}1856.870563 \\
320926738\end{array}$ & & 4015 & & & $\begin{array}{l}56.8705633 \\
801982\end{array}$ & & 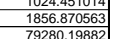 \\
\hline $\begin{array}{l}\text { Heat, } \text { Flow, Btu/hr } \\
\end{array}$ & & 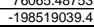 & - & 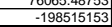 & & 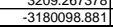 & $\begin{array}{l}3209.2601378 \\
3317910.723 \\
\end{array}$ & 3179910.723 & & 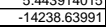 & 1443914015 & 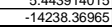 & 20170.090982.1 & & 2017090302.1 \\
\hline
\end{tabular}

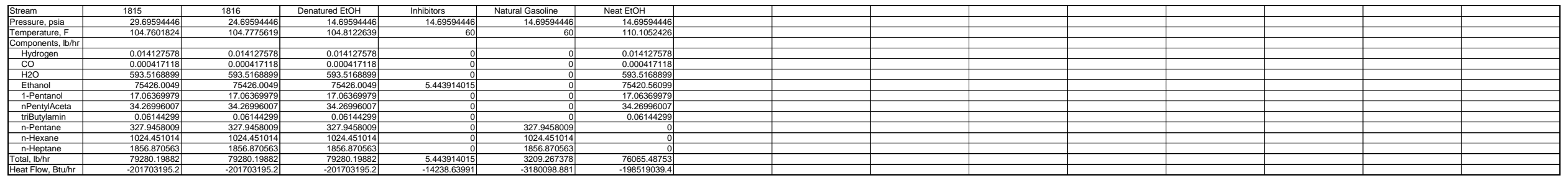


DE-FG36-03G013010

ZeaChem, Inc.

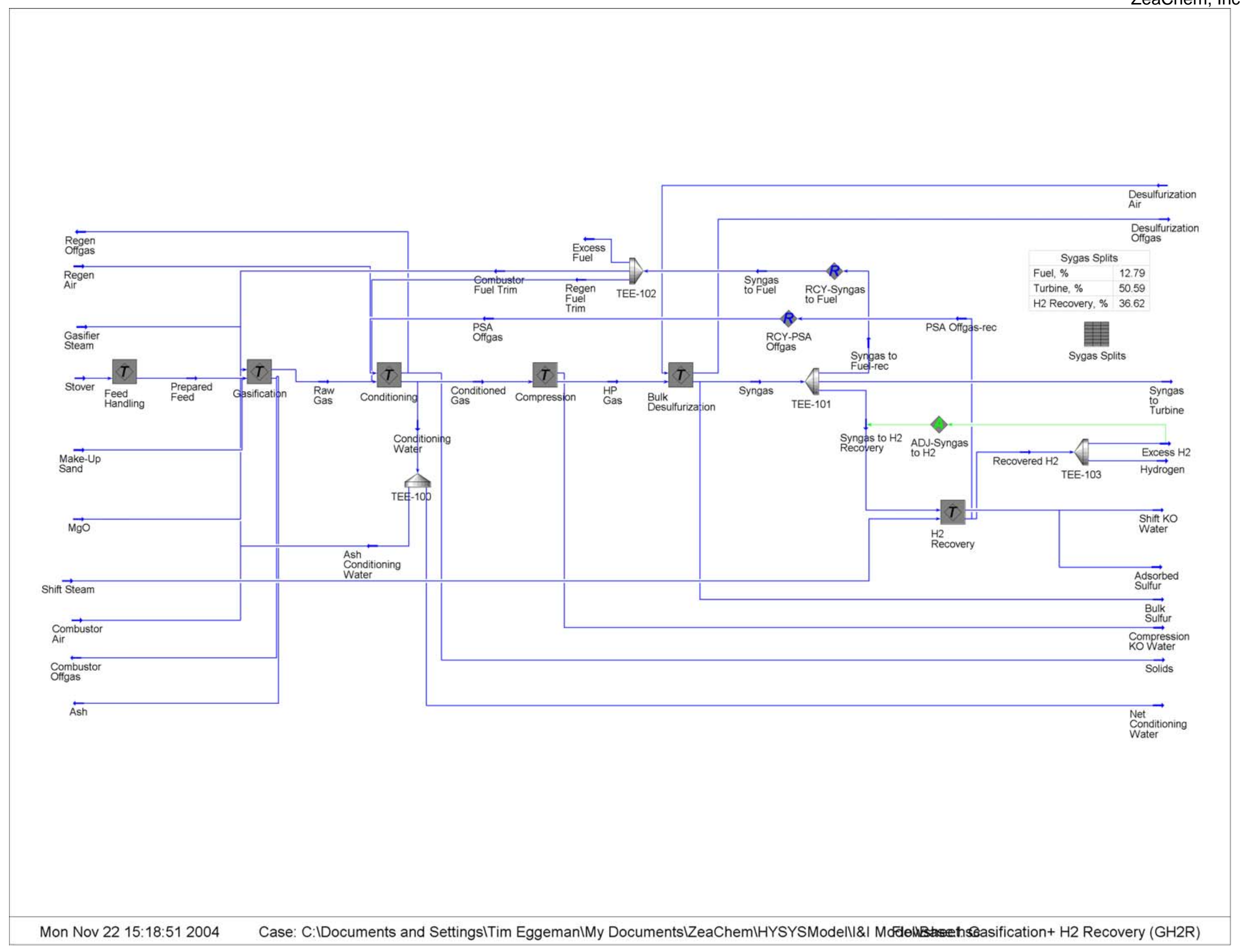


DE-FG36-03G013010

Flowsheet: Gasification + H2 Recovery (GH2R)

ZeaChem, Inc.

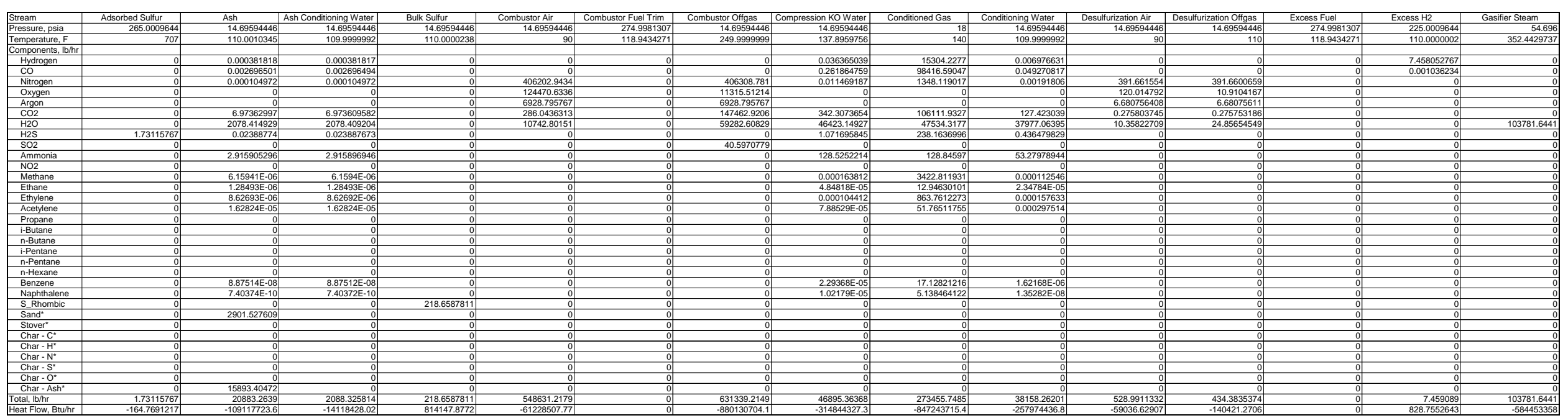

\begin{tabular}{|c|c|c|c|c|c|c|c|c|c|c|c|c|c|c|c|}
\hline 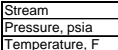 & $\begin{array}{l}\text { HP Gas } \\
285.0009644 \\
110\end{array}$ & \begin{tabular}{|c|} 
Hydrogen \\
25.0009644 \\
10.0000002
\end{tabular} & \begin{tabular}{c|} 
Make-Up Sand \\
60.0031759 \\
623
\end{tabular} & $\begin{array}{ll}\mathrm{MgO} \\
60.00317599 \\
\end{array}$ & \begin{tabular}{|c|} 
\\
3 \\
4
\end{tabular} & \begin{tabular}{|r|} 
PSA Offgas \\
\\
110
\end{tabular} & $\begin{aligned} \text { PSA Offgas-rec } & 25 \\
110 & \end{aligned}$ & $\begin{array}{r}\text { Prepared Feed } \\
14.6554446 \\
60.00038159 \\
\end{array}$ & \begin{tabular}{|r|} 
Raw Gas \\
1443.742683 \\
1
\end{tabular} & $\begin{array}{r}\text { Recovered H2 } \\
25.0009644 \\
110.0000000\end{array}$ & $\begin{array}{r}\text { Regen Air } \\
14.69594446 \\
90\end{array}$ & $\begin{array}{c}\text { Regen Fuel Trim } \\
271.9981307 \\
14899434271\end{array}$ & \begin{tabular}{|c|} 
Regen Offgas \\
14.6959446 \\
24999999998 \\
\end{tabular} & $\begin{array}{r}\text { Shift KO Water } \\
14.6959446 \\
110.3166349\end{array}$ & \begin{tabular}{r|} 
Shift Steam \\
304.696 \\
651.9141016
\end{tabular} \\
\hline \begin{tabular}{|l} 
Components, iblur \\
Hodrogen
\end{tabular} & 15304.19134 & 6766.499674 & & & 0.006594814 & 1195.40422 & 1195.404305 & & & & & & & 0.052881953 & \\
\hline \begin{tabular}{|l|} 
Co \\
Nitrogen \\
\end{tabular} & $\begin{array}{l}98416.32865 \\
1348.1075499 \\
\end{array}$ & 0.940148069 & & & $\begin{array}{l}0.046574323 \\
0.001813039 \\
\end{array}$ & $\begin{array}{l}3187.383875 \\
493.0979001 \\
\end{array}$ & $\begin{array}{l}3187.383568 \\
439.677288 \\
\end{array}$ & & 82512.51202 & 0.941184303 & & $\frac{12588.48719}{1.72 .4774112}$ & 7999 & & \\
\hline \begin{tabular}{|l} 
Oxygen \\
Argon \\
\end{tabular} & & & & & & \begin{tabular}{|l|l|}
$5.99614 E-06$ \\
$8.922111-08$ \\
\end{tabular} & \begin{tabular}{|l|l|}
$5.96914 E-06$ \\
$8.952111-08$ \\
\end{tabular} & & & & $\begin{array}{l}466617.54628 \\
25590.077399 \\
\end{array}$ & $\begin{array}{l}2.422226-06 \\
3.880202-08 \\
\end{array}$ & $\begin{array}{l}4237.900932 \\
255550.1738 \\
\end{array}$ & \begin{tabular}{|l|l|l|l}
$1.2439 E-06$ \\
$1.556577-08$
\end{tabular} & \\
\hline & $\begin{array}{l}1057769.6253 \\
1111.168312 \\
\end{array}$ & & & & $\begin{array}{l}\frac{1202.49942944}{358989.55474} \\
\end{array}$ & $\begin{array}{l}90222.921755 \\
611.5263374 \\
\end{array}$ & $\begin{array}{l}90222.962673 \\
611.5192468 \\
\end{array}$ & 46016.10021 & $\begin{array}{l}\frac{405593.256}{14997.744} \\
\end{array}$ & & $\begin{array}{l}1077.1309098 \\
023.463465 \\
\end{array}$ & $\begin{array}{l}13529.0 .079 \\
155.9903365 \\
\end{array}$ & $\begin{array}{l}134771.0 .075 \\
37349.69699 \\
\end{array}$ & $\begin{array}{l}128.50431449 \\
24619.82758 \\
\end{array}$ & 45914.91934 \\
\hline \begin{tabular}{|l|} 
Hos \\
SO2
\end{tabular} & 0 & & & & $\begin{array}{l}0.412592156 \\
\end{array}$ & & $a_{0}$ & & $\begin{array}{l}238.6001794 \\
0\end{array}$ & & & 0.604633276 & $\begin{aligned} 0 \\
1.136712744 \\
\end{aligned}$ & & \\
\hline & 0.320748371 & & & & 50.36389249 & $6.586676=-07$ & $6.58625 E-070$ & & 1821.257595 & & & 0.0410284988 & & 0.117466249 & \\
\hline $\begin{array}{l}\text { Methane } \\
\text { SEhone }\end{array}$ & 3422.811769 & & & & 0.000106386 & 1253.52776 & 1253.527938 & & 17114.0602 & & & 437.8138044 & & 0.000214867 & \\
\hline \begin{tabular}{|l} 
Enane \\
Ethylene \\
\end{tabular} & 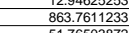 & & & & $\begin{array}{l}2.299335-05 \\
0.000149006 \\
\end{array}$ & $\begin{array}{l}\frac{4.742727591}{316.32601} \\
18537561\end{array}$ & 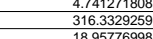 & & 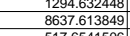 & & & 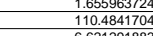 & & 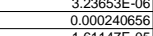 & \\
\hline \begin{tabular}{|l} 
Aceyene \\
Propen \\
ipouana
\end{tabular} & 51.16503872 & & & & 0.000281232 & & $\begin{aligned} 1.85365958 \\
0\end{aligned}$ & & 517.6541506 & & & 6.6212918835 & & $\begin{array}{r}1.61147 E-05 \\
0\end{array}$ & \\
\hline 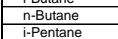 & & & & & & & & & & & & & & & \\
\hline \begin{tabular}{|l|} 
n-Pentane \\
$n$ \\
$n+$ Hexane
\end{tabular} & & & & & & & & & & & & & & & \\
\hline \begin{tabular}{|l|l|} 
Benzenen \\
Naphthalene \\
\end{tabular} & $\begin{array}{l}\frac{17.12818923}{55138459306} \\
\end{array}$ & & & & $\begin{array}{l}1.532938-06 \\
1.12778 E-08\end{array}$ & $\begin{array}{l}6.2727817738 \\
1.881844272\end{array}$ & $\frac{6.272815702}{1.8818436262}$ & & $\frac{\mid 1712.821378}{5533.864135}$ & & & $\begin{array}{l}2.190877471 \\
0.657262875\end{array}$ & & $\frac{6.22024 E-11}{2.55697-E-14}$ & \\
\hline \begin{tabular}{|l|l|} 
SRhombic \\
Sand*
\end{tabular} & & & $\begin{array}{r}0 \\
2994.589401 \\
\end{array}$ & $196.800816^{2}$ & & & & & \begin{tabular}{r|}
289.8626081 \\
\end{tabular} & & & & & & \\
\hline \begin{tabular}{|l} 
Stovert \\
Char $-\mathrm{C}^{*}$ \\
\end{tabular} & & & & & & & & $\begin{array}{r}244848.6001 \\
0\end{array}$ & \begin{tabular}{r|}
$0^{4.017110388}$ \\
\end{tabular} & & & & & & \\
\hline \begin{tabular}{|l} 
Charr- $\mathrm{H}^{*}$ \\
Chat
\end{tabular} & & & & & & & & & \begin{tabular}{|l}
0.53321212134 \\
0.010584999 \\
\end{tabular} & & & & & & \\
\hline $\begin{array}{l}\text { Char }-\mathrm{S}^{*} \\
\text { Char }-0^{+}\end{array}$ & & & & & & & & & & & & & & & \\
\hline 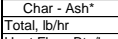 & $\begin{array}{r}226560.3848 \\
2\end{array}$ & $\begin{array}{r}6767.439822 \\
\end{array}$ & 2994.5894010 & $\frac{196.8008166^{2}}{4}$ & 36069.9362 & $\begin{array}{r}09316.6483 \\
97163\end{array}$ & 0 & $\begin{array}{r}15909.299711 \\
306774 \\
\end{array}$ & $\begin{array}{l}\frac{15.84999422}{312240.5518} \\
\end{array}$ & 6774.898911 & $\begin{array}{r}0 \\
205476.9102 \\
\end{array}$ & $\underset{28963.60997}{0}$ & 331754.7004 & 24748.54513 & $\begin{array}{l}14.91934 \\
919\end{array}$ \\
\hline Fow, Btwhre & & $\begin{array}{l}751908.3602 \\
\end{array}$ & & & & & & & & & & 7466 & & 6 & 526145426 \\
\hline
\end{tabular}


DE-FG36-03GO13010

ZeaChem, Inc.

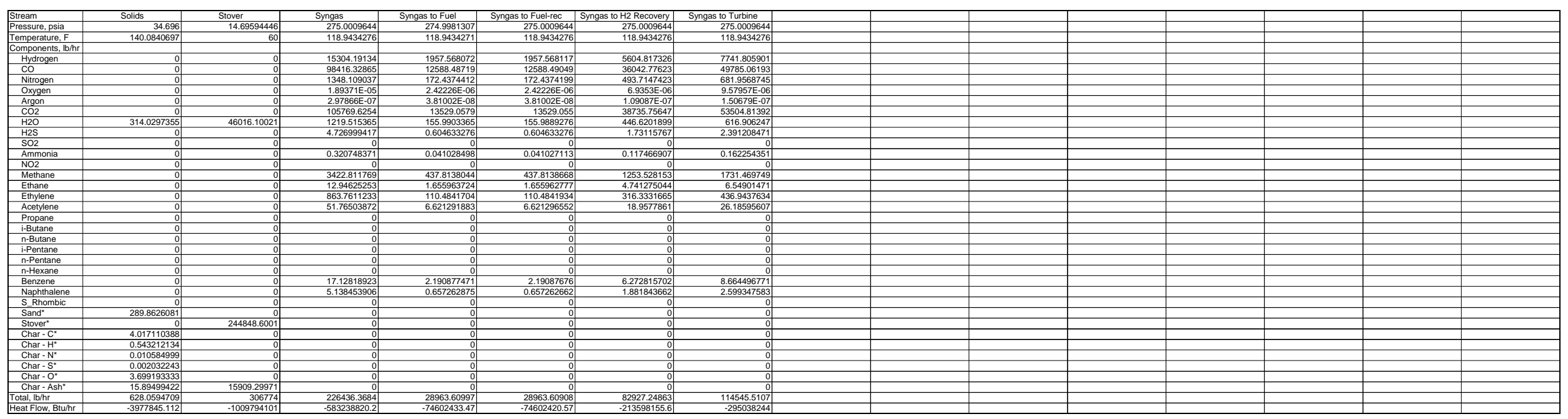




\section{Stover $\underset{X-2000}{\longrightarrow}$ Prepared Feed}

\section{Power Calcs}

BD Stover, metric ton/d 2839

Power, $\mathrm{Hp} /($ metric ton/d) $\quad 0.75$

HP.X-2000, Hp 2129

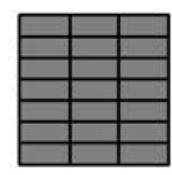

Power

Calcs 
DE-FG36-03G013010

ZeaChem, Inc.

Flowsheet: Feed Handling (HAND)

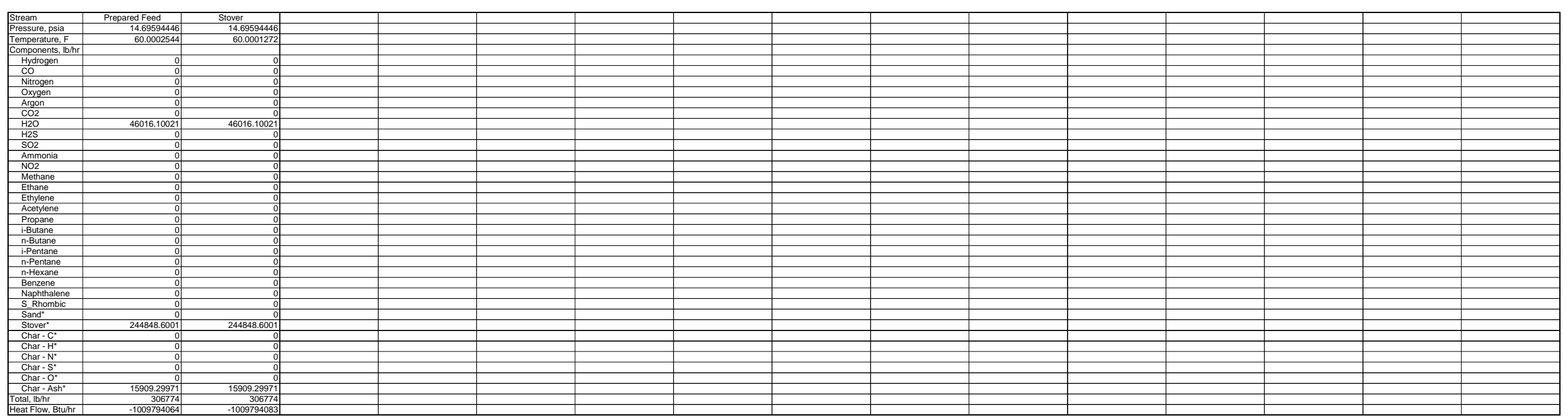


DE-FG36-03G013010

ZeaChem, Inc.

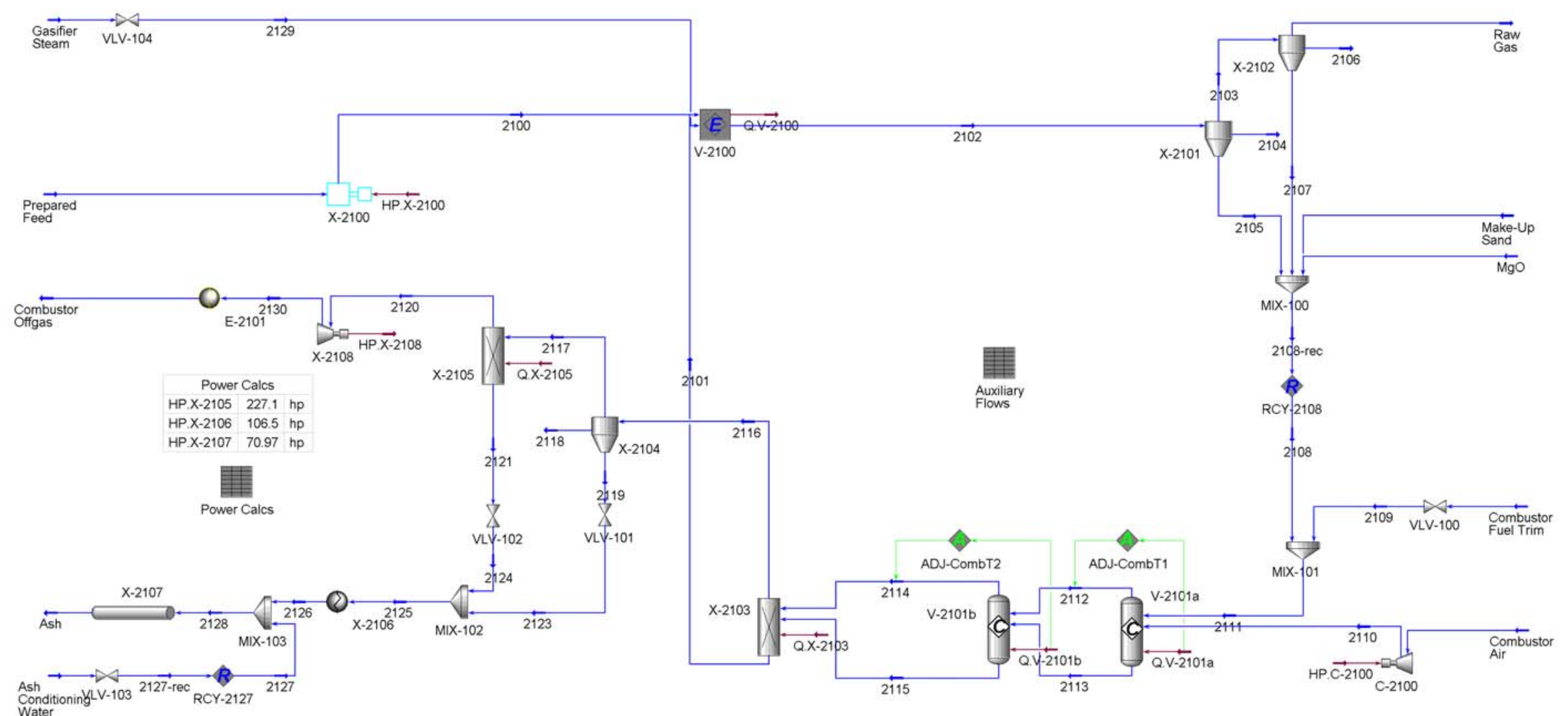


DE-FG36-03G013010

Flowsheet: Gasification (GASI)

ZeaChem, Inc.

\begin{tabular}{|c|c|c|c|c|c|c|c|c|c|c|c|c|c|c|c|}
\hline $\begin{array}{l}\text { Stream } \\
\text { Pressure, psia }\end{array}$ & 2100 & 2101 & 2102 & 2103 & 2104 & 2105 & 2106 & 2107 & 2108 & 2108 -rec & 2109 & 2110 & 2111 & 2112 & \begin{tabular}{|l|}
2113 \\
\end{tabular} \\
\hline 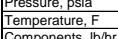 & $\begin{array}{r}60.060855007 \\
\end{array}$ & $\begin{array}{l}1848.510958 \\
\end{array}$ & $\begin{array}{r}1443.742685 \\
\end{array}$ & $\begin{array}{l}2344.742655 \\
\end{array}$ & $\begin{array}{l}1443.742685 \\
\end{array}$ & $\begin{array}{l}1443.742685 \\
\end{array}$ & $\begin{array}{l}1443.742685 \\
\end{array}$ & $\begin{array}{r}1443.742685 \\
\end{array}$ & $\begin{array}{r}1442.561622 \\
\end{array}$ & $\begin{array}{l}1442.561622 \\
.\end{array}$ & $\begin{aligned} 114.0416063 \\
\end{aligned}$ & $\begin{array}{r}178.383377 \\
\end{array}$ & $\begin{array}{l}23 \\
1442.561626 \\
\end{array}$ & $\begin{array}{r}23 \\
1848.513545 \\
\end{array}$ & $\begin{array}{r}23 \\
1848.513545 \\
\end{array}$ \\
\hline 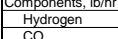 & & & $\begin{array}{l}2547.905306 \\
8251251202 \\
\end{array}$ & $\begin{array}{l}2547.905306 \\
2027.1502\end{array}$ & & & & & & & & & & 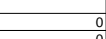 & 0 \\
\hline \begin{tabular}{|l} 
Nitrogen \\
Oxygen \\
\end{tabular} & & & 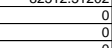 & & & & & & & & & 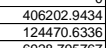 & & $\begin{array}{l}406308.781 \\
113255.51214 \\
12514\end{array}$ & \\
\hline 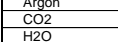 & 46016.1002 & & $\begin{array}{r}40593.2565 \\
1499777.743 \\
\end{array}$ & $\frac{40593.2565}{149797.743}$ & & & & & & & & 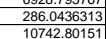 & & 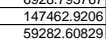 & \\
\hline \begin{tabular}{|l|l|}
$\mathrm{H} 2 \mathrm{~S}$ \\
$\mathrm{SOO}$ \\
\end{tabular} & 0 & & 238.6001794 & 238.6001794 & & & & & & & & & & $\begin{array}{r}0 \\
40.597079\end{array}$ & \\
\hline \begin{tabular}{|l} 
Ammonia \\
NO2 \\
\end{tabular} & & & $\begin{array}{r}1821.257595 \\
0\end{array}$ & \begin{tabular}{r|}
1821.257595 \\
0
\end{tabular} & & & & & & & & & & & \\
\hline \begin{tabular}{|l} 
Methane \\
Ethane \\
Ethluene \\
\end{tabular} & & & 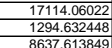 & 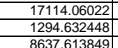 & & & & & & & & & & & \\
\hline \begin{tabular}{|l} 
Aceylene \\
Propane \\
\end{tabular} & & & $\begin{array}{l}517.6541506 \\
0\end{array}$ & $\begin{array}{l}517.6541506 \\
\end{array}$ & & & $=$ & & & & & & & & \\
\hline \begin{tabular}{|l|} 
i-Butane \\
n-Butane \\
\end{tabular} & & & & & & & 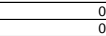 & & & & & & & & \\
\hline \begin{tabular}{|l|} 
i-Pertane \\
n-Pentane \\
\end{tabular} & & & & & & & & & & & & & & & \\
\hline \begin{tabular}{|l} 
n-Hexane \\
Benzene
\end{tabular} & & & $\begin{array}{r}0 \\
1712821378 \\
\end{array}$ & $\begin{array}{r}0 \\
821378 \\
\end{array}$ & & & & & & & & & & & \\
\hline \begin{tabular}{|l|} 
Naphhthalene \\
S R Rhombic \\
\end{tabular} & & & $\begin{array}{r}5138.464135 \\
0\end{array}$ & 5138.464135 & & & & & & & & & & & \\
\hline \begin{tabular}{|l|l|} 
Sand \\
\end{tabular} & 248900 & 2898626.081 & 2898626.081 & 2898.626081 & & 2895727.455 & & 2608.763473 & 2901527.609 & 2901527.609 & & & 2901527.609 & & 2901527.609 \\
\hline \begin{tabular}{|l} 
Char $-\mathrm{C}^{*}$ \\
\end{tabular} & & & 40171.10388 & 40.17110388 & & 40130.93278 & & 36.15399349 & 40167.08677 & 40167.08677 & & & 40167.08677 & & \\
\hline \begin{tabular}{|l} 
narl- $\mathrm{H}^{*}$ \\
Char $\mathrm{N}^{*}$
\end{tabular} & & & $\begin{array}{l}5435.1213357 \\
105.849938 \\
\end{array}$ & & & $\begin{array}{l}5426.083210 \\
105.741438 \\
\end{array}$ & & 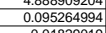 & $\begin{array}{l}105.8394088 \\
1058\end{array}$ & $\begin{array}{l}-435.5783125 \\
105.8394088 \\
\end{array}$ & & & $\begin{array}{l}5451.586125 \\
105.839088 \\
\end{array}$ & & \\
\hline 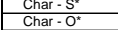 & & & $\begin{array}{r}\frac{20.3224243291}{36991.93333} \\
\end{array}$ & $\frac{0.020322433}{36.9919333}$ & & $\begin{array}{r}20.30211048 \\
36954.9414 \\
\end{array}$ & & $\begin{array}{r}0.01829019 \\
3.29274 \\
\end{array}$ & & $\begin{array}{r}320.322400067 \\
36988.23413 \\
\end{array}$ & & & $\begin{array}{l}20.0332040067 \\
36988.23414 \\
\end{array}$ & & 0 \\
\hline $\begin{array}{l}\text { Char }-\mathrm{Ash}^{*} \\
\text { oflat blhr }\end{array}$ & $\begin{array}{r}15909.29971 \\
306744 \\
3\end{array}$ & 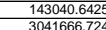 & $\begin{array}{l}158949.9422 \\
3452223877 \\
\end{array}$ & $\begin{array}{l}158.9499422 \\
3150686151 \\
3\end{array}$ & & $\begin{array}{l}158790.9922 \\
3137175.057 \\
\end{array}$ & & 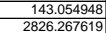 & 158934.0472 & 158934.0472 & & 54863. & 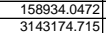 & & 559934.0472 \\
\hline Heat Flow, Btu/hr & -1009784109 & 16559000606055 & -18554043521 & -1007992706 & & -17546050816 & & -15807252.99 & -17581301323 & -17581301323 & & -49344664.53 & -17581301319 & -583842988.7 & T.04686020259 \\
\hline
\end{tabular}

\begin{tabular}{|c|c|c|c|c|c|c|c|c|c|c|c|c|c|c|c|}
\hline \begin{tabular}{|l} 
Strean \\
$\begin{array}{l}\text { Pressure, psia } \\
\text { Temperature F }\end{array}$
\end{tabular} & $\begin{array}{ll}2114 & 23 \\
1848.510958 & \end{array}$ & $\begin{array}{ll}2115 & 23 \\
1848.510995 & \end{array}$ & $\begin{array}{ll}2116 \quad 23 \\
1848.510598 \\
\end{array}$ & $\begin{array}{l}2117 \quad 23 \\
1848.510958\end{array}$ & $\begin{array}{ll}2118 & 25 \\
1848.510955 & \\
\end{array}$ & $\begin{array}{ll}2119 & 23 \\
1848.510958 & \end{array}$ & $\begin{array}{ll}2120 \quad 21 \\
1848.510958\end{array}$ & \begin{tabular}{|l|l|}
2121 & 21 \\
1848.510958
\end{tabular} & \begin{tabular}{r|}
$\frac{2123}{14.65594446}$ \\
1848.509927 \\
\end{tabular} & \begin{tabular}{c|}
2124 \\
14.6594446 \\
1848.487251 \\
\end{tabular} & $\begin{array}{l}\frac{2125}{14.6594446} \\
1848.507659 \\
\end{array}$ & \begin{tabular}{|l|}
2126 \\
14.69594446 \\
110 \\
\end{tabular} & \begin{tabular}{|l|}
2127 \\
14.65594446 \\
109.9999992 \\
\end{tabular} & \begin{tabular}{|c|} 
2127-rec \\
14.69594446 \\
109.9999993 \\
\end{tabular} & 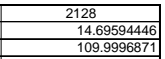 \\
\hline $\begin{array}{l}\text { Components, Ib/hr } \\
\text { Hydrogen }\end{array}$ & & & & & & & & & & & & & & & \\
\hline \begin{tabular}{|l|} 
CO \\
Nitrogen \\
\end{tabular} & 406308.781 & & 406308.781 & 406308.781 & & & 406308.781 & & & & & & \begin{tabular}{|c|}
0.02696501 \\
0.0000109472
\end{tabular} & 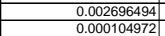 & $\begin{array}{l}0.0 .0202965501 \\
0.000104972 \\
\end{array}$ \\
\hline \begin{tabular}{|l|} 
Oxygen \\
Argon \\
$\mathrm{COO}$
\end{tabular} & 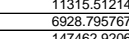 & & 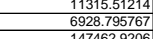 & $\begin{array}{l}131315.51214 \\
6928.75767 \\
1474629206\end{array}$ & & & $\begin{array}{l}\frac{11315.51214}{6928.795767} \\
\\
17630206\end{array}$ & & & & & & & & \\
\hline . & $\begin{array}{r}59282.60829 \\
0\end{array}$ & & $\begin{array}{r}59282.60829 \\
\end{array}$ & $\begin{array}{r}59282.608292 \\
\end{array}$ & & & 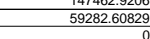 & & & & & & \begin{tabular}{|l|l|}
2078.44492929 \\
0.02388774
\end{tabular} & $\begin{array}{l}20078.409204 \\
0.23887673 \\
\end{array}$ & 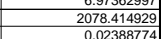 \\
\hline \begin{tabular}{|l} 
So2 \\
Ammonia \\
\end{tabular} & 40.5970779 & & $\begin{array}{r}40.5970779 \\
\end{array}$ & 40.5970779 & & & 40.5970779 & & & & & & 2.915905296 & 2.915896996 & 2.915905296 \\
\hline \begin{tabular}{|l} 
NO2 \\
Methane \\
\end{tabular} & & & & & & & & & & & & & $\begin{array}{r}\frac{0}{6.15941 E-06} \\
\end{array}$ & \begin{tabular}{r|}
$6.1594 \mathrm{o}-06$ \\
\end{tabular} & $\begin{aligned} 6.15941 E-06 \\
\end{aligned}$ \\
\hline \begin{tabular}{|l} 
Ehthane \\
Ehylene \\
\end{tabular} & & & & & & & & & & & & & 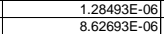 & 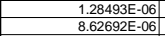 & $\begin{array}{l}1.284938-06 \\
8.62693 E-06 \\
\end{array}$ \\
\hline \begin{tabular}{|l|} 
Acetylene \\
Propane
\end{tabular} & & & & & & & & & & & & & $\begin{array}{l}1.62824 E-05 \\
\end{array}$ & $1.62824 \mathrm{E}-05$ & $1.62824 \mathrm{E}-05$ \\
\hline \begin{tabular}{|c|} 
i-Butane \\
in-Btane \\
n-Butane
\end{tabular} & & & & & & & & & & & & & & & \\
\hline 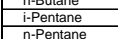 & & & & & & & & & & & & & & & \\
\hline 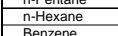 & & & & & & & & & & & & & & & \\
\hline \begin{tabular}{|l} 
Bezzene \\
Naphthalene \\
\end{tabular} & & & & & & & & & & & & & $\begin{array}{l}8.875514 E-08 \\
7.40374-10\end{array}$ & $\begin{array}{l}8.87512 E-0.8 \\
7.40372-10\end{array}$ & $\begin{array}{l}8.8 .85544-508 \\
7.703744-10 \\
\end{array}$ \\
\hline \begin{tabular}{|l|l|} 
SRhombic \\
Sand*
\end{tabular} & & $\frac{0}{2901527.609}$ & $\begin{array}{r}0 \\
2901.527609 \\
\end{array}$ & $\begin{array}{r}0 \\
290.1527609 \\
\end{array}$ & & $\begin{array}{r}0 \\
2611.374848 \\
\end{array}$ & & $\begin{array}{r}0 \\
290.1527609 \\
\end{array}$ & \begin{tabular}{r|}
2611.374848 \\
\end{tabular} & \begin{tabular}{r|}
290.1527609 \\
\end{tabular} & \begin{tabular}{r|}
2901.527609 \\
\end{tabular} & $\begin{array}{r}2901.527609 \\
2\end{array}$ & & & $\begin{array}{r}0 \\
2901.527609 \\
\end{array}$ \\
\hline \begin{tabular}{|l|} 
Stovert \\
Charr- $C^{*}$
\end{tabular} & & & & & & & & & & & & & & & \\
\hline \begin{tabular}{|l|l|} 
Char $\mathrm{H}^{*}$ \\
Char $-\mathrm{N}^{*}$
\end{tabular} & & & & & & & & & & & & & & & \\
\hline & & & & & & & & & & & & & & & \\
\hline \begin{tabular}{|c|} 
Char - Ash $^{*}$ \\
Total, lb/hr \\
\end{tabular} & $\underset{631339.2149}{0}$ & $\begin{array}{l}158934.0477^{2} \\
3060461.656 \\
\end{array}$ & $\begin{array}{r}15983.04427 \\
6551344.1473 \\
\end{array}$ & $\begin{array}{l}1589.340472 \\
633218.7082 \\
\end{array}$ & & $\begin{array}{l}14304.06425 \\
16915.43909 \\
\end{array}$ & 631339.2149 & $\begin{array}{l}1589.940442 \\
18979.437333 \\
\end{array}$ & $\begin{array}{l}14304.06425 \\
10995153909 \\
\end{array}$ & $\begin{array}{l}1589.3404722 \\
1877.493233\end{array}$ & $\begin{array}{l}155993.40472 \\
187744.93233 \\
\end{array}$ & $\begin{array}{l}15599.40472 \\
1879493233 \\
\end{array}$ & \begin{tabular}{r|}
2088.331568 \\
\end{tabular} & 2088.325814 & $\begin{array}{r}15893.40472 \\
20883.2639 \\
\end{array}$ \\
\hline at Flow, Btuhr & & & & 5925434338.4 & & $\frac{-78299360.36}{2}$ & & & & -8699941.929 & & 049096917 & & & 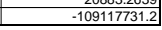 \\
\hline
\end{tabular}


DE-FG36-03GO13010

ZeaChem, Inc.

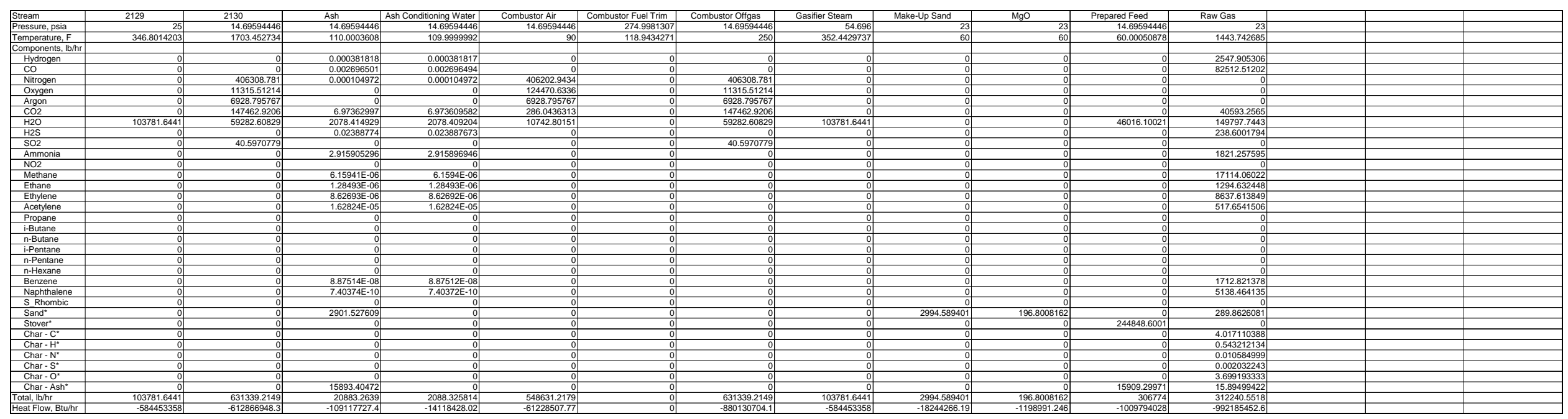


DE-FG36-03G013010

ZeaChem, Inc.

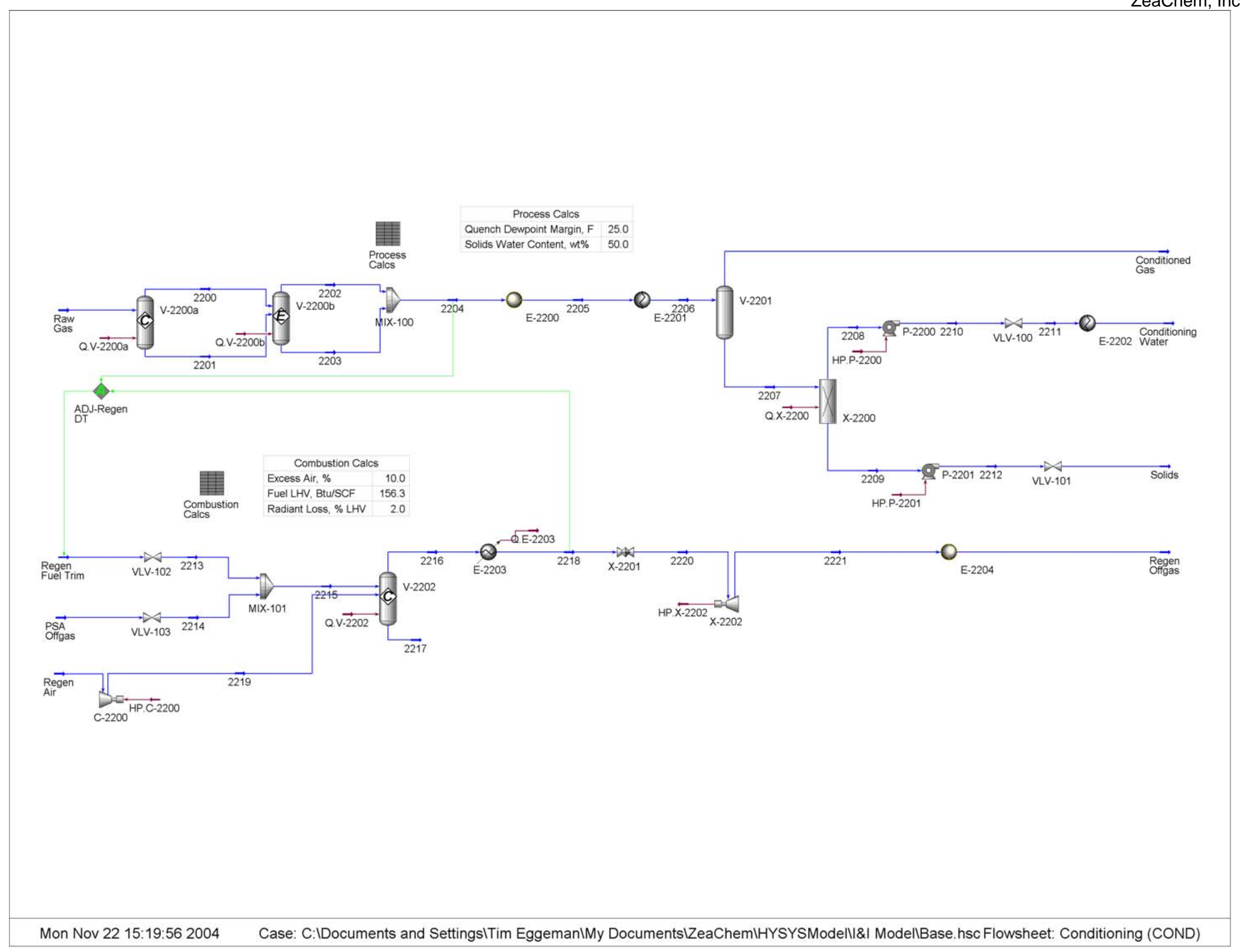


DE-FG36-03G013010

Flowsheet: Conditioning (COND)

ZeaChem, Inc.

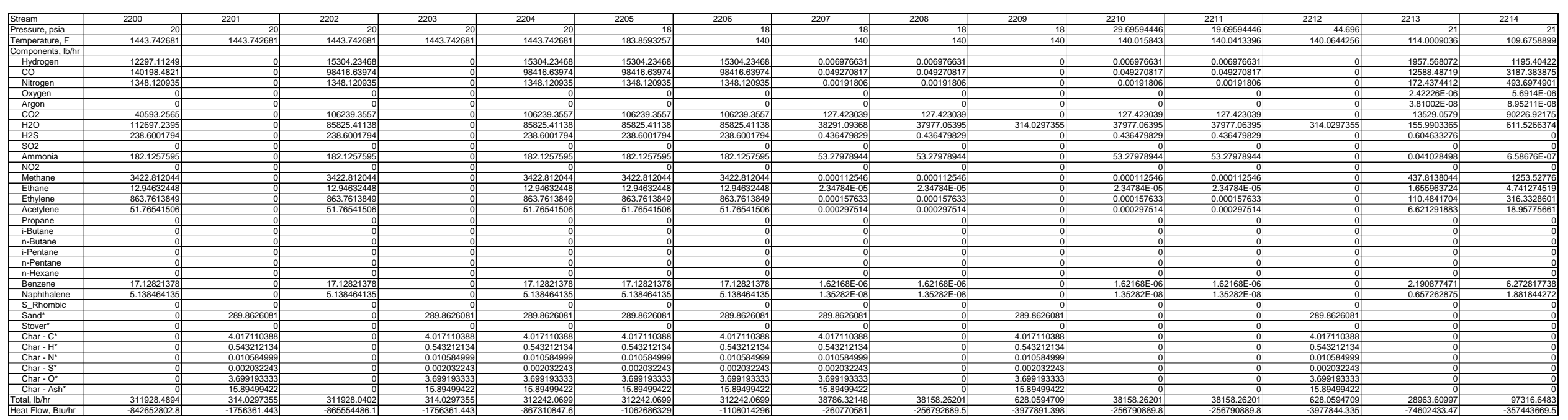

\begin{tabular}{|c|c|c|c|c|c|c|c|c|c|c|c|c|c|c|c|}
\hline $\begin{array}{l}\text { Stream } \\
\text { ressure, psia }\end{array}$ & 2215 & 2216 & 2217 & 2218 & 2219 & 2220 & $\frac{2221}{12.69594446}$ & Conditioned Gas & \begin{tabular}{|l|} 
Conditioning Water \\
14.69594446
\end{tabular} & PSA Offgas & Raw Gas & $\begin{array}{l}\text { Regen Air } \\
1469594446\end{array}$ & $\begin{array}{ll}\text { Regen Fuel Trim } \\
274.9981307\end{array}$ & \begin{tabular}{|c|} 
Regen Offgas \\
1.69595446
\end{tabular} & $\begin{array}{l}\text { Solds } \\
34.696 \\
34\end{array}$ \\
\hline $\begin{array}{l}\text { ressure, posia } \\
\text { eemperature, } F\end{array}$ & $\begin{array}{l}111.0373042 \\
\end{array}$ & 2755.4704 & 2755.4704 & $\begin{array}{r}1643.752531 \\
\end{array}$ & 159.3870902 & 1643.75257. & $\begin{array}{l}1536.276952 \\
153652 \\
\end{array}$ & & & & $\begin{array}{r}1443.742681 \\
\end{array}$ & & $\begin{array}{l}118.9434271 \\
\end{array}$ & & $\begin{array}{r}144.0850696 \\
\end{array}$ \\
\hline 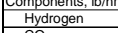 & 3152.972293 & & & & & & & 15304.2277 & 0.006976631 & 1195.40422 & 2547.905306 & & 1957.568072 & & \\
\hline Nitrogen & $\frac{15775.87106}{666.1349314}$ & $\begin{array}{l}152799.9208 \\
1528\end{array}$ & & $\begin{array}{l}152799.9208 \\
\end{array}$ & $\begin{array}{l}152133.7521 \\
\end{array}$ & 152799.920. & 152799.9208 & $\begin{array}{l}\frac{84466.59047}{1348.1190017} \\
\end{array}$ & $\frac{0.0997280817}{0.00191806}$ & $\begin{array}{l}\frac{31877.3838775}{493.697901} \\
\end{array}$ & & 152133.7521 & $\frac{15258.487919}{172.437412}$ & 152799.92 & \\
\hline $\begin{array}{l}\text { Oxygen } \\
\text { Arcon }\end{array}$ & 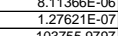 & 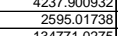 & & 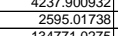 & $\begin{array}{l}26615.54628 \\
2595.017379 \\
\end{array}$ & 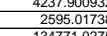 & 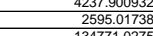 & & & 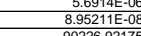 & 2015023565 & $\begin{array}{l}\frac{46615.54628}{2595.017379} \\
5979\end{array}$ & $\begin{array}{l}2.422626=-06 \\
3.81002-08 \\
\end{array}$ & 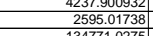 & \\
\hline $\begin{array}{ll}\frac{202}{H 2 O} \\
125\end{array}$ & 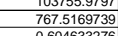 & $\begin{array}{l}13471.12259 \\
37349.69699 \\
\end{array}$ & & 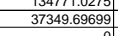 & $\begin{array}{l}100.13090968 \\
4023.463465 \\
\end{array}$ & $\begin{array}{l}\frac{13741.067}{37349.6969} \\
3\end{array}$ & $\begin{array}{l}134741.0279 \\
3739.69699 \\
\end{array}$ & 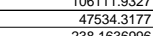 & 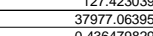 & $\begin{array}{l}9202.92615 \\
611.526374 \\
\end{array}$ & 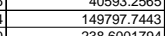 & 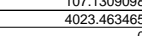 & 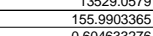 & $\begin{array}{l}\frac{13417.025}{37349.69699} \\
\end{array}$ & $314.02 \mathrm{C}$ \\
\hline $\begin{array}{ll}5 \mathrm{SO} 2 \\
\mathrm{Am}\end{array}$ & 0 & 1.136712744 & & 1.136712744 & & 1.13671274 & 1.136712744 & $\begin{array}{r}388.10309950 \\
128597\end{array}$ & 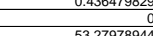 & 6596765 & 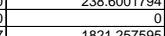 & & 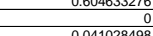 & 1.136712744 & \\
\hline $\begin{array}{ll}\text { No2 } \\
\text { Methane }\end{array}$ & $\begin{array}{l}0.1691 .341564 \\
169\end{array}$ & & & & & & & 3422.81911 & 0.000112546 & 1253.52776 & 17114.06022 & & 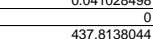 & & \\
\hline $\begin{array}{l}\text { 管地ane } \\
\text { Ethlene }\end{array}$ & $\frac{6.39723}{426.817}$ & & & & & & & & $\frac{2.044846-05}{20.345}$ & 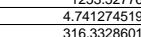 & 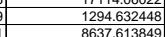 & & $\frac{1.659563}{1.65537}$ & & \\
\hline $\begin{array}{l}\text { Acentlene } \\
\text { Acente }\end{array}$ & 25.5790485 & & & & & & & 51.76511755 & 0.000297514 & 18.95775661 & 517.6541506 & & 6 & & \\
\hline \begin{tabular}{|l} 
Propane \\
i-Butane \\
\end{tabular} & 0 & & & & & & & & & & & & & & \\
\hline \begin{tabular}{|l} 
n-Butane \\
i-Pentane \\
\end{tabular} & $\begin{array}{l}0 \\
0 \\
\end{array}$ & & & & & & & & & & & & 0 & & \\
\hline \begin{tabular}{|c} 
nn-Pentane \\
$n$-Hexane
\end{tabular} & 0 & & & & & & & & 0 & 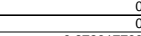 & 0 & & & & \\
\hline \begin{tabular}{|l} 
Bezzene \\
Naphthalene \\
\end{tabular} & $\begin{array}{r}8.466365921 \\
2.539107147 \\
\end{array}$ & & & & & & & $\begin{array}{l}\frac{17.128221216}{5.138464122} \\
\end{array}$ & $\begin{array}{l}\frac{1.62166 E-06}{1.35282 E-08} \\
\end{array}$ & $\begin{array}{l}6.2 .272817736 \\
1.881844272 \\
\end{array}$ & $\frac{17112.821378}{5138.464135}$ & & $\begin{array}{l}2.1900774711 \\
0.657262875 \\
\end{array}$ & & \\
\hline $\begin{array}{l}\text { S-Knombicic } \\
\text { Sand }\end{array}$ & & & & & & & & & & & $\begin{array}{r}289.8626081 \\
\end{array}$ & & & & 289.86266 \\
\hline & & & & & & & & & & & $\begin{array}{r}4.017110388 \\
\end{array}$ & & & & \\
\hline $\begin{array}{l}\frac{C h a r a r}{C^{*}} \\
\text { Char } N^{*}\end{array}$ & & & & & & & & & & & 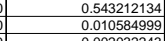 & & & & 0.0105849999 \\
\hline$\frac{\text { Charl } \frac{S^{*}}{\text { Chat }-\mathrm{O}^{*}}}{y^{2}}$ & & & & & & & & & & & & & & & 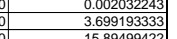 \\
\hline 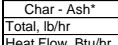 & $\begin{array}{r}126280.2583 \\
1.4302513\end{array}$ & $\begin{array}{r}331754.7004 \\
-34727765 \\
\end{array}$ & & $\frac{331754.7004}{-5.517092053}$ & $\begin{array}{l}205476.9102 \\
.1903290961 \\
\end{array}$ & $\begin{array}{l}331754,700 \\
.58902025\end{array}$ & $\frac{331754.7004}{5.59347909}$ & $\frac{273455.7485}{-8732735}$ & $\frac{38158.26201}{2.2572019}$ & 997316.6483 & 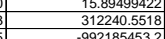 & $\frac{205476.9102}{2029369652}$ & $\begin{array}{l}\frac{28963.609977}{-763232347} \\
\end{array}$ & 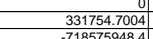 & 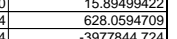 \\
\hline
\end{tabular}


DE-FG36-03G013010

ZeaChem, Inc.

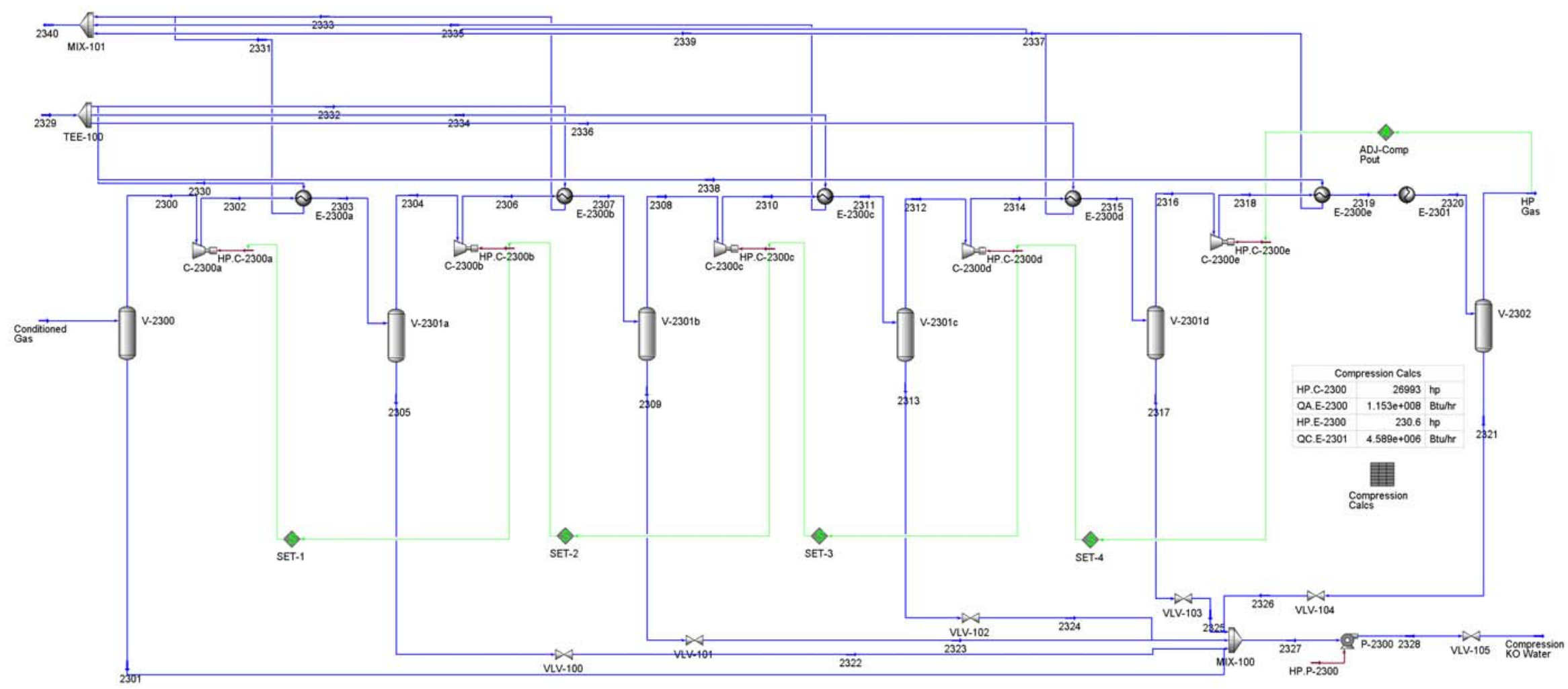


DE-FG36-03G013010

Flowsheet: Compression (COMP)

ZeaChem, Inc.

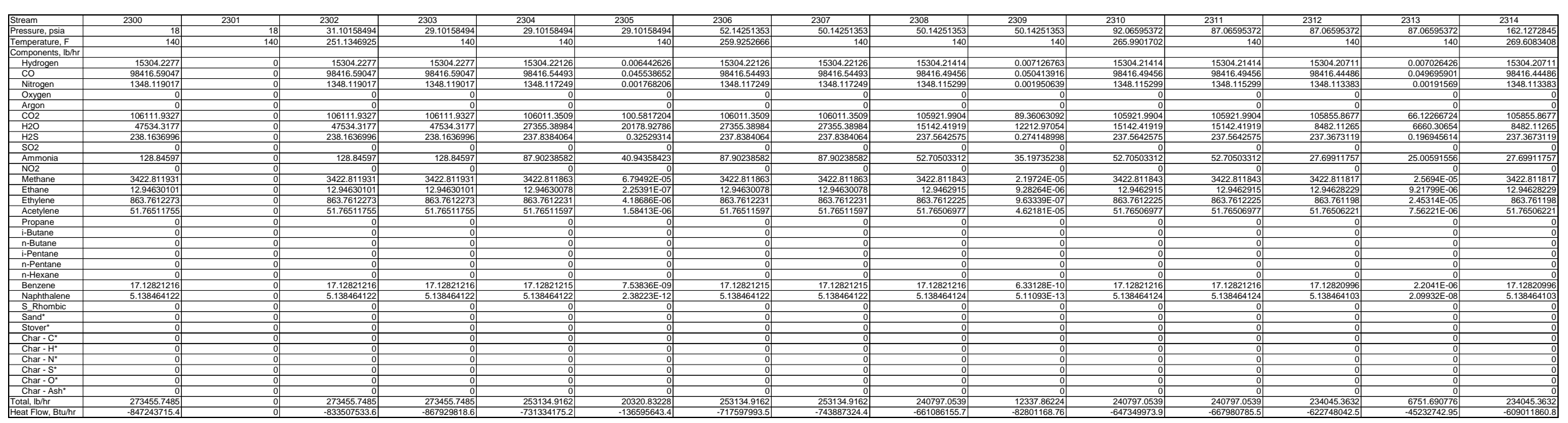

\begin{tabular}{|c|c|c|c|c|c|c|c|c|c|c|c|c|c|c|c|}
\hline $\begin{array}{l}\text { Stream } \\
\text { Pressure, psie }\end{array}$ & $\frac{2315}{157.1272845}$ & $\begin{array}{l}2316 \\
157.1272845\end{array}$ & $\frac{2317}{157.1272845}$ & $\frac{2318}{295.0009644}$ & $\frac{2319}{230.0009644}$ & $\frac{2320}{235.0009644}$ & $\frac{2321}{225.0009644}$ & $\begin{array}{ll}322 & 18 \\
\end{array}$ & \begin{tabular}{|ll}
2323 & 18 \\
\end{tabular} & $\begin{array}{ll}2324 & 18 \\
\end{array}$ & $\begin{array}{ll}2325 & 18 \\
\end{array}$ & 2326 & 2327 & $\frac{2328}{24.69594446}$ & $\frac{2329}{14.76812681}$ \\
\hline 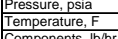 & & & & & & & & 140.0286465 & 140.0823908 & 140.1656076 & 140.2795636 & 110.5885511 & 137.8680841 & & $\begin{array}{r}4.1 .681-6801 \\
90 \\
\end{array}$ \\
\hline $\begin{array}{c}\text { Components, bihthr } \\
\text { Hydrogen }\end{array}$ & 15304.20711 & 15304.19957 & 0.007545202 & 15304.19957 & 15304.19957 & 15304.19957 & 0.008224022 & 0.006442626 & 0.007126763 & 0.007026426 & 0.007545202 & 0.008224022 & 0.036365039 & 0.036365039 & \\
\hline \begin{tabular}{|l|} 
Co \\
Nitrogen \\
\end{tabular} & \begin{tabular}{|l}
988146.44486 \\
1348.113383 \\
\end{tabular} & $\begin{array}{l}98416.39167 \\
1348.111338 \\
\end{array}$ & $\begin{array}{l}0.05131967 \pi \\
0.02020509\end{array}$ & 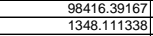 & $\begin{array}{l}98416.39167 \\
1348.111338 \\
\end{array}$ & $\begin{array}{l}98416.39167 \\
344.111338 \\
\end{array}$ & $\begin{array}{l}0.06301952 \\
0.003789561 \\
\end{array}$ & $\begin{array}{l}0.045558652 \\
0.001768206 \\
\end{array}$ & $\begin{array}{l}0.0 .050413916 \\
0.001550639 \\
\end{array}$ & \begin{tabular}{|l}
0.049695901 \\
0.00191569 \\
\end{tabular} & $\begin{array}{l}0.05319677 \\
0.00204509\end{array}$ & $\begin{array}{l}0.06301952 \\
0.03785616 \\
\end{array}$ & $\begin{array}{l}\frac{0.261864595}{0.011469187} \\
\end{array}$ & 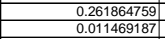 & 57946 \\
\hline \begin{tabular}{|l} 
Oxygen \\
Argon \\
$\mathrm{CO2} 2$ \\
\end{tabular} & & & 46.79244181 & 105809.0752 & 105809.0752 & 105809.0752 & 39.44990504 & 100.5817204 & 89360 & & 4679244181 & & & & 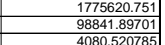 \\
\hline & $\begin{array}{r}135353.806 \\
2378.211265 \\
2377373119 \\
\end{array}$ & $\begin{array}{l}46520.2303228 \\
237.2253447\end{array}$ & 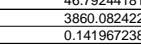 & $\begin{array}{l}46520.3030228 \\
237.2253447 \\
2328\end{array}$ & 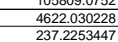 & 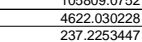 & 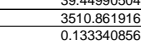 & 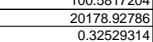 & 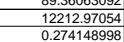 & 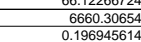 & 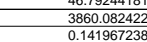 & 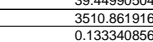 & 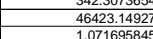 & 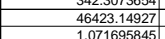 & 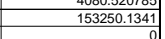 \\
\hline \begin{tabular}{|l|} 
SO2 \\
Ammonia
\end{tabular} & $\frac{0}{27.69911757}$ & $\begin{array}{r}0 \\
11.10953036 \\
\end{array}$ & $\underset{16.5995872}{\longrightarrow}$ & $\begin{array}{r}0 \\
11.10953036\end{array}$ & $\begin{array}{r}0 \\
11.10953036 \\
\end{array}$ & $\begin{array}{r}0 \\
11.10953036 \\
\end{array}$ & $\begin{array}{r}0 \\
10.78878199 \\
\end{array}$ & $\begin{array}{r}0 \\
40.94358423 \\
\end{array}$ & $\begin{array}{r}0 \\
35.19735238 \\
\end{array}$ & $\frac{0}{25.00591556}$ & $\frac{0}{16.5958572}$ & $\begin{array}{r}0 \\
10.78878199\end{array}$ & $\frac{}{128.5252214}$ & 1 & \\
\hline \begin{tabular}{|l|} 
No2 \\
Methane \\
\end{tabular} & $\underset{3422.811817}{0}$ & $\begin{array}{r}0 \\
3422.817977 \\
\end{array}$ & $\frac{1.98676-05}{\longrightarrow}$ & \begin{tabular}{r|}
3422.811797 \\
\end{tabular} & $\begin{array}{r}0 \\
3422.81797 \\
\end{array}$ & $\frac{0}{3422.81797}$ & $\begin{aligned} 0 \\
2.83285-05 \\
\end{aligned}$ & $\begin{aligned} 0 \\
6.79492 E-05 \\
6\end{aligned}$ & $2.19724 \mathrm{E}-0$ & $2.5694 E-05$ & $1.98676 \mathrm{E}-05$ & $2.83285 E-05$ & 3812 & 0.000163812 & \\
\hline \begin{tabular}{|l|} 
Ethane \\
Ethlyene \\
\end{tabular} & $\frac{12.94628229}{863.717198}$ & $\begin{array}{l}12.94625267 \\
863.71511525 \\
\end{array}$ & $\begin{array}{l}2.961115 E-0.05 \\
4.511505-0.95\end{array}$ & \begin{tabular}{|c|c|}
12.94625267 \\
863.7171525 \\
\end{tabular} & $\begin{array}{l}12.94625257 \\
863.7151525 \\
\end{array}$ & $\frac{12.94625267}{8836761525}$ & $\frac{1.42201 E-07}{2.921985-05}$ & $\begin{array}{l}2.25391 E-07 \\
4.18666-0606\end{array}$ & $\begin{array}{l}9.28264 E-06 \\
9.63393 E E-077\end{array}$ & $\begin{array}{l}\frac{9.21799 E-06}{2.44314 E-05} \\
\end{array}$ & $\begin{array}{l}2.96115 E-05 \\
4.515105 E-05 \\
\end{array}$ & $\frac{1.44201 E-07}{2.92189 E-05}$ & $\begin{array}{l}4.848186-05 \\
0.000104412 \\
\end{array}$ & \begin{tabular}{|c|c|}
$4.84818 E-05$ \\
0.0001014412
\end{tabular} & \\
\hline \begin{tabular}{|c|} 
Acetylene \\
Ceryen
\end{tabular} & 51.76506221 & 51.76504683 & $1.53818 \mathrm{E}-0.5$ & 51.76504683 & 51.76504683 & 51.76504683 & $8.10658 \mathrm{E}-06$ & $\begin{array}{l}1.580013 \mathrm{E}-06 \\
\end{array}$ & $4.62181 \mathrm{E}-05$ & $\begin{array}{l}2.56221 \mathrm{E}-06 \\
7.562\end{array}$ & $\begin{array}{l}4.538318 \mathrm{E}-05 \\
\end{array}$ & $8.10658 \mathrm{E}-06$ & $\begin{array}{l}0.0852929 \mathrm{E}-05 \\
\end{array}$ & $7.88529 E-05$ & \\
\hline \begin{tabular}{|l|} 
Propane \\
i-Butane \\
\end{tabular} & & & & & & & & & & & & & & & \\
\hline \begin{tabular}{|l|l}
$\mathrm{n}$ n-Butane \\
\end{tabular} & & & & & & & & & & & & & & & \\
\hline \begin{tabular}{|l} 
iterntane \\
n-P Pentane
\end{tabular} & & & & & & & & & & & & & & & \\
\hline \begin{tabular}{|l} 
n-terzane \\
Benzene \\
\end{tabular} & 17.12820996 & 17.12818924 & $2.071855-0.5$ & 17.12818924 & 17.12818924 & 17.12818924 & $6.07516 \mathrm{E}-09$ & $7.53836 \mathrm{E}-0.0$ & $6.33128 E-10$ & $2.2041 E-06$ & $2.07185 \mathrm{E}-\mathrm{I}$ & $6.07516 \mathrm{E}-09$ & $2.29368 \mathrm{E}-0.5$ & $\begin{array}{l}2.29368 E-05 \\
\end{array}$ & \\
\hline \begin{tabular}{|l|} 
Naphthalene \\
S Rhombic \\
\end{tabular} & 5.138464103 & 5.1384635 & & 5.1384635 & 5.13 & & $9.59418 \mathrm{E}-06$ & & 5.11 & & & $9.59418 E-06$ & & & \\
\hline 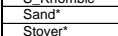 & & & & & & & & & & & & & & & \\
\hline 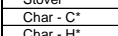 & & & & & & & & & & & & & & & \\
\hline \begin{tabular}{|l|l|} 
Char $-\mathbb{N}^{*}$ \\
Char $-\mathrm{S}^{*}$ \\
\end{tabular} & & & & & & & & & & & & & & & \\
\hline CCar- $-\mathrm{Ash}^{*}$ & & & & & & & & & & & & & & & \\
\hline \begin{tabular}{|l} 
Total, libhr \\
Heat Flow, Buthr
\end{tabular} & $\begin{array}{r}234045.3632 \\
-626829225\end{array}$ & $\begin{array}{r}230121.6938 \\
-6.000578018 .7\end{array}$ & $\frac{3923.66933}{-262521206.26}$ & 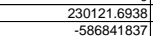 & $\begin{array}{l}230121.6938 \\
-6.62995330 .2 \\
\end{array}$ & $\begin{array}{l}230121.6938 \\
-6.67758766 .5 \\
\end{array}$ & $\begin{array}{l}3561.309053 \\
-23964869.9 \\
\end{array}$ & $\begin{array}{l}-20320.03228 \\
-1.36595643 .4 \\
\end{array}$ & $\frac{12337.86224}{-828011188.76}$ & $\frac{6751.690776}{-455237272.95}$ & $\frac{3923.66937}{-262512066.26}$ & 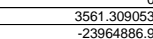 & $\frac{46895.36368}{-314865648.3}$ & $\begin{array}{l}\frac{468959.36368}{-3.4444372 .3} \\
\end{array}$ & $\begin{array}{l}\frac{7826432.205}{-8.8335662 .5} \\
\end{array}$ \\
\hline
\end{tabular}


DE-FG36-03G013010

ZeaChem, Inc.

\begin{tabular}{|c|c|c|c|c|c|c|c|c|c|c|c|c|c|c|c|}
\hline \begin{tabular}{|l|} 
Stream \\
Pressure, psia \\
Tremperature F \\
\end{tabular} & $\begin{array}{l}\frac{2330}{14.76812681} \\
00\end{array}$ & $\begin{array}{l}2331 \\
14.69594446 \\
15\end{array}$ & $\begin{array}{l}\frac{2332}{14.76812681} \\
90\end{array}$ & \begin{tabular}{|c|}
2333 \\
14.69594446 \\
\end{tabular} & $\begin{array}{l}2334 \\
14.76812681 \\
\end{array}$ & $\begin{array}{l}2335 \\
14.69594446 \\
\end{array}$ & $\begin{array}{l}2336 \\
14.76812681 \\
\end{array}$ & \begin{tabular}{|l|l|}
2337 \\
14.69594446 \\
\end{tabular} & $\begin{array}{l}2338 \\
14.76812681 \\
\end{array}$ & $\begin{array}{l}2339 \\
14.69594446 \\
\end{array}$ & $\begin{array}{l}2340 \\
14.69594446 \\
\end{array}$ & $\begin{array}{c}\text { Compression KO Water } \\
14.69594446\end{array}$ & $\begin{array}{c}\text { Conditioned Gas } \\
18\end{array}$ & $\begin{array}{c}\text { HP Gas } \\
285.0009644 \\
\end{array}$ & \\
\hline $\begin{array}{l}\text { Temperature, } F \\
\text { Components, } 1 \text { thir }\end{array}$ & & & & & & & & & & & & & & & \\
\hline \begin{tabular}{|l|l|l|l|l} 
Hydrogen \\
Co
\end{tabular} & & & $\begin{array}{c}0 \\
0 \\
0\end{array}$ & $\begin{array}{ll}0 \\
0\end{array}$ & & & & & & & & $\begin{array}{l}0.036365039 \\
0.261868459 \\
\end{array}$ & 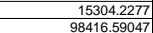 & $\begin{array}{l}15304.19134 \\
944616.32865 \\
\end{array}$ & \\
\hline $\begin{array}{l}\text { Nitrogen } \\
\text { Oxygen } \\
\end{array}$ & $\begin{array}{l}\frac{17279955.427}{530040.1727} \\
\end{array}$ & $\begin{array}{l}\frac{1779955.427}{530040.1727} \\
\end{array}$ & $\begin{array}{l}\frac{1321066.376}{404807.4281} \\
0.98\end{array}$ & $\begin{array}{l}\frac{13221066.366}{404807.4281} \\
\end{array}$ & $\begin{array}{l}\frac{11306719.859}{317676.6191} \\
\end{array}$ & $\begin{array}{l}\frac{10306719.859}{317676.6191} \\
\end{array}$ & $\begin{array}{l}8593411.18711 \\
27354.6954\end{array}$ & 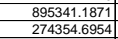 & $\begin{array}{l}811755.0533 \\
288741.8356\end{array}$ & \begin{tabular}{l|l}
817755.0533 \\
288741.38656
\end{tabular} & $\begin{array}{l}5799638.903 \\
175620.751 \\
\end{array}$ & $\begin{array}{r}0.011469187 \\
0\end{array}$ & $\begin{array}{r}1348.119017 \\
0\end{array}$ & $\begin{array}{r}1348.107549 \\
0\end{array}$ & \\
\hline $\begin{array}{l}\text { Argon } \\
\mathrm{CO} 2\end{array}$ & $\begin{array}{l}295505.27366 \\
218.075392 \\
\end{array}$ & $\begin{array}{l}29505.27366 \\
1218.075392 \\
\end{array}$ & $\begin{array}{l}22233.05443 \\
930.2803673 \\
\end{array}$ & 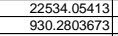 & $\frac{17688.82108}{730.066873}$ & $\frac{1768.82188}{7700.066873}$ & $\frac{15272.25518}{630.489386}$ & 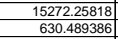 & $\begin{array}{l}\frac{13846.68996}{5716.689528} \\
\end{array}$ & $\begin{array}{l}13846.48996 \\
577.628528 \\
\end{array}$ & $\begin{array}{l}98841.199701 \\
4080.5250785 \\
\end{array}$ & 342.3073654 & 106111.9327 & 105769.6253 & \\
\hline $\begin{array}{ll}\mathrm{H} 20 \mathrm{O} \\
\mathrm{H} 2 \mathrm{~S} \\
\end{array}$ & $\begin{array}{l}45746.66494 \\
\end{array}$ & 45746.66494 & 34938.08721 & 34938.08721 & 27418.00829 & $\begin{aligned} 27418.00829 \\
\end{aligned}$ & $\begin{array}{r}23678.98316 \\
\end{array}$ & \begin{tabular}{r|}
23678.98316 \\
\end{tabular} & $\begin{array}{r}21466.3905 \\
0\end{array}$ & $\begin{array}{r}21468.3905 \\
\end{array}$ & $\begin{array}{l}153250.1341 \\
0\end{array}$ & $\begin{array}{l}\frac{46423.14}{1.071695} \\
1.09\end{array}$ & $\begin{array}{l}477534.3177 \\
238.1363996 \\
\end{array}$ & $\begin{array}{l}11111.168312 \\
237.0920038 \\
\end{array}$ & \\
\hline $\begin{array}{l}\text { So2 } \\
\text { Ammonia } \\
\end{array}$ & & & & & & & & & & & & $\begin{array}{l}0 \\
128.52525214 \\
\end{array}$ & 128.84597 & $\begin{array}{r}0 \\
0.32074371 \\
\end{array}$ & 71 \\
\hline \begin{tabular}{|l|} 
Methane \\
\end{tabular} & & & & & & & & & & & & 0.000163812 & 3422.811931 & 3422.811769 & \\
\hline \begin{tabular}{|l} 
Enalene \\
Ethylene \\
\end{tabular} & & & & & & & & & & & & $\begin{array}{l}\frac{4.838818-0.05}{0.000104412} \\
\end{array}$ & $\begin{array}{l}\frac{82.9435030101}{863.7612273} \\
\end{array}$ & $\begin{array}{l}12.94252533 \\
863.7611233 \\
\end{array}$ & \\
\hline \begin{tabular}{|l|} 
Propane \\
\end{tabular} & & & & & & & & & & & & & & $51.1650387 / 2$ & \\
\hline $\begin{array}{l}\text { n-Butane } \\
\text { i-Pentane }\end{array}$ & & & & & & & & & & & & & & & \\
\hline $\begin{array}{l}n \text { n-Pentane } \\
\text { n-thexane }\end{array}$ & & & & & & & & & & & & & & & \\
\hline \begin{tabular}{|l} 
hinexane \\
Benzen \\
Nonothatere \\
\end{tabular} & & & & & & & & & & & & $\begin{array}{l}2.29368-05 \\
1.0279-055 \\
\end{array}$ & $\frac{17.12821216}{5.13864122}$ & $\begin{array}{l}17.12818923 \\
5.13852006 \\
\end{array}$ & \\
\hline \begin{tabular}{|l} 
S Rhombic \\
Sand*
\end{tabular} & & & & & & & & & & & & & (1) & 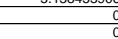 & \\
\hline \begin{tabular}{|l|l|} 
Stovert \\
Shar \\
Chat
\end{tabular} & & & & & & & & & & & & & & & \\
\hline \begin{tabular}{|l|} 
Charar $-\mathrm{H}^{*}$ \\
Char $\mathrm{N}^{*}$
\end{tabular} & & & & of & & & & & & & & & & $\frac{0}{0}$ & \\
\hline $\begin{array}{l}\text { Char }-S^{*} \\
\text { Char }-0^{*}\end{array}$ & & & & & & & & & & & & & & & \\
\hline 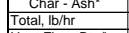 & 2336266.613 & 2336266.613 & $\begin{array}{r}1784276.226 \\
\end{array}$ & 1784276.226 & $\begin{array}{r}0 \\
1400228.355 \\
\end{array}$ & 1400228.355 & 1209277.613 & 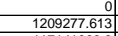 & 10963383.398 & 1096383.398 & 432 & 468995.36368 & 5.7485 & 226560.3848 & \\
\hline Heat Flow, Buthrs & -260734467.1 & -226312170 & -1991306559.2 & $-1.172841328 .3 \mid$ & -156269777.5 & -1356389935.9 & -1349559063.4 & $-\frac{-117141699.2}{-2}$ & -122359725.3 & -106205732.1 & -7581398965.6 & -314844327.3 & -847243715.4 & -5883619880.6 & \\
\hline
\end{tabular}




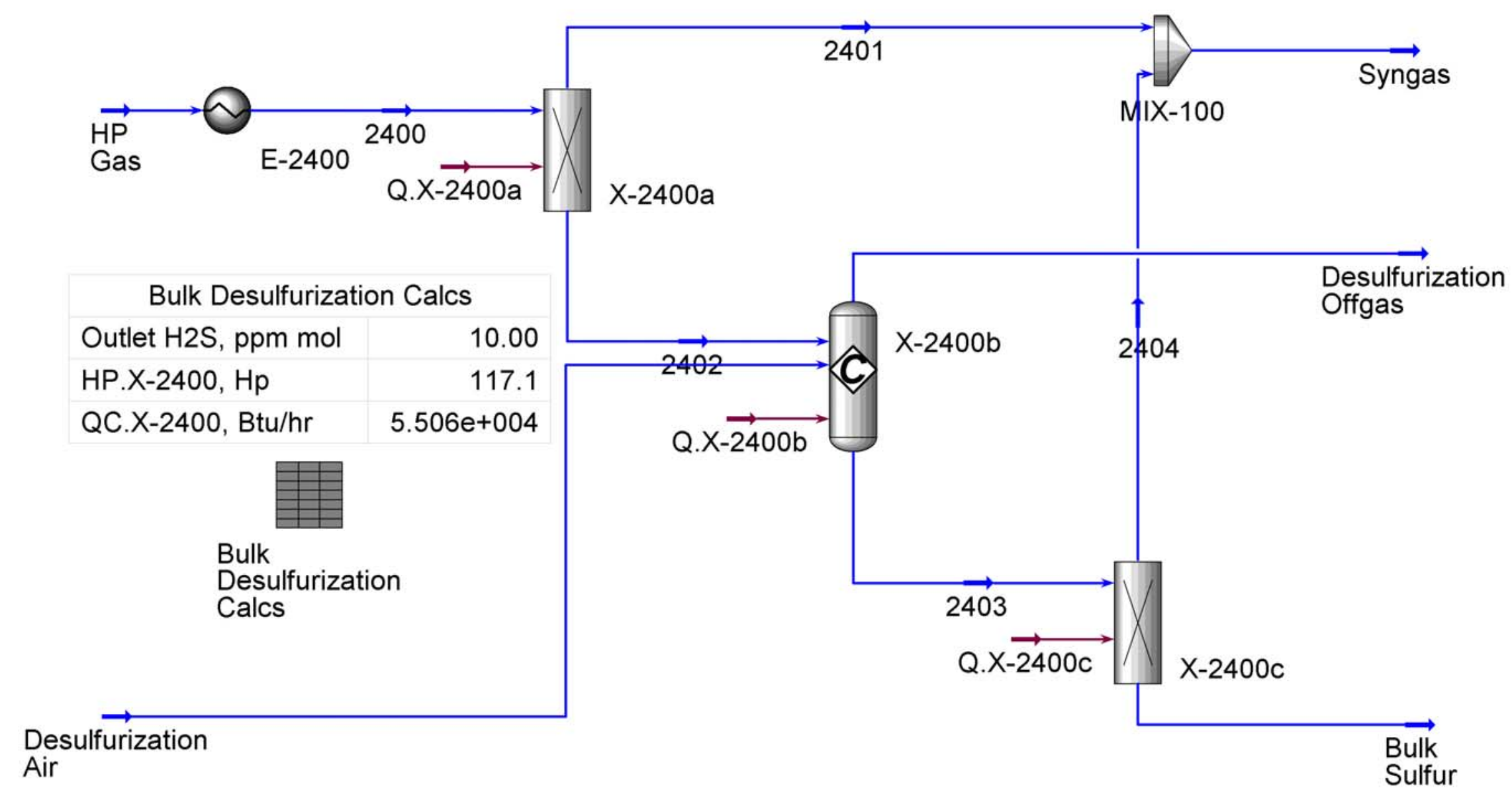


DE-FG36-03G013010

ZeaChem, Inc.

Flowsheet: Bulk Desulfurization (DESU)

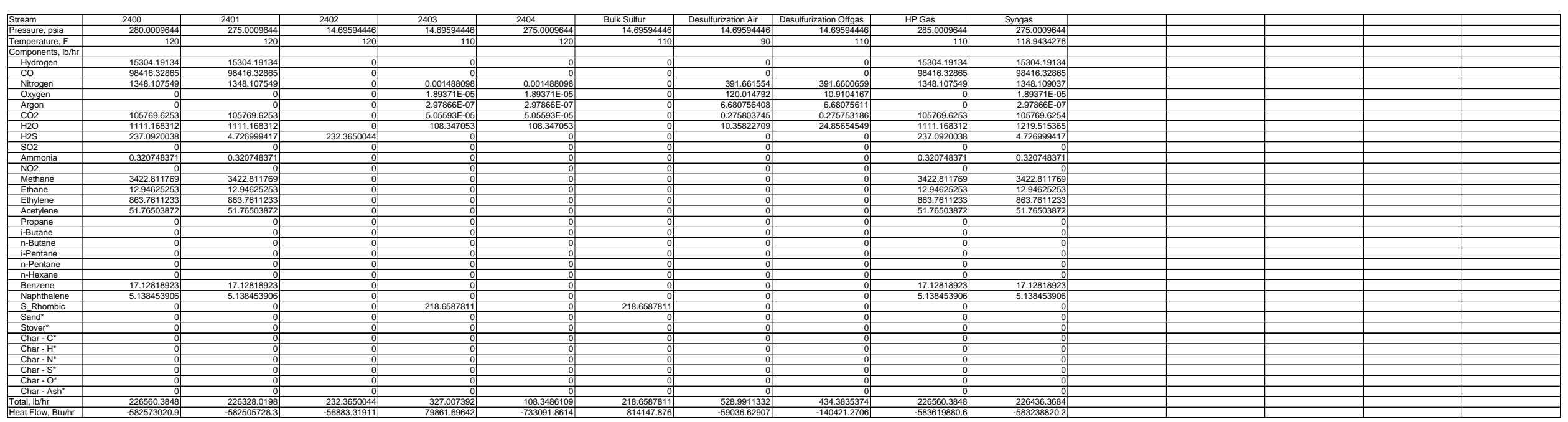


DE-FG36-03G013010

ZeaChem, Inc.

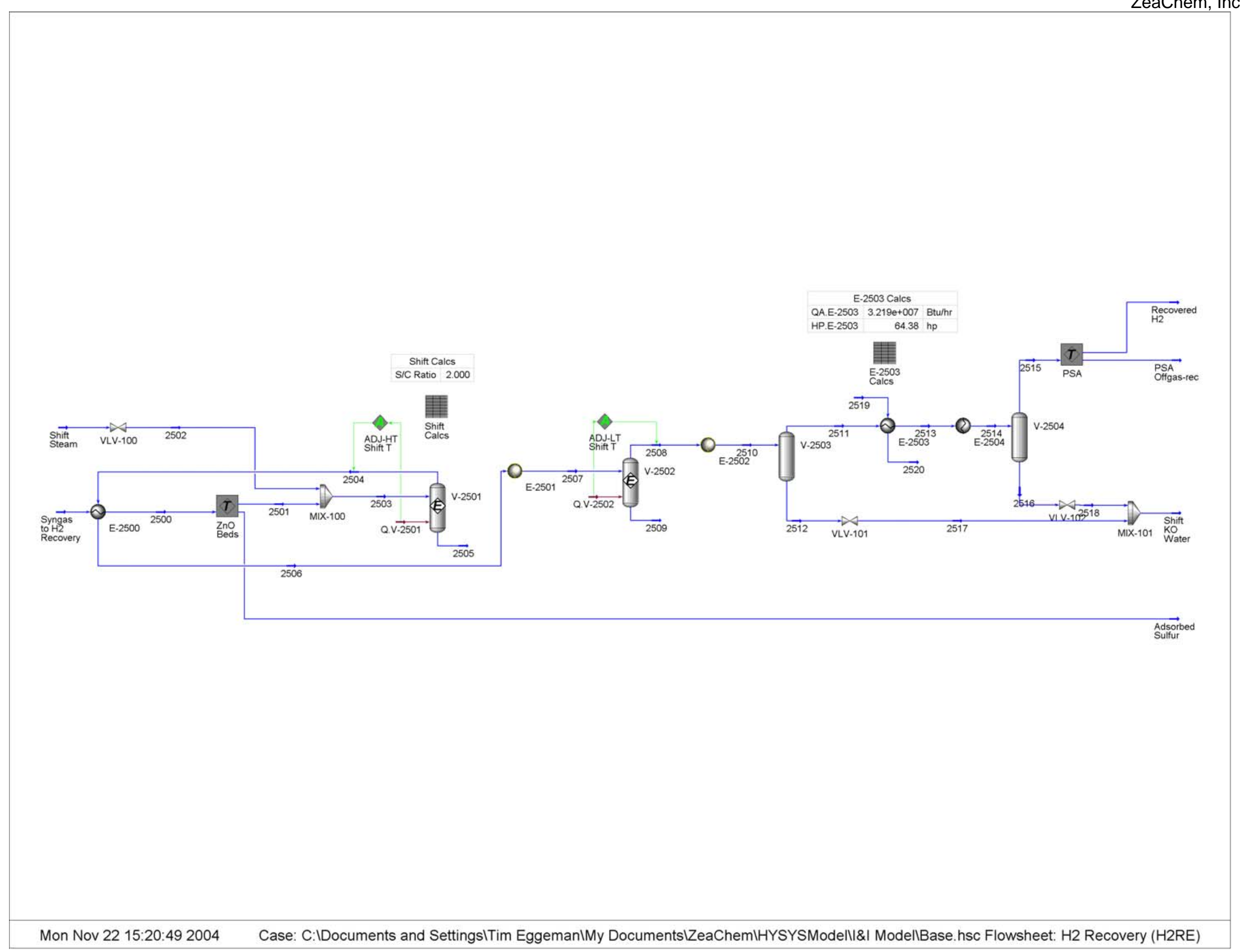


DE-FG36-03G013010

Flowsheet: H2 Recovery (H2RE)

ZeaChem, Inc.

\begin{tabular}{|c|c|c|c|c|c|c|c|c|c|c|c|c|c|c|c|}
\hline $\begin{array}{l}\text { Stream } \\
\text { Pressure, psia } \\
\text { Tosura }\end{array}$ & $\begin{array}{l}2500 \\
270.0009644 \\
\end{array}$ & \begin{tabular}{|c|}
2501 \\
265.0009644 \\
\end{tabular} & $\begin{array}{l}2502 \\
265.0009644 \\
647773736 \\
\end{array}$ & \begin{tabular}{|c|}
2503 \\
265.0009644 \\
681090954 \\
\end{tabular} & $\begin{array}{l}2504 \\
260.0009644 \\
20.002511 \\
\end{array}$ & \begin{tabular}{c|}
2505 \\
260.0009644 \\
6006541
\end{tabular} & $\begin{array}{c}2506 \\
257.5009644 \\
\end{array}$ & \begin{tabular}{|l|l|}
2507 \\
255.0009644 \\
3922 \\
\end{tabular} & \begin{tabular}{|c|}
2508 \\
250.0009644 \\
51817099
\end{tabular} & \begin{tabular}{|l|}
2509 \\
250.0009644 \\
50.11209 \\
\end{tabular} & \begin{tabular}{|l|}
2510 \\
245.0009644 \\
\end{tabular} & $\begin{array}{l}2511 \\
245.0009644 \\
\end{array}$ & $\begin{array}{l}2512 \\
245.0009644 \\
\end{array}$ & \begin{tabular}{|c|}
2513 \\
240.0009644 \\
\end{tabular} & \begin{tabular}{l|l|}
2514 \\
235.0009644 \\
\end{tabular} \\
\hline & & & & & & & & & & & & & & & \\
\hline $\begin{array}{l}\text { Hydrogen } \\
\text { CO }\end{array}$ & 霉 & $\begin{array}{l}5604.817326 \\
360427763\end{array}$ & & 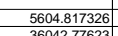 & 7027.5182010 & & $\frac{7027.51820}{10}$ & $\begin{array}{l}7027.518201 \\
16753242\end{array}$ & 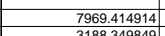 & & 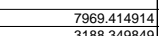 & 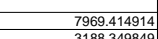 & & 7969.4414914 & 7969.414914 \\
\hline Nitrogen & $\begin{array}{l}3044.17025 \\
493.7147423\end{array}$ & $\begin{array}{l}36042.77623 \\
493.714742\end{array}$ & & $\begin{array}{l}30442.17025 \\
493.7147423\end{array}$ & $\frac{1625.3 .34424}{493.7147423}$ & & $\frac{16255.34424}{493.7147423}$ & $\frac{16255.34424}{493.7147423}$ & $\begin{array}{l}3188.3498949 \\
493.7147423\end{array}$ & & $\begin{array}{l}31883.3498499 \\
493.7147423\end{array}$ & $\frac{31983.349849}{493.7147423}$ & & $\begin{array}{l}3188.3498949 \\
493.7147423\end{array}$ & $\begin{array}{l}\frac{3188.3498849}{493.7147423} \\
\end{array}$ \\
\hline $\begin{array}{l}\text { oxygen } \\
\text { oxcon }\end{array}$ & $\begin{array}{r}6.9353 \mathrm{E}=06 \\
1.09887-07\end{array}$ & \begin{tabular}{|c|}
$6.9353 \mathrm{E}-06$ \\
$1.09987-07$
\end{tabular} & & \begin{tabular}{|c|}
$6.9353 \mathrm{E}-06$ \\
$1.0908 \mathrm{E}-07$
\end{tabular} & $\begin{array}{l}6.93535-06 \\
1.90987 F-07 \\
\end{array}$ & & $\begin{array}{l}6.93935-06 \\
1.909877-07\end{array}$ & $\begin{array}{c}6.9353 \mathrm{E}-06 \\
1.09807-07\end{array}$ & \begin{tabular}{|c|}
$6.93537-6-6$ \\
$1.09087-07$
\end{tabular} & & $\begin{array}{c}6.9353 E-06 \\
109087-0.07\end{array}$ & $\begin{array}{c}6.9353 \mathrm{E}-06 \\
10087-06\end{array}$ & & \begin{tabular}{|c|c|}
$6.9353 E-06$ \\
$1009857-06$
\end{tabular} & 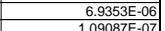 \\
\hline$\frac{\mathrm{CO} 2}{0.2}$ & 38735.75647 & 38735.75647 & 4591490 & 38735.75647 & 69993.62443 & & 0.9795 .624435 & 69793.62443 & 90355.435150 & & 90355.43105 & 903555.43105 & & 90355.43105 & 90355.435105 \\
\hline $\mathrm{H} 2 \mathrm{~S}$ & 1.73115767 & & 45914.91934 & & 33648.195997 & & & & & & & & & & 25231.346833 \\
\hline nonia & 0.11746690 & 0.117466907 & & 0.11746690 & 00 & & 0.117466907 & 0.117466907 & 0.11746690 & & 0.11746690 & 0 & & $\begin{array}{r}0.117466907 \\
\end{array}$ & 174 \\
\hline $\begin{array}{l}\text { No2 } \\
\text { Methane }\end{array}$ & $\begin{array}{r}1253.528153 \\
\end{array}$ & $\begin{array}{r}0 \\
1253.528153\end{array}$ & & $\begin{array}{r}0 \\
1253.528153\end{array}$ & $\begin{array}{r}0 \\
1253.528153\end{array}$ & & 0 & $\begin{array}{r}0 \\
1253.528153\end{array}$ & \begin{tabular}{r|}
1253.528153 \\
\end{tabular} & & $\begin{array}{r}0 \\
1253.528153\end{array}$ & $\begin{array}{r}0 \\
1253.528153\end{array}$ & & \begin{tabular}{r|}
1253.528153 \\
\end{tabular} & \\
\hline 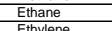 & 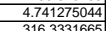 & $\begin{array}{l}4.741275044 \\
312325\end{array}$ & & $\begin{array}{l}4.741275044 \\
312323656\end{array}$ & $\begin{array}{l}4.741275044 \\
3.2331\end{array}$ & & $\begin{array}{l}4.74127504 \\
3\end{array}$ & $\begin{array}{l}4.741275044 \\
31623206\end{array}$ & $\begin{array}{l}4.741275044 \\
3123232656\end{array}$ & & & 4.741275044 & & $\begin{array}{l}4.741275044 \\
.7722304\end{array}$ & $\begin{array}{l}4.741275044 \\
.442745\end{array}$ \\
\hline $\begin{array}{l}\text { EEyylene } \\
\text { Acetylyene }\end{array}$ & $\begin{array}{l}336.33361655 \\
18.957861\end{array}$ & $\begin{array}{r}36.333655 \\
18577861\end{array}$ & & $\begin{array}{r}316.6333665 \\
18.9577861\end{array}$ & $\begin{array}{r}3.6 .33361655 \\
18.9577861\end{array}$ & & $\begin{array}{l}316.33331665 \\
18.9577861\end{array}$ & $\begin{array}{r}316.6333656 \\
18.9577861 \\
\end{array}$ & $\begin{array}{r}31.63333655 \\
18.9577861\end{array}$ & & $\begin{array}{r}316.3333656 \\
18.9577861 \\
\end{array}$ & $\begin{array}{r}336.33361655 \\
18.957861 \\
\end{array}$ & & $\begin{array}{r}316.63333656 \\
18.9577861\end{array}$ & $\begin{array}{l}\frac{316.33316}{18.95778} \\
\end{array}$ \\
\hline $\begin{array}{l}\text { n-Butane } \\
\text { i-Pentane }\end{array}$ & & & & & & & & & & & & & & & \\
\hline n-Pentane & & & & & & & & & & & & & & & \\
\hline $\begin{array}{l}\text { Benzene } \\
\end{array}$ & 6.272815702 & 6.272815702 & & 6.272815702 & 6.272815702 & & 6.272815702 & 6.272815702 & 6.272815702 & & 6.272815702 & 6.272815702 & & 6.272815702 & 6.272815 \\
\hline 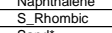 & & & & & & & & & & & & & & $6 \frac{62}{0}$ & \\
\hline $\begin{array}{l}\text { Salver } \\
\text { Sitover }\end{array}$ & & & & & 8 & & & & & & & & & $\frac{0}{0}$ & \\
\hline 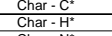 & & & & & $\frac{0}{0}$ & & & tra & d & & & & & & \\
\hline $\begin{array}{l}\text { Char }-N^{*} \\
\text { Char } \mathrm{S}^{*}\end{array}$ & & & & & & & & & 0 & & & & & & \\
\hline 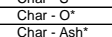 & & & & & & & & & & & & & & & \\
\hline 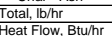 & $\begin{array}{l}82927.24863 \\
-190535670.9\end{array}$ & \begin{tabular}{|c|}
82925.5 .51747 \\
-1.9053554 .9
\end{tabular} & $\begin{array}{l}45914.91934 \\
-{ }_{25252154242.6}\end{array}$ & $\begin{array}{r}128840.4368 \\
-444355007.5\end{array}$ & $\frac{128840.2301}{-4-435150103.3}$ & & $\frac{128840.2301}{-4-46621258.1}$ & $\begin{aligned} 228840.2301 \\
-4356357\end{aligned}$ & $\begin{array}{r}128840.0899 \\
-47536557.7\end{array}$ & & 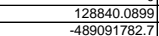 & $\begin{array}{l}128840.08999 \\
-484909172.7\end{array}$ & & 128840.09999 & $\begin{array}{r}128840.08999 \\
-52526887.1\end{array}$ \\
\hline
\end{tabular}

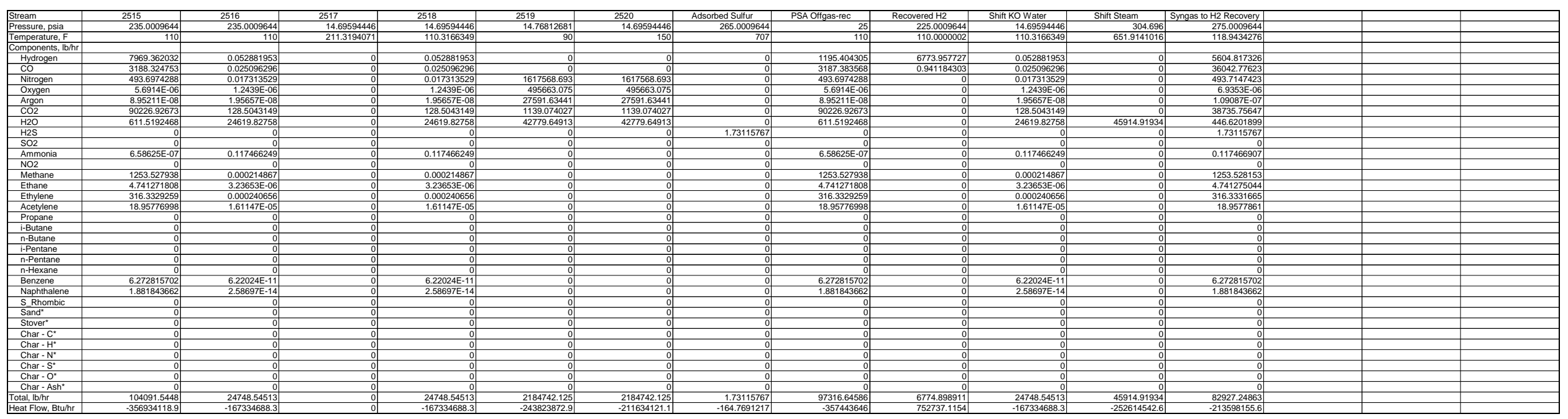



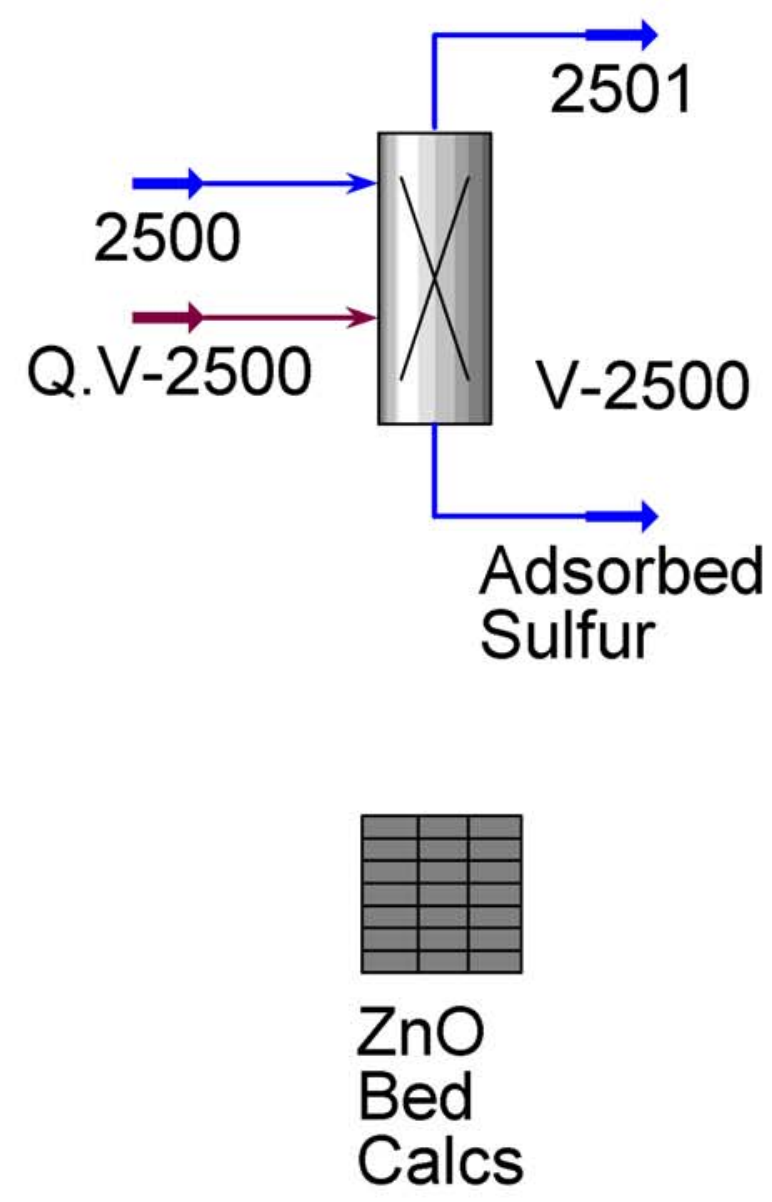
DE-FG36-03G013010

ZeaChem, Inc.

Flowsheet: ZnO Beds (ZNO)

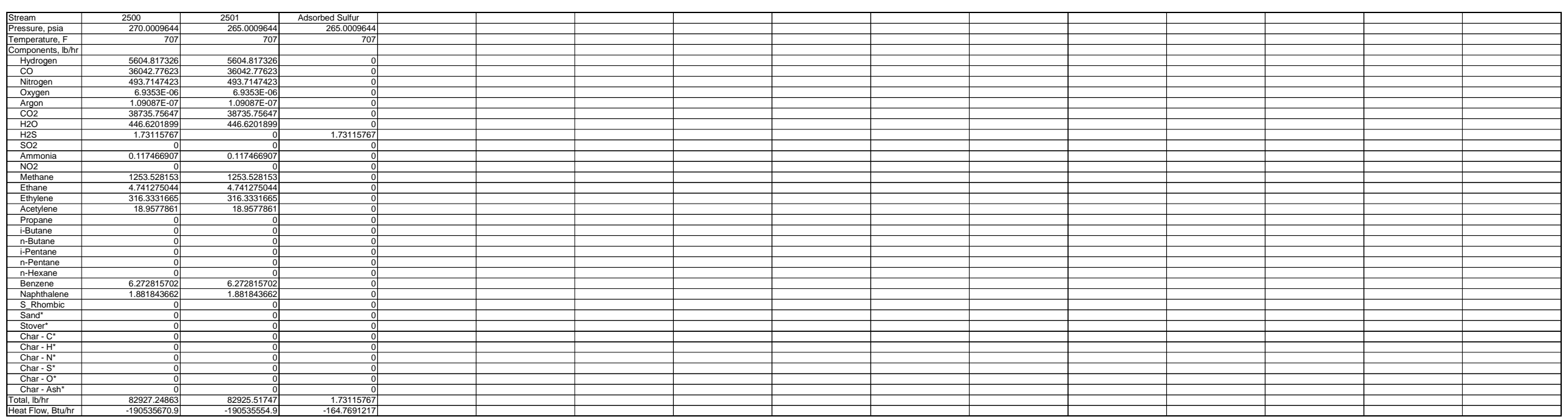




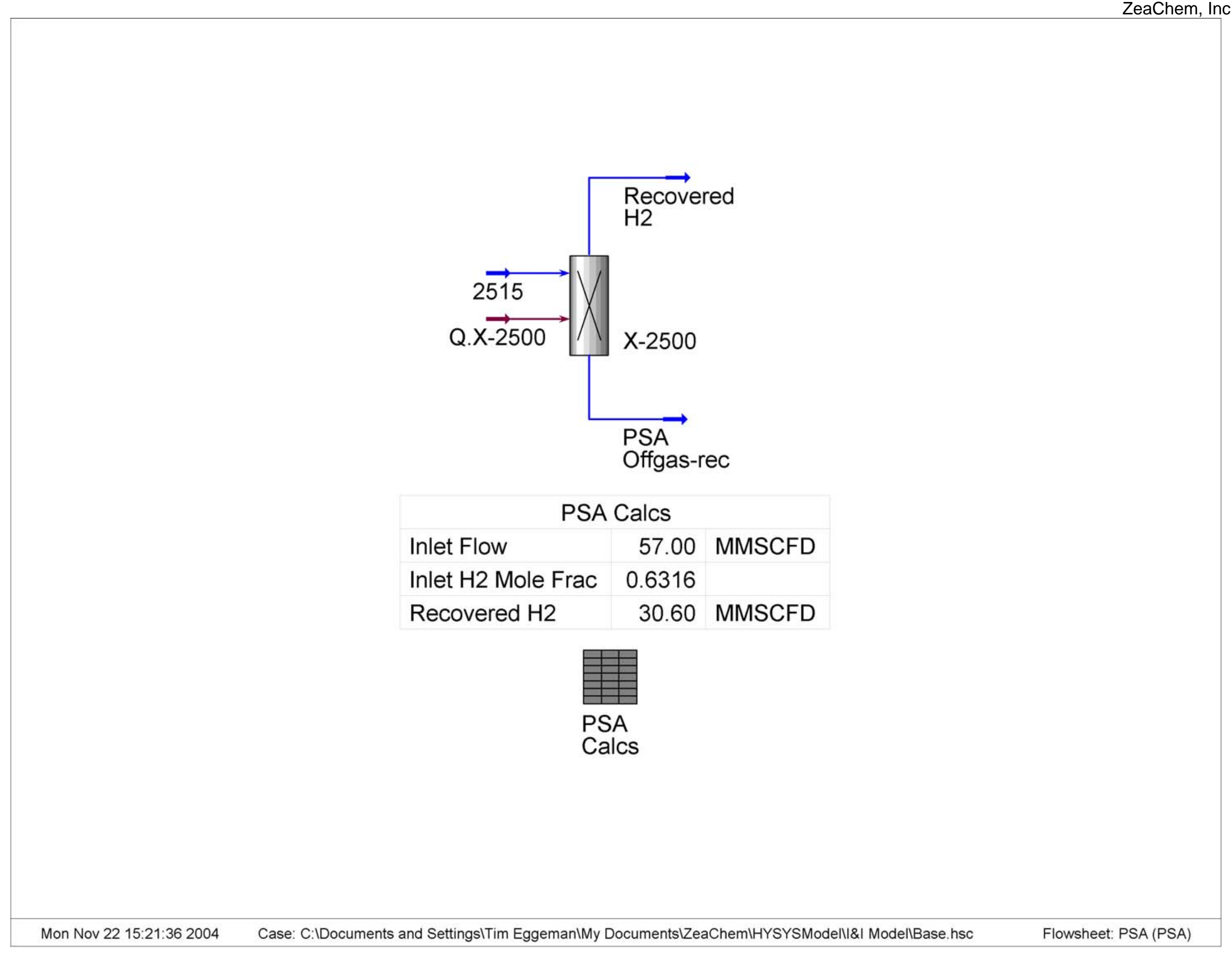


DE-FG36-03G013010

ZeaChem, Inc.

Flowsheet: PSA (PSA)

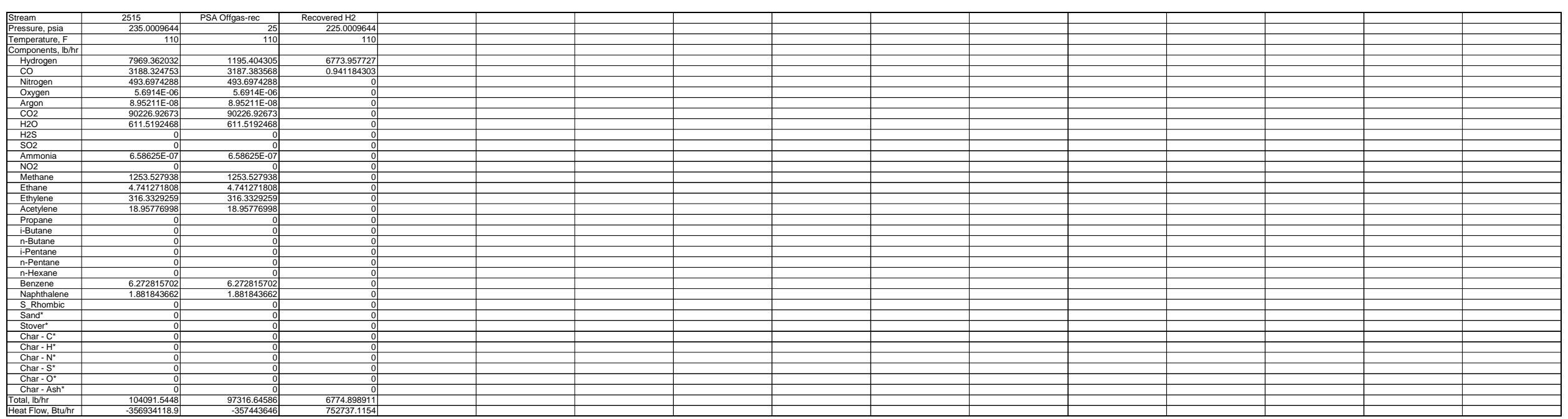



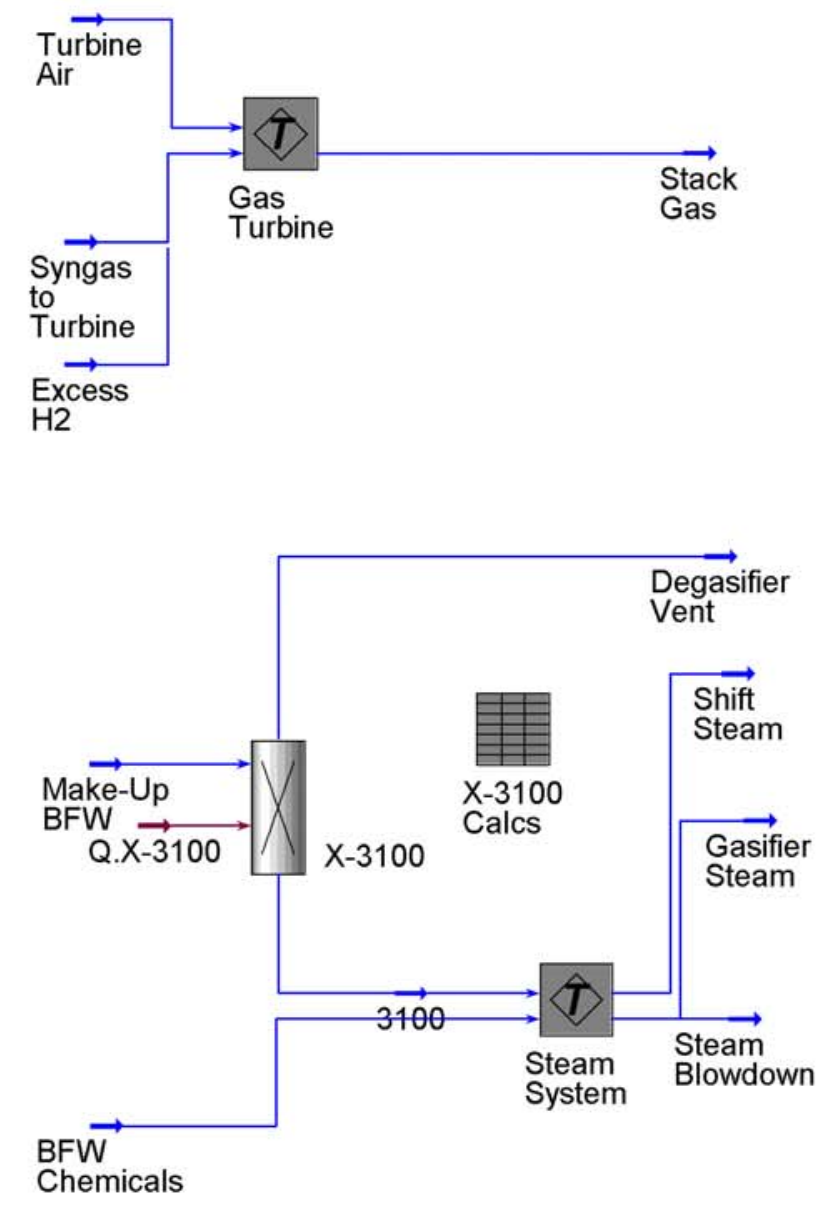
DE-FG36-03G013010

ZeaChem, Inc.

Flowsheet: Cogeneration (COGN)

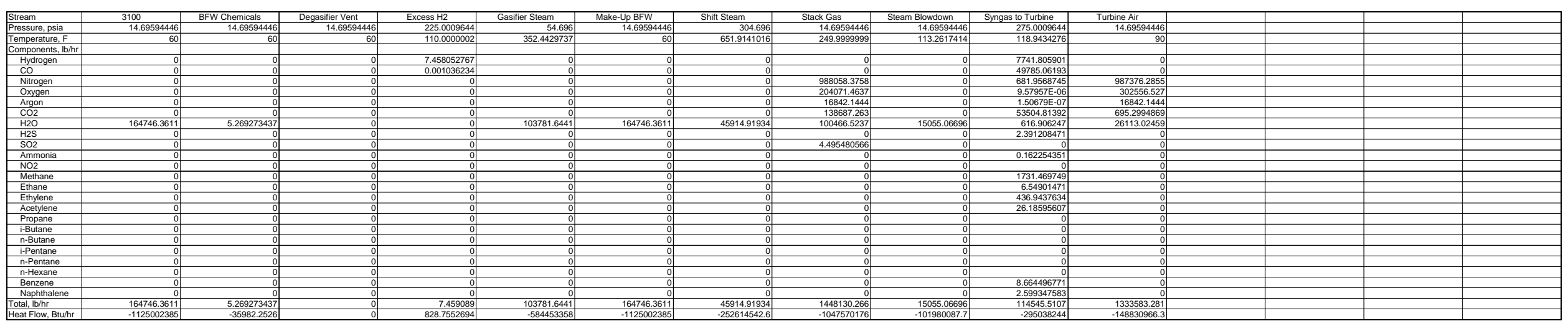


DE-FG36-03G013010

ZeaChem, Inc.

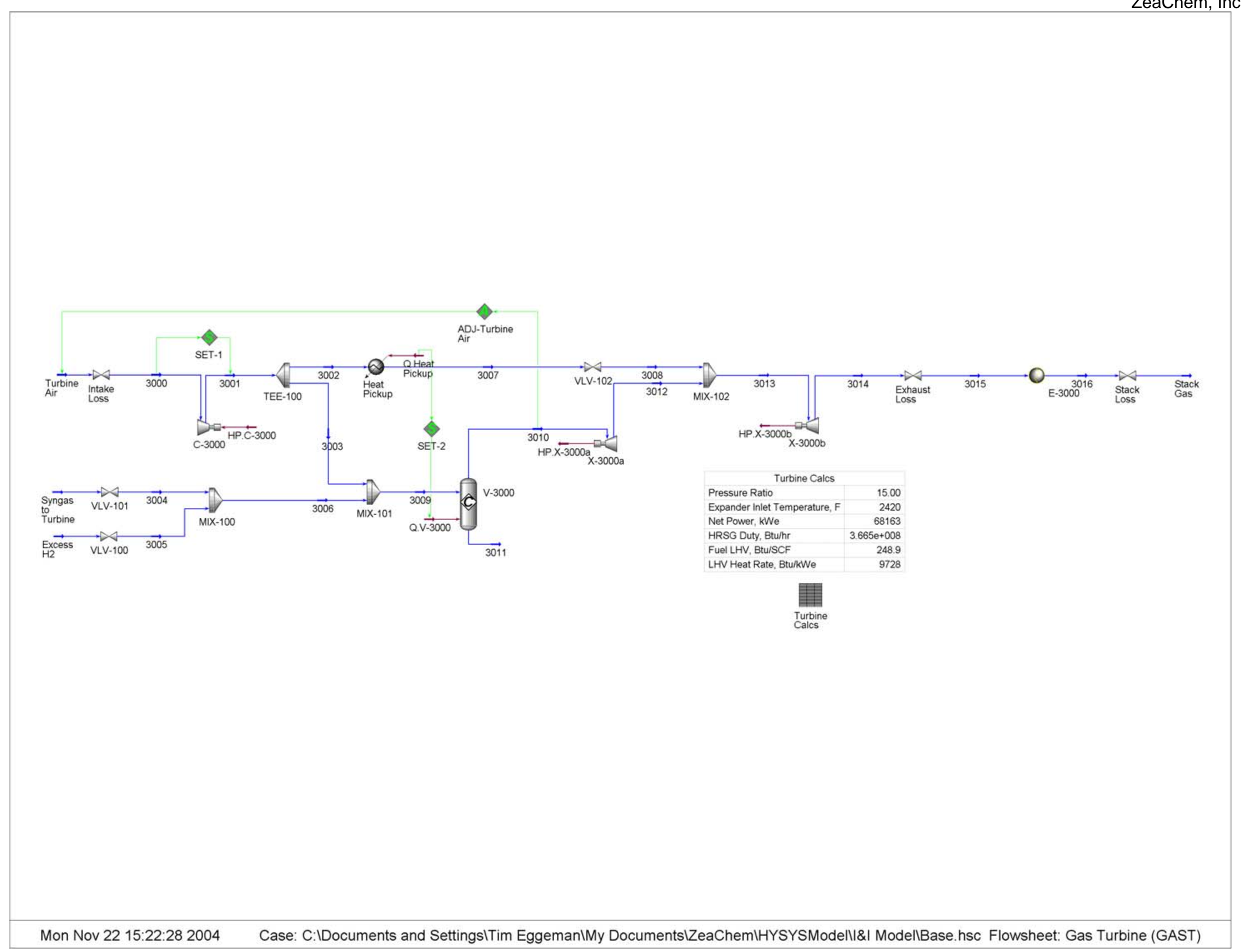


DE-FG36-03G013010

ZeaChem, Inc.

Flowsheet: Gas Turbine (GAST)
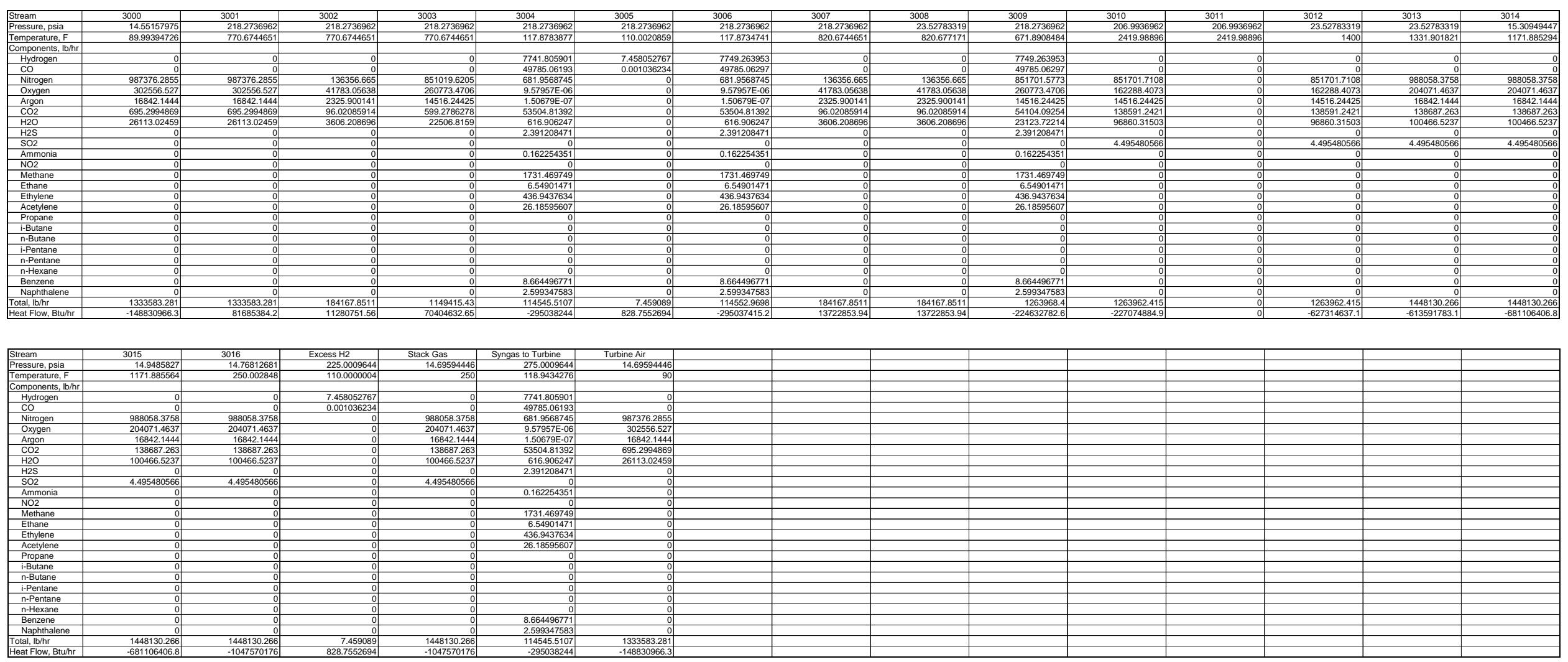
DE-FG36-03G013010

ZeaChem, Inc.

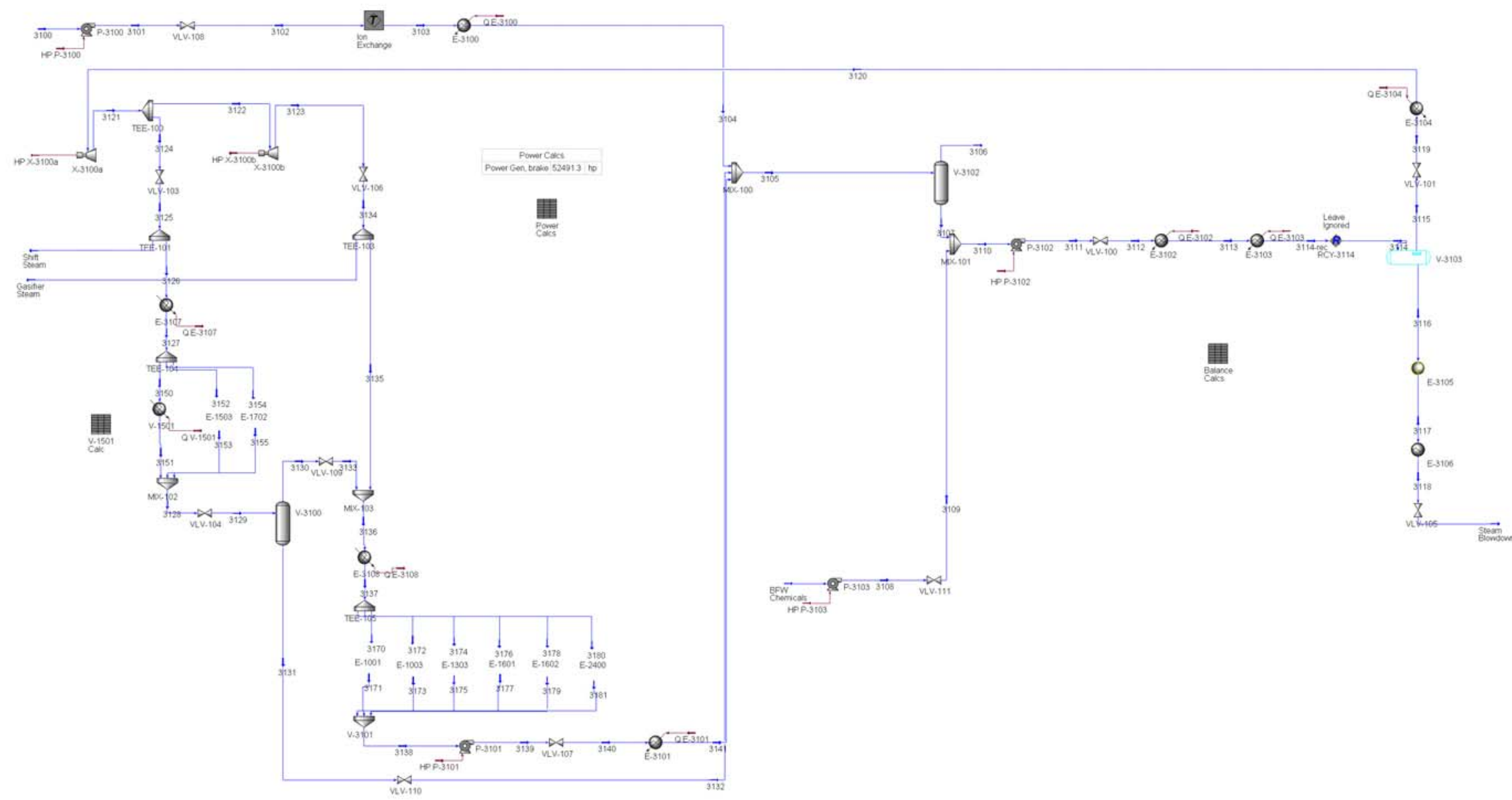


DE-FG36-03G013010

Flowsheet: Steam System (STEM)

ZeaChem, Inc.

\begin{tabular}{|c|c|c|c|c|c|c|c|c|c|c|c|c|c|c|c|}
\hline $\begin{array}{l}\text { tream } \\
\text { ressure, } \\
\text { emperat }\end{array}$ & \begin{tabular}{|l|l|}
3100 \\
14.69594446 \\
6
\end{tabular} & \begin{tabular}{|c|}
$3101 \quad 84.696$ \\
60.07868882 \\
\end{tabular} & $\begin{array}{|cc|}3102 & 74.666 \\
60.10698981 \\
\end{array}$ & \begin{tabular}{|c|}
3103 \\
60.121 .6966 \\
604775
\end{tabular} & \begin{tabular}{r|}
$3104 \quad 64.696$ \\
297.6656079 \\
\end{tabular} & \begin{tabular}{|c|}
3105 \\
297.664 .6966 \\
\end{tabular} & \begin{tabular}{|r|}
3106 \\
297.696 \\
297.6674276
\end{tabular} & 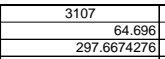 & \begin{tabular}{|c|}
3108 \\
60.0674 .6936 \\
60638
\end{tabular} & \begin{tabular}{|c|}
$3109 \quad 64.696$ \\
60.09574455
\end{tabular} & \begin{tabular}{|c|}
3110 \\
294.696 \\
29.6558002 \\
\end{tabular} & \begin{tabular}{|c|}
3111 \\
3034.68560129 \\
300.6809
\end{tabular} & $\begin{array}{r}\frac{3112}{11284.696} \\
300.776451 \\
\end{array}$ & \begin{tabular}{r|}
3113 \\
57279.696 \\
575.392046 \\
\end{tabular} & \begin{tabular}{|l|}
3114 \\
1279.696 \\
575.3938389 \\
\end{tabular} \\
\hline omponerer & & $\begin{array}{l}164746.3611 \\
104677636311\end{array}$ & $\begin{array}{l}196474663311 \\
64746.3611\end{array}$ & 164746.3611 & $\begin{array}{l}164746.3611 \\
164746.3611 \\
\end{array}$ & $\begin{array}{l}75274 \\
755274\end{array}$ & & 7527 & 5.2692739377 & $\frac{5.2692739377}{5.2696734377}$ & & & & & \\
\hline
\end{tabular}

\begin{tabular}{|c|c|c|c|c|c|c|c|c|c|c|c|c|c|c|c|}
\hline sscure, & $\begin{array}{l}3114 \text {-rec } \\
1279.6966 \\
\end{array}$ & $\begin{array}{r}3115 \\
1279.696 \\
5\end{array}$ & \begin{tabular}{|l|l|}
3116 \\
1279.696 \\
5
\end{tabular} & \begin{tabular}{|l|l|}
1274.696 \\
\end{tabular} & $\begin{array}{l}3118 \\
1269.696 \\
\end{array}$ & \begin{tabular}{r|}
3119 \\
1269.696 \\
512
\end{tabular} & \begin{tabular}{r|}
3120 \\
1264.696 \\
\end{tabular} & \begin{tabular}{r|}
3121 \\
314.696 \\
506
\end{tabular} & \begin{tabular}{r|}
3122 \\
314.696
\end{tabular} & \begin{tabular}{|l|l|}
3123 & 64.696 \\
\end{tabular} & \begin{tabular}{|l|l|}
3124 & 314.696 \\
05566
\end{tabular} & \begin{tabular}{|l|}
3125 \\
304.696 \\
\end{tabular} & $\begin{array}{l}3126 \quad 304.696 \\
6566\end{array}$ & ${ }_{3127}^{304.696}$ & $\frac{228}{41725}$ \\
\hline 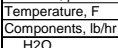 & $\begin{aligned} 575.393 \\
752753 \\
\end{aligned}$ & 575.39 & 575.39 & & & 574.388. & $\begin{array}{r}1000 \\
7376982811 \\
\end{array}$ & 653.0887284 & & & & & & & \\
\hline 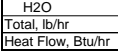 & $\begin{array}{l}\frac{75253.34381}{7527531} \\
-4273622098 \\
\end{array}$ & 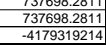 & 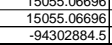 & 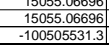 & $\begin{array}{l}15055.066966 \\
1505.0696 \\
-1018560800 \\
\end{array}$ & 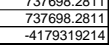 & 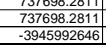 & 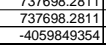 & 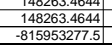 & 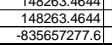 & $\begin{array}{l}5894438.8167 \\
-324389676\end{array}$ & $\begin{array}{r}584348.8167 \\
-3243896076\end{array}$ & $\begin{array}{l}534519.8 \\
50927\end{array}$ & 543511 & \\
\hline
\end{tabular}

\begin{tabular}{|c|c|c|c|c|c|c|c|c|c|c|c|c|c|c|c|}
\hline \begin{tabular}{|l|} 
Stream \\
Pressure, psia \\
Presta
\end{tabular} & $\begin{array}{ll}3129 & 64.696 \\
\end{array}$ & $\begin{array}{l}3130 \quad 64.696 \\
6.966\end{array}$ & \begin{tabular}{r|}
3131 \\
3134.696 \\
\end{tabular} & $\begin{array}{l}3132 \\
64.696 \\
\end{array}$ & $\begin{array}{l}3133 \\
34.696 \\
\end{array}$ & $\begin{array}{l}3134 \quad 54.696 \\
50275\end{array}$ & $\begin{array}{ll}3135 & \\
4.696 & \end{array}$ & $\begin{array}{|ll|}3136 & \\
4.696\end{array}$ & $\begin{array}{rr}3137 & \\
& 54.0966 \\
\end{array}$ & $\begin{array}{rr}3138 & 49.696 \\
& 49.696 \\
\end{array}$ & $\begin{array}{r}3139 \\
139.696 \\
\end{array}$ & $\begin{array}{ll}3140 \quad 69.696 \\
\end{array}$ & $\begin{array}{r}3141 \\
64.696 \\
\end{array}$ & $\begin{array}{l}3150 \\
304.696 \\
\end{array}$ & \begin{tabular}{r|}
3151 \\
417.291 .7966
\end{tabular} \\
\hline $\begin{array}{c}\text { Tomperature, } \mathrm{F} \\
\text { of }\end{array}$ & & & & 297.66466205 & 292.743949 & $\begin{array}{r}352.4429737 \\
148263.4644 \\
\end{array}$ & 352.4429737 & 314.5699238 & 286.7221265 & 280.6313062 & 280.6994453 & 280.7184115 & 297.6656079 & 4.18.77449966 & 417.2517896 \\
\hline $\begin{array}{l}\text { Hal, Ib/hr } \\
\text { Theat Flow, Btuhr } \\
\text { Heat }\end{array}$ & 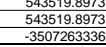 & 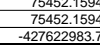 & $\begin{array}{r}46806067.783 \\
-30796940353 \\
\end{array}$ & 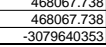 & $\begin{array}{r}75452.1594 \\
-42762.1594 \\
-4272933.7 \\
\end{array}$ & 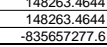 & 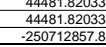 & 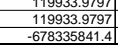 & 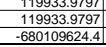 & $\begin{array}{l}119933.999797 \\
.799201378 .2 \\
\end{array}$ & 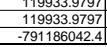 & 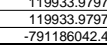 & $\begin{array}{l}11939333999797 \\
.789103077 .6 \\
\end{array}$ & $\begin{array}{r}-83800.9257 \\
-87297070760.8 \\
4\end{array}$ & 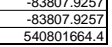 \\
\hline
\end{tabular}

\begin{tabular}{|c|c|c|c|c|c|c|c|c|c|c|c|c|c|c|c|}
\hline & 3152 & 3153 & $3154 \quad 304.696$ & \begin{tabular}{|l|l|}
3155 \\
299.696
\end{tabular} & $\begin{array}{ll}3170 \quad 54.696 \\
3\end{array}$ & \begin{tabular}{|l|}
3171 \\
49.696
\end{tabular} & $\begin{array}{ll}3172 \quad 54,696 \\
\end{array}$ & \begin{tabular}{|l|}
3173 \\
49.696
\end{tabular} & $\begin{array}{lll}3174 & \\
4.696 & \end{array}$ & \begin{tabular}{|l|l|}
3175 & 49.696 \\
\end{tabular} & \begin{tabular}{|l|l|}
3176 & 54.696 \\
\end{tabular} & 3177 & 3178 & 3179 & 3180 \\
\hline 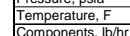 & 418.77449946 & $\begin{array}{l}417.25178966 \\
\end{array}$ & $\begin{array}{l}418.774494646 \\
\end{array}$ & $\begin{array}{l}417.2517896 \\
\end{array}$ & $\begin{array}{r}286.72212655 \\
\end{array}$ & $\begin{array}{r}280.63130602 \\
\end{array}$ & $\begin{array}{r}286.522121265 \\
\end{array}$ & $\begin{array}{r}48.6596 \\
280.6313062\end{array}$ & 286.72212665 & $\begin{array}{r}280.63130662 \\
\end{array}$ & 286.72212965 & & $\begin{array}{l}586.72192656 \\
\end{array}$ & & 286.722121265 \\
\hline 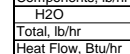 & 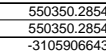 & 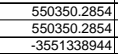 & $\begin{array}{l}76977.53762 \\
76977.5362 \\
-43443406\end{array}$ & 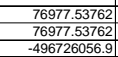 & 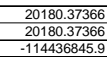 & $\begin{array}{l}20180.37366 \\
2018323736\end{array}$ & 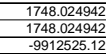 & 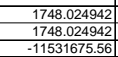 & 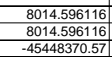 & 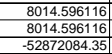 & -83675192. & & & $\begin{array}{l}74405.6 \\
-648873 \\
\end{array}$ & 57 \\
\hline
\end{tabular}

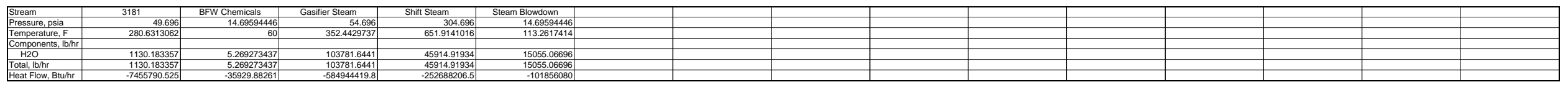


DE-FG36-03G013010

ZeaChem, Inc.

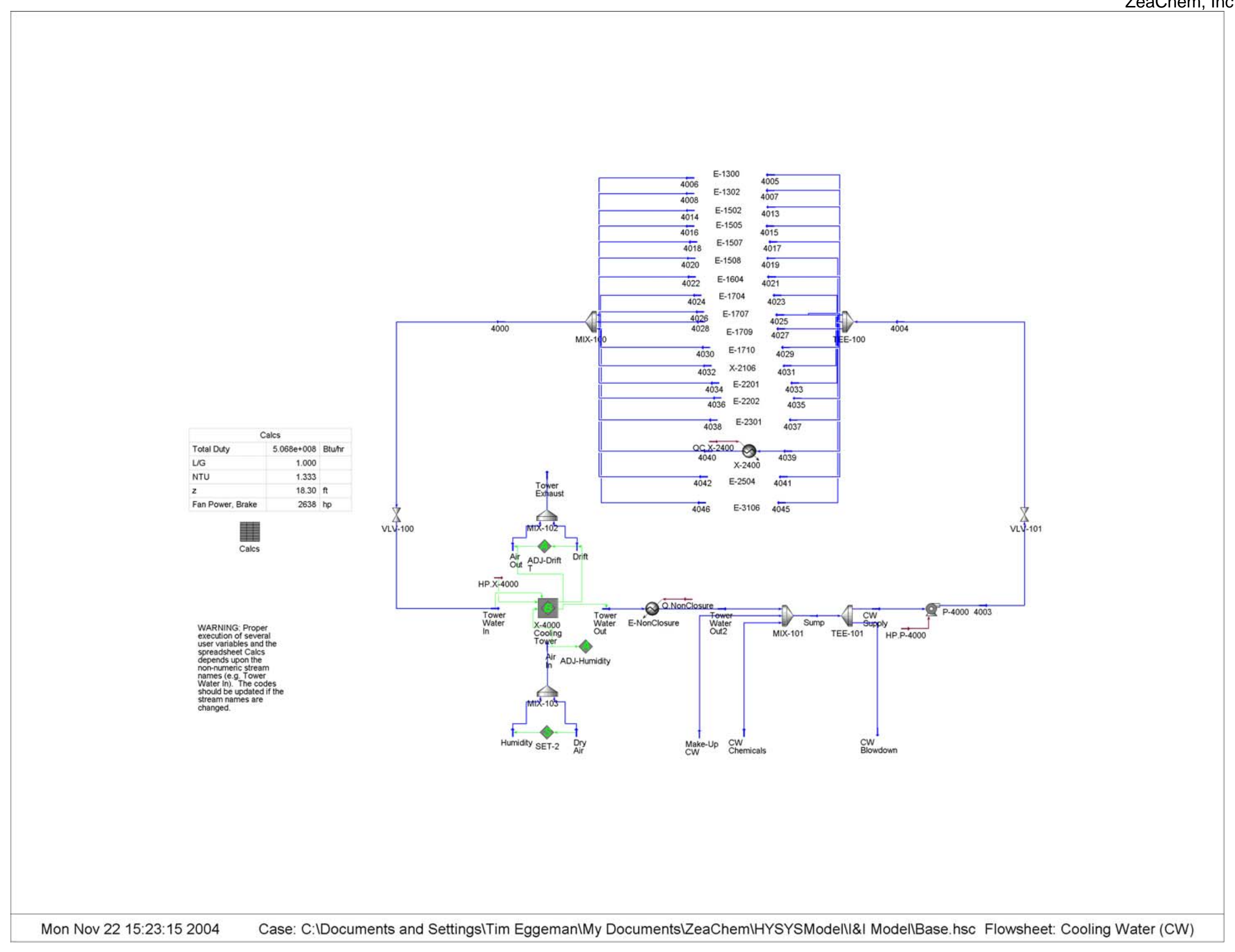


DE-FG36-03GO13010

Flowsheet: Cooling Water (CW)

ZeaChem, Inc.

\begin{tabular}{|c|c|c|c|c|c|c|c|c|c|c|c|c|c|c|c|}
\hline tream & $\begin{array}{l}4000 \\
59.69594446 \\
\end{array}$ & \begin{tabular}{l|l}
4003 \\
7.69594446
\end{tabular} & $\begin{array}{l}4004 \\
64.69594446\end{array}$ & $\begin{array}{l}4005 \\
64.6959444\end{array}$ & $\begin{array}{l}4006 \\
59.69594446 \\
\end{array}$ & $\begin{array}{l}4007 \\
64.69594446 \\
\end{array}$ & $\begin{array}{l}4008 \\
59.69594446 \\
\end{array}$ & $\begin{array}{l}4013 \\
64.69594446\end{array}$ & $\begin{array}{l}4014 \\
59.69594446 \\
\end{array}$ & $\begin{array}{l}4015 \\
64.69594446\end{array}$ & $\begin{array}{l}4016 \\
59.69594446\end{array}$ & $\begin{array}{l}4017 \\
64.69594446\end{array}$ & $\begin{array}{l}4018 \\
59.69594446 \\
4\end{array}$ & $\begin{array}{l}4019 \\
64.6959444\end{array}$ & \begin{tabular}{|l|l|}
4029.659446 \\
510 \\
\end{tabular} \\
\hline 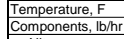 & & 89.97299816 & & & & & & & & & & & & & \\
\hline \begin{tabular}{|l|} 
Nitrogen \\
Oxxgen \\
\end{tabular} & & & & & & & & & & & & & & & \\
\hline $\begin{array}{l}\text { Argon } \\
\mathrm{COO} \\
\mathrm{H} 2 \mathrm{O}\end{array}$ & & & & & & & & & & & & & & & \\
\hline 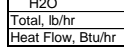 & 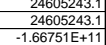 & 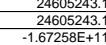 & 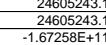 & $\begin{array}{l}3942545.0531 \\
394254.0531 \\
-265998625\end{array}$ & 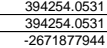 & 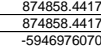 & 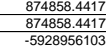 & 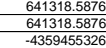 & 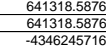 & 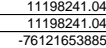 & 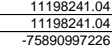 & 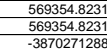 & 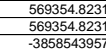 & 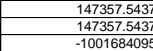 & 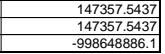 \\
\hline
\end{tabular}

\begin{tabular}{|c|c|c|c|c|c|c|c|c|c|c|c|c|c|c|c|}
\hline 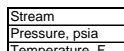 & $\begin{array}{l}4021 \\
64.69594446 \\
\end{array}$ & \begin{tabular}{|l}
4022 \\
59.695944446 \\
\end{tabular} & \begin{tabular}{|l|l|}
4023 \\
64.69594446 \\
\end{tabular} & $\begin{array}{l}4024 \\
59.69594446 \\
10\end{array}$ & $\begin{array}{l}4025 \\
64.69594446 \\
90\end{array}$ & $\begin{array}{l}4026 \\
59.69594446 \\
10\end{array}$ & \begin{tabular}{|l|l|}
4027 \\
64.69594446 \\
90
\end{tabular} & $\begin{array}{l}4028 \\
59.69594446 \\
10\end{array}$ & $\begin{array}{l}4029 \\
64.69594446 \\
90\end{array}$ & $\begin{array}{l}4030 \\
59.695944466 \\
10\end{array}$ & $\begin{array}{l}4031 \\
64.69594446 \\
\end{array}$ & $\begin{array}{l}4032 \\
59.69594446 \\
110\end{array}$ & $\begin{aligned} \frac{4033}{64.69594466} \\
9\end{aligned}$ & $\begin{array}{l}\frac{4034}{59.6959446} \\
110\end{array}$ & \begin{tabular}{|l|}
4035 \\
64.69594446 \\
90
\end{tabular} \\
\hline \begin{tabular}{|l} 
Temperature, $F$ \\
Components, $\mathrm{b} / \mathrm{hr}$ \\
\end{tabular} & & & & & & & & & & & & & & & \\
\hline \begin{tabular}{|l|} 
Nitrogen \\
Oxxgen \\
Argen
\end{tabular} & & 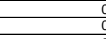 & & & & & & & & & & & & & \\
\hline cor & 72106.46176 & 7 & 3912110.431 & 3912110.431 & 3281689.642 & 3281689.642 & 333719.5351 & 333719.5351 & 97671.43674 & 97671.43674 & 388393.6053 & 388393.6053 & 2200645.352 & 22000645.352 & 57460.4888 \\
\hline 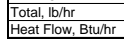 & $\begin{array}{l}721006.46176 \\
-490150433.3 \\
\end{array}$ & $\frac{7.72106 .46176}{-48866832.8}$ & 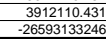 & $\frac{-39121110.4311}{-26552553241}$ & $\begin{array}{l}-3231689.642 \\
-.22307752777 \\
\end{array}$ & $\begin{array}{l}\frac{3281689.642}{-222420162424} \\
\end{array}$ & $\frac{33371955551}{-226560532}$ & $\begin{array}{l}\frac{333719.5351}{-2261632717} \\
-26327\end{array}$ & $\begin{array}{r}97671.43674 \\
-663935637.2 \\
-\end{array}$ & $\begin{array}{r}97671.43674 \\
-661923842 \\
\end{array}$ & $\begin{array}{l}388393.6053 \\
-2640161386 \\
\end{array}$ & $\begin{array}{l}\frac{3883933.6053}{-2632161418} \\
\end{array}$ & $\frac{2200645.352}{22032}$ & $\begin{aligned} \frac{2200645.352}{220064352} \\
-14913875285 \\
\end{aligned}$ & $\begin{array}{l}574060.4688 \\
50595935.9\end{array}$ \\
\hline
\end{tabular}

\begin{tabular}{|c|c|c|c|c|c|c|c|c|c|c|c|c|c|c|c|}
\hline-1 & 4036 & 4037 & 4038 & 4039 & 4040 & 4041 & 4042 & 4045 & 4046 & Air 10 & Air Out & CW Blowdown & CW Chemicals & CW Supp & $\begin{array}{l}\text { Drit } \\
14.65 \\
\end{array}$ \\
\hline $\begin{array}{l}\text { Pressure, , psia } \\
\text { Temperature, } \\
\end{array}$ & $\begin{array}{r}59.69594446 \\
110 \\
\end{array}$ & $\begin{array}{r}64.69599446 \\
90\end{array}$ & $\begin{array}{r}59.69594446 \\
110 \\
\end{array}$ & $\begin{aligned} 64.65994446 \\
96\end{aligned}$ & $\begin{array}{l}59.69594446 \\
110 \\
\end{array}$ & $\begin{array}{r}64.69594446 \\
90 \\
\end{array}$ & $\begin{array}{r}59.69594446 \\
110\end{array}$ & $\begin{array}{r}64.69594446 \\
90 \\
\end{array}$ & $\begin{array}{r}59.69594446 \\
110 \\
\end{array}$ & $\begin{array}{r}14.69594446 \\
90 \\
\end{array}$ & 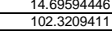 & $\begin{array}{r}14.69594446 \\
89.90452349 \\
\end{array}$ & $\begin{array}{r}14.69594446 \\
60 \\
\end{array}$ & $\begin{array}{r}14.69554446 \\
89.90452349 \\
\end{array}$ & $\begin{array}{l}14.699594446 \\
97.17346386 \\
\end{array}$ \\
\hline \begin{tabular}{|l} 
Components, , b/hr \\
Nitrogen, \\
\end{tabular} & & & & & & & & & & $\begin{array}{r}18551404.37 \\
5.502020 .144\end{array}$ & 18581404.37 & & & & \\
\hline \begin{tabular}{|l|} 
Oxygen \\
Argon \\
Co2
\end{tabular} & & & & & & & & & & 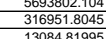 & $\begin{array}{r}56933002.104 \\
316951.8045 \\
13088.81995\end{array}$ & & & & \\
\hline tala, lb/hr & $\begin{array}{l}57466.4888 \\
57760.4888\end{array}$ & $\begin{array}{l}222790.1264 \\
222790.1264\end{array}$ & $\begin{array}{l}222790.1264 \\
2222790.01264\end{array}$ & $\begin{array}{l}2672.89452 \% \\
20672.295428\end{array}$ & $\begin{array}{l}2672.894528 \\
2677.894528\end{array}$ & $\begin{array}{l}145030.2786 \\
1145530.2776\end{array}$ & $\begin{array}{l}145030.2786 \\
145030.2786 \\
\end{array}$ & $\begin{array}{l}65568.35189 \\
65586.35189 \\
\end{array}$ & $\begin{array}{l}65568.35189 \\
65563.35189 \\
\end{array}$ & 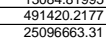 & 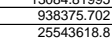 & $\frac{111738.87}{11171738.87}$ & $\begin{array}{l}\frac{4.921048619}{4.9212408619} \\
\end{array}$ & $\frac{246}{246}$ & $\frac{49210}{49210}$ \\
\hline 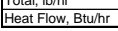 & 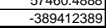 & 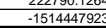 & & 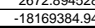 & $\begin{array}{l}-1812.89442928 \\
-1811429.78 \\
\end{array}$ & $\begin{array}{l}14030.2860 \\
-985864175.1 \\
\end{array}$ & $\begin{array}{l}145030.2766 \\
-98286902.4\end{array}$ & 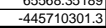 & $\begin{array}{r}-65563.35359 \\
-444359751.9 \\
\end{array}$ & $\begin{array}{l}-28000845354.31 \\
-2800 \\
\end{array}$ & 25291406543434 & 55877489.2 & $\begin{array}{l}\frac{4.921048619}{-33604.33209} \\
-\end{array}$ & 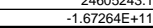 & $\begin{array}{l}-39411584 \\
-3344\end{array}$ \\
\hline
\end{tabular}

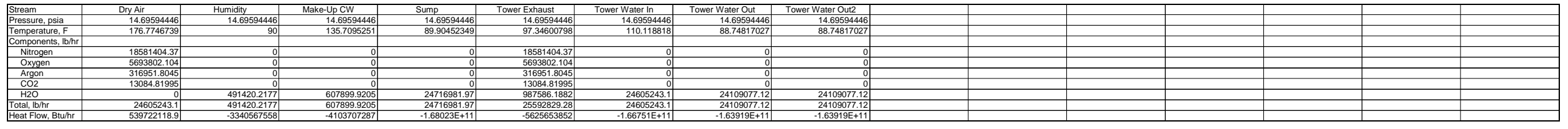




\section{Appendix $F$ Detailed Description of Base Case Economic Model}

This appendix provides a detailed discussion of the economic model developed for the base case. Table 1 summarizes the material balance, net power export and other important assumptions and results for the economic model. The base case material balance was developed for a plant capacity of $100 \mathrm{MMgal} / \mathrm{yr}$ ethanol (denatured), with starch hydrolyzate and corn steep water supplied by an across the fence wet milling, a corn stover gasification unit to supply hydrogen and a gas turbine+bottoming cycle to provide steam and power.

Capital costs, operating costs, and revenues from the process material and energy balances. These costs and revenues were combined into discounted cash flow calculations to evaluate project-level economics on a 100\% equity basis. Traditional single parameter sensitivity and Monte Carlo analysis were used to identify economic drivers. Each of these areas of the economic model will be discussed in detail in this appendix.

\section{Capital Costs}

Table 2 summaries the capital cost estimate. Capital costs are divided into three categories: Fixed Capital, Working Capital, and Start-up.

Fixed Capital - Fixed capital is estimated at \$297.3 MM, or roughly \$2.97 per annual gallon of capacity. The design basis uses both a conventional ethanol feedstock (e.g. starch hydrolyzate) and a less conventional lignocellulosic feed (e.g. corn stover). Projected fixed capital requirements for lignocellulosic based ethanol facilities are typically higher than for conventional corn dry mills.

A typical corn dry mill of equivalent capacity would require $\$ 1.00-1.50$ of fixed capital per annual gallon of capacity based on our survey of recent plant announcements in (1). In contrast, the goal case reported in (2) for a grassroots direct fermentation facility using corn stover as the feedstock estimates fixed capital at $\$ 2.85$ per gallon of annual capacity, with actual state of technology projections being much higher. The projected capital cost for the base case appears to be reasonable, after considering that infrastructure for processing lignocellulosic feeds is included in the model.

Standard factoring methods were used to construct the fixed capital estimate. The following basic methodology was used for process areas excluding the Feed Handling, Gasifier, and Conditioning sections of the Gasification and H2 Recovery area: 1) Size the individual pieces of process equipment using the process model material and energy balance as the basis, 2) Estimate the purchased equipment cost for each piece of equipment based on its size and a Chemical Engineering Index of 450 to adjust for any variances in the year of estimation, 3) Apply an installation factor, adjusted as needed based on the equipment type, to estimate the direct installed costs, 4) Apply additional factors to estimate indirect costs and project contingencies. 
Direct installed costs for the Feed Handling, Gasifier, and Conditioning sections of the Gasification and H2 Recovery area were based on (3), using the power law:

$$
\frac{\$_{1}}{\$_{2}}=\left(\frac{\text { Capacity }_{1}}{\text { Capacity }_{2}}\right)^{n}
$$

with $n=0.7$ to adjust for the difference in plant capacity. This area of the plant contains highly integrated and specialized process equipment, which for preliminary cost estimations, are more accurately estimated as a system rather than being built-up from individual pieces of equipment.

Table 3 presents the detailed fixed capital estimate. Each individual piece of equipment is identified with a tag number and name, a brief description of the equipment along with its size is given, the design temperature and pressure plus the materials of construction are stated, and the purchased equipment cost, installation factor and direct installed costs are presented. The purchased equipment costs were generated from a variety of sources. The software package Preliminary Design and Quotation Service (PDQS Inc., Gates Mills, OH) was used for estimating the purchase cost of many individual pieces of equipment, with supplemental sources such as vendor quotes from previous projects used for the rest.

Figure 1 divides the fixed capital estimate into directs, various indirect and contingency categories. Direct fixed capital is responsible for $71 \%$ of the total fixed capital. Figure 1 also shows the distribution of direct fixed capital by major process area. The direct fixed capital is nearly evenly divided across four categories: Fermentation and Recovery, Gasification and H2 Recovery, Utilities, and all other areas. One consequence of this nearly even distribution is that future process development efforts aimed at reducing capital costs for any one section of the plant will have a muted impact on process economics.

Working Capital - This category represents the amount of cash on-hand required to maintain an ongoing business. A crude estimate, based on 45 days of revenue, gives a working capital requirement of $\$ 19.7 \mathrm{MM}$.

Start-Up Costs - This category represents the cost, beyond contingency, required to bring the plant up to full production in the first few years of operation. Start-up costs were estimated at $5 \%$ of fixed capital, or $\$ 14.9 \mathrm{MM}$. In actual practice, start-up costs are allocated as both capital and operating expenses. In this estimate, they are identified in the capital summary as a part of the project's capital budget, but treated as an operating expense in the cash flow calculations.

\section{Operating Costs}

Table 4 summarizes the plant level operating cost estimate. Operating costs are divided into two categories: Variable costs, and Fixed Costs.

Variable Costs - Variable costs are proportional to the actual production rate. They can further divided into categories such as raw materials, catalysts, disposal, operating labor, etc. Table 4 shows that variable costs are dominated by the raw material costs for starch hydrolyzate, stover, and light steep water. None of these items are standard items of commerce, so some discussion is needed to justify the prices shown in Table 4. 
We assumed a starch hydrolyzate price of $\$ 0.05$ per lb (dry) in the base case economic model. The actual price of starch hydrolyzate would be set by a contractual agreement with the host corn wet mill. This agreement would most likely transfer commodity risk from the wet mill to the ethanol facility via a formula that takes into account fluctuations in corn and related wet mill co-product prices. The formula would also include a fixed margin to account for other processing costs and provide a financial return to the wet mill.

We have compiled cash costs for corn, unrefined corn oil, corn gluten meal, and corn gluten feed over the time period 1990-2004 (Chicago, IL basis) using data published in $(4,5)$. Figure 2 shows that net corn (nominal basis), defined as the cost of corn less the value of the non-starch co-products using the actual reported prices without adjustments for inflation, was fairly constant over this time period with the exception of the Midwest drought year of 1996 . Net corn ranged from $\$ 0.0179$ to $\$ 0.1011$ per lb of starch hydrolyzate (dry), with an average value of $\$ 0.0375$. Thus, the assumed transfer price of $\$ 0.05$ per lb (dry) used in our base case economic model would allow the mill a reasonable margin during an average year.

We assumed a price of $\$ 30$ per metric ton (dry) for corn stover. The projected price of corn stover has been studied extensively by the U.S. Department of Energy and its subcontractors. The $\$ 30$ per metric ton (dry) value used in our study is typical.

We assumed a light steep water price of \$130 per US ton (dry). Like starch hydrolyzate, the actual price would be set by a contractual agreement with the host corn wet mill. This value for light steep water was arrived at by valuing the protein content. Soybean meal, a good proxy for the value of protein, typically sells for about \$150 per US and contains 44 wt\% protein. The \$130 per US ton (dry) results after adjustment for the lower protein content of light steep water.

Fixed Costs - Fixed costs are defined as operating costs that are incurred independent of the actual production rate for the plant. Supervision, maintenance, plant overhead, depreciation, property taxes and insurance fall into this category. Standard factors, shown in Table 4, were used to estimate these fixed costs. Depreciation and maintenance are the two largest fixed operating costs categories, both of which are factored off of plant fixed capital.

\section{Revenues}

Table 5 shows that ethanol sales is the major revenue stream for the plant, followed by electricity sales then steep water return sales. We have compiled rack prices for denatured fuel grade ethanol, Midwest basis, over the time period 1990-2004 (6,7). The monthly data are plotted in Figure 3. Fuel ethanol prices have varied from $\$ 0.90-\$ 1.78$ per gallon (denatured), with an average price of $\$ 1.24$ per gallon (denatured) over this time period. We used the average price in the base case model.

Electricity markets have undergone significant deregulation in the past decade. The value of electricity depends upon many factors such as: time of day, geographic location, 
potential for green power credits, etc. The base case model assumes electricity sales are priced at an average of $\$ 0.05$ per $\mathrm{kWhr}$.

The value of steep water return was estimated from its protein content. The \$125 per US ton (dry) value used in the base case economic model was arrived at in the same manner as that used to value light steep water. In actual practice, the value of steep water return will be set by contract with the corn wet mill host.

The process model assumes the ammonia nitrogen in light steep water is converted into cell mass during fermentation, thus the plant is a net producer of protein. The net protein revenue (i.e. the revenue from steep water return less costs for light steep water) under the assumptions used in the model is $\$ 0.0624$ per gallon of ethanol (denatured).

\section{Discounted Cash Flows}

Discounted cash flow calculations use the time value of money concept to combine capital costs, operating costs, and revenues into one or more performance measures. The calculations can be done using either market pricing or rational pricing for the revenues, the choice of which depends upon the objectives of the analysis. Our base case model uses both market and rational price methods.

Market based pricing is commonly used in the private sector to evaluate the profitability of a potential project. In this method, a market analysis is used to establish the value of the products, the revenues are calculated using these market prices, and the cash flows for the project are then discounted at the corporate cost of capital. Our model uses a discount rate of $7 \%$ real with a $2 \%$ inflation rate, giving a $9 \%$ nominal discount rate which is within the range of values typically used in the private sector. The project is considered acceptable if the net present value (NPV) of the discounted cash flows is positive, or if the internal rate of return (IRR) is higher than the discount rate. In actual practice, the project is not accepted unless it is shown to be much more successful than the minimum requirement. Hurdle rates for the internal rate of return of $15-30 \%$ are often required to justify the increased risk of the project vs. other safer investments. These higher hurdle rates are also used by the corporation to limit, to a manageable number, the number of projects that are being pursued at any given time.

Rational pricing methods are commonly used in research environments. In this method, the assumed selling price for the product is not related to its market value. Rather, the assumed selling price is determined iteratively by requiring a zero net present value for the project when the cash flows are discounted at a given rate. The National Renewable Energy Laboratory, a leader in the field of bioethanol research, typically uses rational pricing with after tax cash flows discounted at $10 \%$ nominal in their analyses (2). This discount rate is low compared to typical corporate hurdle rates, but reflects the assumption that bioethanol will someday be a mature business. We have adopted the same discount rate (10\% nominal, after tax) in our rational pricing method.

Table 6 presents the cash flow calculations. Other pertinent assumptions used in the discounted cash flows: 1) Two years of construction, 2) First operating year at 64\% of nameplate 
capacity, second operating year at $85 \%$ of nameplate capacity, followed by twenty-three years of operation at $100 \%$ of nameplate capacity, 3) $100 \%$ equity investment, 4) Zero terminal value except for return of working capital, 5) Depreciation using 10 year MACRS, 6) Corporate overheads at $2 \%$ of revenues, and 7 ) Combined state and federal income tax rate of $37 \%$. A summary of results for the discounted case flow calculations for the base case is:

\section{Market Pricing}

Net Present Value, \$MM (After-tax, 9\% Nominal) $\quad-6.64$ Internal Rate of Return (After-tax) $\quad 8.7 \%$

Rational Ethanol Price, \$/gal (denatured) 1.29

The base case, as currently formulated, is not justifiable on an economic basis. Recommendations on means to improve the economic projections are discussed in Task 3 of the main body of this report.

Figure 4 presents the cost breakdown using Year 6 as the proof year. Net cash cost, defined as the price at which ethanol can be sold while maintaining the plant at cash flow breakeven, is $\$ 0.84$ per gallon ethanol (denatured). This is a significant measure since it defines the plant's competitive position within the existing industry. Ethanol prices have not dipped below $\$ 0.90$ per gallon (denatured) over the past 15 years, suggesting that this plant would most likely always be cash flow positive and would continue to operate during periods of depressed ethanol prices.

Net feed, defined as the difference between the cost of starch hydrolyzate+stover+light steep water less the revenues from electricity+steep water return, is $\$ 0.43$ per gallon of ethanol (denature) and is the largest single cost component. Strategies to lower this cost component (e.g. replace starch hydrolyzate with biomass hydrolyzate) would make the most impact on improving overall process economics.

\section{Sensitivity}

A series of sensitivity studies were conducted in which a single variable (e.g. fixed capital) was allowed to vary from its base value and the economic performance was re-evaluated with all parameters held constant. The purpose of these sensitivity studies is to point out areas that would have the most impact for improvements in the technology and its implementation.

Figure 5 shows the sensitivity of internal rate of return and rational ethanol price with respect to variations in fixed capital. Included in this sensitivity are secondary affects of variation in fixed capital on operating costs since several items (e.g. maintenance, property taxes) were assumed to be a factor of fixed capital. While variations in fixed capital do influence these performance measures, the effect is somewhat muted since feedstock and other non-capital related costs are significant economic drivers. For example, fixed capital would have to drop by about one-third to raise the after tax internal rate of return to $15.0 \%$ (nominal). 
Figure 6 shows the sensitivity of internal rate of return and rational ethanol price with respect to variations in starch hydrolyzate real price. The performance measures are sensitive to the cost of fermentable substrate. Attractive economic performance occurs for starch hydrolyzate prices below \$0.02 per lb (dry); negative performance measures occur for starch hydrolyzte prices above $\sim \$ 0.08$ per lb (dry). As stated earlier, starch hydrolyzate prices would most likely be set by a contract formula based on net corn plus a margin. The vertical lines on Figure 6 are the net corn values of starch hydrolyzate without margin at several selected values of corn prices. It is unlikely that contractual negotiations with the host corn wet mill would lead to starch hydrolyzate prices in the range of \$0.02 per lb (dry), suggesting that other low-cost fermentable sugar sources such as biomass hydrolyzates be pursued.

Figure 7 shows the sensitivity of internal rate of return and rational ethanol price with respect to variations in stover price. Attractive economic performance occurs for stover prices below $\$ 10$ per metric ton (dry); negative performance measures occur for stover prices above $\sim \$ 55$ per metric ton (dry). These results suggest that investigation of lower-cost gasifier feedstocks would be an area of profitable R\&D effort, especially when combined with other improvement efforts.

Figure 8 shows the sensitivity of internal rate of return and rational ethanol price with respect to variations in ethanol sales price. The internal rate of return is strongly affected by ethanol market price while, by definition, the rational ethanol price is not affected by ethanol market price. Historically, ethanol prices are correlated with gasoline prices, which in turn are correlated with crude oil prices. Recent prices for crude oil have exceeded \$50 per barrel; gasoline and fuel ethanol have been strong. At the time of this writing, rack prices for fuel ethanol are about $\$ 1.70$ per gallon. A plant could easily be justified under these price conditions. However, as shown earlier in Figure 3, fuel ethanol prices are quite volatile. It would have been quite difficult to justify an ethanol facility using the pricing environment of 1998-1999 and in early 2002.

Figure 9 shows the sensitivity of internal rate of return and rational ethanol price with respect to variations in electricity sales price. Attractive economic performance occurs for average electricity prices greater than $\sim \$ 0.10$ per kWhr. As mentioned earlier, electricity prices are functions of many variables. Locations with a high average electricity price and/or green power credit programs (e.g. California) would have an advantage during site selection.

Figure 10 shows the sensitivity of internal rate of return and rational ethanol price with respect to variations in steep water return price. The performance measures are somewhat insensitive to variations in steep water return price.

Figure 11 shows the sensitivity of rational ethanol price with respect to variations in discount rate. If the discount rate were raised to a typical hurdle rate of $15 \%$ (nominal, after tax), the rational ethanol price would rise from \$1.29 to \$1.54 per gallon of ethanol (denatured) to reflect the higher value placed on capital. 


\section{Monte Carlo}

Single parameter sensitivity analysis is useful for directing areas of future research, however, it often fails to convey the financial risks of the project. In the Monte Carlo method, a probability distribution is assigned to each key input variable, a random number sequence is then used to define values for these key input variables, and the output variables from the model are tabulated. The resulting distributions display the range of likely results when more than one input variable is changed at a time.

Figure 12 summarizes the assumed probability distributions for the key input variables, and displays the resulting distributions for after tax internal rate of return and net present value. According to the shaded areas of the NPV chart, there is a $56.62 \%$ chance that the project will have a negative net present value under the assumptions used in the Monte Carlo analysis. The IRR of the project is slightly below the discount rate ( $8.7 \%$ vs. $9.0 \%)$, so the prediction that there is a significant chance of a negative net present value for this project is not surprising. Monte Carlo analyses, such as this one, are often used to justify the risk premium required when setting corporate policies on acceptable hurdle rates.

\section{References}

1) Ethanol Producer Magazine, BBI International, www.ethanolproducer.com

2) Aden, A., Ruth, M., Ibsen, K., Jechura, J., Neeves, K., Sheehan, J., Wallace, B., Montague, L., Slayton, A., Lukas, J., "Lignocellulosic Biomass to Ethanol Process Design and Economics Utilizing Co-Current Dilute Acid Prehydrolysis and Enzymatic Hydrolysis for Corn Stover", National Renewable Energy Laboratory, NREL/TP-510-32438, June, 2002.

3) Spath, P, Eggeman, T., Aden, A., Ringer, M, NREL Report, December, 2004 (in press).

4) Feedstuffs, www.feedstuffs.com/ME2/default.asp.

5) The Wall Street Journal.

6) Coltrain, D., "Economic Issues with Ethanol”, Risk and Profit Conference, Kansas State University, August 2001.

www.agecon.ksu.edu/home/Research\&Extension/risk\%20and\%20profit/archived\%papers/risk01 coltrain.pdf.

7) Hart’s Oxy-Fuel News. Later incorporated into: Hart’s Renewable Fuel News. www.worldfuels.com. 


\section{Table 1 - Design Summary}

\section{Material Balance}

BFW Chemicals

$\mathrm{CO} 2$

Combustor Air

CW Chemicals

Desulfurization Air

Dry Air

Fresh $\mathrm{CaCO} 3$

Fresh Solvent

Fresh TBA

Fresh Water

Humidity

Inert Gas

Inhibitors

Light Steep Water

Lime

Make-Up Sand

$\mathrm{MgO}$

Minerals

Natural Gasoline

Reductant

Regen Air

Starch Hydrolyzate

Stover

Turbine Air \begin{aligned} $\mathrm{lb} / \mathrm{hr} \\$\hline 5\end{aligned}

634
-631

5,631

529

$24,605,243$

$-129$

62

$1,128,875$

491,420

24

349,708

2,130

2,130
2,995

197

1,032

3,209

187
205,477

68,335

306,774

333,583

Total $29,349,065$
Out

Adsorbed Sulfur

Ash

Bulk Sulfur

Combustor Offgas

Denatured EtOH

631,339
79,280

Desulfurization Offgas 434

$\begin{array}{lr}\text { Regen Offgas } & 331,755 \\ \text { Solids } & 628\end{array}$

Stack Gas 1,448,130

Steep Water Return

Tower Exhaust 25,592,829

Vents

Water Out

Total $29,349,045$

\section{Utilities}

Net Power Export, kWe

62,524

\section{Other}

Operating Hours per Year

8330

Denatured EtOH, MMgal/yr

Stover, Metric Ton/d (dry)

Starch Hydrolyzate, wt\% DS

Stover, wt\% Water

$30.0 \%$

Light Steep Water, wt\% DS

$15.0 \%$

Steep Water Return, wt\% DS

Nat. Gasoline Density, Ib/ft3 


\section{Table 2 - Capital Summary}

(Factored Estimate)

Fixed Capital

$\begin{array}{ll}\text { Directs } & \text { Feed Prep } \\ & \text { Fermentation } \\ & \text { Pre-Concentration } \\ & \text { Acidification } \\ & \text { Extraction } \\ & \text { Esterification+Fractionation } \\ & \text { Water Management } \\ & \text { Hydrogenolysis } \\ & \text { Denaturing } \\ & \text { Feed Handling } \\ & \text { Gasification } \\ & \text { Conditioning } \\ & \text { Compression } \\ & \text { Bulk Desulfurization } \\ & \text { H2 Recovery } \\ & \text { Gas Turbine } \\ & \text { Steam System } \\ & \text { Cooling Water } \\ & \text { Other Utilities } \\ & \text { Other OSBL } \\ & \\ \text { Indirects } & \text { Home Office } \\ & \text { Outside Engineering } \\ \text { Construction Expense } \\ \text { Contractor's Fee } \\ \\ \end{array}$

Total Capital

Fixed Capital

Start-up

\begin{tabular}{|c|c|}
\hline Basis & $\$ M M$ \\
\hline Discrete Estimates & 3.4 \\
\hline Discrete Estimates & 11.1 \\
\hline Discrete Estimates & 5.5 \\
\hline Discrete Estimates & 7.3 \\
\hline Discrete Estimates & 6.3 \\
\hline Discrete Estimates & 13.6 \\
\hline Discrete Estimates & 8.9 \\
\hline Discrete Estimates & 15.4 \\
\hline Discrete Estimates & 1.6 \\
\hline Discrete Estimates & 5.0 \\
\hline Discrete Estimates & 22.5 \\
\hline Discrete Estimates & 8.8 \\
\hline Discrete Estimates & 10.7 \\
\hline Discrete Estimates & 1.3 \\
\hline Discrete Estimates & 10.1 \\
\hline Discrete Estimates & 36.4 \\
\hline Discrete Estimates & 10.3 \\
\hline Discrete Estimates & 2.9 \\
\hline Allocation & 5.0 \\
\hline \multirow{2}{*}{ Allocation } & 25.0 \\
\hline & $\overline{211.2}$ \\
\hline $5 \%$ of Directs & 10.6 \\
\hline $8 \%$ of Directs & 16.9 \\
\hline $10 \%$ of Directs & 21.1 \\
\hline \multirow[t]{3}{*}{$5 \%$ of Directs } & 10.6 \\
\hline & $\overline{59.1}$ \\
\hline & 270.3 \\
\hline $0 \%$ of Directs+Indirects & 27.0 \\
\hline Fixed Capital & $\overline{297.3}$ \\
\hline
\end{tabular}

\begin{tabular}{cr}
45 Days of Revenue & 297.3 \\
$5 \%$ of Fixed Capital & 19.7 \\
Total Capital & 14.9 \\
\cline { 2 - 2 } Fixed Capital, \$/Annual Gal & 331.9 \\
\hline
\end{tabular}

Lange Factor, Uncorrected for Skids $\quad 2.38$ 
Table 3 - Detailed Fixed Capital

\begin{tabular}{|c|c|c|c|c|c|c|c|c|c|}
\hline Area & Tag & Name & Description & $\begin{array}{c}\text { Design } \mathrm{T}, \\
\mathrm{F}\end{array}$ & $\begin{array}{c}\text { Design } P, \\
\text { psig }\end{array}$ & $\begin{array}{c}\begin{array}{c}\text { Materials } \\
\text { of } \\
\text { Construction }\end{array} \\
\end{array}$ & $\begin{array}{c}\text { Purchased } \\
\text { Equipment, \$ } \\
\text { (CE Index = 450) } \\
\end{array}$ & $\begin{array}{l}\text { Installation } \\
\text { Factor, } \\
\text { Directs } \\
\end{array}$ & $\begin{array}{c}\text { Direct } \\
\text { Installed } \\
\text { Cost, } \$\end{array}$ \\
\hline \multirow{22}{*}{ Feed Prep } & A-1001 & Mineral Solution Tank Agitator & Turbine, $5 \mathrm{Hp}$ & & & cS & 30,877 & 1.20 & 37,052 \\
\hline & A-1002 & Reductant Tank Agitator & Turbine, $2.5 \mathrm{Hp}$ & & & CS & 21,260 & 1.20 & 25,512 \\
\hline & A-1005 & СaCO3 Slurry Tank Agitator & Turbine, $300 \mathrm{Hp}$ & & & CS & 292,412 & 1.20 & 350,894 \\
\hline & $\mathrm{E}-1000$ & Heat Sterilizer Cross Exchanger & Shell \& Tube, $32057 \mathrm{ft} 2$ (NEU) & 400 & Shell: 100 Tube: 100 & CS & 397,441 & 2.60 & $1,033,347$ \\
\hline & $\mathrm{E}-1001$ & Heat Sterilzer Trim Heater & Shell \& Tube, $2869 \mathrm{ft}$ (NEU) & 400 & Shell: 100 Tube: 100 & CS & 61,767 & 2.60 & 160,594 \\
\hline & E-1002 & Sugars-Broth Cross Exchanger & Shell \& Tube, $11464 \mathrm{ft} 2$ (NEU) & 400 & Shell: 50 Tube: 50 & CS & 168,229 & 2.60 & 437,395 \\
\hline & E-1003 & Sugars Trim Heater & Shell \& Tube, $63 \mathrm{ft2}$ (NEU) & 400 & Shell: 100 Tube: 50 & CS & 7,634 & 2.60 & 19,848 \\
\hline & $\mathrm{F}-1000$ & Filter Sterilizer & Cartridge (Spared) & 400 & 50 & CS & 88,976 & 2.75 & 244,684 \\
\hline & P-1000 & Starch Hydrolyzate Pump & 801 gpm @ 75' TDH, Centrifugal (Spared) & & & CS & 14,526 & 2.65 & 38,494 \\
\hline & P-1001 & Mineral Solution Pump & $19 \mathrm{gpm} @ 64^{\prime} \mathrm{TDH}$, Centrifugal (Spared) & & & CS & 5,028 & 2.65 & 13,324 \\
\hline & P-1002 & Reductant Pump & $3 \mathrm{gpm} @ 64$ 'TDH, Centrifugal (Spared) & & & CS & 4,866 & 2.65 & 12,895 \\
\hline & P-1003 & Fermentation Water Pump & 1877 gpm @ 68' TDH, Centrifugal (Spared) & & & CS & 23,204 & 2.65 & 61.491 \\
\hline & P-1004 & Light Steep Water Pump & 708 gpm @ 133' TDH, Centrifugal (Spared) & & & CS & 15,394 & 2.65 & 40,794 \\
\hline & P-1005 & СaCO3 Slurry Pump & 238 gpm @ 92' TDH, Centrifugal (Spared) & & & cs & 7,168 & 2.65 & 18,995 \\
\hline & $\mathrm{T}-1000$ & Starch Hydrolyzate Tank & Atmospheric Tank, $1 @$ 200,000 gal & & & CS & 119,663 & 1.65 & 197,444 \\
\hline & $\mathrm{T}-1001$ & Mineral Solution Tank & Atmospheric Tank, $1 @$ 10,000 gal & & & CS & 31,059 & 1.65 & 51,247 \\
\hline & $\mathrm{T}-1002$ & Reductant Tank & Atmospheric Tank, $1 @$ 5,000 gal & & & CS & 17,245 & 1.65 & 28,454 \\
\hline & $\mathrm{T}-1003$ & Fermentation Water Tank & Atmospheric Tank, $1 @ 450,000$ gal & & & CS & 213,800 & 1.65 & 352,770 \\
\hline & T-1004 & Light Steep Water Tank & Atmospheric Tank, $1 @ 170,000$ gal & & & CS & 103,403 & 1.65 & 170,615 \\
\hline & $\mathrm{T}-1005$ & CaCO3 Slurry Tank & Atmospheric Tank, $1 @$ @ 60,000 gal & & & CS & 59,868 & 1.65 & 98,782 \\
\hline & $x-1000$ & Sterilizer & Trombone Pipe, Included in piping costs & & & CS & & 2.75 & 0 \\
\hline & & & & & & Subtotal ${ }^{-}$ & $1,683,820$ & Subtotal & $3,394,633$ \\
\hline \multirow[t]{5}{*}{ Fermentation } & $\mathrm{T}-1100$ & Fermentor & Atmospheric Tank, $10 @ 1,000,000 \mathrm{gal}$ & & & cs & $6,070,860$ & 1.65 & $10,016,919$ \\
\hline & P-1100 & Cell Mass Pump & 82 gpm @ 212' TDH, Centrifugal (Spared) & & & CS & 7,548 & 2.65 & 20,002 \\
\hline & $\mathrm{x}-1100$ & Clarifier & $4064 \mathrm{gpm}$ & & & CS & 500,000 & 2.10 & $1,050,000$ \\
\hline & $\mathrm{X}-1101$ & Homogenizer & Included in Above & & & CS & & 2.75 & \\
\hline & & & & & & Subtotal & $6,578,408$ & Subtotal & $11,086,921$ \\
\hline \multirow{5}{*}{ Pre-Concentration } & P-1201 & Permeate Pump & 1555 gpm @ 24' TDH, Centrifugal (Spared) & & & CS & 18,944 & 2.65 & 50,202 \\
\hline & $\mathrm{T}-1200$ & Clarified Broth Tank & Atmospheric Tank, $1 @ 1,000,000 \mathrm{gal}$ & & & CS & 607,086 & 1.65 & $1,001,692$ \\
\hline & $\mathrm{T}-1201$ & Permeate Tank & Atmospheric Tank, $1 @ 375,000$ gal & & & CS & 209,938 & 1.65 & 346,398 \\
\hline & $\mathrm{X}-1200$ & Reverse Osmosis Unit & $22,799 \mathrm{~m} 2$ & & & CS & $1,644,207$ & 2.50 & $4,110,518$ \\
\hline & & & & & & Subtotal ${ }^{-}$ & $2,480,175$ & Subtotal & $5,508,809$ \\
\hline \multirow[t]{14}{*}{ Acidification } & C-1300 & Rich Stripping Gas Blower & $5376 \mathrm{Hp}$ & & & CS & $1,369,541$ & 1.40 & $1,917,357$ \\
\hline & C-1301 & Lean Stripping Gas Blower & $1940 \mathrm{Hp}$ & & & CS & 605,860 & 1.40 & 848,204 \\
\hline & $E-1300$ & Broth Cooler & Shell \& Tube, 6795 ft2 (BEM) & 400 & Shell: 50 Tube: 100 & CS & 101,100 & 2.60 & 262,860 \\
\hline & $\mathrm{E}-1301$ & Lean Stripping Gas Air Cooler & Forced Draft Air Fin, $9942 \mathrm{ft} 2$ (Bare) & 400 & 50 & CS & 214,514 & 2.60 & 557,736 \\
\hline & $E-1302$ & Lean Stripping Gas Water Cooler & Shell \& Tube, 6919 ft2 (BEM) & 400 & Shell: 50 Tube: 100 & CS & 103,892 & 2.60 & 270,119 \\
\hline & $E-1303$ & Wash Water Heater & Shell \& Tube, $527 \mathrm{ft} 2$ (NEU) & 400 & Shell: 50 Tube: 100 & Cs & 21,791 & 2.60 & 56,657 \\
\hline & $\mathrm{P}-1300$ & TBA Pump & $928 \mathrm{gpm} @ 60^{\prime} \mathrm{TDH}$, Centrifugal (Spared) & & & cs & 14,528 & 2.65 & 38,499 \\
\hline & $\mathrm{T}-1300$ & TBA Tank & Atmospheric Tank, $1 @ 225,000$ gal & & & CS & 119,663 & 1.65 & 197,444 \\
\hline & $V-1300$ & Rich Stripping Gas KO Drum & 21'0" ID x 15"6" TT, Vertical w/ Pad & 400 & 50 & CS & 124,744 & 2.75 & 343,046 \\
\hline & V-1301 & Lean Stripping Gas KO Drum & $177^{\prime} 6 "$ ID x 13'6" TT, Vertical w/ Pad & 400 & 50 & CS & 95,523 & 2.75 & 262,688 \\
\hline & V-1302 & Acidifier & $22^{\prime} 0 "$ ID x 38'0" TT, 10 Trays & 400 & 50 & CS & 353,032 & 2.10 & 741,367 \\
\hline & $\mathrm{V}-1303$ & Lime Scrubber & $24^{\prime} 0^{\prime \prime}$ ID x 48'0" TT, Packed & 400 & 50 & cs & 531,600 & 2.10 & $1,116,360$ \\
\hline & $\mathrm{X}-1300$ & Filter & Rotary Drum, $12^{\prime} 0^{\prime \prime}$ ID x 20'0" TT & & & cs & 296,173 & 2.40 & 710,815 \\
\hline & & & & & & Subtotal ${ }^{-}$ & $3,951,961$ & Subtotal & $7,323,153$ \\
\hline \multirow[t]{6}{*}{ Extraction } & P-1400 & Aqueous Feed Pump & 3366 gpm @ 24' TDH, Centrifugal (Spared) & & & cs & 23,876 & 2.65 & 63,271 \\
\hline & P-1401 & Solvent Feed Pump & 2604 gpm @ 29' TDH, Centrifugal (Spared) & & & cS & 24,544 & 2.65 & 65,042 \\
\hline & $\mathrm{T}-1400$ & Aqueous Feed Tank & Atmospheric Tank, $1 @$ @ 800,000 gal & & & CS & 408,168 & 1.65 & 673,477 \\
\hline & $\mathrm{T}-1401$ & Solvent Feed Tank & Atmospheric Tank, $1 @ 625,000$ gal & & & CS & 304,362 & 1.65 & 502,197 \\
\hline & $V-1400$ & Extractor & RDC, 9 Theoretical Stages & 400 & 50 & & $2,380,952$ & 2.10 & $5,000,000$ \\
\hline & & & & & & Subtotal ${ }^{-}$ & $3,141,902$ & Subtotal & $6,303,988$ \\
\hline Esterification+Fraction & E-1500 & Extract-TBA Cross Exchanger & Shell \& Tube, $4448 \mathrm{ft} 2$ (NEU) & 400 & Shell: 50 Tube: 100 & cS & 84,552 & 2.60 & 219,835 \\
\hline
\end{tabular}


DE-FG36-03GO13010

ZeaChem, Inc.

\begin{tabular}{|c|c|c|c|}
\hline & E-1501 & Extract-Bottoms Cross Exchanger & Shell \& Tube, 15870 ft2 (NEU) \\
\hline & E-1502 & Bottoms Cooler & Shell \& Tube, $1592 \mathrm{ft} 2$ (BEM) \\
\hline & E-1503 & Esterifier Reboiler & Shell \& Tube, $47683 \mathrm{ft} 2$ (NEU) \\
\hline & E-1504 & TBA Splitter Reboiler & Shell \& Tube, 56440 ft2 (NEU) \\
\hline & E-1505 & TBA Splitter Condenser & Shell \& Tube, $36772 \mathrm{ft} 2$ (BEM) \\
\hline & E-1506 & Esterifier Overhead Air Cooler & Forced Draft Air Fin, $23532 \mathrm{ft} 2$ (Bare) \\
\hline & E-1507 & Esterifier Overhead Water Cooler & Shell \& Tube, $4752 \mathrm{ft} 2$ (BEM) \\
\hline & E-1508 & TBA Cooler & Shell \& Tube, $1699 \mathrm{ft} 2$ (BEM) \\
\hline & P-1500 & Extract Feed Pump & 3987 gpm @ 112' TDH, Centrifugal (Spared) \\
\hline & P-1501 & Extract Water Pump & 179 gpm @ 36' TDH, Centrifugal (Spared) \\
\hline & P-1502 & Ester Pump & 2094 gpm @ 69' TDH, Centrifugal (Spared) \\
\hline & P-1503 & TBA Pump & 1004 gpm @ 109' TDH, Centrifugal (Spared) \\
\hline & $T-1500$ & Extract Tank & Atmospheric Tank, $1 @ 1,000,000$ \\
\hline & V-1500 & Esterifier Column & $4 @ 13^{\prime} 0^{\prime \prime ~ I D ~ x ~ 44 ' 0 " ~ T T, ~} 14$ Bubble Cap Trays \\
\hline & $\mathrm{V}-1501$ & Esterifier Reactor & Included in V-1500 \\
\hline & V-1502 & Esterifier Overhead Drum & 11'6" ID x 34'6" TT, Horizontal \\
\hline & V-1503 & TBA Splitter & $2 @ 29^{\prime} 6 "$ ID x 56'0" TT, Packed \\
\hline & V-1504 & TBA Splitter Reflux Drum & $11^{\prime} 6 "$ ID x 34'6" TT, Horizontal \\
\hline Water Management & A-1600 & Water Stripper Feed Tank Agitator & Turbine, $150 \mathrm{Hp}$ \\
\hline & E-1600 & Feed-Bottoms Cross Exchanger & Shell \& Tube, 90372 ft2 (NEU) \\
\hline & E-1601 & Feed Trim Heater & Shell \& Tube, 2186 ft2 (NEU) \\
\hline & E-1602 & Water Stripper Reboiler & Shell \& Tube, $16439 \mathrm{ft} 2$ (NEU) \\
\hline & E-1603 & Water Stripper Overhead Air Cooler & Forced Draft Air Fin, $12838 \mathrm{ft}$ (Bare) \\
\hline & E-1604 & Water Stripper Overhead Water Cooler & Shell \& Tube, 602 ft2 (BEM) \\
\hline & P-1600 & Water Stripper Feed Pump & 2492 gpm @ 82' TDH, Centrifugal (Spared) \\
\hline & P-1601 & Stripped Water Pump & 2406 gpm @ 70' TDH, Centrifugal (Spared) \\
\hline & P-1602 & Permeate Pump & 579 gpm @ 24' TDH, Centrifugal (Spared) \\
\hline & P-1603 & Solvent Pump & 34 gpm @ 29' TDH, Centrifugal (Spared) \\
\hline & $T-1600$ & Water Stripper Feed Tank & Atmospheric Tank, $1 @ 600,000$ gal \\
\hline & T-1601 & Stripped Water Tank & Atmospheric Tank, $1 @ 600,000$ gal \\
\hline & T-1602 & Permeate Tank & Atmospheric Tank, $1 @ 140,000 \mathrm{gal}$ \\
\hline & V-1600 & Water Stripper & 9'0" ID x 41'0" TT, 14 Trays \\
\hline & V-1601 & Water Stripper Reflux Drum & 5'0" ID x 15'0" TT, Horizontal \\
\hline & $\mathrm{x}-1600$ & Reverse Osmosis Unit & $6202 \mathrm{~m} 2$ \\
\hline Hydrogenolysis & C-1700 & Recycle Compressor & $2275 \mathrm{Hp}$, Centrifugal \\
\hline & C-1701 & Vacuum Pump & $4 \mathrm{Hp}$, Liquid Ring \\
\hline & C-1702 & Refrigeration Compressor & $349 \mathrm{Hp}$, Centrifugal, Included in X-1700 \\
\hline & E-1701 & Feed-Crude Product Cross Exchanger & Shell \& Tube, $81439 \mathrm{ft} 2$ (NEU) \\
\hline & E-1702 & Feed Trim Heater & Shell \& Tube, $8415 \mathrm{ft} 2$ (NEU) \\
\hline & E-1703 & Ethanol Splitter Reboiler & Shell \& Tube, $8456 \mathrm{ft} 2$ (NEU) \\
\hline & E-1704 & Product Cooler & Shell \& Tube, $17644 \mathrm{ft} 2$ (NEU) \\
\hline & E-1705 & LP KO Drum Knockback Condenser & Shell \& Tube, 8 ft2 (NEU) \\
\hline & E-1706 & Crude Product-Bottoms Cross Exchanger & Shell \& Tube, $31346 \mathrm{ft} 2$ (NEU) \\
\hline & E-1707 & Ethanol Splitter Condenser & Shell \& Tube, $52524 \mathrm{ft} 2$ (BEM) \\
\hline & E-1708 & Ethanol Splitter Knockback Condenser & Shell \& Tube, 96 ft2 (NEU) \\
\hline & E-1709 & Bottoms Cooler & Shell \& Tube, 4225 ft2 (BEM) \\
\hline & E-1710 & Refrigerant Cooler & Shell \& Tube, $1109 \mathrm{ft} 2$ (BEM), Included in X-17 \\
\hline & P-1700 & Ester Feed Pump & 2094 gpm @ 570' TDH, Centrifugal (Spared) \\
\hline & P-1701 & Neat EtOH Pump & 196 gpm @ 64' TDH, Centrifugal (Spared) \\
\hline & P-1702 & Bottoms Pump & 2046 gpm @ 94' TDH, Centrifugal (Spared) \\
\hline & T-1700 & Ester Feed Tank & Atmospheric Tank, $1 @ 500,000$ gal \\
\hline & V-1700 & Hydrogenolysis Reactor & $\mathrm{g}^{\prime} 0 " \mathrm{TT}$, Vertical \\
\hline & $\mathrm{V}-1700$ & Initial Catalyst Charge for V-1700 & $9765 \mathrm{ft} 3$ Reduced CuO/ZnO \\
\hline & V-1701 & HP KO Drum & $11^{\prime} 0 "$ ID X 33'0" TT, Vertical w/ Pad \\
\hline & V-1702 & LP KO Drum & 11'0" ID X 33'0" TT, Vertical w/ Pad \\
\hline & V-1703 & Ethanol Splitter & 18'0" ID x 42'0" TT, Packed \\
\hline & V-1704 & Ethanol Splitter Reflux Drum & $8^{\prime} 0^{\prime \prime ~ I D ~} \times 24^{\prime} 0^{\prime \prime} \mathrm{TT}$, Horizontal \\
\hline & V-1705 & Refrigerant Receiver & Included in X-1700 \\
\hline & V-1706 & Refrigerant KO Drum & Included in X-1700 \\
\hline & $\mathrm{x}-1700$ & Refrigeration Skid & 94 tons @ -31 F, Propane Refrigerant \\
\hline
\end{tabular}

$\begin{array}{cc}400 & \text { Shell: } 100 \text { Tube: } 100 \\ 400 & \text { Shell: } 100 \text { Tube: } 100 \\ 400 & \text { Shell: } 100 \text { Tube: } 350 \\ 400 & \text { Shell: } 100 \text { Tube: } F V / 50 \\ 400 & \text { Shell: FV FV Tube: } 100 \\ 400 & 100 \\ 400 & \text { Shell: } 50 \text { Tube: } 100 \\ 400 & \text { Shell: } 50 \text { Tube: } 100 \\ & \\ & \\ & \\ 400 & 50 \\ 400 & 50 \\ 400 & 50 \\ 400 & \text { FV/50 } \\ 400 & \text { FV/50 } \\ & \end{array}$

400

400
400

400
400

400

Shell: 100 Tube: 100
Shell: 100 Tube: 100
Shell: 100 Tube: 100
100
Shell: 50 Tube: 100

50
50

$\begin{array}{ll} & \\ & \\ 450 & \text { Shell: } 250 \text { Tube: } 250 \\ 450 & \text { Shell: } 350 \text { Tube: } 250 \\ 450 & \text { Shell: } 250 \text { Tube: } F V / 50 \\ 400 & \text { Shell: } 100 \text { Tube: } 250 \\ 400 & \text { Shell: } 50 \text { Tube: } 50 \\ 400 & \text { Shell: } 50 \text { Tube: } F V / 50 \\ 400 & \text { Shell: FV/50 Tube: } 100 \\ 400 & \text { Shell: } 50 \text { Tube: } F V / 50 \\ 400 & \text { Shell: } 50 \text { Tube: } 100 \\ 400 & \text { Shell: } 300 \text { Tube: } 100\end{array}$

$\begin{array}{cc}450 & 250 \\ 400 & 250 \\ 400 & 50 \\ 400 & \mathrm{FV} / 50 \\ 400 & \mathrm{FV} / 50 \\ 400 & 300 \\ 400 & 50\end{array}$
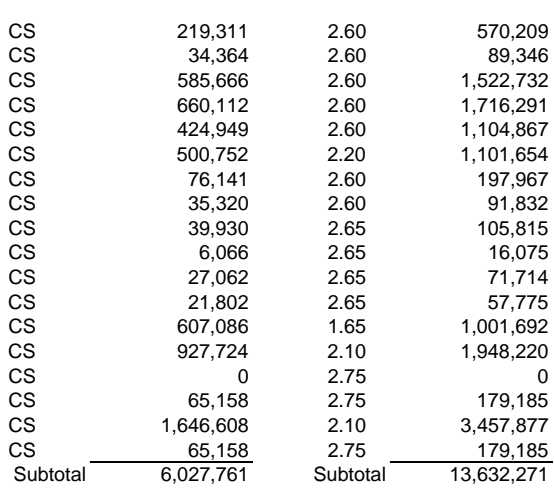

$\begin{array}{lr}\text { CS } & 144,560 \\ \text { CS } & 1,026,876 \\ \text { CS } & 52,534 \\ \text { CS } & 226,961 \\ \text { CS } & 276,654 \\ \text { CS } & 19,272 \\ \text { CS } & 32,916 \\ \text { CS } & 30,290 \\ \text { CS } & 10,534 \\ \text { CS } & 4,890 \\ \text { CS } & 317,474 \\ \text { CS } & 317,474 \\ \text { CS } & 97,827 \\ \text { CS } & 130,700 \\ \text { CS } & 14,158 \\ \text { CS } & 1,165,311 \\ \text { Subtotal } & 3,868,431\end{array}$

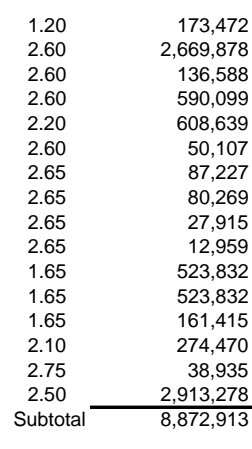

$\begin{array}{lr}\text { CS } & 688,387 \\ \text { CS } & 22,693 \\ \text { CS } & 0 \\ \text { CS } & 983,014 \\ \text { CS } & 143,139 \\ \text { CS } & 135,405 \\ \text { CS } & 250,057 \\ \text { CS } & 7,068 \\ \text { CS } & 387,035 \\ \text { CS } & 586,799 \\ \text { CS } & 7,953 \\ \text { CS } & 69,816 \\ \text { CS } & 0 \\ \text { CS } & 44,260 \\ \text { CS } & 6,284 \\ \text { CS } & 32,916 \\ \text { CS } & 240,516 \\ \text { CS } & 450,696 \\ \text { CS } & 2,831,850 \\ \text { CS } & 146,959 \\ \text { CS } & 62,359 \\ \text { CS } & 322,107 \\ \text { CS } & 38,995 \\ \text { CS } & 0 \\ \text { CS } & 0 \\ \text { CS } & 915,834 \\ \text { Subtol } & 8374,142\end{array}$

$1,032,581$
24,962

$2,555,836$

372,161

352,053
650,148

18,377

$1,006,291$
$1,525,677$

$1,525,667$
20,678

181,522
0

117,289

16,653
87,227

396,851

$1,239,414$
$3,115,035$

404,137
171,487

171,487
676,425

676,425
107,236

94 tons @ -31 F, Propane Refrigeran 
DE-FG36-03GO13010

ZeaChem, Inc.

\begin{tabular}{|c|c|c|c|}
\hline \multirow[t]{9}{*}{ Denaturing } & $\mathrm{F}-1800$ & Product Filter & Cartridge (Spared) \\
\hline & P-1800 & Neat EtOH Pump & 196 gpm @ 30' TDH, Centrifugal (Spared) \\
\hline & P-1801 & Natural Gasoline Pump & 10 gpm @ 34' TDH, Centrifugal (Spared) \\
\hline & P-1802 & Inhibitors Pump & 100 gphr @ 29' TDH, Metering (Spared) \\
\hline & P-1803 & Denatured EtOH Pump & 206 gpm @ 45' TDH, Centrifugal (Spared) \\
\hline & $T-1800$ & Neat EtOH Tank & Atmospheric Tank, $1 @ 300,000 \mathrm{gal}$ \\
\hline & $\mathrm{T}-1801$ & Natural Gasoline Tank & Atmospheric Tank, $1 @ 30,000 \mathrm{gal}$ \\
\hline & T-1802 & Inhibitors Tank & Atmospheric Tank, $1 @ 500 \mathrm{gal}$ \\
\hline & $\mathrm{T}-1803$ & Denatured EtOH Tank & Atmospheric Tank, $5 @ 300,000$ gal \\
\hline Feed Handling & $x-2000$ & Area Allocation & Area Allocation \\
\hline \multirow{14}{*}{ Gasification } & C-2100 & Combustor Air Blower & Included in X-2109 \\
\hline & $\mathrm{E}-2101$ & Combustor Offgas Heat Recovery & Included in X-2109 \\
\hline & $V-2100$ & Gasifier & Included in X-2109 \\
\hline & $V-2101$ & Combustor & Included in X-2109 \\
\hline & $\mathrm{X}-2100$ & Feeder & Included in X-2109 \\
\hline & $\mathrm{x}-2101$ & Gasifier Primary Cyclone & Included in X-2109 \\
\hline & $\mathrm{X}-2102$ & Gasifier Secondary Cyclone & Included in X-2109 \\
\hline & $\mathrm{X}-2103$ & Combustor Primary Cyclone & Included in X-2109 \\
\hline & $\mathrm{x}-2104$ & Combustor Secondary Cyclone & Included in X-2109 \\
\hline & $x-2105$ & Electrostatic Precipitator & Included in X-2109 \\
\hline & $x-2106$ & Ash Cooler & Included in X-2109 \\
\hline & $\mathrm{X}-2107$ & Ash Blender & Included in X-2109 \\
\hline & $\mathrm{X}-2108$ & Combustor Offgas Expander & Included in X-2109 \\
\hline & & Area Allocation & Area Allocation \\
\hline \multirow[t]{16}{*}{ Conditioning } & C-2200 & Regenerator Air Blower & Included in X-2203 \\
\hline & $E-2200$ & Conditioned Gas Heat Recovery & Included in X-2203 \\
\hline & $\mathrm{E}-2201$ & Conditioned Gas Water Cooler & Included in X-2203 \\
\hline & $\mathrm{E}-2202$ & Conditioning Water Cooler & Included in X-2203 \\
\hline & $\mathrm{E}-2203$ & Included in V-2202 & Included in X-2203 \\
\hline & $E-2204$ & Regen Offgas Heat Recovery & Included in X-2203 \\
\hline & $\mathrm{P}-2200$ & Conditioning Water Pump & Included in X-2203 \\
\hline & P-2201 & Solids Pump & Included in X-2203 \\
\hline & $V-2200$ & Tar Reformer & Included in X-2203 \\
\hline & $V-2200$ & Initial Catalyst Charge for V-2200 & Included in X-2203 \\
\hline & $V-2201$ & KO Drum & Included in X-2203 \\
\hline & $V-2202$ & Regenerator & Included in X-2203 \\
\hline & $x-2200$ & Clarifier & Included in X-2203 \\
\hline & $x-2201$ & Electrostatic Precipitator & Included in X-2203 \\
\hline & $x-2202$ & Regen Offgas Expander & Included in X-2203 \\
\hline & $x-2203$ & Area Allocation & Area Allocation \\
\hline \multirow[t]{10}{*}{ Compression } & $\mathrm{V}-2300$ & Syngas Compressor Suction Drum & $16^{\prime} 0 "$ ID $\times 13^{\prime} 0 " \mathrm{TT}$, Vertical w/ Pad \\
\hline & $\mathrm{C}-2300$ & Syngas Compressor & 26,993 Hp (Brake), Centrifgual \\
\hline & $\mathrm{E}-2300$ & Syngas Compressor Air Cooler & Forced Draft Air Fin, $41515 \mathrm{ft} 2$ (Bare) \\
\hline & $\mathrm{E}-2301$ & Syngas Compressor Water Cooler & Shell \& Tube, 1826 ft2 (BEM) \\
\hline & $\mathrm{P}-2300$ & Compression KO Water Pump & $100 \mathrm{gpm} @ 16^{\prime} \mathrm{TDH}$, Centrifugal (Spared) \\
\hline & V-2301a & Syngas Compressor Interstage Drum & $13^{\prime} 6 "$ ID x 11'6" TT, Vertical w/ Pad \\
\hline & $V-2301 b$ & Syngas Compressor Interstage Drum & $11^{\prime} 6 "$ ID x 10'6" TT, Vertical w/ Pad \\
\hline & $\mathrm{V}-2301 \mathrm{c}$ & Syngas Compressor Interstage Drum & $10^{\prime} 0 "$ ID x 10'0" TT, Vertical w/ Pad \\
\hline & $V-2301 d$ & Syngas Compressor Interstage Drum & 9'0" ID x 9'6" TT, Vertical w/ Pad \\
\hline & $V-2302$ & HP Gas KO Drum & 8'0" ID x 9'6" TT, Vertical w/ Pad \\
\hline \multirow[t]{2}{*}{ Bulk Desulfurization } & $E-2400$ & Bulk Desulfuration Preheater & Shell \& Tube, $50 \mathrm{ft2}$ (NEU) \\
\hline & $\mathrm{X}-2400$ & Bulk Desulfurization Unit & LO-CAT II \\
\hline
\end{tabular}

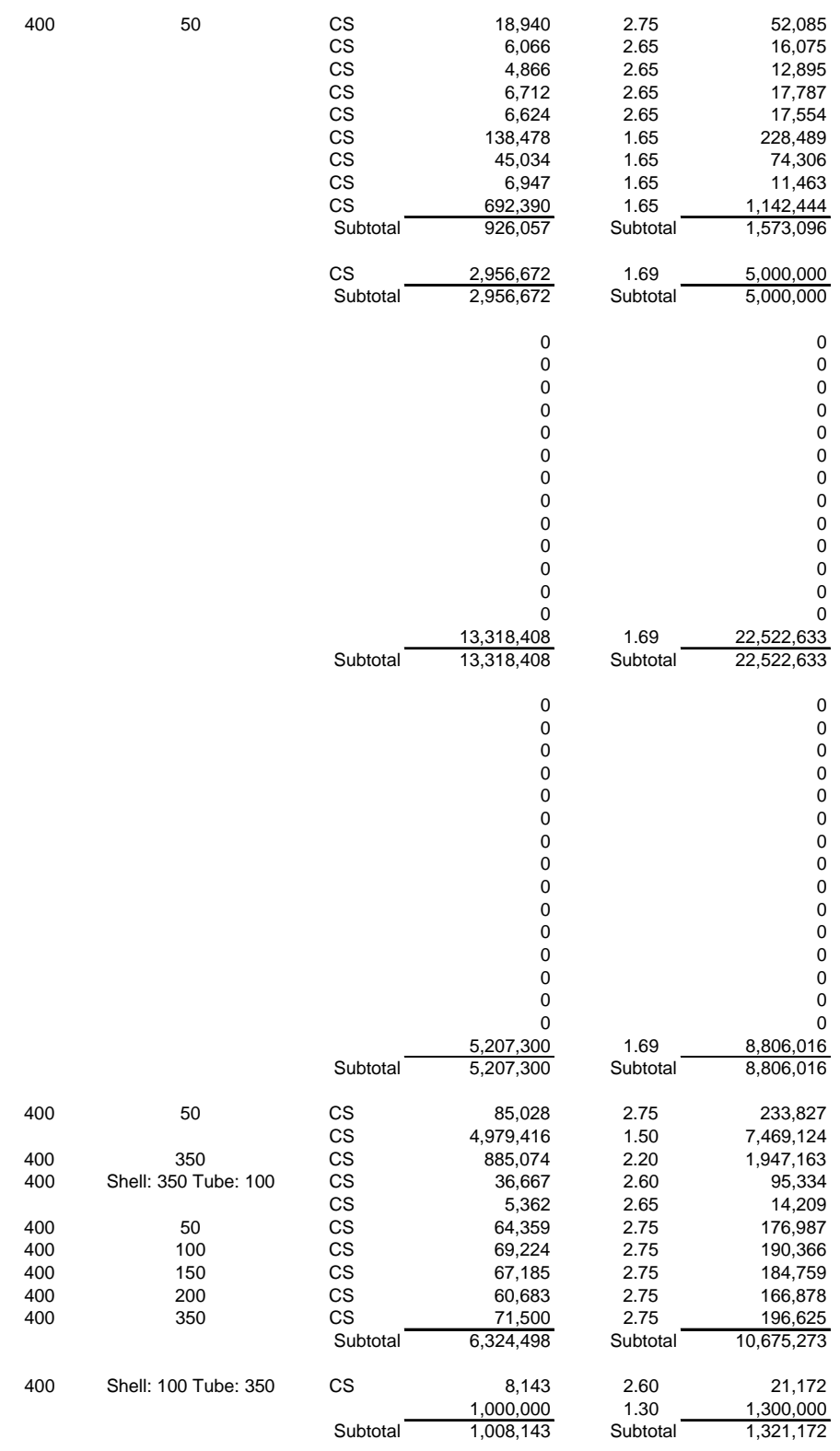


DE-FG36-03GO13010

ZeaChem, Inc.

\begin{tabular}{|c|c|c|c|}
\hline \multirow{14}{*}{ H2 Recovery } & $\mathrm{E}-2500$ & Preheater & Shell \& Tube, $1821 \mathrm{ft} 2$ (NEU) \\
\hline & $\mathrm{E}-2501$ & Heat Recovery & Shell \& Tube, $1460 \mathrm{ft} 2$ (NEU) \\
\hline & $\mathrm{E}-2502$ & Heat Recovery & Shell \& Tube, $3000 \mathrm{ft} 2$ (NEU) \\
\hline & $\mathrm{E}-2503$ & Air Cooler & Forced Draft Air Fin, $6565 \mathrm{ft2}$ (Bare) \\
\hline & E-2504 & Water Cooler & Shell \& Tube, $1192 \mathrm{ft} 2$ (BEM) \\
\hline & $\mathrm{V}-2500$ & ZnO Bed & $2 @$ 5'0" ID x 15'0" TT, Vertical \\
\hline & $\mathrm{V}-2500$ & Initial Charge for V-2500 & $450 \mathrm{ft} 3 \mathrm{ZnO}$ \\
\hline & $\mathrm{V}-2501$ & HT Shift Reactor & 8'6" ID x 25'6" TT, Vertical \\
\hline & $\mathrm{V}-2501$ & Initial Charge for V-2501 & $1447.5 \mathrm{ft} 3 \mathrm{Cr}$ Promoted Fe Oxide \\
\hline & $\mathrm{V}-2502$ & LT Shift Reactor & 7'6" ID x 22'6" TT, Vertical \\
\hline & $\mathrm{V}-2502$ & Initial Charge for V-2502 & $965 \mathrm{ft} 3$ Reduced $\mathrm{Cu}$ \\
\hline & $\mathrm{V}-2503$ & KO Drum & 6'6" ID x 9'0" TT, Vertical w/ Pad \\
\hline & $\mathrm{V}-2504$ & KO Drum & 5'6" ID x 9'6" TT, Vertical w/ Pad \\
\hline & $\mathrm{x}-2500$ & PSA Unit & 57 MMSCFD Feed @ 63\% H2, Polybed w/ 85\% Yield \\
\hline \multirow[t]{2}{*}{ Gas Turbine } & E-3000 & Heat Recovery & HRSG, $366.5 \mathrm{MMBtu} / \mathrm{hr}$ \\
\hline & $\mathrm{x}-3001$ & Gas Turbine & $68163 \mathrm{kWe}$, Includes Generator and Auxiliaries \\
\hline \multirow[t]{18}{*}{ Steam System } & $E-3100$ & Degasifier Preheater & Included in Heat Recovery \\
\hline & E-3101 & Degasifier Preheater & Included in Heat Recovery \\
\hline & E-3102 & BFW Preheater & Included in Heat Recovery \\
\hline & E-3103 & Steam Generation & Included in Heat Recovery \\
\hline & E-3104 & Superheater & Included in Heat Recovery \\
\hline & E-3105 & Blowdown Cross Exchanger & Included in Heat Recovery \\
\hline & E-3106 & $\begin{array}{l}\text { Blowdown Cooler } \\
\text { Butranger }\end{array}$ & Shell \& Tube, $290 \mathrm{ft} 2$ (BEM) \\
\hline & E-3107 & Desuperheater & Included in piping factors \\
\hline & E-3108 & Desuperheater & Included in piping factors \\
\hline & P-3100 & Make-Up Pump & 329 gpm @ 162' TDH, Centrifugal (Spared) \\
\hline & P-3101 & Condensate Pump & $258 \mathrm{gpm} @ 75^{\prime} \mathrm{TDH}$, Centrifugal (Spared) \\
\hline & P-3102 & BFW Pump & 1636 gpm @ 3193' TDH, Multistage Centrifugal (Spared) \\
\hline & P-3103 & BFW Chemicals Pump & 100 gphr @ 139' TDH, Metering (Spared) \\
\hline & $\mathrm{V}-3100$ & LP Steam Drum & $8^{\prime} 6 "$ ID x 25'6" TT, Vertical w/ Pad \\
\hline & $\mathrm{V}-3102$ & Degasifier & $17^{\prime} 0^{\prime \prime ~ I D ~} \times 51^{\prime} 0 "$ " TT, 5 Trays, vertical \\
\hline & V-3103 & HP Steam Drum & 10'6" ID x 31'6" TT, Horizontal \\
\hline & $x-3100$ & Steam Turbine & 39.2 MWe, Non-condensing \\
\hline & $\mathrm{x}-3101$ & Ion Exchange Unit & $330 \mathrm{gpm}$ \\
\hline Cooling Water & $\begin{array}{r}\text { P-4000 } \\
x \rightarrow 4000\end{array}$ & CW Circulation Pump & 49045 gpm @ 138' TDH, Centrifugal (Spared) \\
\hline & & & \\
\hline Other Utilities & $x-5000$ & Other Utilities & Allocation \\
\hline \multirow[t]{3}{*}{ Other OSBL } & $x-6000$ & Additional Tank Farm & Allocation \\
\hline & $x-7000$ & Pipe Racks & Allocation \\
\hline & $x-8000$ & Buildings & Allocation \\
\hline
\end{tabular}

$\begin{array}{cc}900 & \text { Shell: } 300 \text { Tube: } 350 \\ 550 & \text { Shell: } 300 \text { Tube: } 1450 \\ 550 & \text { Shell: } 300 \text { Tube: } 1450 \\ 400 & 300 \\ 400 & \text { Shell: } 300 \text { Tube: } 100 \\ 750 & 350 \\ & \\ 900 & 350 \\ 550 & 300 \\ & \\ 400 & 300 \\ 400 & 300\end{array}$
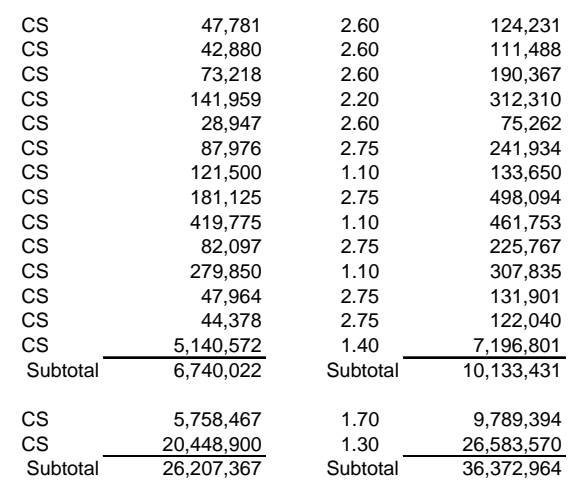

Subtota

$26,583,570$

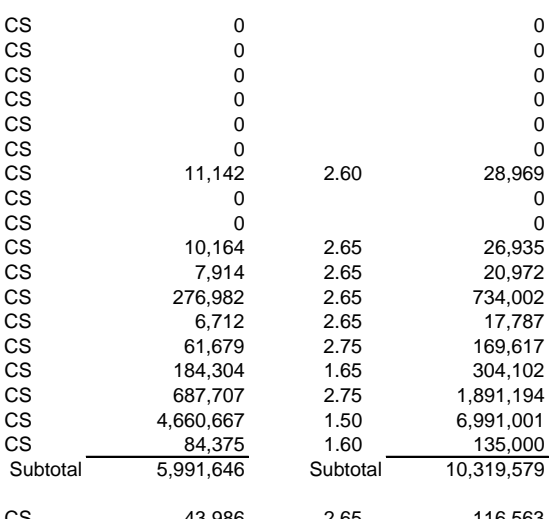

Shell: 1450 Tube: 100

100

600

1450

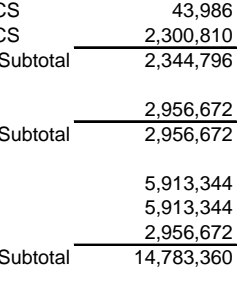

\begin{tabular}{cr}
2.65 & 116,563 \\
1.20 & $2,760,972$ \\
\cline { 2 - 2 } & $2,877,535$
\end{tabular}

$\begin{array}{cr}1.69 & 5,000,000 \\ \text { Subtotal } & 5,000,000\end{array}$

$\begin{array}{ll}1.69 & 10,000,000 \\ 1.69 & 10,000,000\end{array}$

$\begin{array}{cr}1.69 & 5,000,000 \\ \text { Subtotal } & 25,000,000\end{array}$

$124,871,541$

Total

$211,170,177$ 


\section{Table 4 - Operating Costs}

Variable

Raw Materials

Starch Hydrolyzate, lb(dry) Stover, metric ton(dry) Light Steep Water, US nert Gas, US ton $\mathrm{CO} 2$, US ton

Fresh Solvent,

Fresh TBA, lb

Minerals, US To

Reductant, Ib

Fresh Water, $1000 \mathrm{gal}$

Make-Up Sand, US ton

MgO, US Ton

Inhibitors, lb

BFW Chemicals, Ib

Catalys

Hydrogenolysis

Chelated Iron Solution, metric ton $\mathrm{S}$

$\mathrm{ZnO}$

HT Shift

Disposa

Ash, US ton

Adsorbed Sulfur, US ton

Bulk Sulfur

Solids, US ton

Water Out, 1000 gal

Fresh $\mathrm{CaCO} 3$

Operating Labor w/ Overheads

er @ $0.5 \%$ of Fixed Capital per year

\begin{tabular}{c} 
\$/Unit \\
\hline 0.05 \\
30 \\
130 \\
1.00 \\
100 \\
100 \\
0.70 \\
1.43 \\
100 \\
100 \\
0.305 \\
1.00 \\
175 \\
365 \\
1.00 \\
1.00 \\
1.40
\end{tabular}

$\longrightarrow$

Unithr
110500.4338
118.2779344
10.49124576
571.6109716
0.012220409
0.316876863
162
33
1.064990336
0.516122925
187
135.3297046
1.4972947
0.098400408
5
5
5

\begin{tabular}{rrr} 
& & $\$ / h r$ \\
\cline { 3 - 3 } & & \\
$5,525.02$ \\
38 & & $3,548.34$ \\
44 & & $1,363.86$ \\
76 & & 571.61 \\
16 & & 1.22 \\
09 & & 31.69 \\
63 & & 113.16 \\
62 & & 46.52 \\
33 & & 106.50 \\
36 & & 51.61 \\
25 & & 5.09 \\
87 & & 135.33 \\
46 & & 262.03 \\
47 & & 35.92 \\
8 & & 5.44 \\
5 & & 4.92 \\
5 & & 7.38 \\
5 & &
\end{tabular}

0.099182073

74.79
3.00

(1)

\begin{tabular}{rr} 
& 74.79 \\
3.00 \\
14.88 \\
16.04 \\
11.09 \\
7.39 \\
\cline { 2 - 2 } Subtotal & 127.19
\end{tabular}

$20.00 \quad 10.44163195$

ZnO Purchased cos

Stockpiled

20.00
1.50

0.314029735

835

\begin{tabular}{rr}
208.83 \\
0.00 \\
0.00 \\
6.28 \\
122.26 \\
0.00 \\
0.00 \\
\cline { 2 - 2 } Subtotal \\
& 337.37 \\
& 300.00 \\
& 178.47 \\
\hline Subtotal & 478.47
\end{tabular}

ariable Costs $12,810.68$
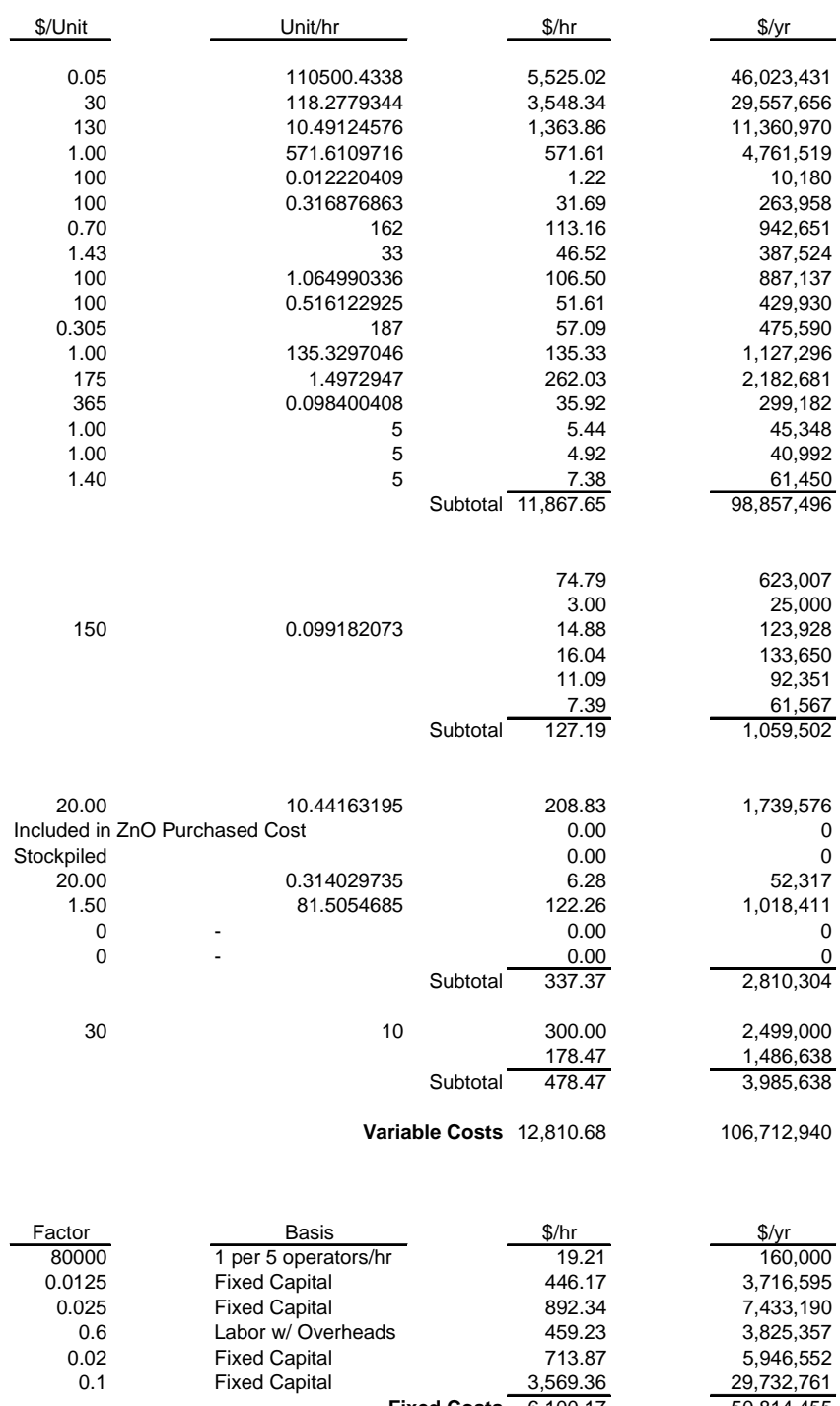

$\begin{array}{r}61,450 \\ \hline 98,857,496\end{array}$

\section{3,007}

25,000
123,928

123,928

133,650
92,351

$\begin{array}{r}61,567 \\ \hline 1,059,502\end{array}$

$1,739,576$

0
0
52,317
$1,018,411$

$1,018,411$
0

0
$2,810,304$

$2,499,000$

$\begin{array}{r}1,486,638 \\ \hline 3,985,638\end{array}$

$106,712,940$

Maintenance Supplies

Property Taxes, Insurance, etc.

Depreciation

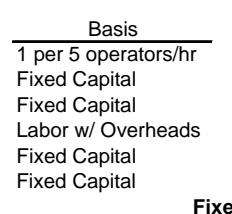

Fixed Capital

$\begin{array}{rr}\text { Fixed Costs } & 3,569.36 \\ & 6,100.17 \\ \text { Cash Costs } & 15,341.49 \\ \text { Operating Costs } & 18,910.85\end{array}$

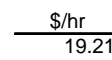

19.21

446.17
892.34

892.34
459.23 $\begin{array}{r}\multicolumn{1}{c}{\$ / y r} \\ \hline 160,000 \\ 3,716,595 \\ 7,433,190 \\ 3,825,357 \\ 5,946,552 \\ 29,732,761 \\ \hline 50,814,455\end{array}$

$127,794,635$
$157,527,396$ \$/gal

Denatured EtOI

0.4602
0.2956
0.1136

0.1136

0.0476

0.0001

0.0026

0.0094
0.0039

0.0039

0.0089

0.0043

0.0048
0.0113
0.0218

0.0113
0.0218

0.0030

0.0005

0.0004
0.0006
0.9886

0.9886

0.0062

0.0012

0.0013

0.0009

0.0006

0.0174

0.0000

0.0005

0.0102

0.0000

0.0000

0.0250

0.0149
0.0399

1.0671

\$gal

$\frac{\text { Denatured EtO }}{0.0016}$

0.0372

0.0743

0.0383
0.0595

0.2973
0.5082

1.2780 


\title{
Table 5 - Revenue Summary
}

\author{
(Real, 100\% Capacity)
}

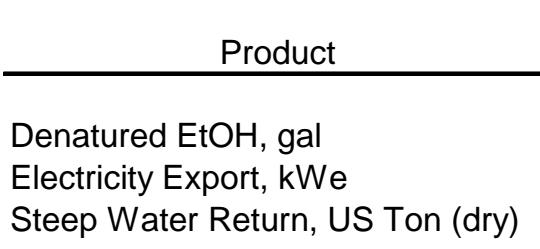

\begin{tabular}{c}
$\begin{array}{l}\text { Price, } \\
\text { \$/Unit }\end{array}$ \\
\hline \\
1.24 \\
0.05 \\
125
\end{tabular}

\begin{tabular}{r}
$\begin{array}{c}\text { Volume } \\
\text { Unit/yr }\end{array}$ \\
\hline $99,998,734$ \\
$520,822,216$ \\
140,830
\end{tabular}

$\begin{array}{r}\begin{array}{r}\text { Revenue, } \\ \$ M M / y r\end{array} \\ \hline \\ 124.0 \\ 26.0 \\ 17.6 \\ \hline \text { Total }\end{array}$

$\begin{gathered}\text { Revenue, } \\ \$ / g a l\end{gathered}$
enatured EtOH

1.2400

0.2604

0.1760

Portion of

Total

Revenue

$74.0 \%$

$15.5 \%$

$10.5 \%$ 
DE-FG36-03GO13010

ZeaChem, Inc.

\section{Table 6- Cash Flows}

Dollar Amounts in Milions

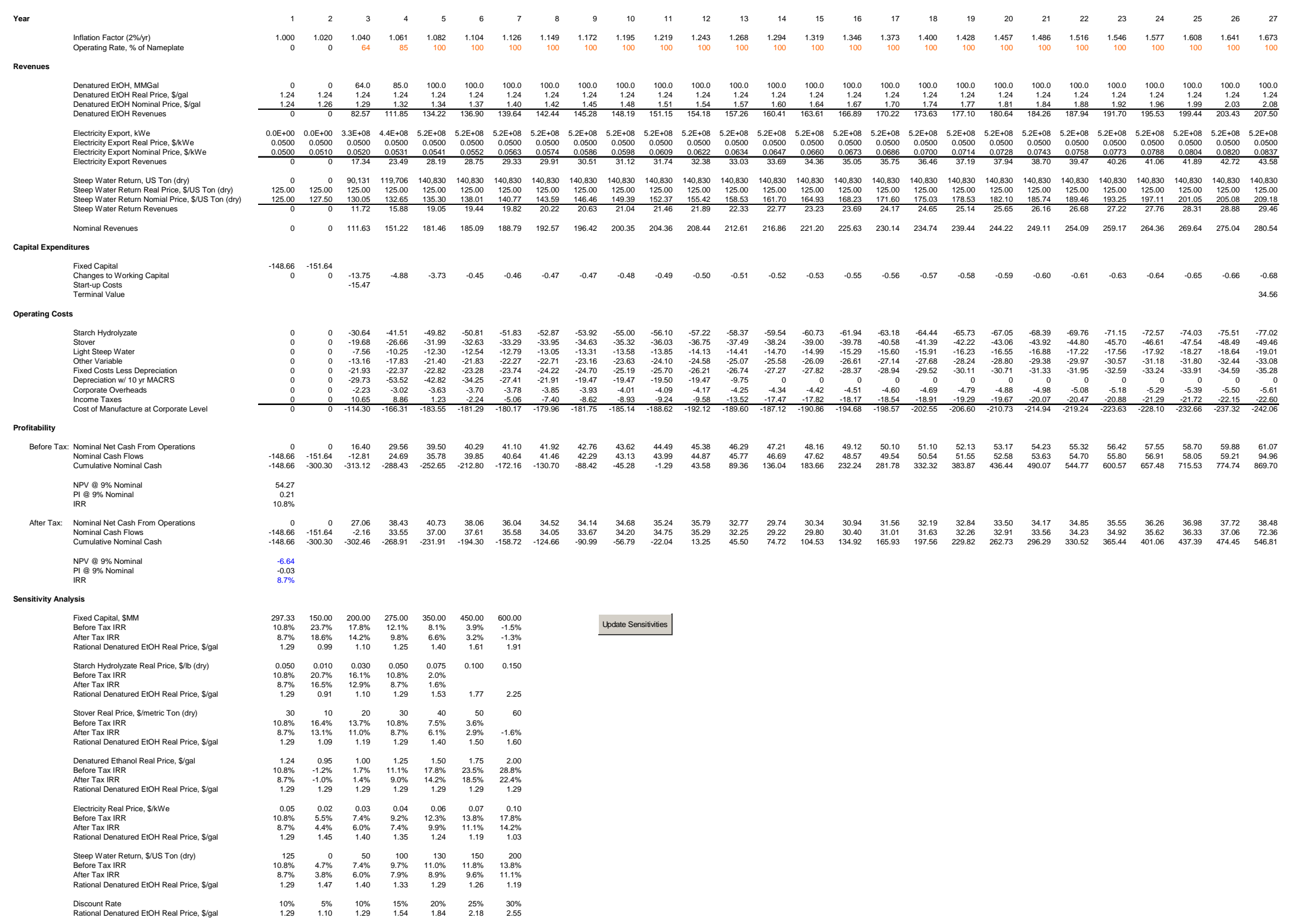


Figure 1 - Fixed Capital Breakdown

(Directs Re-grouped by Major Process Area)

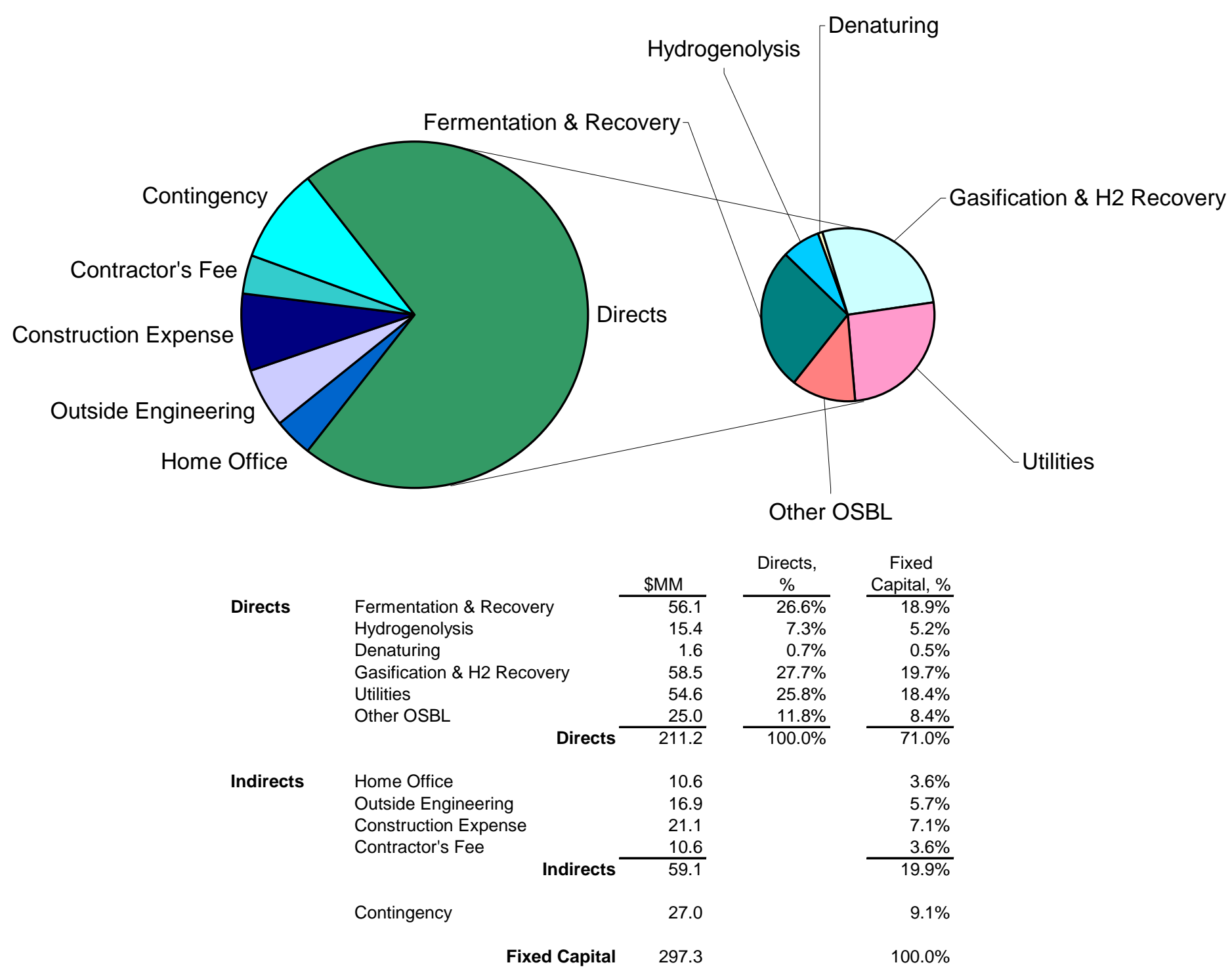


Figure 2 - Historic Contribution of Net Corn to Transfer Price of Starch Hydrolyzate

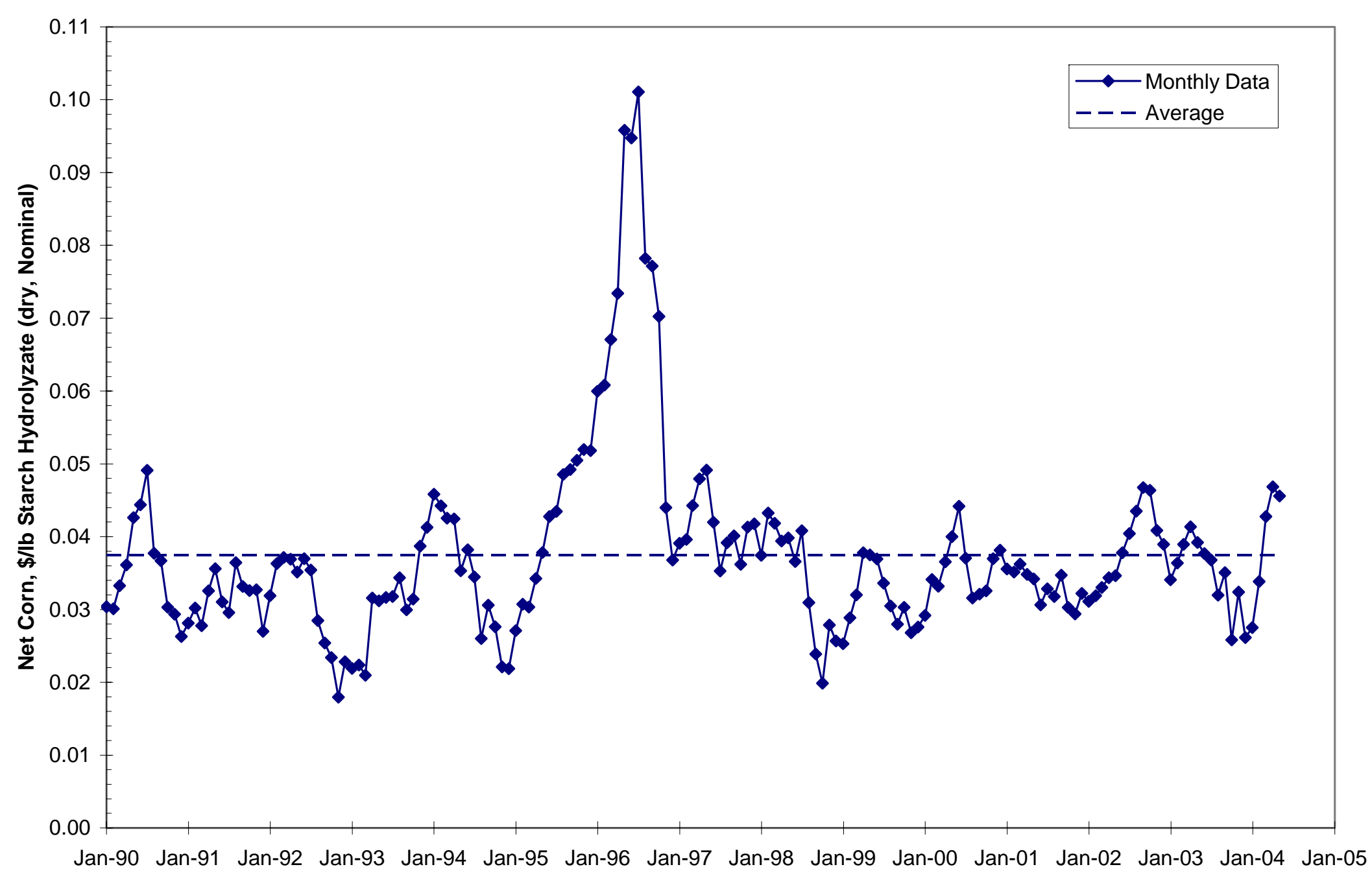


Figure 3 - Historical Prices for Fuel Ethanol

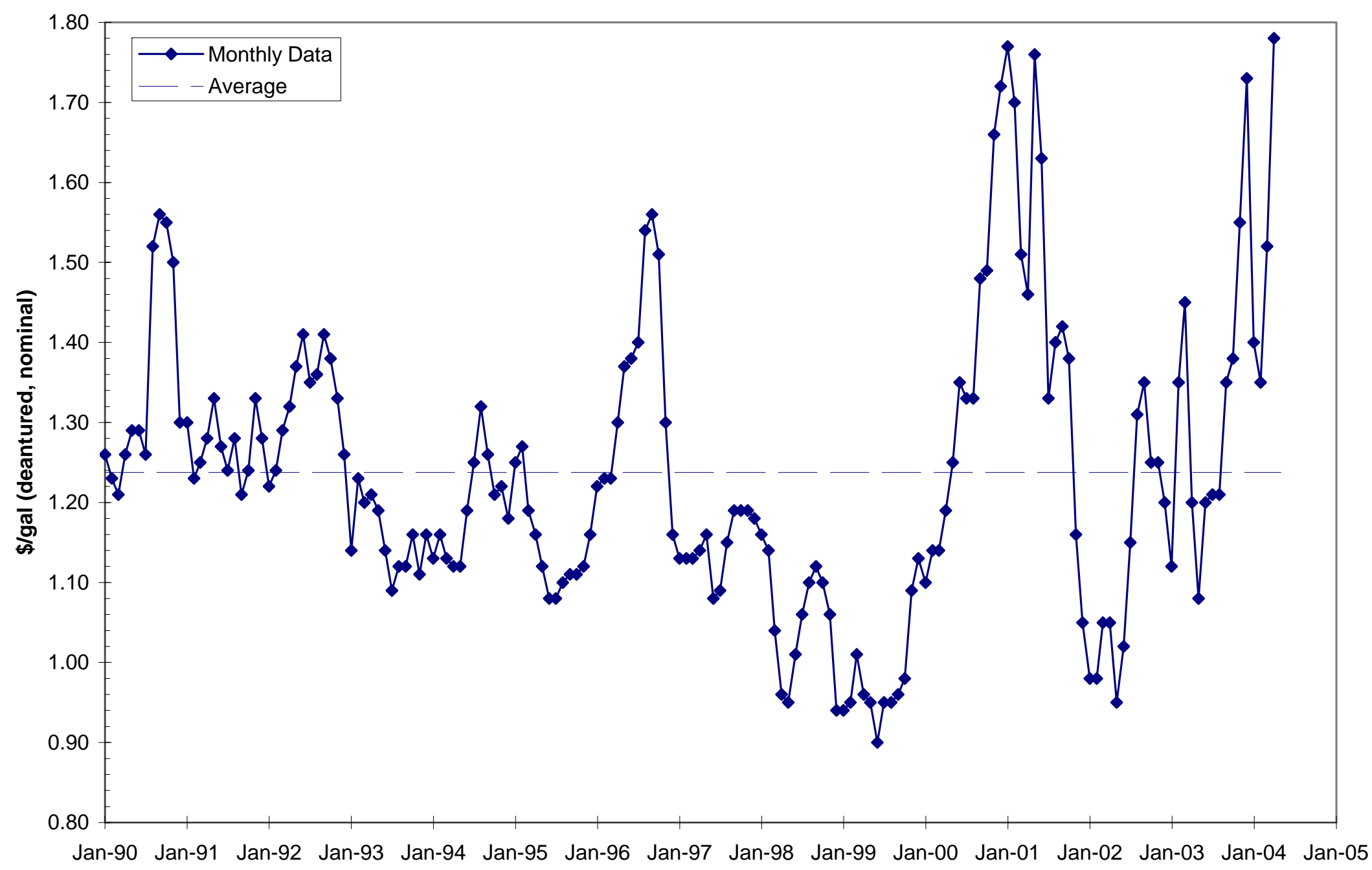




\section{Figure 4 - Cost Breakdown}

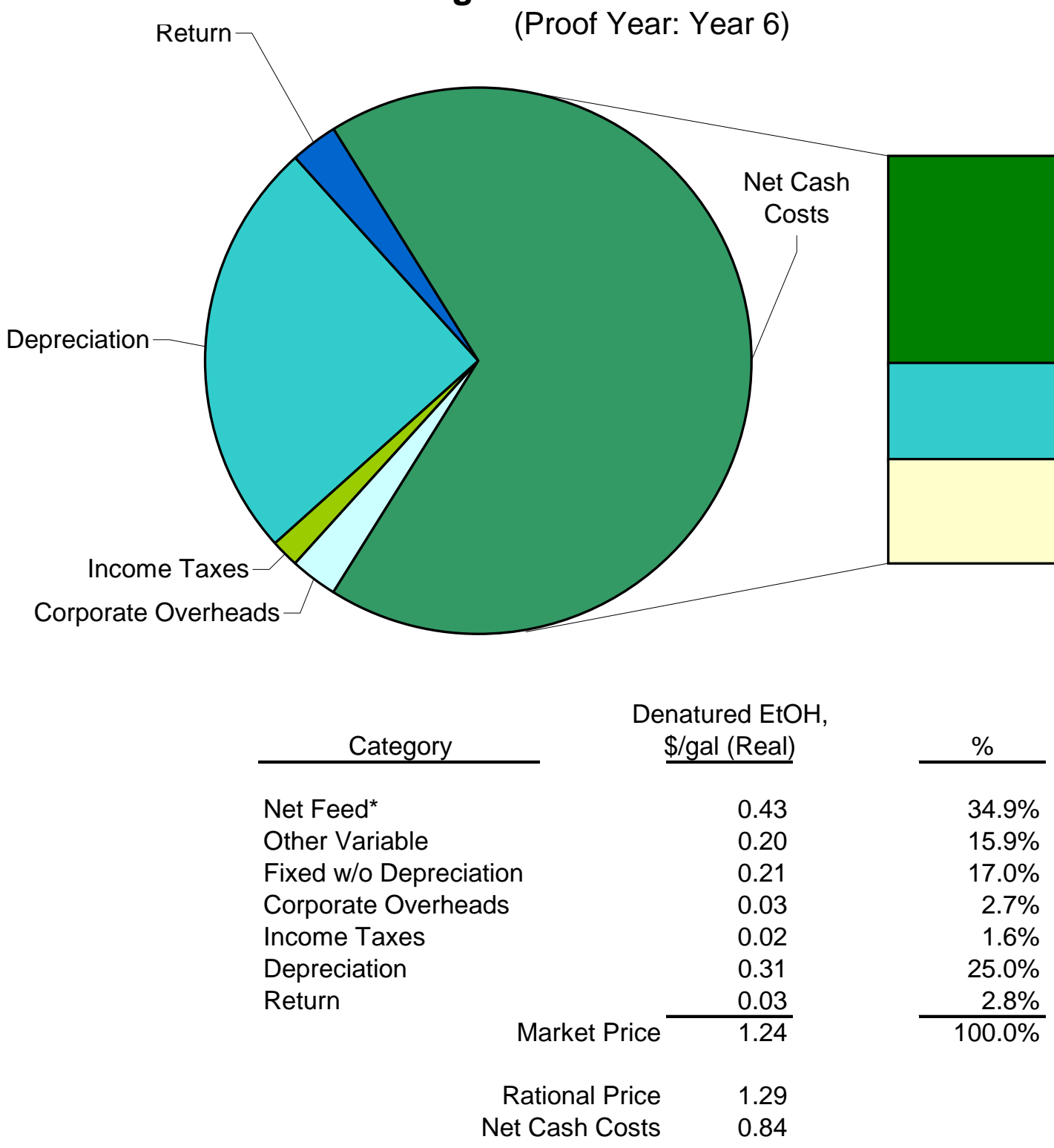

Net Feed*

Other Variable

Fixed w/o Depreciation

${ }^{*}$ Cost of Starch Hydrolyzate+Stover+Light Steep Water Less Revenues from Electricity+5eeep Water Return 
Figure 5 - Sensitivity wrt Fixed Capital

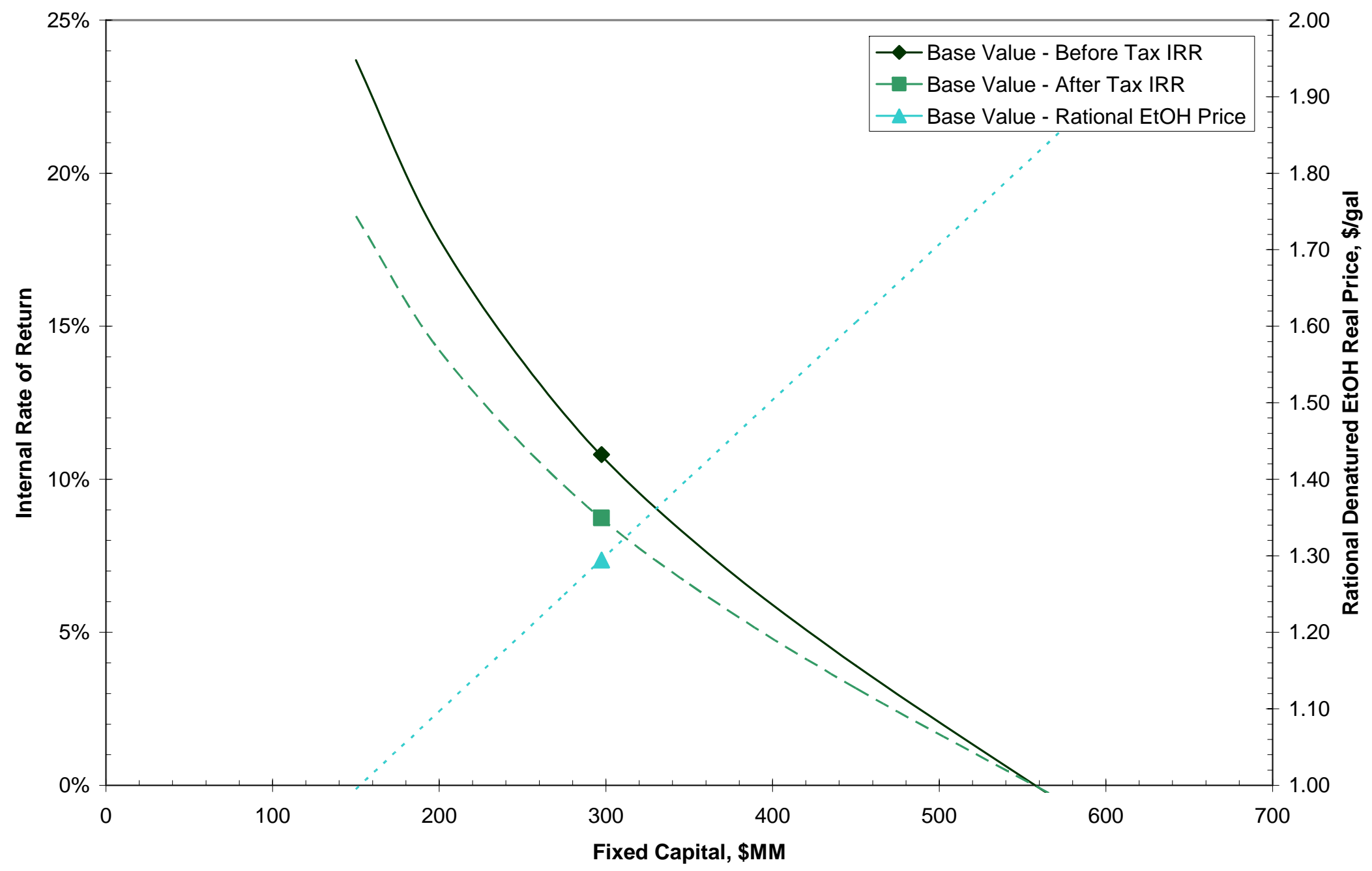


Figure 6 - Sensitivity wrt Starch Hydrolyzate Price

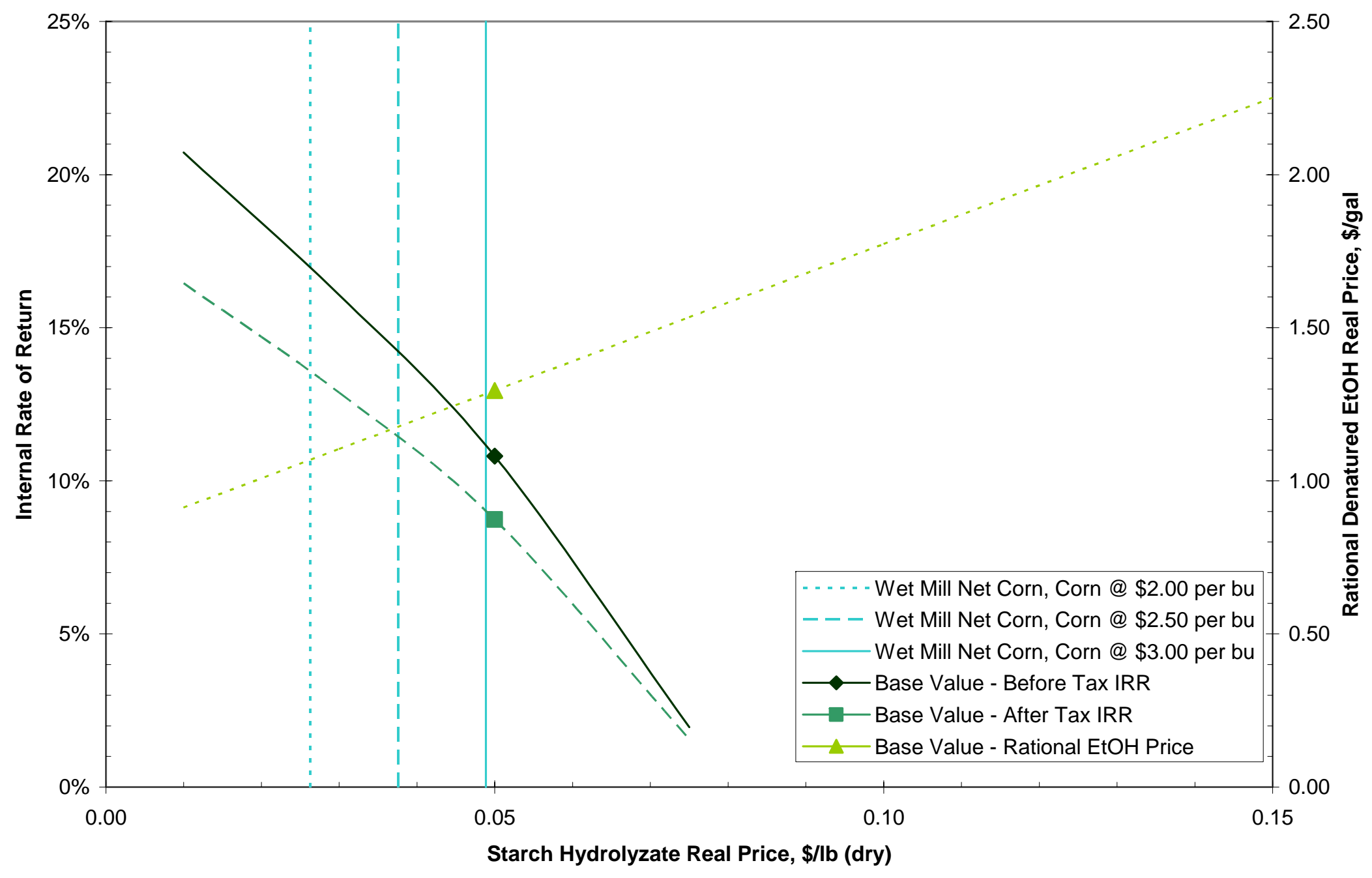


Figure 7 - Sensitivity wrt Stover Price

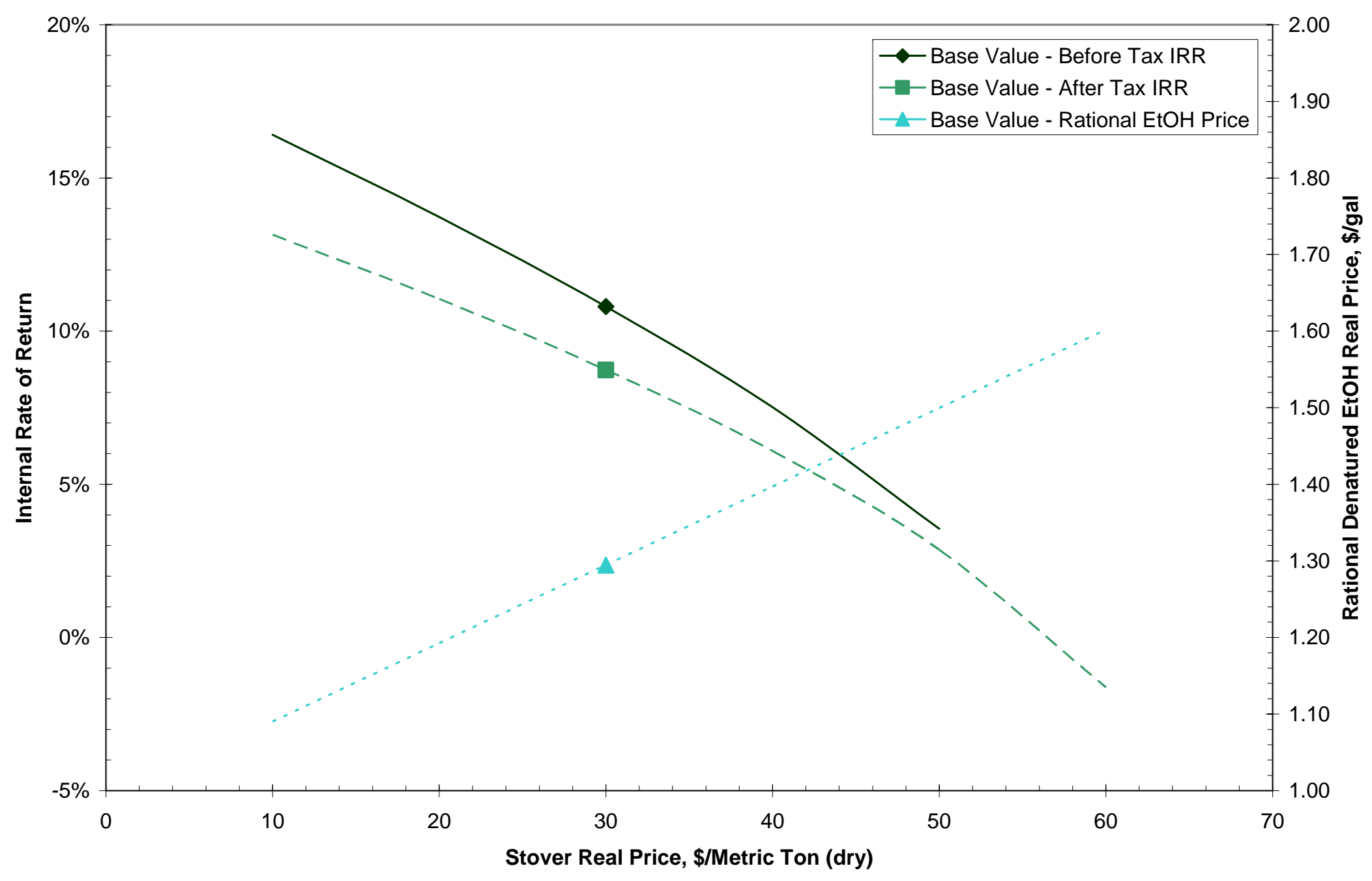


Figure 8 - Sensitivity wrt Denatured EtOH Price

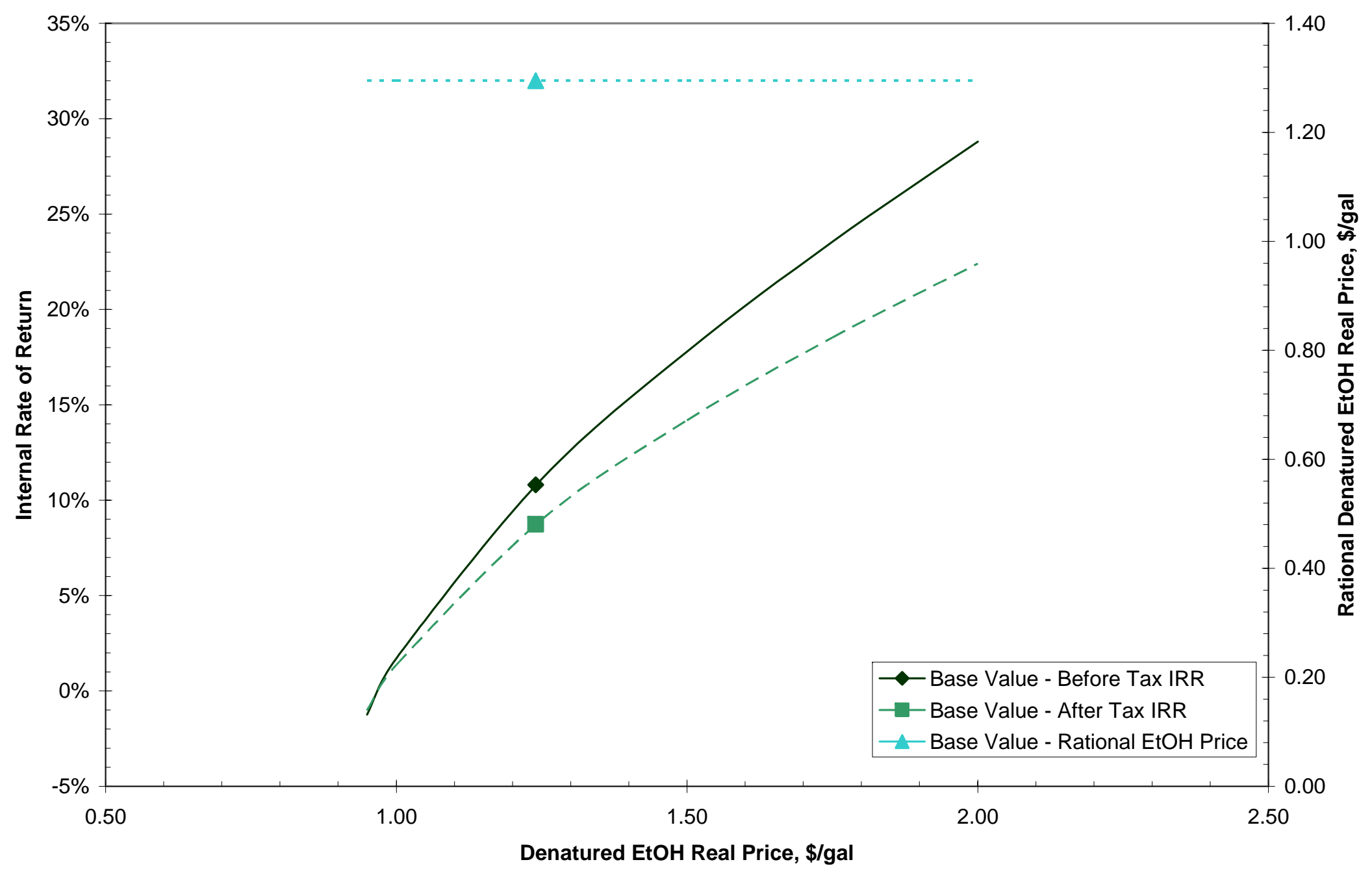


Figure 9 - Sensitivity wrt Electricity Price

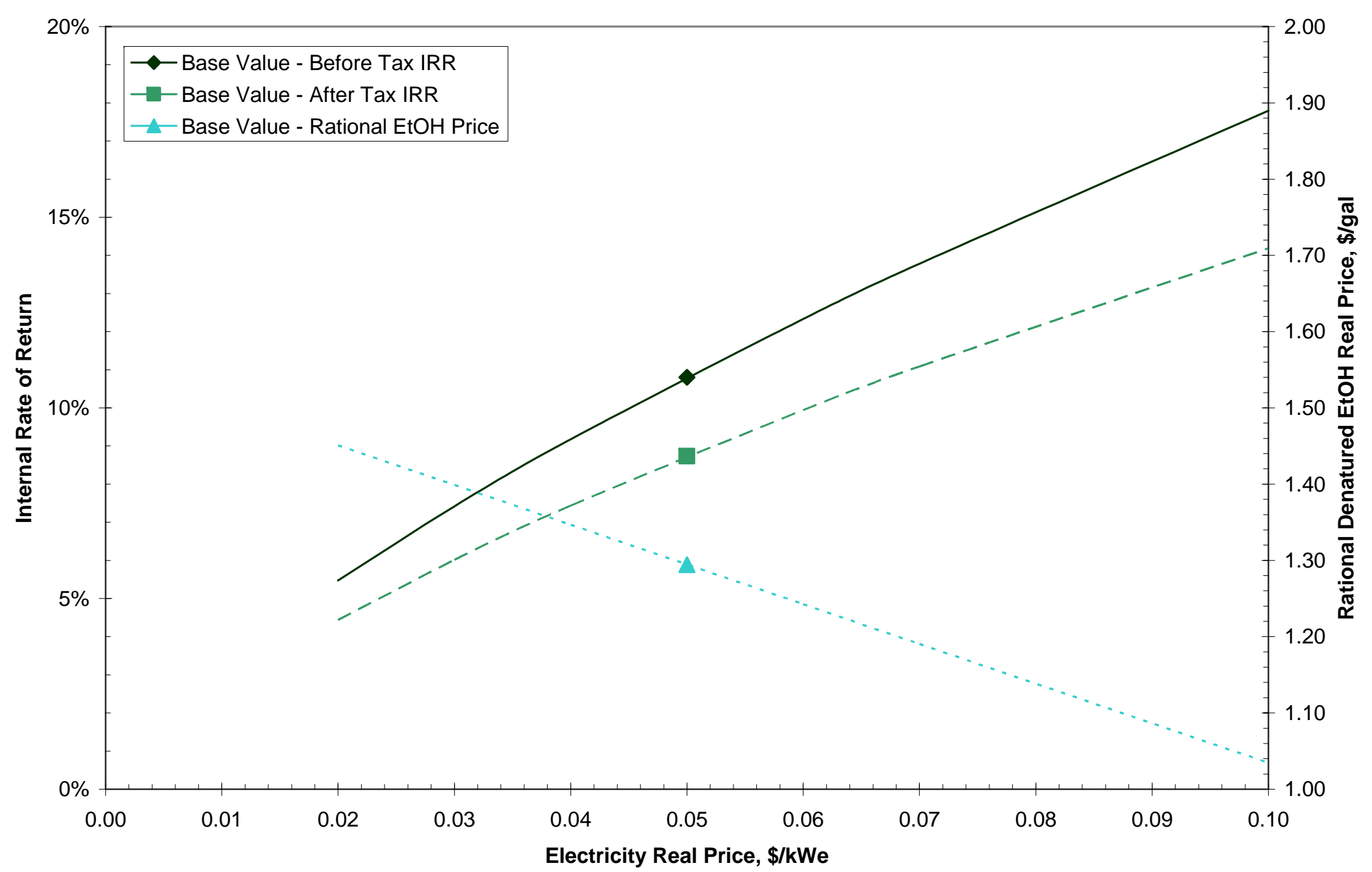


Figure 10 - Sensitivity wrt Steep Water Return Price

(Light Steep Water Price Constant at \$130 per US Ton (dry))

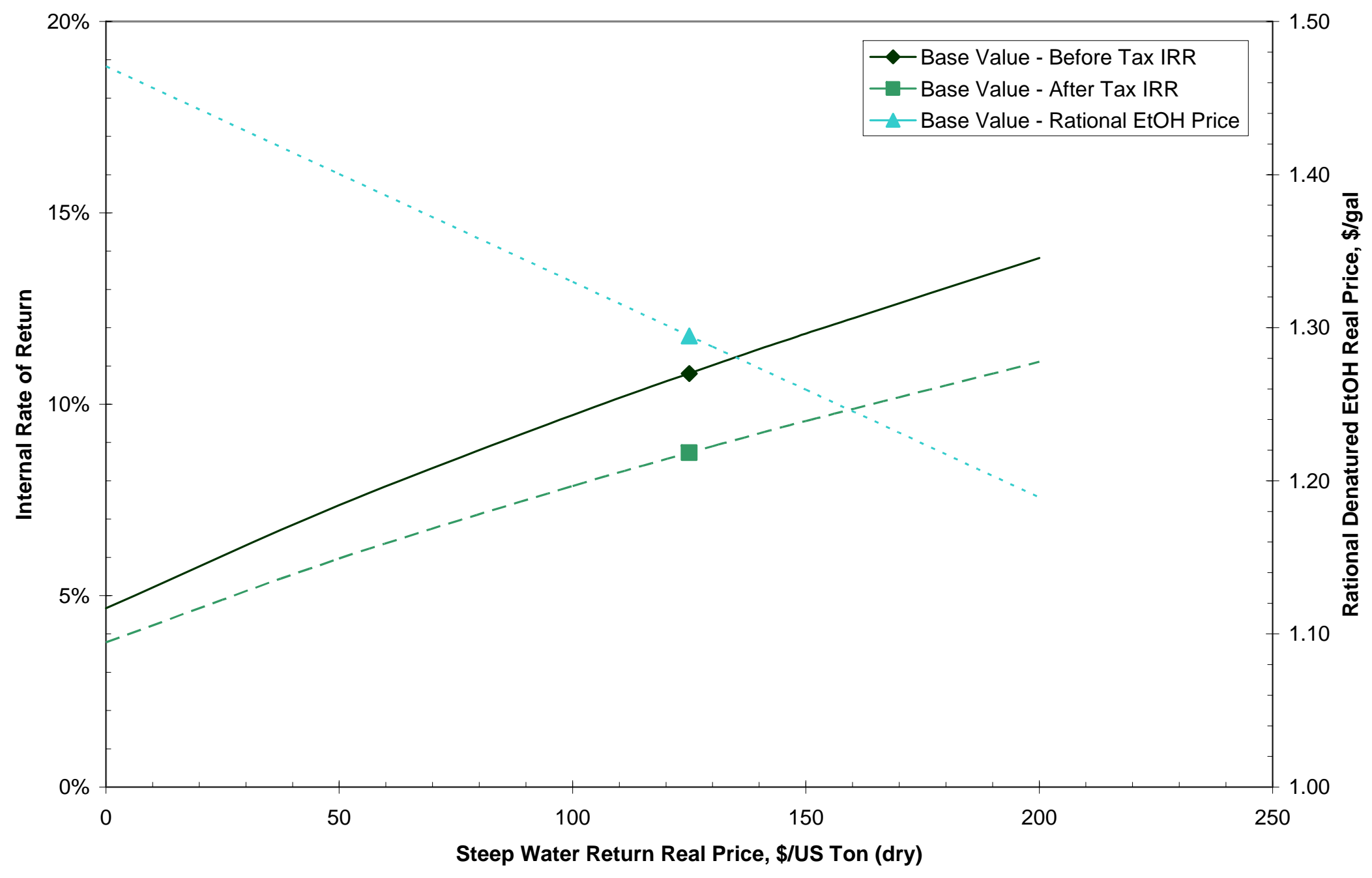




\section{Figure 11 - Sensitivity wrt Discount Rate}

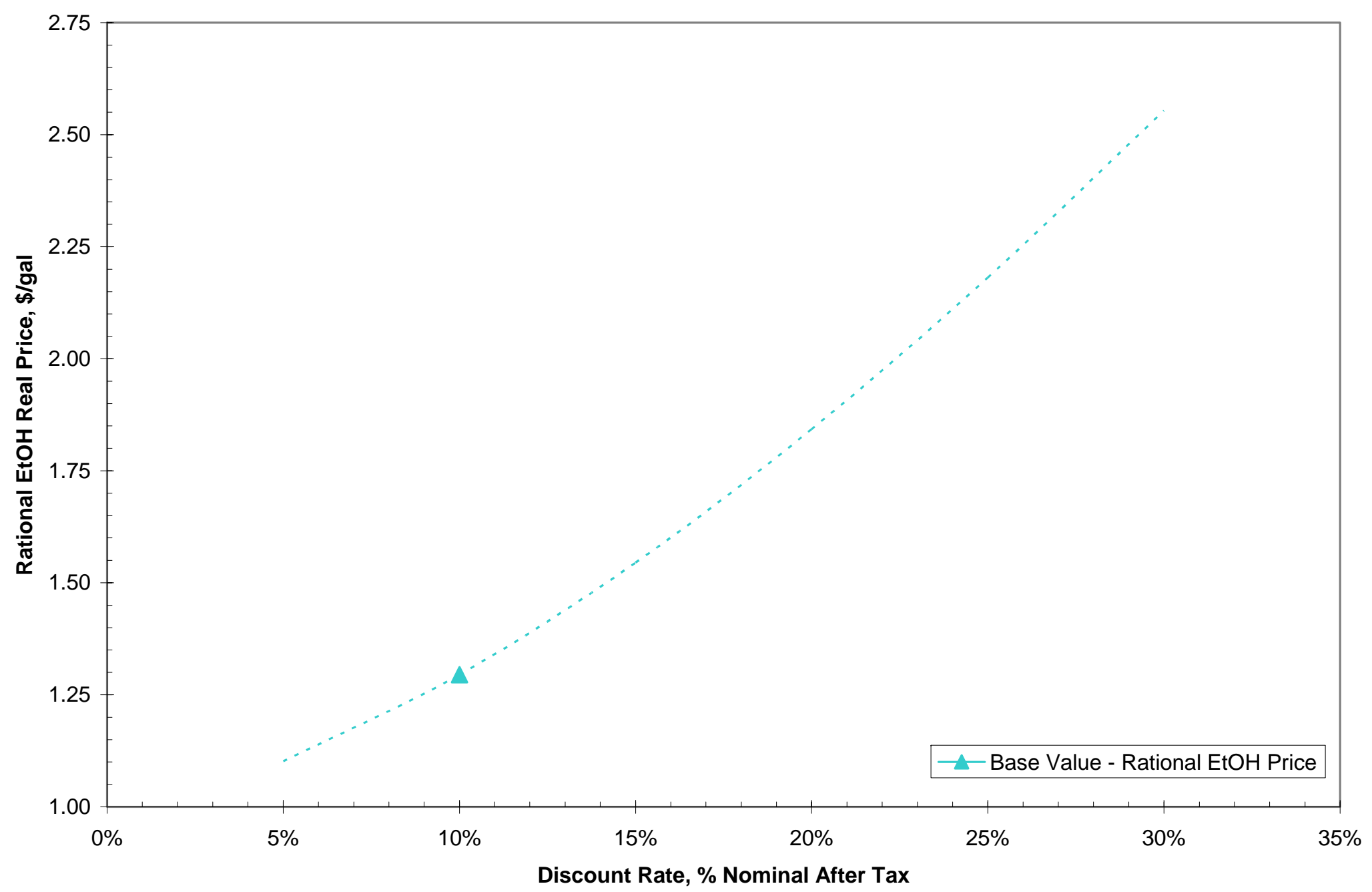




\section{Figure 12 - Monte Carlo Summary}

\section{Monte Carlo Variables}

Operating Rate, Year 3

Operating Rate, Year 4

Operating Rate, other years

\section{Denatured Ethanol}

Electricity Export

Steep Water Return

Fixed Capital

Start-up Costs

Starch Hydrolyzate

Stover

Light Steep Water

Other Variable

Fixed w/o Depreciation

Corporate Overheads

Income Taxes

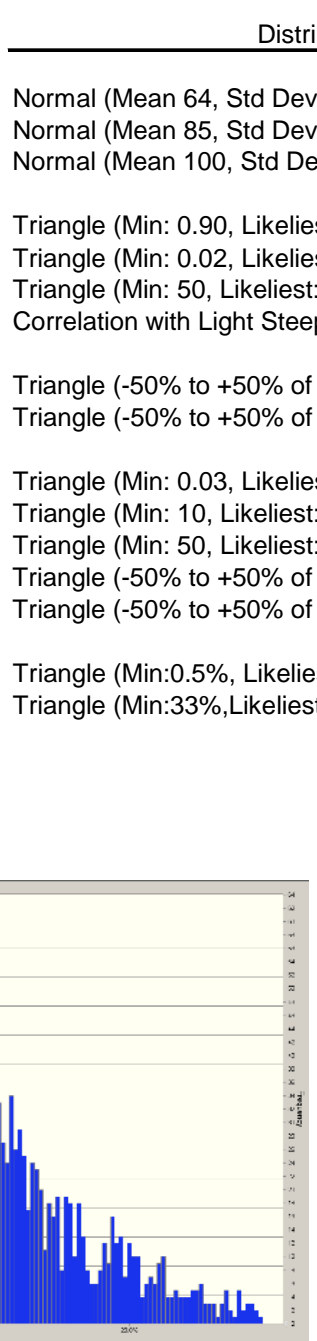

Distribution

Base

Value

64

85

100

1.24

0.05

297.3

14.9

0.0500

30

130

19.77

21.08

2
37
$\%$ of Nameplate $\%$ of Nameplate $\%$ of Nameplate

\$/gal

$\$ / k W$

\$/US Ton (dry)

\$MM

\$MM

$\$ / l b$ (dry)

\$/Metric Ton (dry)

\$/US Ton (dry)

\$MM/yr

$\$ M M / y r$

$\%$ of Revenue

$\%$ Rate

\section{Result Summary}
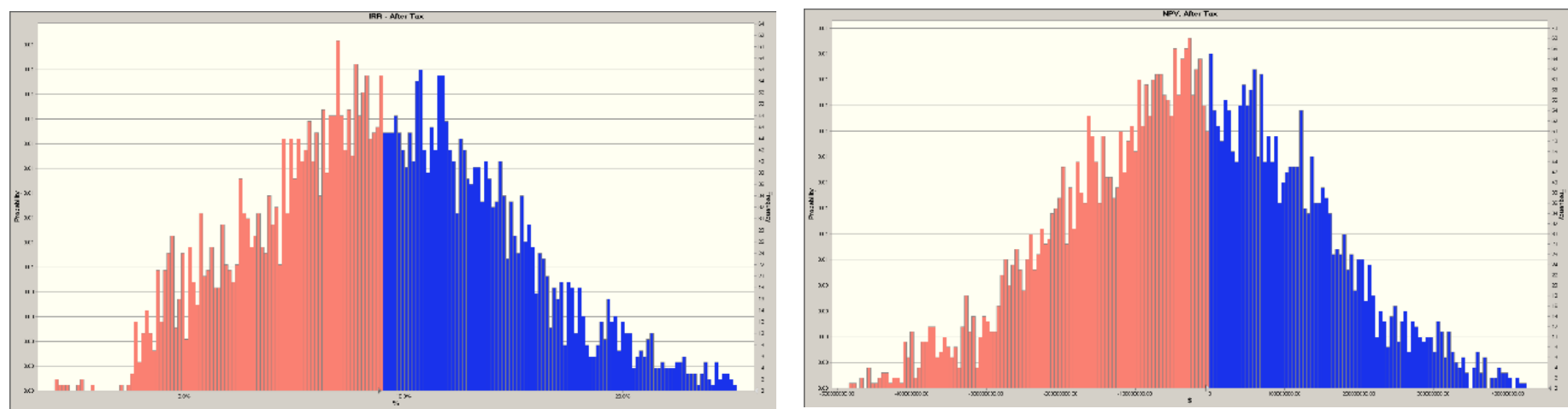